In cooperation with the

New Hampshire Department of Environmental Services and the

U.S. Environmental Protection Agency, Region 1

\title{
Simulation of Solute Transport of Tetrachloroethylene in Ground Water of the Glacial-Drift Aquifer at the Savage Municipal Well Superfund Site, Milford, New Hampshire, 1960-2000
}

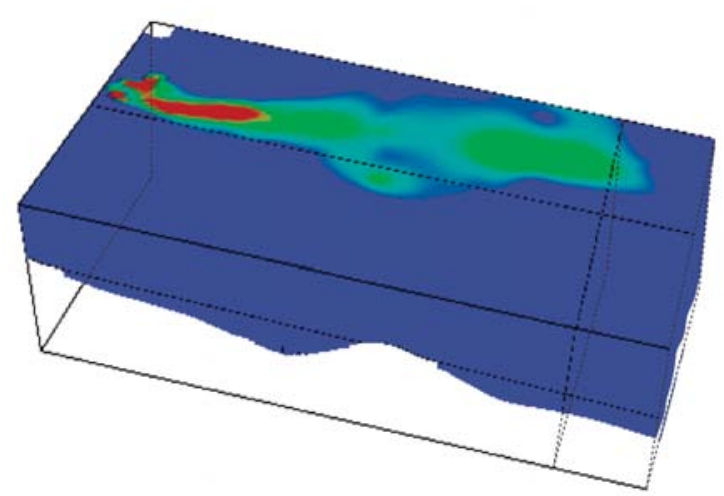

Scientific Investigations Report 2004-5176

U.S. Department of the Interior

U.S. Geological Survey 
Cover-A three-dimensional view of the model-computed tetrachloroethylene (PCE) concentrations from December 1998. The view is from the south looking north and shows the distribution of PCE in the upper aquifer. Areas of highest concentrations (above 1,000 parts per billion) are shown in red, areas of concentrations from 1,000 to 10 parts per billion are shown in light blue to green, and areas of lowest concentrations (less than 10 parts per billion) are shown in dark blue. 
Simulation of Solute Transport of

Tetrachloroethylene in Ground Water

of the Glacial-Drift Aquifer at the

Savage Municipal Well Superfund Site,

Milford, New Hampshire, 1960-2000

By Philip T. Harte

In cooperation with the

New Hampshire Department of Environmental Services, and the

U.S. Environmental Protection Agency, Region 1

Scientific Investigations Report 2004-5176

U.S. Department of the Interior

U.S. Geological Survey 


\title{
U.S. Department of the Interior Gale A. Norton, Secretary
}

\author{
U.S. Geological Survey \\ Charles G. Groat, Director
}

\section{U.S. Geological Survey, Reston, Virginia: 2004}

\author{
For sale by U.S. Geological Survey, Information Services \\ Box 25286, Denver Federal Center \\ Denver, CO 80225 \\ For more information about the USGS and its products: \\ Telephone: 1-888-ASK-USGS \\ World Wide Web: http://www.usgs.gov/
}

\begin{abstract}
Any use of trade, product, or firm names in this publication is for descriptive purposes only and does not imply endorsement by the U.S. Government.

Although this report is in the public domain, permission must be secured from the individual copyright owners to reproduce any copyrighted materials contained within this report.
\end{abstract}

Suggested citation:

Harte, P.T., 2004, Simulation of source transport of tetrachloroethylene in ground water of the glacial-drift aquifer at the Savage Municipal Well Superfund site, Milford, New Hampshire, 1960-2000: Scientific Investigations Report 2004$5176,78 p$. 


\section{Contents}

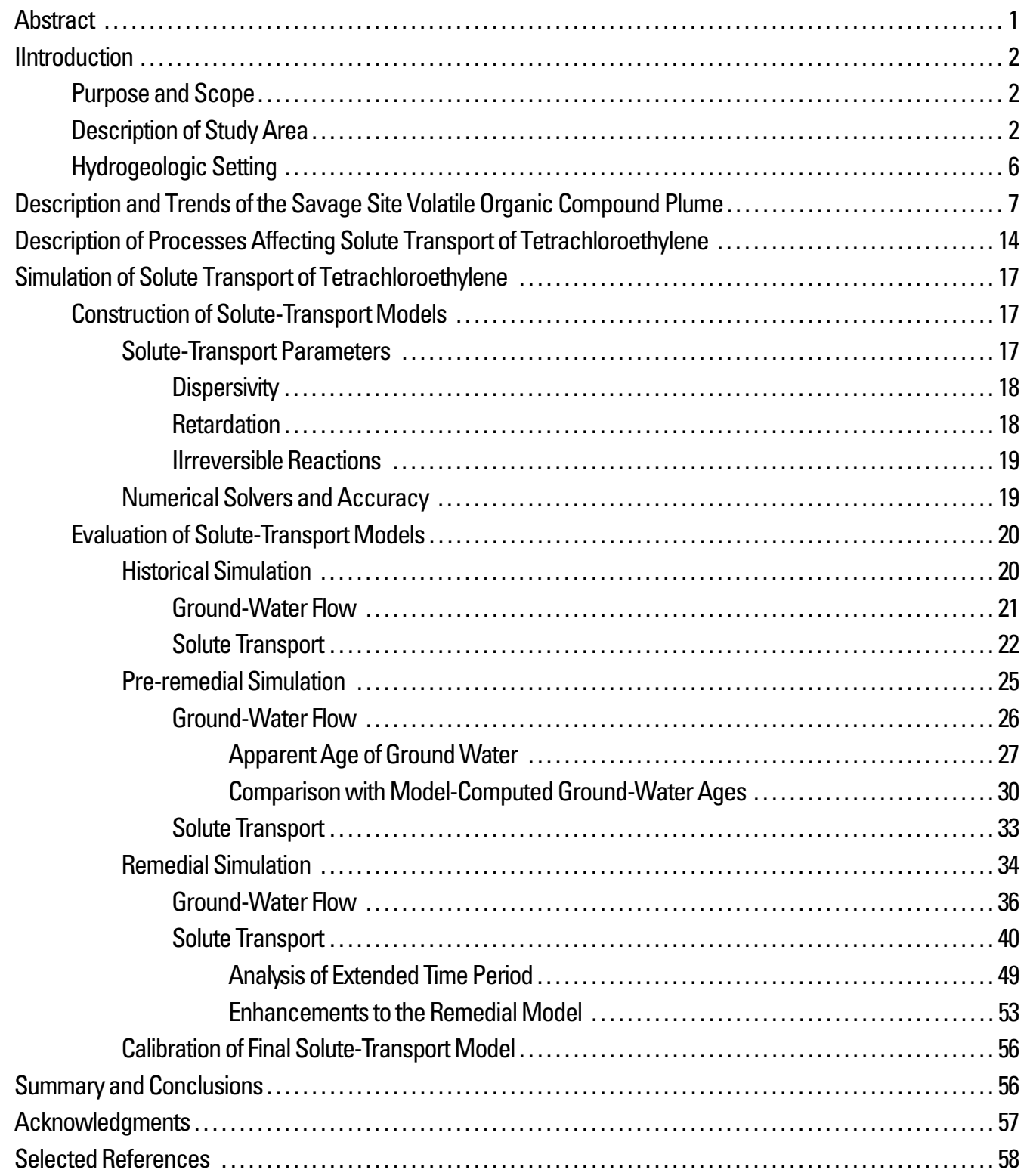

\section{Plates (folded in back of report)}

\section{1-4. Maps Showing -}

1. Locations of ground-water wells, test borings, stream-gaging stations, and subbasins in the Milford-Souhegan Glacial-Drift aquifer, Milford, N.H.

2. Locations of ground-water wells, test borings, air sparge, and vapor extraction wells for Operable Unit\#1 (OU1) of the Savage Municipal Well Superfund site, Milford, N.H.

3. Locations of vertical profile points and selected ground-water wells in the Milford-Souhegan Glacial-Drift aquifer, Milford, N.H.

4. Numerical finite-difference grid for ground-water flow and the extent of subgrids for solute transport in the western part of the Milford-Souhegan Glacial-Drift aquifer, Milford, N.H. 


\section{Figures}

1-5. Maps showing-

1. Location of the Milford-Souhegan glacial-drift aquifer, Savage well, and operable units 1 (OU1) and 2 (OU2) of the Savage Municipal Well Superfund site, Milford, N.H. ........ 3

2. (A) Location of contaminant plume in 1989 of volatile organic compounds and (B) ground-water-head contours in 1994 in the Milford-Souhegan glacial-drift aquifer, Savage Municipal Well Superfund site, Milford, N.H. ............................

3. Remedial system, tetrachloroethylene (PCE) concentrations, and monitoring wells in the OK Tool facility (OU1) of the Savage Municipal Well Superfund site, Milford, N.H. ..........5

4. Contours of maximum tetrachloroethylene (PCE) concentrations in (A) 1989, and (B) 1994, in the Savage Municipal Well Superfund site, Milford, N.H.

5. Contours of maximum tetrachloroethylene (PCE) concentrations in 1995 and graphs of PCE concentrations for selected wells, Savage Well Municipal Superfund site, Milford, N.H.

6. Diagram showing generalized cross section of model layers, major hydrologic boundaries, and lithology.

7-8. Maps showing -

7. Contours of mean tetrachloroethylene (PCE) concentrations in model layers (A) 1 and

(B) 2 as of 1995, Savage Municipal Well Superfund site, Milford, N.H. . .

8. Contours of mean tetrachloroethylene (PCE) concentrations in model layers (A) 3 and

(B) 4 as of 1995, Savage Municipal Well Superfund site, Milford, N.H. . .

9. Graph showing rate of mass input of tetrachloroethylene (PCE) in OU1 in relation to the mean concentration of model-computed PCE concentrations from three locations in OU1,

Savage Municipal Well Superfund site, Milford, N.H.

10-13. Maps showing -

10. Contours of tetrachloroethylene (PCE) concentrations through time from two-dimensional model for (A) starting conditions in 1960, (B) 1965, (C) 1974, (D) 1983, and (E) 1989,

Savage Municipal Well Superfund site, Milford, N.H.

11. Contours of 1,000 parts per billion (ppb) tetrachloroethylene (PCE) concentrations from observation and multiple simulations using the two-dimensional model, 1989,

Savage Municipal Well Superfund site, Milford, N.H.

12. Head residuals (differences) between model-computed heads from steady-state simulation of 1995-98 conditions and observed heads from December 1998 for model layer 3, Milford-Souhegan glacial-drift aquifer, Savage Municipal Well Superfund site, Milford, N.H.....

13. Contours of model-computed heads from steady-state simulation of 1995-98 conditions for model layer 3, Milford-Souhegan glacial-drift aquifer, Savage Municipal Well Superfund site, Milford, N.H.

14-16. Graphs showing -

14. Comparison of model-computed ages in relation to apparent ages for (A) wells B95-6 and (B) B95-3 showing discrete ages of individual particles and mean age per model layer from simulation of 1995-98 steady-state conditions and apparent age from tritium-helium concentrations in May 1997 samples, Milford-Souhegan glacial-drift aquifer, in the OU1 part of the Savage Municipal Well Superfund site, Milford, N.H. ...

15. Comparison of model-computed and observed tetrachloroethylene (PCE) concentrations, December 1998, in the OU1 part of the Savage Municipal Well Superfund site, Milford, N.H.

16. Model-computed and observed heads from April to September 1999 for well PW-1D, Milford-Souhegan glacial-drift aquifer, in the OU1 part of the Savage Municipal Well Superfund site, Milford, N.H. 
17-18. Maps showing-

17. Contours of model-computed heads from remedial simulation and observed heads, August 1999, for model layer 4, Milford-Souhegan glacial-drift aquifer, in the OU1 part of the Savage Municipal Well Superfund site, Milford, N.H. . ...

18. Contours of model-computed heads from remedial simulation and observed heads, September 1999, for model layer 4, Milford-Souhegan glacial-drift aquifer, in the OU1 part of the Savage Municipal Well Superfund site, Milford, N.H. . . .

19-23. Graphs showing -

19. Simulated ground-water-flow budget for (A) August 1999 and for (B) September 1999, Milford-Souhegan glacial-drift aquifer, Savage Municipal Well Superfund site, Milford, N.H. ...

20. Model-computed tetrachloroethylene (PCE) concentrations and observed concentrations for PCE, trichloroethylene (TCE), and cis-1,2-dichloroethylene (cis-DCE) for wells (A) B95-13, and (B) PW-13M in the OU1 part of the Savage Municipal Well Superfund site, Milford, N.H.

21. Model-computed tetrachloroethylene (PCE) concentrations and observed concentrations for PCE, trichloroethylene (TCE), and cis-1,2-dichloroethylene (cis-DCE) for wells (A) PW-14M, and (B) MW-16B in the OU1 part of the Savage Municipal Well Superfund site, Milford, N.H. . ...

22. Model-computed tetrachloroethylene (PCE) concentrations and observed concentrations for PCE, trichloroethylene (TCE), and cis-1,2-dichloroethylene (cis-DCE) for wells (A) MW-20B, and (B) MW-11B in the OU2 part of the Savage Municipal Well Superfund site, Milford, N.H. . ...

23. Model-computed tetrachloroethylene (PCE) concentrations and observed concentrations for PCE, trichloroethylene (TCE), and cis-1,2-dichloroethylene (cis-DCE) for wells (A) MW-14A, and (B) MW-101C in the OU2 part of the Savage Municipal Well Superfund site, Milford, N.H.

24. Maps showing model-computed tetrachloroethylene (PCE) concentrations for layer 3 for (A) December 1998, and for (B) May 2000 in the 0 U1 part of the Savage Municipal Well Superfund site, Milford, N.H.

\section{Tables}

1. Summary of PCE and TCE concentrations in samples collected between 1994 and December 1998 for commonly sampled wells at the Savage Municipal Well Superfund site, Milford, N.H. 13

2. Summary of PCE and TCE concentrations in samples collected in 1994, December 1998, and May 1999 for commonly sampled wells at the Savage Municipal Well Superfund site, Milford, N.H. 13

3. Summary of physical and chemical characteristics of select volatile organic compound plumes in North America.

4. Results of two-dimensional and three-dimensional steady-state models (ground-water-flow budgets, head residuals, travel times from advective transport and river seepage) Savage Municipal Well Superfund site, Milford, N.H.

5. Summary of mass inputs of tetrachloroethylene (PCE) for simulated historical runs that test the effects of mass loads of PCE on computed concentrations in the OU1 part of the Savage Municipal Well Superfund site, Milford, N.H.

6. Information on wells sampled in May 1997 for tritium-helium isotope and tritium-helium concentrations, Milford-Souhegan Glacial-Drift aquifer in the OU1 part of the Savage Municipal Well Superfund site, Milford, N.H. 
7. Rates of extraction and injection for remedial wells in OU1 as reported in May 1999, Savage Municipal Well Superfund site, Milford, N.H.

8. Differences between model-computed tetrachloroethylene (PCE) concentrations and observed PCE concentrations for September 1999 in OU1, Savage Municipal Well Superfund Site, Milford, N.H.

9. Differences between model-computed tetrachloroethylene (PCE) concentrations and observed PCE concentrations for September 1999 in OU2, Savage Municipal Well Superfund Site, Milford, N.H.

10. Differences between model-computed tetrachloroethylene (PCE) concentrations and observed PCE concentrations for May 2000 in 0U1, Savage Municipal Well Superfund Site, Milford, N.H.

11. Differences between model-computed tetrachloroethylene (PCE) concentrations and observed PCE concentrations for June 2000 in OU2, Savage Municipal Well Superfund Site, Milford, N.H.

12. Differences between model-computed tetrachloroethylene (PCE) concentrations and observed PCE concentrations for September 1999 in OU1, Savage Municipal Well Superfund Site, Milford, N.H.

\section{Appendixes 1-4b.}

1. Information on wells and vertical profile points, Savage Municipal Well Superfund Site, Milford, N.H. ....

2. Information on historical withdrawals from pre-1960 to December 1988, and simulated stress periods for historical calibration, Savage Municipal Well Superfund Site, Milford, N.H.

3. Summary of selected model runs for historical, pre-remedial, and remedial simulations, Savage Municipal Well Superfund site, Milford, N.H.

4a. Summary of model-computed ages from discrete particles backward tracked from screen interval layer(s), steady-state simulation of 1995-98 conditions, Milford-Souhegan glacial-drift aquifer, Milford, N.H.

4b. Summary of model-computed ages from discrete particles backward tracked from sample intake layer, steady-state simulation of 1995-98 conditions, Milford-Souhegan glacial-drift aquifer, Milford, N.H. 


\section{Conversion Factors, Datums, Acronyms, and} Abbreviations

\begin{tabular}{|c|c|c|}
\hline Multiply & By & To obtain \\
\hline \multicolumn{3}{|c|}{ Length } \\
\hline inch (in.) & 25.4 & millimeter $(\mathrm{mm})$ \\
\hline foot $(\mathrm{ft})$ & 0.3048 & meter $(\mathrm{m})$ \\
\hline mile (mi) & 1.609 & kilometer (km) \\
\hline \multicolumn{3}{|c|}{ Area } \\
\hline square mile $\left(\mathrm{mi}^{2}\right)$ & 2.590 & square kilometer $\left(\mathrm{km}^{2}\right)$ \\
\hline \multicolumn{3}{|c|}{ Volume } \\
\hline cubic inch $\left(\right.$ in $\left.^{3}\right)$ & 16.39 & cubic centimeter $\left(\mathrm{cm}^{3}\right)$ \\
\hline cubic inch $\left(i^{3}\right)$ & 16.39 & milliliter $(\mathrm{mL})$ \\
\hline gallon (gal) & 3.785 & liter $(\mathrm{L})$ \\
\hline cubic foot $\left(\mathrm{ft}^{3}\right)$ & 0.02832 & cubic meter $\left(\mathrm{m}^{3}\right)$ \\
\hline \multicolumn{3}{|c|}{ Mass } \\
\hline ounce (oz) & 28.35 & gram $(\mathrm{g})$ \\
\hline \multicolumn{3}{|c|}{ Flow rate } \\
\hline cubic foot per second $\left(\mathrm{ft}^{3} / \mathrm{s}\right)$ & 0.02832 & cubic meter per second $\left(\mathrm{m}^{3} / \mathrm{s}\right)$ \\
\hline gallon per minute (gal/min) & 0.06309 & liter per second $(\mathrm{L} / \mathrm{s})$ \\
\hline million gallons per day $(\mathrm{Mgal} / \mathrm{d})$ & 0.04381 & cubic meter per second $\left(\mathrm{m}^{3} / \mathrm{s}\right)$ \\
\hline million gallons per day (Mgal/d) & 1.547 & cubic feet per second $\left(\mathrm{ft}^{3} / \mathrm{s}\right)$ \\
\hline inch per year (in/yr) & 25.4 & millimeter per year $(\mathrm{mm} / \mathrm{yr})$ \\
\hline \multicolumn{3}{|c|}{ Hydraulic conductivity } \\
\hline foot per day (ft/d) & 0.3048 & meter per day $(\mathrm{m} / \mathrm{d})$ \\
\hline
\end{tabular}

Vertical coordinate information is referenced to the National Geodetic Vertical Datum of 1929 (NGVD of 1929) — a geodetic datum derived from a general adjustment of the first-order level nets of both the United States and Canada, formerly called Sea Level Datum of 1929.

Horizontal coordinate information is referenced to the North American Datum of 1983 (NAD83).

Concentrations of chemical constituents in water are given either in milligrams per liter $(\mathrm{mg} / \mathrm{L})$ [parts per million (ppm)] or micrograms per liter ( $\mu \mathrm{g} / \mathrm{L})$ [parts per billion ( $\mathrm{ppb})$ ].

NOTE: Megagram $(\mathrm{Mg})$ is $1,000,000$ grams. 


\begin{tabular}{|c|c|}
\hline CFC & chlorofluorocarbon \\
\hline cis-1,2-DCE & cis-1,2-dichloroethene \\
\hline DCE & dichloroethene \\
\hline 1,2-DCE & 1,2-dichloroethene \\
\hline DNAPL'S & Dense №n-Aqqueous $\underline{P}$ hase Liquids \\
\hline$f_{o c}$ & organic carbon content \\
\hline $\mathrm{H}^{3}$ & Tritium \\
\hline $\mathrm{He}$ & Helium \\
\hline${ }^{4} \mathrm{He}$ & Helium-4 \\
\hline MSGD & Milford-Souhegan Glacial-Drift aquifer \\
\hline MTBE & methyl tert-butyl ether \\
\hline NTU & neophelometric turbidity units \\
\hline OU1 & Operable Unit \#1 of the Savage Municipal Well Superfund Site \\
\hline OU2 & Operable Unit \#2 of the Savage Municipal Well Superfund Site \\
\hline PCA & 1,1,2,2-tetrachloroethane \\
\hline PCE & tetrachloroethylene \\
\hline PVC & polyvinyl chloride \\
\hline$R_{f}$ or $R$ & Retardation factor or coefficient \\
\hline$R^{2}$ & coefficient of determination \\
\hline RMSE & Root mean square error \\
\hline TCA & trichloroethane \\
\hline TCE & trichloroethylene \\
\hline TOC & total organic carbon \\
\hline trans-1,2-DCE & trans-1,2-dichloroethene \\
\hline VC & vinyl chloride \\
\hline VOC & volatile organic compound \\
\hline $2-d$ & two-dimensional \\
\hline $3-d$ & three-dimensional \\
\hline
\end{tabular}


UNITS OF MEASUREMENT

$\begin{array}{ll}\mathrm{CCSTPg}^{-1} & \text { cubic centimeter at standard temperatures and pressures } \\ \mathrm{cm}^{3} / \mathrm{gm} & \text { cubic centimeter per gram } \\ \mathrm{g} & \text { grams } \\ \mathrm{g} / \mathrm{cm}^{3} & \text { gram per cubic centimeter } \\ \mathrm{g} / \mathrm{min} & \text { gram per minute } \\ \mathrm{g} / \mathrm{yr} & \text { gram per year } \\ \mathrm{in} / \mathrm{mo} & \text { inch per month } \\ \mathrm{L} / \mathrm{min} & \text { liter per minute } \\ \mathrm{mFg} & \text { million grams } \\ \mathrm{mg} / \mathrm{s} & \text { milligram per second } \\ \mathrm{Mg} / \mathrm{yr} & \text { megagram per year } \\ \mathrm{min} & \text { minute } \\ \mathrm{mL} & \text { milliliter } \\ \mathrm{yr} & \text { year }\end{array}$

\section{WELL IDENTIFICATION, ABBREVIATIONS, AND EXPLANATION}

Well names used in this report, including appendix 1, are typically designated based on previous studies. In some cases, well names are designated after the owner's name.

\section{Prefix for remedial wells}

EW

exterior barrier wall extraction well

IW

interior barrier wall extraction well

RW

recharge wells

SP

air sparge well (used for remedial technology that reduces concentrations of volatile contaminants adsorbed to soils and dissolved in ground water in the saturated zone; involves the injection of air into the saturated zone)

SVE soil vapor extraction well (used for remedial technology that reduces concentrations of volatile contaminants adsorbed to soils in the unsaturated zone; involves the extraction of air from the unsaturated zone) 
Prefix for observation wells

P piezometer

PW, B, MI, and MW observation wells

Suffix for observation wells

D or C deep cluster well

$\mathrm{M}$ or $\mathrm{B} \quad$ medium cluster well

R bedrock well

S or A shallow cluster well

Lithology abbreviations

coarse

f fine

m medium

Wx weathered

Statistical functions used in this report

Standard Mean Error $=\frac{1}{n} \Sigma\left(h_{m}-h_{o}\right)$

Absolute Mean Error $=\frac{1}{n} \Sigma\left|h_{m}-h_{o}\right|$

where $\quad h_{m} \quad=$ model-computed head,

$h_{o}=$ observed head, and

$n \quad=$ number of observations

Relative concentration $=C / C_{0}$,

where $\quad C=$ concentration at reported time, and

$C / C_{o}=$ initial concentration at referenced time. 


\title{
Simulation of Solute Transport of Tetrachloroethylene in Ground Water of the Glacial-Drift Aquifer at the Savage Municipal Well Superfund Site, Milford, New Hampshire, 1960-2000
}

\author{
By Philip T. Harte
}

\section{Abstract}

The Savage Municipal Well Superfund site, named after the former municipal water-supply well for the town of Milford, is underlain by a 0.5 -square mile plume of volatile organic compounds (VOCs), primarily tetrachloroethylene (PCE). The plume occurs mostly within a highly transmissive sand-andgravel unit, but also extends to an underlying till and bedrock unit. The plume logistically is divided into two areas termed Operable Unit No. 1 (OU1), which contains the primary source area, and Operable Unit No. 2 (OU2), which is the extended plume area.

PCE concentrations in excess of 100,000 parts per billion (ppb) had been detected in the OU1 area in 1995, indicating a likely Dense Non-Aqueous Phase Liquid (DNAPL) source. In the fall of 1998, the New Hampshire Department of Environmental Services (NHDES) and the U.S. Environmental Protection Agency (USEPA) installed a remedial system in OU1. The OU1 remedial system includes a low-permeability barrier that encircles the highest detected concentrations of PCE, and a series of injection and extraction wells. The barrier primarily sits atop bedrock and penetrates the full thickness of the sand and gravel; and in some places, the full thickness of the underlying basal till. The sand and gravel unit and the till comprise the aquifer termed the Milford-Souhegan glacial-drift aquifer (MSGD).

Two-dimensional and three-dimensional finite-difference solute-transport models of the unconsolidated sediments (MSGD aquifer) were constructed to help evaluate solute-transport processes, assess the effectiveness of remedial activities in OU1, and to help design remedial strategies in OU2. The solutetransport models simulate PCE concentrations, and model results were compared to observed concentrations of PCE. Simulations were grouped into the following three time periods: an historical calibration of the distribution of PCE from the initial input (circa 1960) of PCE into the subsurface to the 1990s, a pre-remedial calibration from 1995 to 1998, and a remedial (post-barrier wall) calibration from 1998 to 1999. Model results also were checked against observed PCE concentrations from May and June 2000 as a post-audit of model performance.

Results of the simulations of the two-dimensional model for the historical calibration indicate that the model-computed length of the plume is affected by the retardation factor (retardation). Values of retardation greater than 3 caused the longitudinal length of the computed plume to be too short compared to the observed plume. A retardation of 2-2.5 produced a reasonable comparison between computed and observed PCE concentrations. Testing of different starting times and rates of mass input of PCE indicated that the plume reaches a quasi steadystate distribution in about 20 years regardless of the rate of mass input or values of the solute-transport parameters (retardation, dispersion, and irreversible reaction) assigned the model.

Results of the simulations of the three-dimensional model for the pre-remedial (1995-98) calibration of PCE for the OU2 area identified some spatial biases in computed concentrations that generally were unaffected by changes in retardation. The computed PCE concentrations exceeded observed concentrations along the northern part of the plume in OU2, where PCE increases were observed in a bedrock well. These results indicate that some PCE in this area may be entering the bedrock, which is not simulated in the model. Conversely, computed PCE concentrations were less than observed concentrations along the southern part of the plume in OU2. Because testing of high (above 4) values of retardation did little to reduce residuals, it is concluded that the low computed PCE concentrations along the southern flank are likely the result of an underestimation of the initial PCE mass in this area or an unaccounted source of PCE.

Results of the simulations of the three-dimensional model for the remedial calibration period (1998-99) and post-audit period (May-June 2000) showed a decline in concentration at the OU1/OU2 boundary comparable to that observed in the field. In September 1999, computed PCE concentrations decreased by 6 percent from initial concentrations in December 1998, and observed PCE concentrations decreased by 10 percent. In May 2000, decreases were 26 and 29 percent from initial concentrations for computed and observed PCE, respectively. 


\section{Solute Transport of Tetrachloroethylene in Ground Water of the Glacial-Drift Aquifer at the Savage Well Site, Milford, N.H.}

\section{Introduction}

The Savage Municipal Well Superfund site (Savage site), named after the former municipal water-supply well (the Savage well) for the town of Milford, N.H., is underlain by a $0.5-\mathrm{mi}^{2}$ plume of volatile organic compounds (VOCs), containing primarily tetrachloroethylene (PCE) (figs. 1 and 2). The VOC plume occurs mostly within a highly transmissive sandand-gravel unit but also extends to an underlying till and bedrock unit. The sand-and-gravel unit, part of the Milford-Souhegan glacial-drift aquifer (MSGD), is an important source of water for a New Hampshire State Fish Hatchery, supplying more than $2 \mathrm{Mgal} / \mathrm{d}$. Before contamination, the aquifer also supplied more than $1 \mathrm{Mgal} / \mathrm{d}$ to two municipal water-supply wells (the Savage well and a well outside of the study area); however, use of these wells was discontinued because of high levels of VOCs.

A discontinued tool manufacturing facility, the OK Tool facility (also called Operable Unit No. 1 (OU1)), has been identified as the primary source (HMM Associates, Inc., 1989, 1991) of PCE that lead to the contamination of the Savage well. The contaminant plume outside of OU1 is designated Operable Unit No. 2 (OU2), also called the extended plume area.

The State of New Hampshire Department of Environmental Services (NHDES) and the U.S. Environmental Protection Agency (USEPA) Region 1 have constructed a remedial system for the OU1 area (fig. 3). The remedial system consists of a barrier wall, which surrounds the highest concentrations of dissolved PCE and most likely some Dense Non-Aqueous Phase Liquid (DNAPLs), and includes various injection and extraction wells (vapor and water) to capture and treat the dissolved contaminant plume. The barrier wall was constructed from July to November 1998. Remedial operations of wells were tested from December 1998 to March 1999, but full operation started in May 1999.

The U.S. Geological Survey (USGS), in cooperation with the NHDES and the USEPA, Region 1, is studying the solute transport of VOCs (specifically PCE) in contaminated ground waters of the unconsolidated sediments of the Savage Municipal Well Superfund site. Specific objectives include:

1. Evaluate effectiveness of remedial operations at the $\mathrm{OK}$ Tool facility (OU1),

2. Help improve long-term (3-10 years) forecasting of PCE declines in the unconsolidated sediments on the basis of current remedial operations,

3. Identify important processes that affect contaminant transport, and

4. Improve upon long-term (more than 3 years) monitoring strategies by helping to design a cost-effective monitoring network.

The construction, calibration, and evaluation of solutetransport models discussed in this report will address these project objectives. The solute-transport models also will be used to assist in the design of additional remedial strategies in OU2 by simulation of hypothetical scenarios.

Previous studies by the USGS of the study site include construction and calibration of two ground-water-flow models (Harte and others, 1999; Harte and Mack, 1992), evaluation of effects of ground-water withdrawals on advective transport of contaminated ground waters (Harte and Willey, 1997), analysis of PCE trends for pre- and post-barrier conditions (Harte and others, 2001), and results of a monitoring program of continuous water levels (Brayton and Harte, 2001). The previous ground-water-flow modeling studies did not examine the effects of solute-transport properties on the dissolved PCE transport in ground water.

\section{Purpose and Scope}

This report describes the construction, calibration, and evaluation of solute-transport models of PCE for the Savage site. Two-dimensional and three-dimensional solute-transport models of the unconsolidated sediments were constructed and model results compared to field observations of PCE concentrations. Simulations performed and described in this report cover three time periods; an historical calibration from the initial PCE input stages (circa 1960) to the 1990s, a pre-remedial calibration from 1995 to 1998, and a remedial (post-barrier wall) calibration from 1998 to 1999. Because the primary VOC detected in the study area is PCE, which is one to three orders of magnitude greater than the secondary VOCs-(TCE, and cis-1,2DCE), only PCE is simulated.

\section{Description of Study Area}

The Savage site is underlain by an aquifer previously identified as the MSGD aquifer (Harte and Mack, 1992). The MSGD aquifer is defined as the entire sequence of unconsolidated sediments overlying the bedrock in the Souhegan River Valley of Milford, N.H.

The river valley slopes gently at $12 \mathrm{ft} / \mathrm{mi}$ along the river. Land-surface elevations range from 230 to $280 \mathrm{ft}$ above NGVD of 1929. The land drains to the Souhegan River and its tributaries (fig. 2), including Tucker, Purgatory, Great (not shown on map), and Hartshorn Brooks, and a number of small, unnamed streams. A discharge ditch drains processed waters from various manufacturing companies in the southwestern part of the study area.

Land use over the MSGD aquifer is predominantly industrial in the southwestern part, agricultural in the central and northwestern areas, and residential and commercial elsewhere. The contaminant plume (fig. 2) underlies a large agricultural area in the center of the plume (not shown on any figures) and abuts a commercial-industrial area to the south.

Current (2001) ground-water withdrawals are primarily used for commercial and industrial purposes. Withdrawal wells include two wells for the State Fish Hatchery in the northwestern part of the study area (well numbers 87 and 208, fig. 2) that 


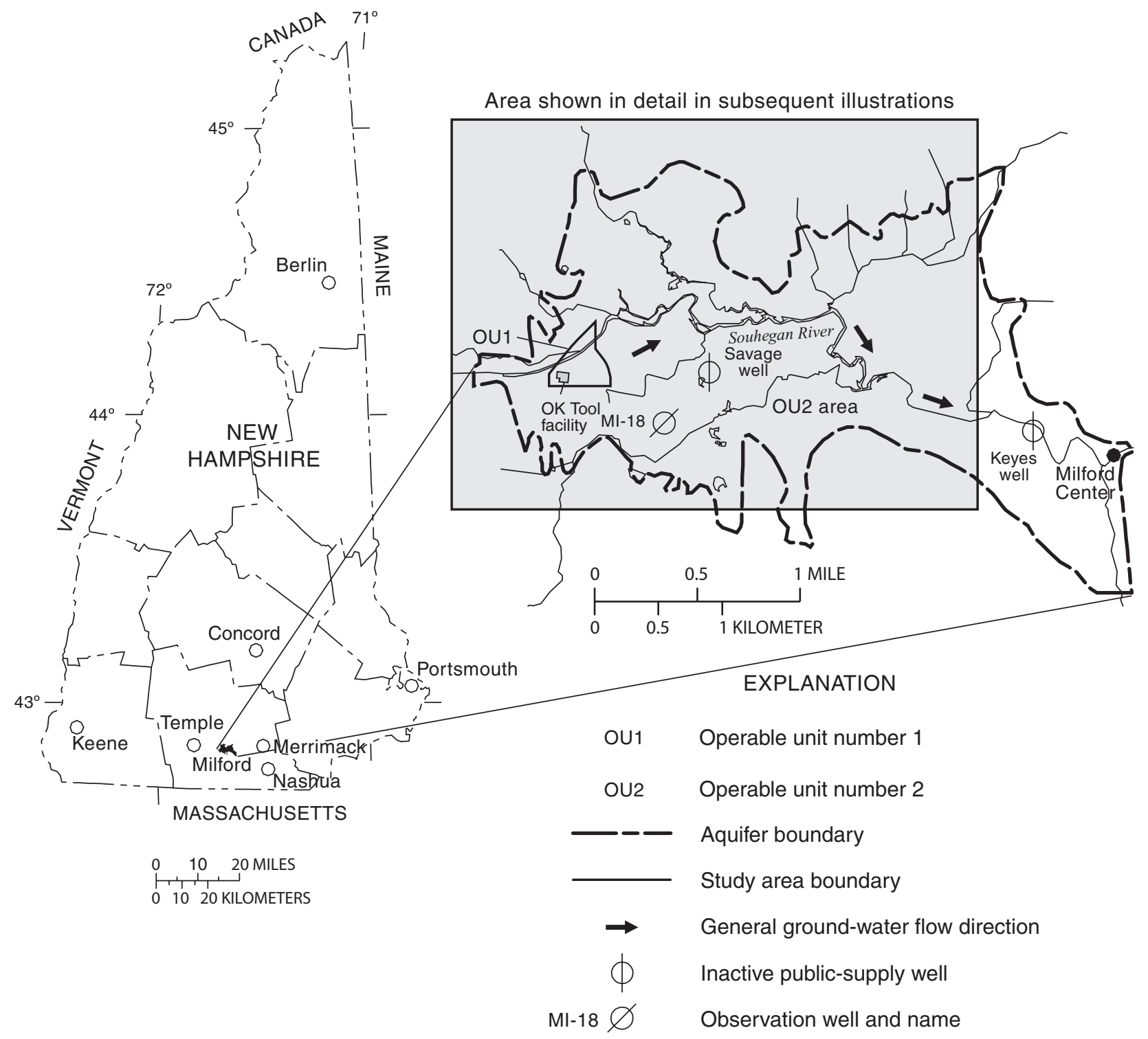

Figure 1. Location of the Milford-Souhegan glacial-drift aquifer, Savage well, and operable units 1 (OU1) and 2 (OU2) of the Savage Municipal Well Superfund site, Milford, N.H. 
A.

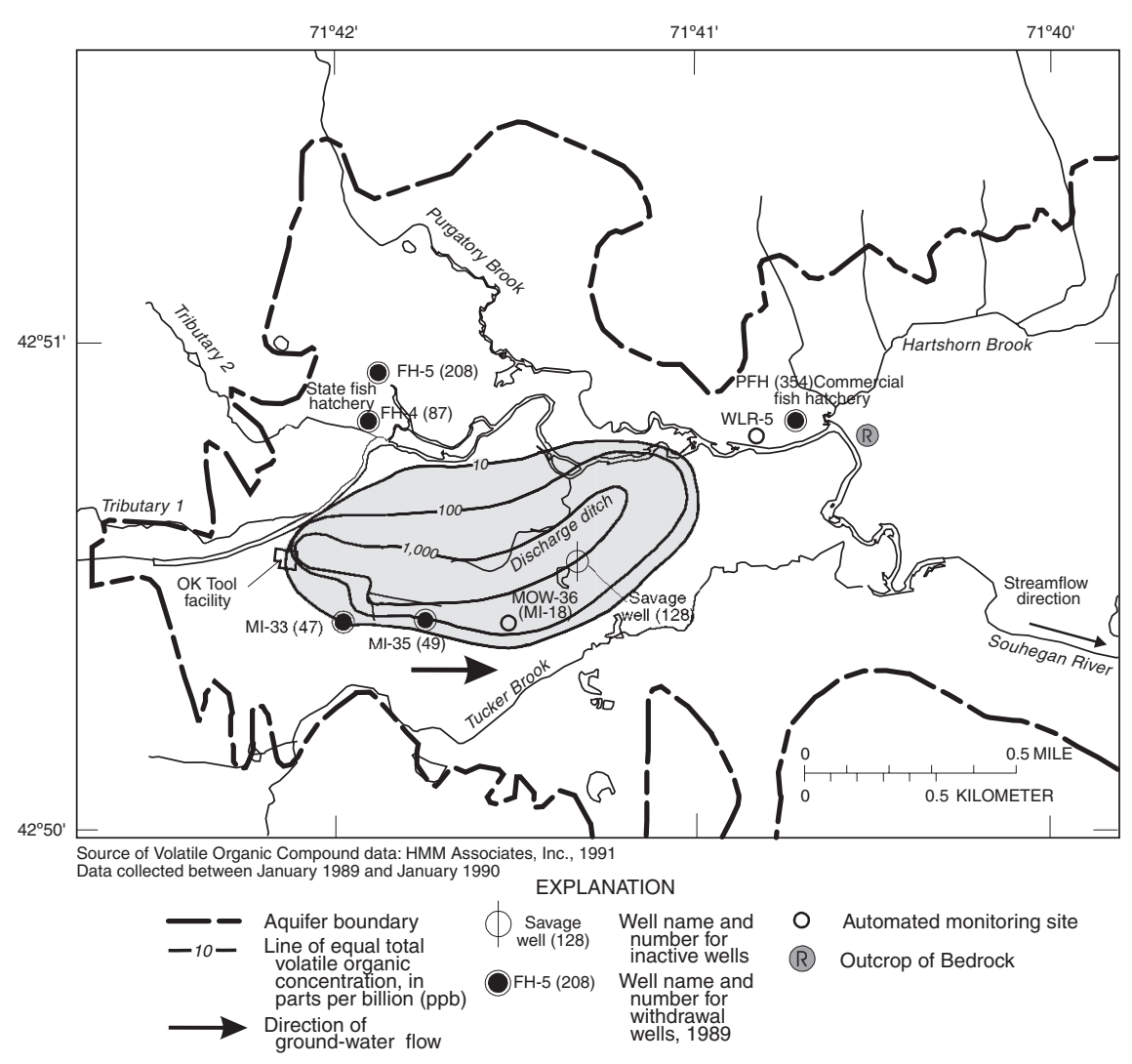

B.

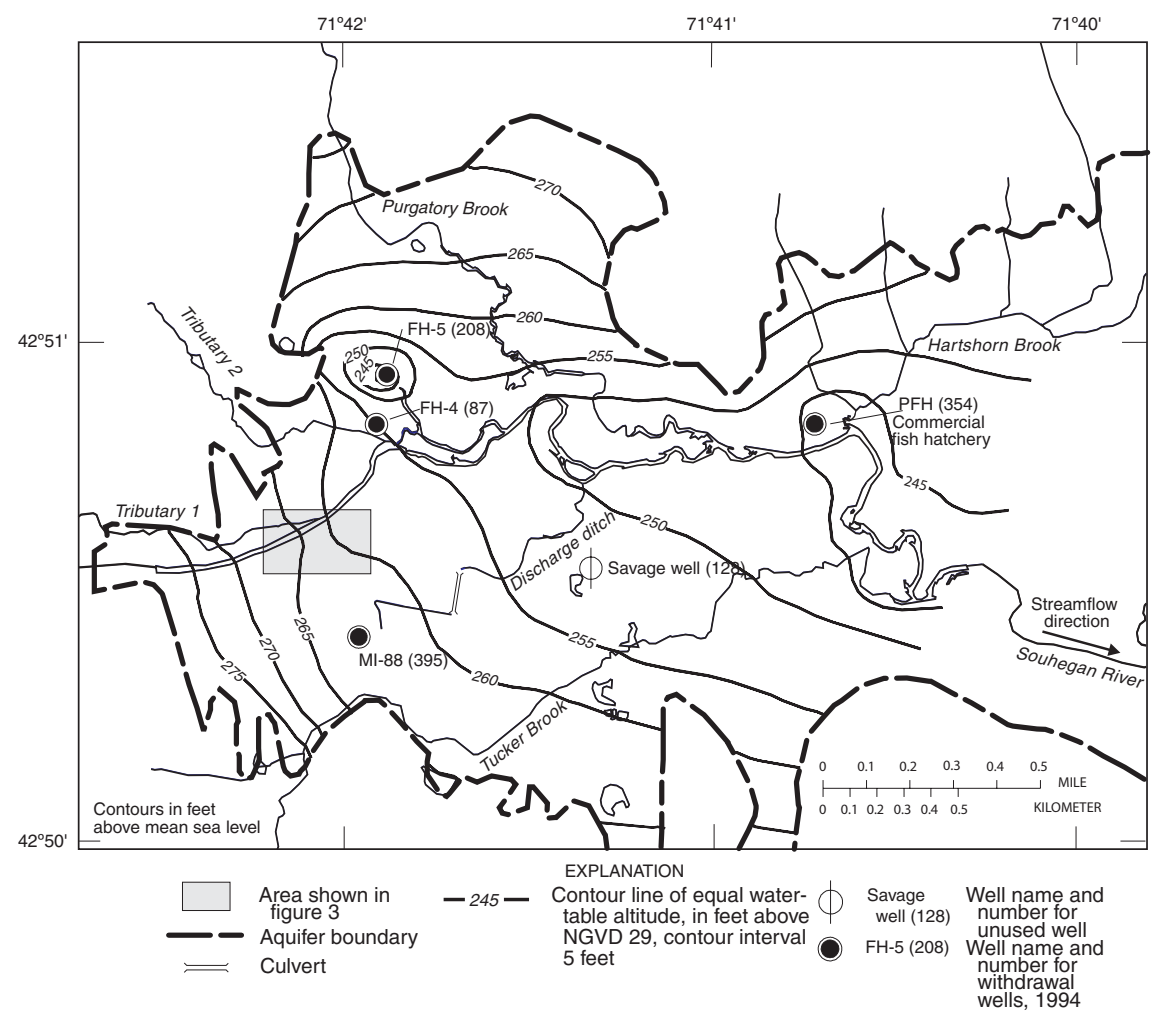

Figure 2. (A) Location of contaminant plume in 1989 of volatile organic compounds and (B) ground-water-head contours in 1994 in the Milford-Souhegan glacial-drift aquifer, Savage Municipal Well Superfund site, Milford, N.H. 


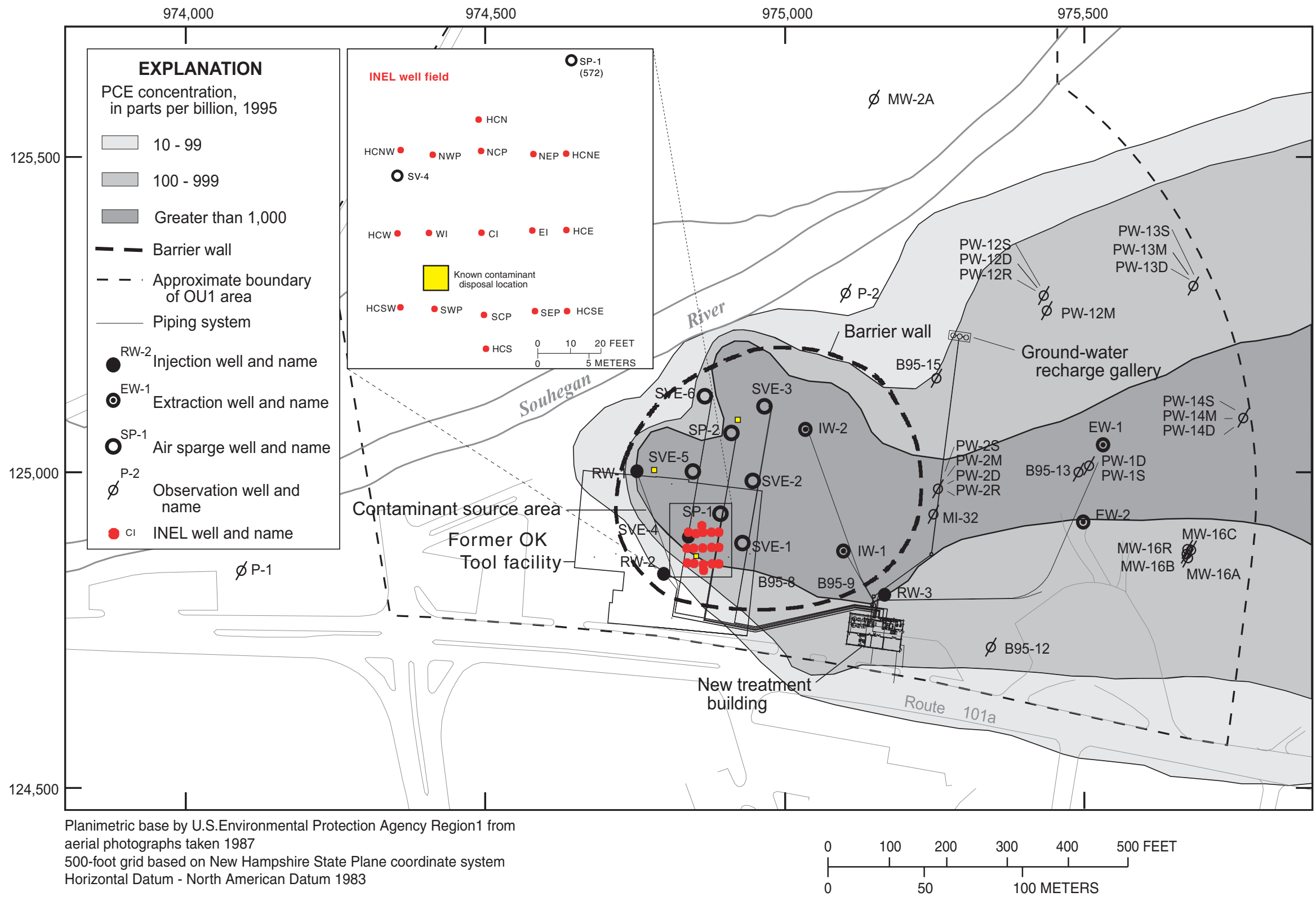

Figure 3. Remedial system, tetrachloroethylene (PCE) concentrations, and monitoring wells in the OK Tool facility (OU1) of the Savage Municipal Well Superfund site, Milford, N.H. 


\section{Solute Transport of Tetrachloroethylene in Ground Water of the Glacial-Drift Aquifer at the Savage Well Site, Milford, N.H.}

withdraw more than $2 \mathrm{Mgal} / \mathrm{d}$, a discontinued well at a private fish hatchery in the eastern part of the study area (well number 354 , fig. 2), and a well for an industrial and manufacturing complex in the southwestern part of the study area (well number 395, fig. 2) that withdraws about $0.25 \mathrm{Mgal} / \mathrm{d}$.

The OK Tool facility (OU1) has been identified as the primary source area of VOCs (HMM Associates, Inc., 1989, 1991) to the Savage well and is in the western part of the site. Solvents were discharged into the subsurface at this facility for many years until the early 1980s. Although discharges have ceased, the underlying contaminant-soaked sediments and immiscible solvents continued to contaminate ground water flowing easterly underneath the site and created a large plume $\left(0.5 \mathrm{mi}^{2}\right)$ until a barrier wall was constructed in 1998 .

The barrier wall is constructed of low-permeability materials (bentonite clay) and is designed to contain the highest concentrations of contaminants. The barrier wall encircles a $0.008-\mathrm{mi}^{2}$ area and the wall penetrates the full thickness of the sand and gravel unit and, in some cases the glacial till, and primarily sits atop the bedrock. Various injection and extraction wells (fig. 3, appendix 1, plates 1 and 2) were constructed to insure hydraulic isolation and reduce contaminant mass inside the barrier wall and to capture and treat the contaminants outside the barrier wall. Maximum concentrations of PCE, the primary contaminant, range from $100,000 \mathrm{ppb}$ inside the wall to $10,000 \mathrm{ppb}$ outside the wall (Camp, Dresser, and McKee, Federal Programs, 1995). Secondary VOCs (TCE and cis-1,2-

DCE) concentrations are typically one to two orders of magnitude less than those of PCE.

The remedial extraction wells in OU1 help capture PCEcontaminated ground water, where it is sent to a plant for decontamination and injection back into the aquifer. Extraction wells include soil vapor extraction (SVE) wells and water wells. SVE wells are inside the barrier and have been sporadically used from 1998 to 2000. Ground-water extraction wells include the IW-1 and IW-2 (fig. 3) inside the barrier. These wells capture PCD and also maintain inward hydraulic gradients, which reduce outflow of PCE from the barrier area. Two ground-water extraction wells (EW-1 and EW-2, fig. 3), outside and downgradient of the barrier, are used to capture PCE outside the barrier. Injection wells include two wells inside on the upgradient side of the barrier (RW-1 and RW-2, fig. 3). These wells are used to prevent inflow of clean, uncontaminated waters from outside the barrier and induce hydraulic gradients within the barrier. Another injection well (RW-3, fig. 3) is outside on the downgradient side of the barrier. A recharge gallery, outside the barrier on the northern flank of the plume (fig. 3), receives the bulk of the treated water and injects water into the shallow (less than $20 \mathrm{ft}$ ) subsurface. Air sparging (SP) wells (SP-1 and SP-2, fig. 3) are inside the barrier and are used to inject air into the deep overburden to facilitate transfer of VOCs, adhered onto soils, into the vapor phase. SP wells were primarily inactive from 1998 to 2000 .

\section{Hydrogeologic Setting}

The MSGD aquifer (fig. 1) is defined as the entire sequence of unsaturated and saturated alluvium, glacial drift, and other unconsolidated deposits overlying the bedrock surface in the Souhegan River Valley in Milford. The aquifer consists primarily of stratified sand and gravel with some basal till, and is overlain in places by recent alluvium. The maximum saturated thickness of the aquifer exceeds $80 \mathrm{ft}$, but generally ranges from 0 to $60 \mathrm{ft}$. The aquifer is bounded laterally by tillcovered bedrock uplands.

Two bedrock types have been identified in rock cores underlying the MSGD aquifer and include a white to pink, medium to coarse-grained granite and a gray, biotite-rich diorite gneiss (HMM Associates, Inc., 1989, 1991). Lyons and others (1997) identified various bedrock formations in the Milford area including the Massabesic Gneiss Complex of Late Proterozoic Age, an unnamed intrusive gray biotite granite of Permian Age, and an unnamed biotite quartz diorite of early Devonian Age (Spaulding Tonalite). A high-angle strike-slip fault called the Campbell Hill Fault traverses the area in a southwest-northeast trend.

Till forms the basal unit of unconsolidated sediments and discontinuously overlies bedrock (Harte and Mack, 1992). The till consists of a sandy to silty matrix. The till is thickest (greater than $20 \mathrm{ft}$ thick) in the westernmost part of the valley.

Stratified-drift deposits represent the most transmissive units underlying the site. Stratified drift was deposited as icecontact materials, glacial-lake deposits, fluvial deltas, and outwash materials (Koteff, 1970). During the late stages of glaciation, a west to east drainage pattern, similar to present drainage patterns, caused coarser sediments to be deposited in the western part of the valley. Specifically, glacial drainage occurred through the channel occupied by Purgatory Brook and through the channel occupied by the Souhegan River west of the contaminant source area. These glacial-drainage channels transported coarse-grained sediments into the present day Souhegan River Valley.

The unconsolidated sediments beneath the site consist of up to 100 -ft-thick deposits of predominantly sand and gravel. In OU1, lithologic logs show sand-and-gravel sequences are interspersed with discontinuous finer grained sands at depths of $40 \mathrm{ft}$ and $70 \mathrm{ft}$. Coarse-grained deposits (cobbles and gravels) occur at the uppermost layer near the water table (at a depth of $6-14 \mathrm{ft}$ ), at around $60 \mathrm{ft}$, and at the base of the unconsolidated sediments at $90 \mathrm{ft}$.

The stratigraphy was apparently created by a sequence of multiple glacial advances. The deep, coarse-grained deposits at 85-90 ft below land surface indicate that subglacial meltwater may have contributed to deep erosion into the bedrock. The remaining deposits indicate meltwater deposition in the form of deltas, outwash, and a glacial outburst deposit indicated by the coarse cobble zone near the uppermost sequence. The extent of the glacial outburst deposit appears to be limited to the western part of the aquifer. Farther east, in the upper strata, the predominant depositional unit is outwash. 
A partially penetrating river, the Souhegan River, bounds the northwestern part of OU1, and is the major source of recharge in this area. Farther downstream, the Souhegan River is a discharge sink for ground water. In areas near the Souhegan River, the ground-water-flow system responds quickly to variations in river stage, recharge from the river, or infiltration from precipitation; therefore, the flow system is highly transient.

Ground water flows to the east at velocities exceeding $3 \mathrm{ft} / \mathrm{day}$ in the aquifer. Ground-water-flow directions vary because of transient hydrologic conditions, which are induced by oscillations in river stage and variations in rates of recharge and discharge. Ground-water-flow velocities are highest (greater than $1.5 \mathrm{ft} / \mathrm{d}$ ) in the cobble zone deposit in OU1 and lowest (less than $0.5 \mathrm{ft} / \mathrm{d}$ ) in the basal till unit throughout the study area.

The interaction of ground water between the unconsolidated sediments and underlying bedrock is uncertain. In 1999, the USGS, in cooperation with the NHDES, and USEPA Region 1, began collecting continuous ground-water levels in the bedrock to help improve the characterization of the interaction between ground-water flow in the overlying unconsolidated sediments (overburden) and bedrock. The transmissive capabilities of the overburden are assumed to exceed that of the bedrock.

\section{Description and Trends of the Savage Site Volatile Organic Compound Plume}

The geographic extent, constituents, and spatial and temporal trends of the Savage site VOC plume is discussed in this section. A description of the physical and chemical characteristics of the VOC plume will help provide a rationale for methods applied to the simulation of the plume.

The first comprehensive analysis of the VOC plume was done in 1989 (HMM Associates, Inc., 1991) with the sampling of over 50 wells in the overburden and underlying bedrock. The primary VOC detected was PCE with a maximum reported value of 1,900 ppb. Secondary VOCs included TCE, TCA, and 1,2-DCE (1,2-dichloroethene). Maximum concentrations for the secondary VOCs were one-order less than that for PCE. The distribution of maximum concentrations of PCE from wells in the overburden in 1989 is shown in figure 2. Concentrations of VOCs were generally less in the bedrock (not shown) in 1989 than in the overburden.

Surface-water sampling of VOCs was limited to a discharge ditch that received non-contact industrial water from manufacturing facilities (see discharge ditch in figure 2) in the central part of the plume. Detectable VOCs included acetone, in addition to the aforementioned primary and secondary VOCs. The maximum concentration of any VOC detected was $400 \mathrm{ppb}$ for acetone.

From 1989 to 1994, the VOC plume shifted north as a result of decreases in ground-water withdrawals along the southern flank of the plume and increases in withdrawals along the northern flank of the plume (Harte and Willey, 1997). The distribution of the maximum concentration of PCE found at depth in 1989 and 1994 is shown in figure 4. The 10, 100, and $1,000 \mathrm{ppb}$ contours are farther north in 1994 than in 1989 indicating a shift of the VOC plume to the north.

In 1995, vertical profiling was used to provide an improved three-dimensional view of the VOC plume (plate 3). Vertical profiling was conducted using a direct-push method that provides discrete water-quality samples at predefined intervals. VOC samples were collected at vertical intervals of $5-10 \mathrm{ft}$ at 73 locations. The vertical profiling was done in transects, typically perpendicular to the principal northeasterly flow direction of the plume.

The maximum concentration of PCE from the vertical profiling exceeded 100,000 ppb in OU1. In OU2, the maximum concentration of PCE was 4,250 ppb (Environmental Science and Engineering, Inc., 1995, 1997). The maximum concentration of TCE exceeded 1,700 ppb in OU1 and $300 \mathrm{ppb}$ in OU2. (In 1995, cis-1,2-DCE was analyzed instead of 1,2-DCE as in 1989.) The maximum concentration of cis-1,2-DCE was $1,400 \mathrm{ppb}$ in OU1 and $400 \mathrm{ppb}$ in OU2. The maximum concentration of TCA was $80 \mathrm{ppb}$ in OU1 but exceeded $1,100 \mathrm{ppb}$ in OU2. The pattern of distribution of TCA in 1995 matched the distribution of TCA in 1989 and shows that the likely source of the high TCA concentrations is not from OU1, but from an area near the industrial supply well (fig. 2, by well MI-88).

A plot of contours of maximum concentration of PCE found at depth from the 1995 vertical-profiling survey shows a low concentration zone (less than 1,000 ppb) within a high concentration zone (greater than $1,000 \mathrm{ppb}$ ) in the middle area of the aquifer (fig. 5). This feature was not identifiable with the limited number of samples from wells used to construct the contours in the 1989 and 1994 maps (fig. 4). Also shown in figure 5 are graphs of PCE concentrations for selected wells. These graphs show large declines (up to 3,000 ppb) in PCE at well MW-17C along the southern edge of the plume, but small declines at wells along the centerline of the plume. In general, trends in concentrations of secondary VOCs follow trends in PCE concentrations. As reported in Harte and Willey (1997), large transverse shifts in the VOC plume have occurred over the years because of changes in patterns of ground-water withdrawals.

A partial three-dimensional (3-d) view of the distribution of PCE was constructed by slicing the overburden into discrete layers. This slicing was done to correspond with layering of a numerical solute-transport (MOC3D) subgrid constructed for this study. Slices were done in five layers with ranges of depths below the water table of $0-15 \mathrm{ft}$ for layer 1, 15-35 ft for layer $2,35-55 \mathrm{ft}$ for layer 3 , and greater than $55 \mathrm{ft}$ for layers 4 and 5 . Layers 4 and 5 were combined because of lack of data points to justify simulation with separate layers.

A cross section of model layers with some major hydrogeologic features is shown in figure 6. Model layers are subdued reflections of a hypothetical pre-stressed (predeveloped) water-table surface. The bottommost layer is the bedrock surface. 
A.

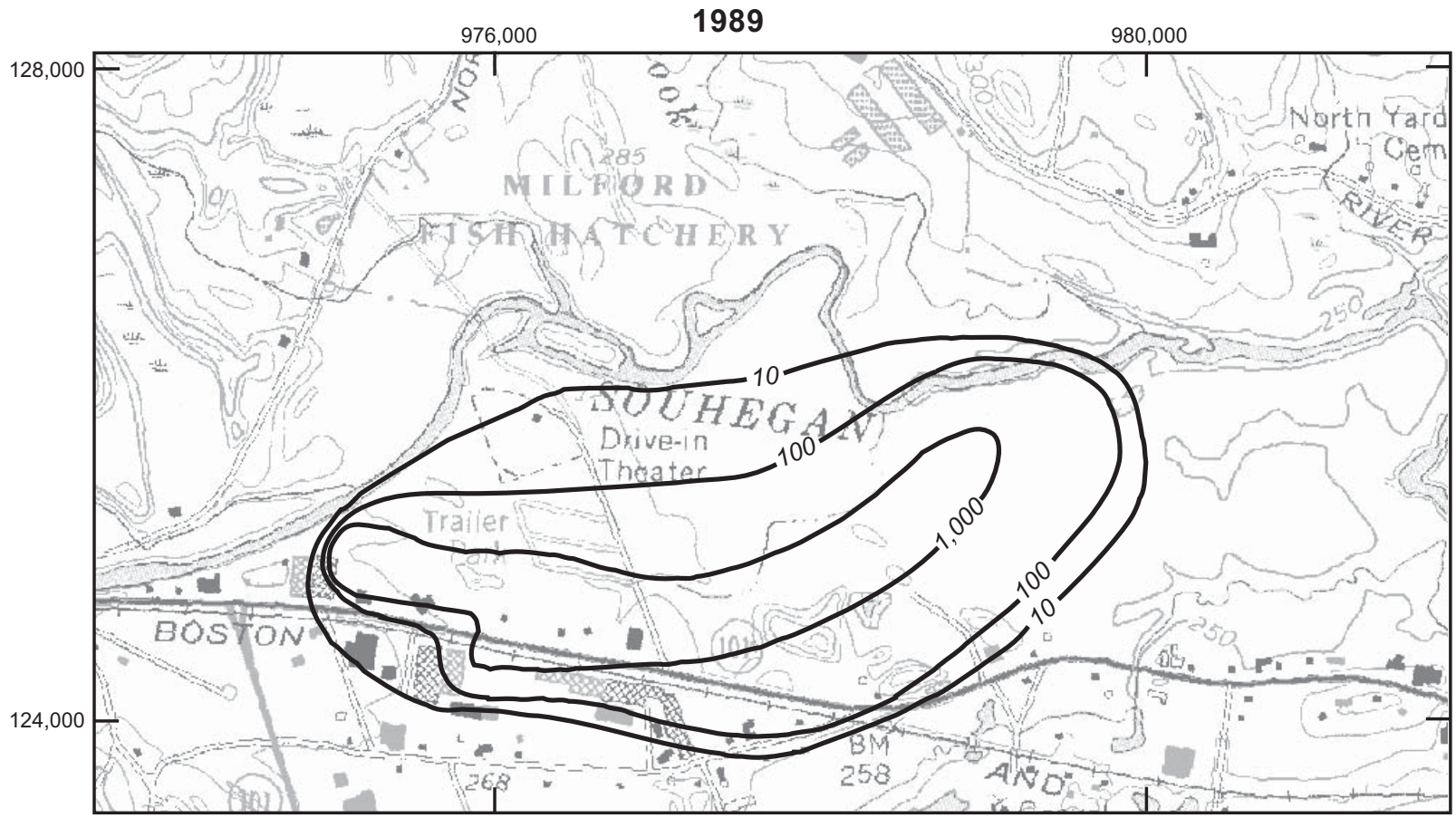

B.

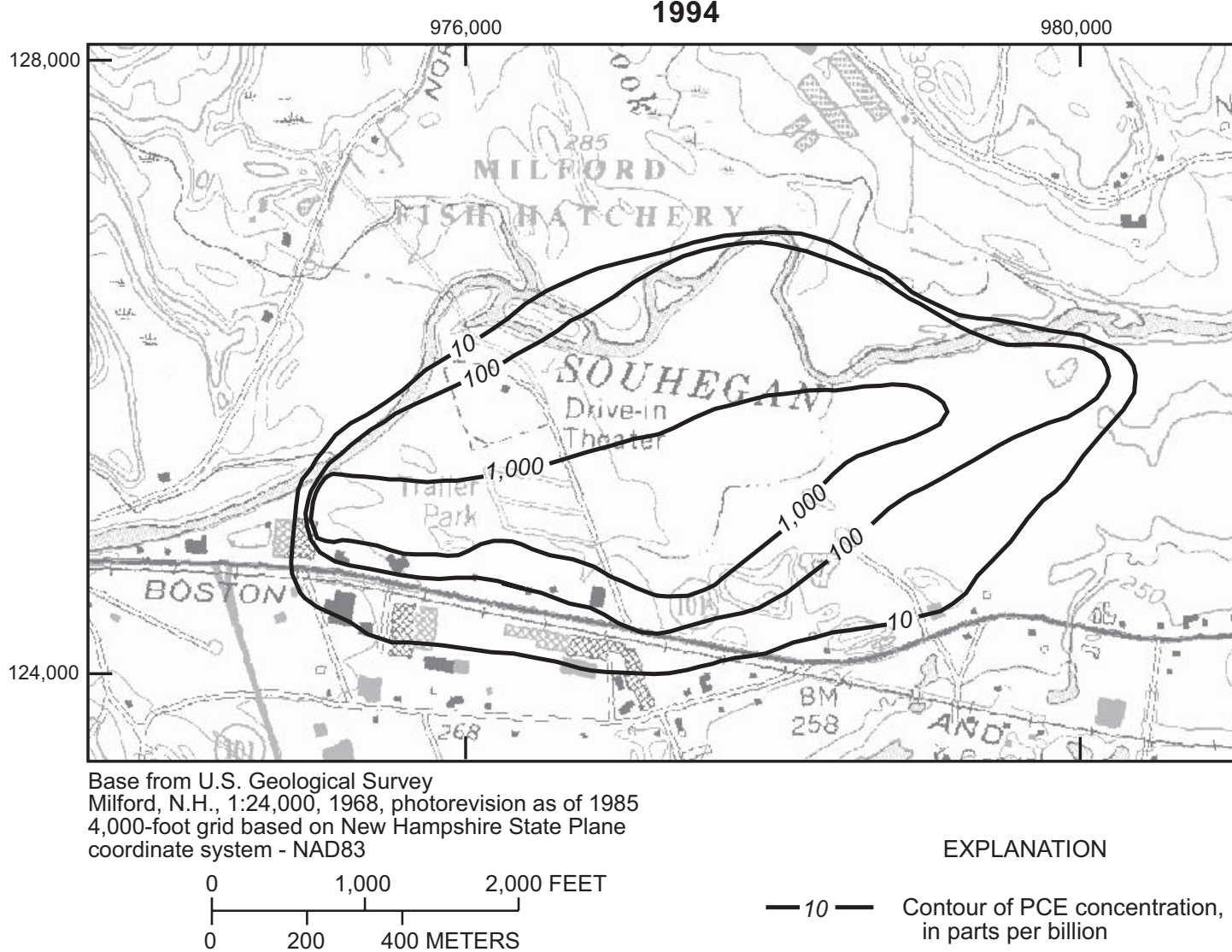

Figure 4. Contours of maximum tetrachloroethylene (PCE) concentrations in (A) 1989, and (B) 1994, in the Savage Municipal Well Superfund site, Milford, N.H. 


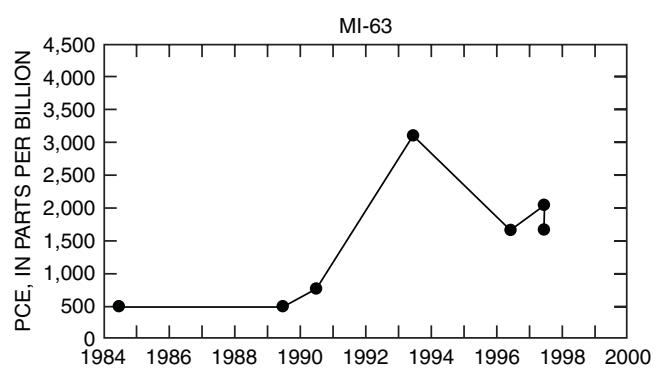

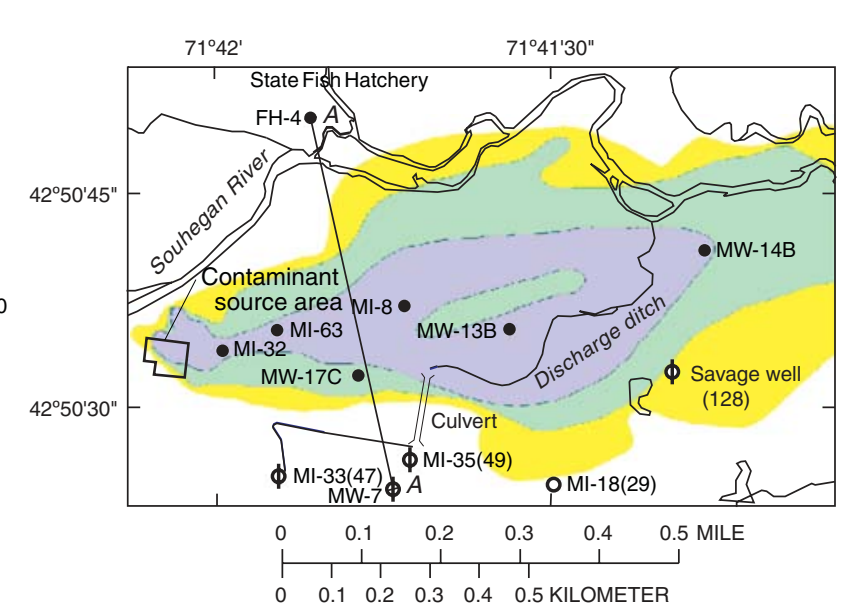

EXPLANATION

PCE concentration, in parts per billion

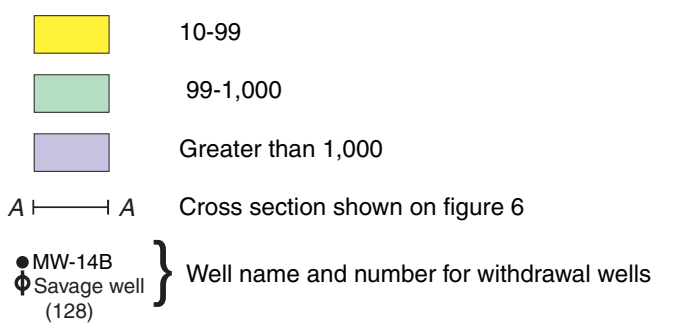

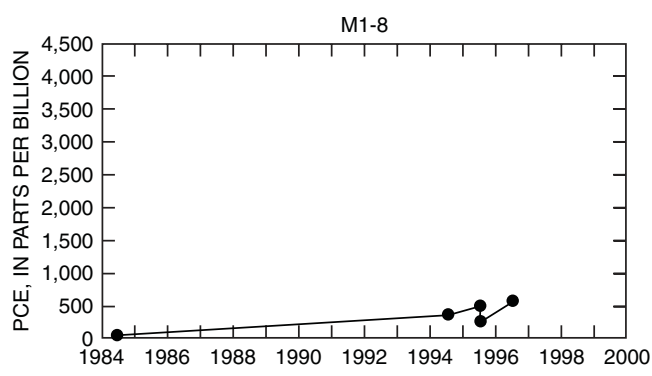

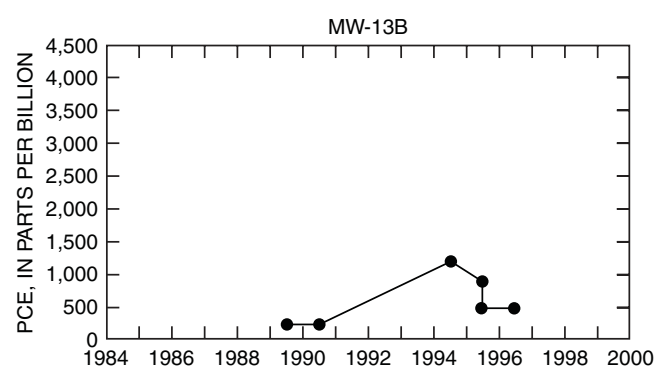

MW-14B

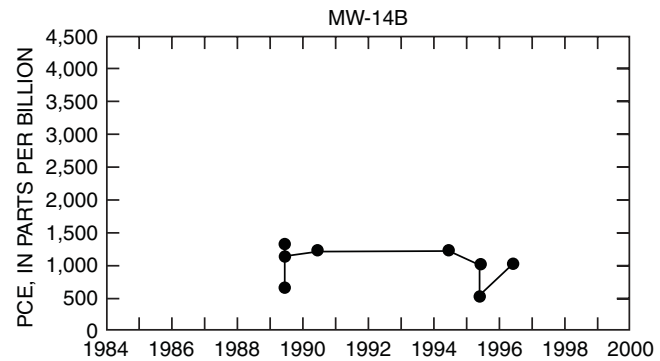

Figure 5. Contours of maximum tetrachloroethylene (PCE) concentrations in 1995 and graphs of PCE concentrations for selected wells, Savage Well Municipal Superfund site, Milford, N.H. 


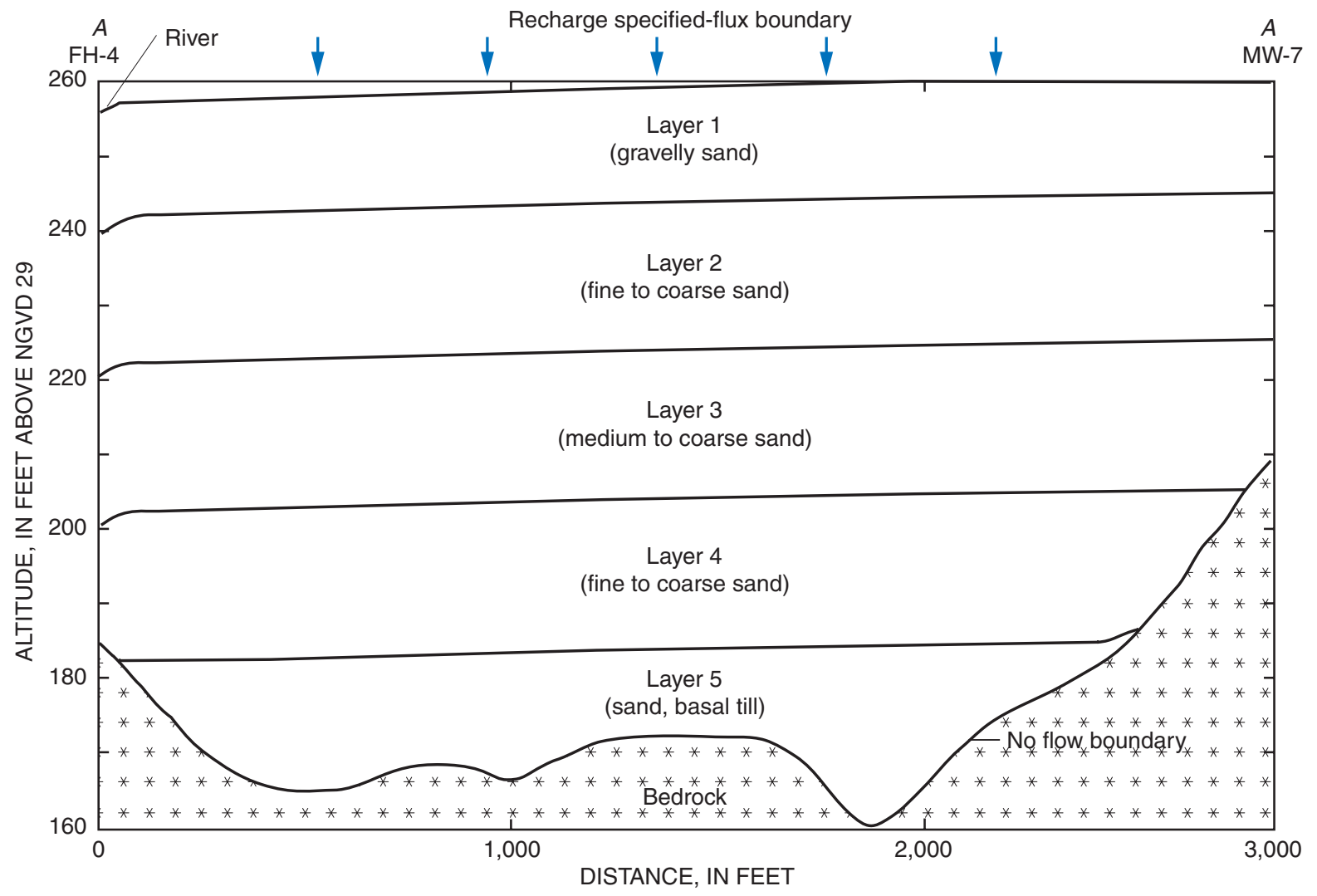

Figure 6. Generalized cross section of model layers, major hydrologic boundaries, and lithology. (Line of section shown on figure 5.)

An average PCE concentration was calculated per layer at vertical-profile points that had more than one sample point within a layer. Therefore, at each vertical-profile point, just one value was input into each layer even if several vertical samples may have been collected. In addition to vertical-profiling points, concentration data from up to 10 wells per layer were added to increase data resolution.

The interpolated PCE concentrations closely matched (less than 5 percent difference) the original inputted data concentration. Exceptions include the OU1 area (in an area contained within the barrier) and in areas with concentration less than $10 \mathrm{ppb}$. The discrepancy in the OU1 area results from the inability of the interpolated surface to match extremely large concentration gradients (areas with concentration differences of oneorder of magnitude). Interpolation was done to create a semicontinuous surface of PCE concentration data.

The results of the PCE interpolation are shown in figures $7-8$ as color ranges in concentrations. The area with PCE concentrations greater than $1,000 \mathrm{ppb}$ is largest in layer 3 and smallest in layer 1 . The $1,000 \mathrm{ppb}$ area in layer 4 is discontinuous because the layer pinches out in the middle of the over- burden from a rise in the underlying bedrock surface. Otherwise, layer 4 shows the highest concentration of PCE as shown by the large area in the western part of the plume. Concentrations in layer 5 were set equal to concentrations in layer 4 because of a lack of data in layer 5 to generate a computergenerated surface interpolation.

Trends in PCE and TCE concentrations were analyzed by comparing concentrations from commonly sampled wells. Although the location of the longitudinal axis of the plume has shifted over the last 10 years, comparing changes in individual well concentrations to changes in the overall concentrations of the same sampled wells provides some insight into the overall attenuation of the plume.

Sample statistics are summarized in two tables for three time periods-1994 (table 1), December 1998 (tables 1 and 2), and May 1999 (table 2). Statistical data for 1994 and December 1998 are summarized in table 1, and include more wells than are in table 2. Statistical data for 1994, December 1998, and May 1999 are summarized in table 2. Furthermore, data are separated into the two operational units OU1 and OU2 in both tables. By separating the data into these spatial groups, trends in mass 
A. Layer 1, 1995

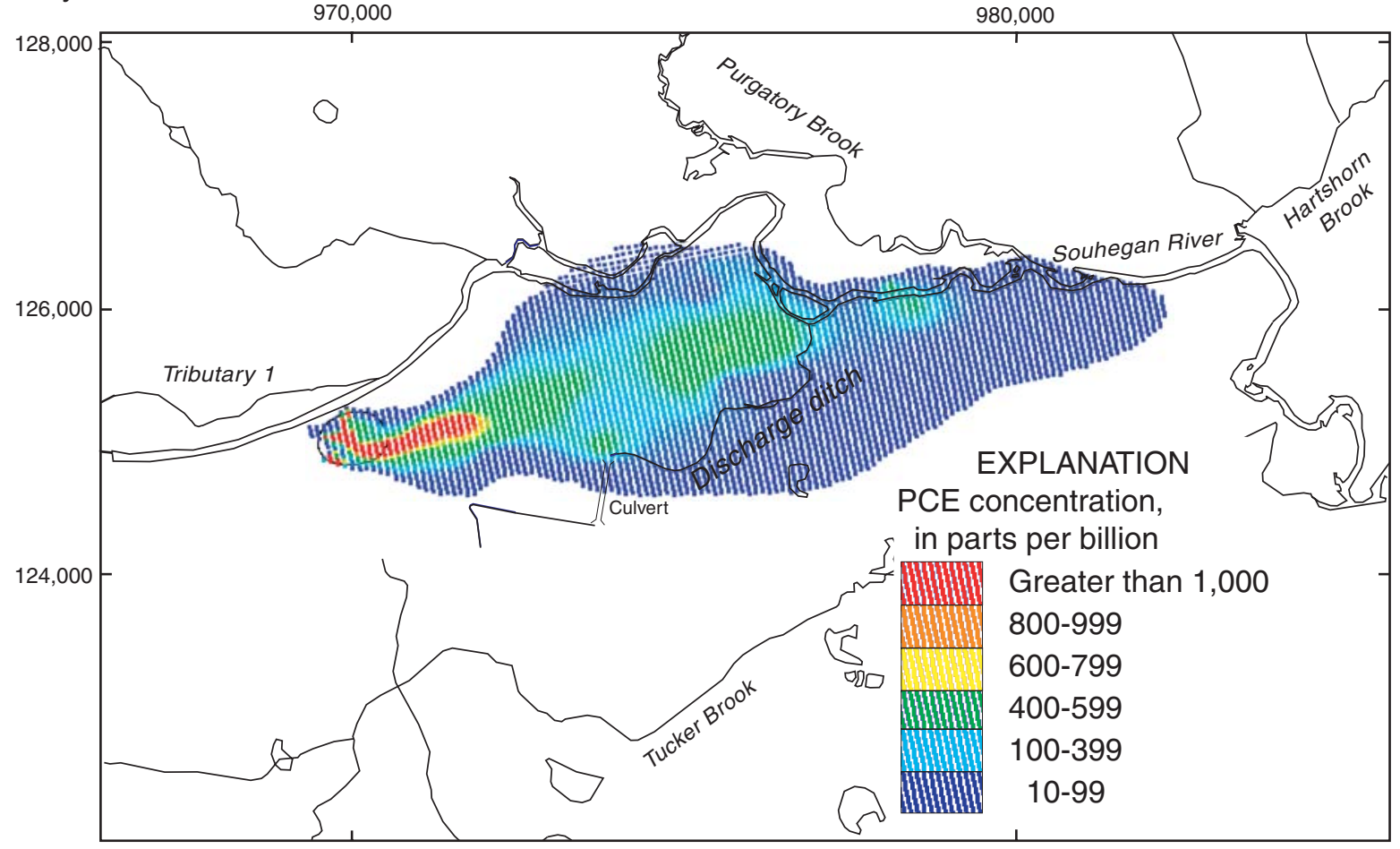

B. Layer 2, 1995

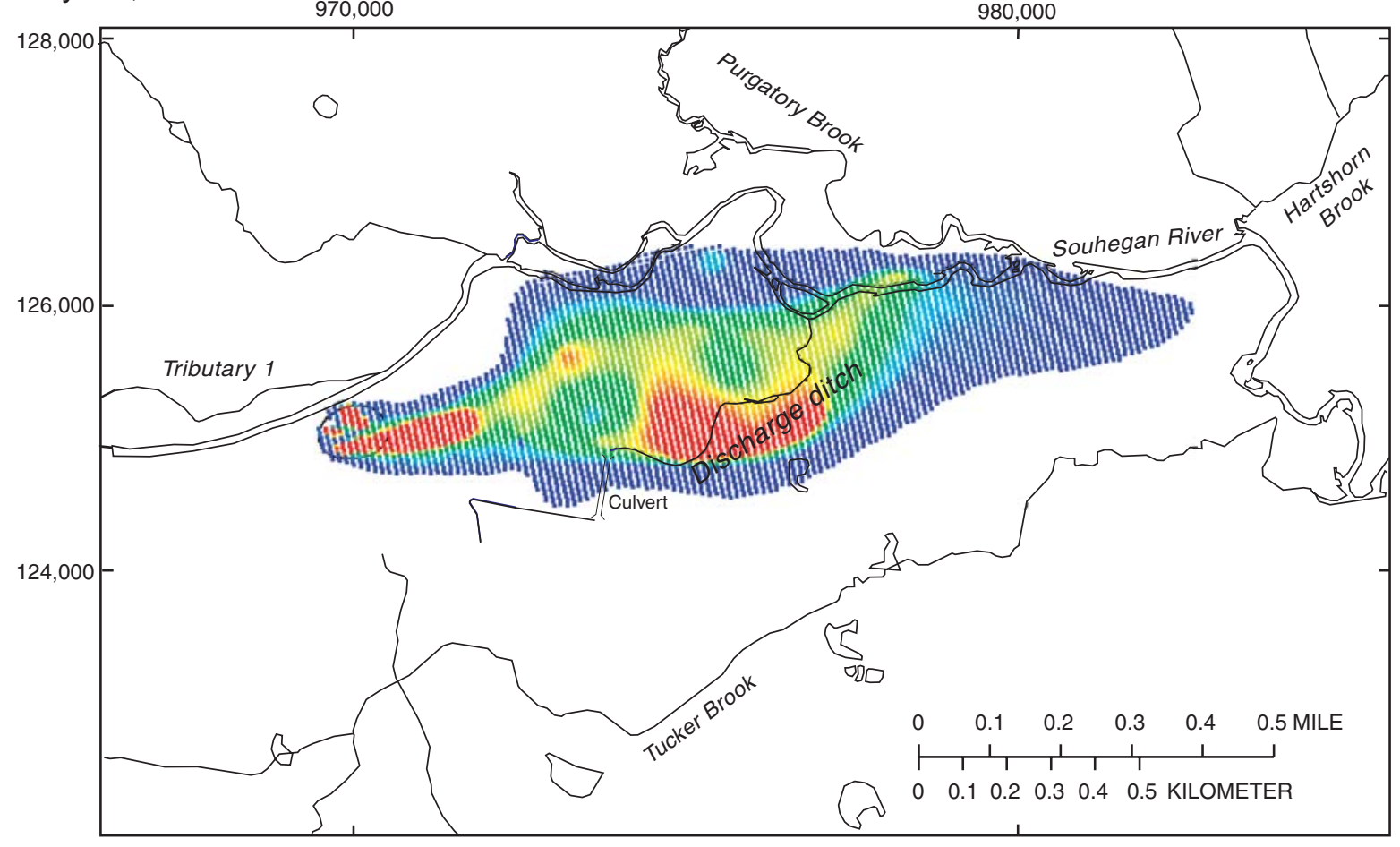

Figure 7. Contours of mean tetrachloroethylene (PCE) concentrations in model layers (A) 1 and (B) 2 as of 1995, Savage Municipal Well Superfund site, Milford, N.H. 
A. Layer 3, 1995

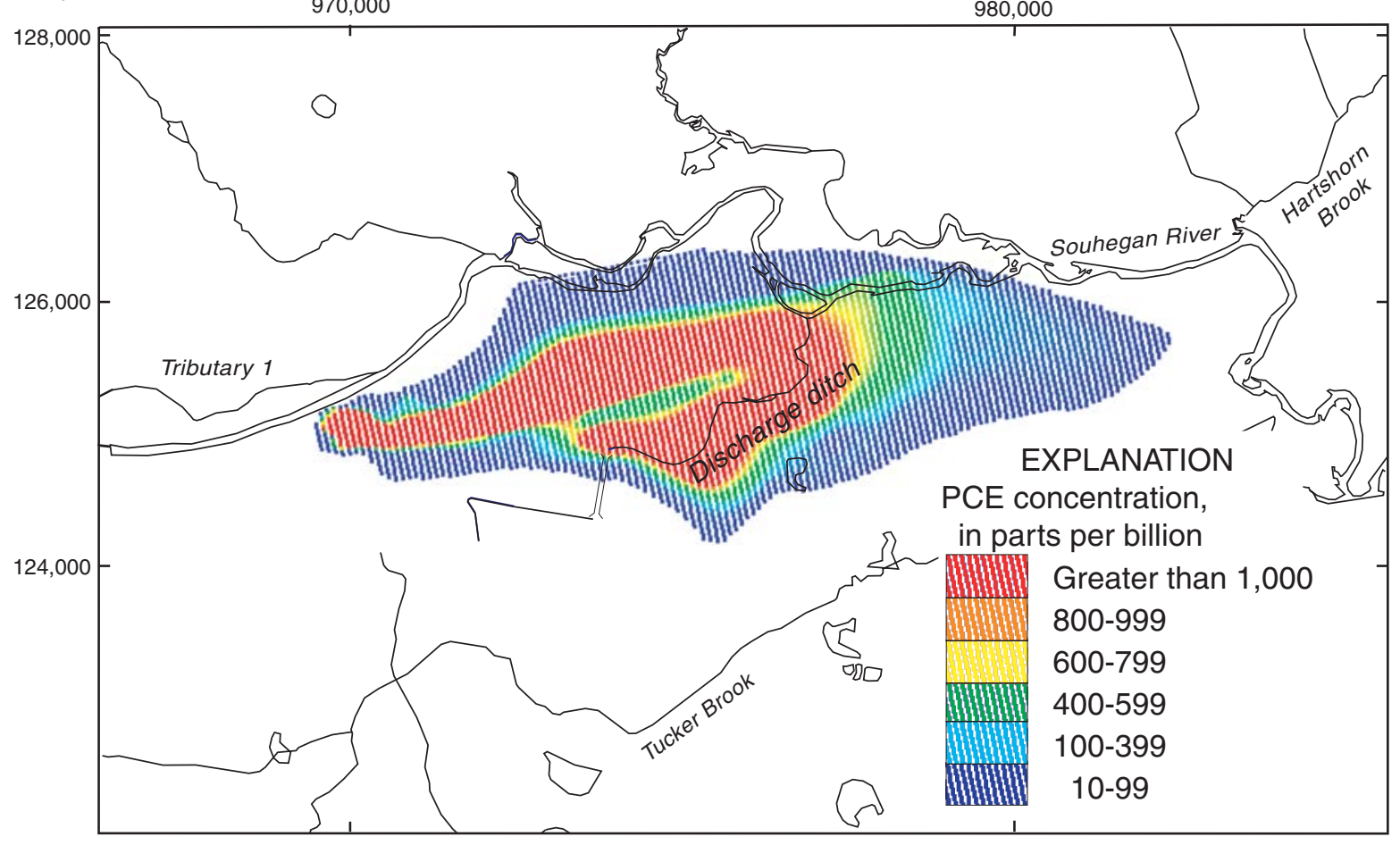

B. Layer 4, 1995

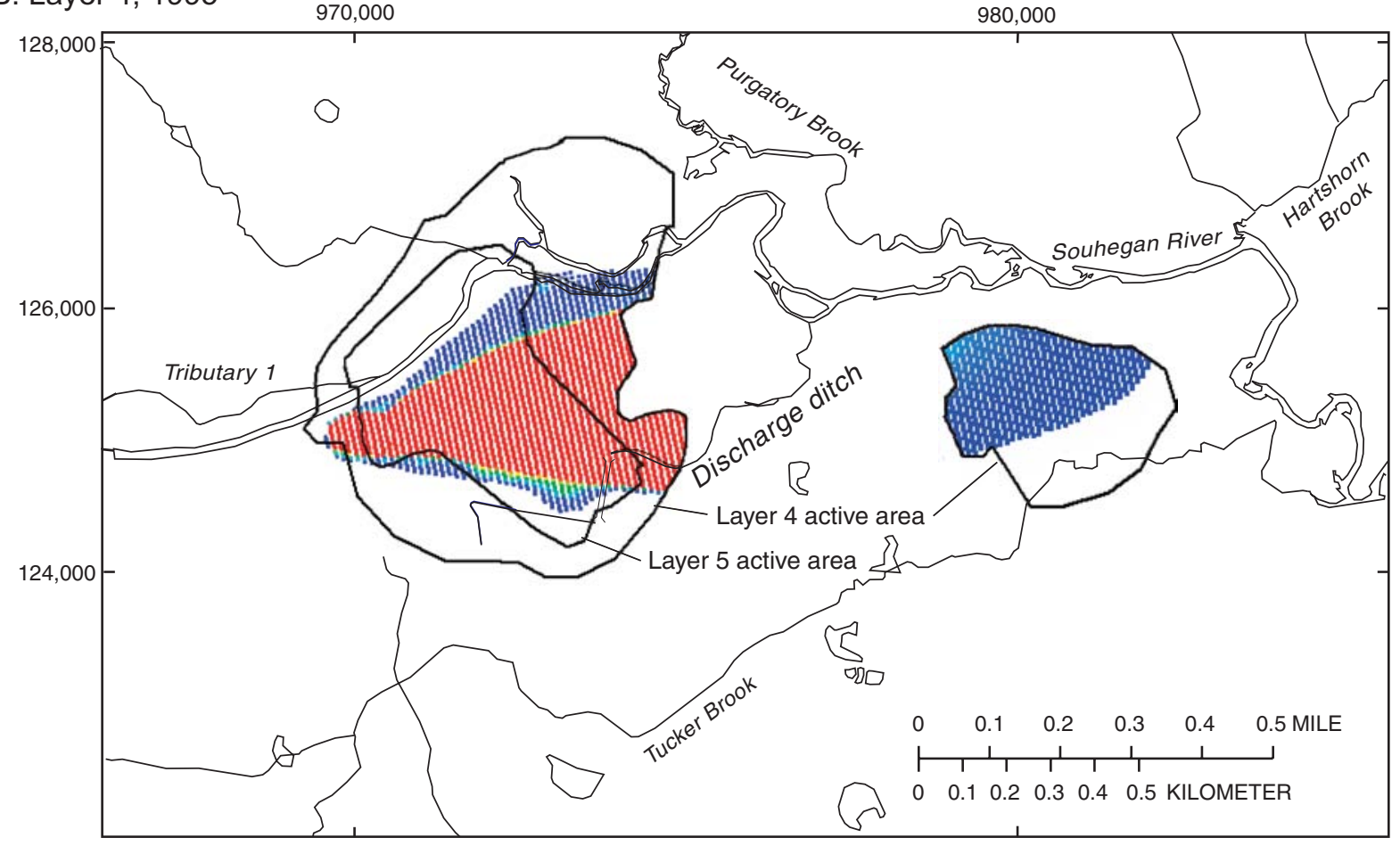

Figure 8. Contours of mean tetrachloroethylene (PCE) concentrations in model layers (A) 3 and (B) 4 as of 1995, Savage Municipal Well Superfund site, Milford, N.H. 
Table 1. Summary of PCE and TCE concentrations in samples collected between 1994 and December 1998 for commonly sampled wells at the Savage Municipal Well Superfund site, Milford, N.H.

[All concentrations in parts per billion; OU1, operable unit 1; OU2, operable unit 2; PCE, tetrachloroethylene; TCE, trichloroethylene]

\begin{tabular}{|c|c|c|c|c|}
\hline \multirow{2}{*}{ Statistics } & \multicolumn{2}{|c|}{$\begin{array}{c}\text { 0U1 wells } \\
\text { (Primary source area) }\end{array}$} & \multicolumn{2}{|c|}{$\begin{array}{c}\text { OU2 wells } \\
\text { (Extended plume area) }\end{array}$} \\
\hline & 11994 & ${ }^{2}$ December 1998 & 11994 & ${ }^{2}$ December 1998 \\
\hline \multicolumn{5}{|c|}{ Volatile organic compound: PCE } \\
\hline Number of samples & 6 & 6 & 38 & 38 \\
\hline Mean concentration & 1,693 & 778 & 379 & 161 \\
\hline Median concentration & 1,715 & 600 & 78 & 47 \\
\hline Standard deviation concentration & 1,158 & 641 & 604 & 227 \\
\hline \multicolumn{5}{|c|}{ Volatile organic compound: TCE } \\
\hline Number of samples & 6 & 6 & 32 & 32 \\
\hline Mean concentration & 90 & 69 & 27 & 15 \\
\hline Median concentration & 62 & 79 & 10 & 10 \\
\hline Standard deviation concentration & 85 & 57 & 35 & 16 \\
\hline
\end{tabular}

${ }^{1}$ QST Environmental, Inc., 1997.

${ }^{2}$ Harte and others, 2001; Allise M. deSmet, QST Environmental, Inc., written commun., March 1999.

Table 2. Summary of PCE and TCE concentrations in samples collected in 1994, December 1998, and May 1999 for commonly sampled wells at the Savage Municipal Well Superfund site, Milford, N.H.

[All concentrations in parts per billion; OU1, operable unit 1; OU2, operable unit 2; PCE, tetrachloroethylene; TCE, trichloroethylene]

\begin{tabular}{|c|c|c|c|c|c|c|}
\hline \multirow{2}{*}{ Statistics } & \multicolumn{3}{|c|}{$\begin{array}{c}\text { OU1 wells } \\
\text { (Primary source area) }\end{array}$} & \multicolumn{3}{|c|}{$\begin{array}{c}\text { 0U2 wells } \\
\text { (Extended plume area) }\end{array}$} \\
\hline & 11994 & 2December 1998 & ${ }^{3}$ May 1999 & 11994 & 2December 1998 & ${ }^{3}$ May 1999 \\
\hline \multicolumn{7}{|c|}{ Volatile organic compound: PCE } \\
\hline Number of samples & 4 & 4 & 4 & 20 & 20 & 20 \\
\hline Mean concentration & 1,715 & 618 & 578 & 579 & 265 & 264 \\
\hline Median concentration & 1,910 & 505 & 475 & 135 & 110 & 140 \\
\hline Standard deviation concentration & 1,344 & 584 & 523 & 717 & 264 & 279 \\
\hline \multicolumn{7}{|c|}{ Volatile organic compound: TCE } \\
\hline Number of samples & 4 & 4 & 4 & 15 & 15 & 15 \\
\hline Mean concentration & 81 & 44 & 44 & 44 & 24 & 24 \\
\hline Median concentration & 60 & 25 & 30 & 31 & 20 & 29 \\
\hline Standard deviation concentration & 88 & 53 & 47 & 38 & 18 & 16 \\
\hline
\end{tabular}

${ }^{3}$ QST Environmental, Inc., 1997.

${ }^{4}$ Harte and others, 2001; Allise M. deSmet, QST Environmental, Inc., written commun., March 1999.

${ }^{5}$ Harte and others, 2001; Allise M. deSmet, QST Environmental, Inc., written commun., June 1999. 
input of PCE from the DNAPL source in OU1 can be assessed. For example, decreases of PCE concentration in OU2 may result from decreases in mass input from OU1, changes in attenuation in OU2, or both. If changes from mass input are the primary causes of decreases in PCE concentrations, relatively similar changes will occur between OU1 and OU2.

For wells common to the sampled periods in 1994 and December 1998, which includes 6 wells in OU1 and 38 wells in OU2 for PCE, and 6 wells in OU1 and 35 wells in OU2 for TCE, the mean PCE concentration decreased by approximately half in OU1 wells and a similar amount in OU2 wells (table 1) as measured by the decreases from 1994 to December 1998. The mean TCE concentration decreased by approximately one-third in OU1 wells and half in OU2 wells from 1994 to December 1998. The median PCE concentration decreased by two-thirds in OU1 wells and less than half in OU2 wells. The median TCE concentrations were fairly similar (62 (1994) and 79 (1998) ppb in OU1 and 10 (1994 and 1998) ppb in OU2) for the two periods for both OU1 and OU2. Values of standard deviation were largest for 1994 and smallest for December 1998 in OU1 and OU2 for PCE and TCE. Thus, on the basis of the changes in mean concentration in PCE, changes in mass input of PCE from sources in OU1 are the likely cause of decreases of PCE in OU2 because PCE decreases in OU1 and OU2 were similar.

For wells common to the sampled periods in 1994, December 1998, and May 1999, which includes 4 wells in OU1 and 20 wells in OU2 for PCE, and 4 wells in OU1 and 15 wells in OU2 for TCE, the mean PCE concentration decreased by approximately half from 1994 to December 1998 (table 2). This decrease was similar with wells common to the two sampled periods only (table 1). Mean TCE concentrations decreased by slightly less than half from 1994 to December 1998. In contrast, there are essentially no changes in mean concentrations of PCE or TCE from December 1998 to May 1999. Median concentrations of PCE and TCE for OU1 and OU2 follow a trend similar to mean PCE and TCE concentrations. Values of standard deviation for PCE and TCE concentrations are largest for 1994 and smallest for December 1998 and May 1999 in OU1 and OU2.

Time trends in the mean concentration of PCE from commonly sampled wells were further analyzed by fitting a firstorder exponential equation to concentrations. The first-order exponential equation is defined as

$$
C=C_{o} e^{-k t}
$$

where

$$
\begin{aligned}
C & =\text { concentration, in parts per billion; } \\
C_{o} & =\text { initial concentration, in parts per billion; }
\end{aligned}
$$

and

$t \quad=$ time in years.
Samples were collected during July 1989, December 1994 , July 1996, May 1997, December 1998, and May 1999. Sampled wells were grouped spatially into the OU1 and OU2 areas.

Commonly sampled wells were unavailable for all of the above dates for OU1 wells (dates missing include December 1998 and May 1999) and OU2 wells (dates missing include July 1989 and May 1997).

An exponential rate constant $(k)$ of 0.13 was calculated for OU1 and 0.17 for OU2. Although the rate constant is greater for the OU2 data than for the OU1 data, which indicates a slightly steeper decline in PCE concentrations in OU2 than in PCE concentrations in OU1, the two-slope constants are comparable.

In summary, the results of the analyses on time trends indicate that, overall, PCE and TCE concentrations declined steeply between 1989 and 1999 in OU1 and OU2. Most of the decrease in concentrations in the entire plume (OU1 and OU2) probably results from a corresponding decrease in mass input of PCE and TCE from the OU1 area.

\section{Description of Processes Affecting Solute Transport of Tetrachloroethylene}

An overview of solute-transport processes affecting PCE and selected associated VOC compounds is discussed in this section. Examples of solute transport from other field sites are included to provide comparisons with the Savage site.

PCE is a member of the chlorinated aliphatic group of VOCs. Chlorinated aliphatic compounds-PCE, TCE, and their degradation products like cis-1,2-DCE — are among the most widely observed contaminants found in shallow ground-water systems (Chapelle, 1993). Chlorinated aliphatic compounds are persistent in ground water because of their widespread use in industry as a solvent, the improper disposal of these compounds in the environment, their high solubility and mobility in water, and their relative recalcitrance to degradation. The solubility of a pure product of PCE in water is relatively high $(150 \mathrm{mg} / \mathrm{L})$ but lower than a pure product of TCE $(1,100 \mathrm{mg} / \mathrm{L})$.

Solute fate and transport processes of PCE are governed by advection, reversible reactions (retardation and sorption), and irreversible reactions (degradation and volatilization), dispersion, diffusion, and dilution. Advection is the movement of solute by bulk ground-water flow. Other chemical and physical processes affecting solute transport of PCE are discussed in this section.

The rate of solute transport of PCE is often less than the average rate of ground-water flow. These differences in rate can be described by the retardation factor (retardation) (Zheng and Bennett, 1995). The higher the retardation, the slower the transport of the PCE solute will be relative to the bulk or average movement of ground water. Retardation is caused by sorption of solute onto geologic materials. The retardation factor is based on the principle of a linear isotherm where an instantaneous linear equilibrium between the sorbed and dissolved concentration is assumed. In some cases, non-linear or alternate isotherms 
may more appropriately describe the relation of sorbed and dissolved concentration. An example of an alternate isotherm is the Langmuir isotherm, which assumes that sorption does not occur beyond a maximum sorption threshold. Lorah and others (1997) showed that linear isotherms adequately represented the sorbed and dissolved concentrations of PCA, TCE, and cis-1,2-DCE under anaerobic 24-hour batch experiments, which indicates a relatively rapid linear equilibrium relation exists between sorbed and dissolved concentrations for these compounds. For this study, PCE is expected to behave similarly.

The amount of PCE sorption will depend on the organic carbon content $(f o c)$ of the subsurface materials, porosity, bulk density, and the partition coefficient of PCE. Therefore, the amount of organic carbon is a key factor in quantifying sorption because the amount of noncarbon sorption is typically low in saturated materials (Chiou, Henry, U.S. Geological Survey, written commun., 2001). The foc and retardation of PCE and other similar compounds is given in table 3 from a number of field sites including the Savage site. The average foc from geologic materials underlying the Savage site is lower than the foc from other field sites indicating a tendency for relatively less retardation at the Savage site.

Degradation of PCE to daughter product (TCE) occurs from reductive dechlorination but also can occur as a result of cometabolism in aerobic environments (McCarty, 1994) and(or) abiotic degradation. For reductive dechlorination to occur, a suitable electron donor must be available. The principal electron donor is native organic carbon but other co-contaminants can serve as electron donors. Co-contaminants to chlorinated aliphatic compounds include petroleum hydrocarbons and methanol. The Savage site has low organic carbon and negligible co-contaminant compounds. In contrast, reductive dechlorination is a major degradation process of TCE attenuation at the USGS Toxic Waste Study Site at Picatinny Arsenal in New Jersey and St. Joseph site in Michigan (table 3). At the Picatinny Arsenal site, anaerobic degradation accounts for 70 percent of the total attenuation of TCE (Imbrigiotta and Ehlke, $1999)$ and the degradation-rate constant, primarily from anaerobic degradation, is high ( $k=-1.82$, table 3$)$. Evidence of degradation is less clear at the Savage site because of a lack of accumulated daughter products and limited geochemical evidence of reductive reactions. Geochemical evidence of degradation includes reduction of electron acceptors such as dissolved oxygen, nitrate, sulfate, and iron (II) within a plume. Ethane or ethene end products of a complete biodegradation process generally have not been detected at the Savage site; therefore, the site can be characterized as an incomplete or limited degraded plume.

PCE can also volatilize across the water-table surface but generally less than TCE and some other VOCs because PCE has a relatively low vapor pressure. Rates of volatilization have been documented for TCE at the Picatinny Arsenal. Volatilization accounted for 15 percent of the total attenuation of TCE at Picatinny Arsenal (Imbrigiotta and Ehlke, 1999).

Dispersion, diffusion, and dilution also are factors affecting PCE solute transport. Dispersion is a function of the mechanical tortuosity of geologic materials, variation in veloc- ity of ground water because of transient recharge and discharge conditions, and the average velocity of ground water (Goode and Konikow, 1990). Dispersion is highly correlated with plume size (Gelhar and others, 1985, 1992). Large plumes with high rates and variability of ground-water flow exhibit increased rates of dispersion. The Savage site is assumed to have a large rate of dispersion on the basis of the size of the plume and rapidity of flow. Diffusion is the spreading and dilution of contaminants as a result of molecular diffusion. Diffusion is dependent on contaminant properties and concentration gradients as described by Fick's Law. Few examples of field cases exist that clearly demonstrate diffusion processes where the plumes are dominated by advection as the principal mechanism of solute transport. Dilution is a function of contaminants mixing with uncontaminated waters and tends to be higher at sites with high ground-water recharge rates. Recharge at the Savage site is probably comparable to, if not greater than, recharge at the other sites listed in table 3.

The totality of solute-transport processes can be quantified by the apparent-loss coefficient. Apparent-loss coefficients from the decline of VOC concentrations in various plumes are listed in table 3. The apparent-loss coefficient, also called the attenuation-rate constant (Wilson and others, 1994), is described following a first-order rate equation (table 3 ). The apparent-loss coefficient defines the decline of VOC concentrations from upgradient to downgradient plume locations and can be used as a measure of transport and general reactivity of VOCs.

The apparent-loss coefficient for the Savage site was computed from changes in mass of PCE between two transect lines of vertical-profiling points that were aligned perpendicular to the longitudinal direction of transport according to methods described in Wilson and others (1994). The transect lines are assumed to intercept the entire width and depth of the plume. PCE mass was computed from transects installed in 1995 (Camp, Dresser, and McKee, Inc., 1995; and Environmental Science and Engineering, 1995). Transect lines VP-2000 (in OU1) and line D (in the middle of the plume in OU2) were chosen to compute PCE mass because of their areal and vertical coverage (plate 3). PCE mass declined by 25 percent between the transect lines. An apparent-loss coefficient of -0.06 per year (negative indicating a decline) was computed and is equivalent to a half-life of 10.5 years; this rate compares favorably to rates computed at the Picatinny Arsenal site but is lower than rates at the St. Joseph site (table 3).

A potentially unaccounted-for loss of PCE mass, between the two measured transect lines, at the Savage site is discharge of PCE to the bedrock, which would produce a bias (overestimate) in the apparent-loss coefficient because the method assumes that the entire plume is sampled. Anecdotal evidence suggests there is some PCE discharge to the bedrock. A bedrock well (MW-11 cluster, well number 219, plate 1) near line D (plate 3) showed an increase in PCE concentrations from sampled waters in the mid to late 1990s. Consequently, the computed apparent-loss coefficient for the Savage site is viewed as an upper limit value. 
Table 3. Summary of physical and chemical characteristics of select volatile organic compound plumes in North America.

$\left[\mathrm{mi}^{2}\right.$, square mile; $\mathrm{ft} / \mathrm{d}$, foot per day; $\mathrm{f}_{\mathrm{oc}}$, mass fraction of geologic material containing organic carbon; $\mathrm{R}_{\mathrm{f}}$, retardation coefficient; rate constant $(\mathrm{k})=1 /$ time $(\mathrm{yrs})$ $\ln \left(\mathrm{c} / \mathrm{c}_{\mathrm{o}}\right)$, where $\mathrm{c}=$ concentration and $\mathrm{c}_{\mathrm{o}}=$ initial concentration; PCE, tetrachloroethylene; PCA, 1,1,2,2-tetrachloroethane; TCE, trichloroethylene; --, no data; cis-1,2 DCE, cis-1,2 Dichloroethylene; Apparent loss coefficients same as attenuation rate constants; $\left.\Xi=\mathrm{v}_{\mathrm{x}} / 4_{\mathrm{x}}\left(\left[1+2_{\mathrm{x}}\left(\mathrm{k} / \mathrm{v}_{\mathrm{x}}\right)\right]^{2}-1\right)\right]$

\begin{tabular}{|c|c|c|c|c|c|c|c|c|c|}
\hline Site name & $\begin{array}{c}\text { Volatile } \\
\text { organic } \\
\text { com- } \\
\text { pound }\end{array}$ & Reference & $\begin{array}{l}\text { Geologic } \\
\text { materials }\end{array}$ & $\begin{array}{l}\text { Plume } \\
\text { size, } \\
\text { mi }^{2}\end{array}$ & $\begin{array}{l}\text { Ground- } \\
\text { water } \\
\text { velocity, } \\
\text { ft/d }\end{array}$ & $\begin{array}{c}\text { Average } \\
\mathbf{f}_{\mathrm{oc}}\end{array}$ & $\mathbf{R}_{\mathbf{f}}$ & $\begin{array}{l}\text { Apparent-loss } \\
\text { coefficients (k), } \\
\text { in years }\end{array}$ & $\begin{array}{l}\text { 1st order biodegradation- } \\
\text { rate constants ( } \Xi \text { or } \mathrm{k}), \\
\text { in years }\end{array}$ \\
\hline Savage, N.H. & PCE & This report & $\begin{array}{l}\text { Glacial sand } \\
\text { and gravel with } \\
\text { underlying till }\end{array}$ & 0.5 & 2 & 0.0001 & 2.5 & $\begin{array}{l}-0.06 \\
\text { (method = transect } \\
\text { comparison from } 1995 \\
\text { field data) }\end{array}$ & -- \\
\hline $\begin{array}{l}\text { Picatinny } \\
\text { Arsenal, N.J. }\end{array}$ & TCE & 1 & $\begin{array}{l}\text { Glacial sand } \\
\text { with silt lenses }\end{array}$ & .05 & 1 & .015 & 3.5 & $\begin{array}{l}-0.016 \text { to }-0.036 \\
\text { (method = well compar- } \\
\text { ison along flow path) }\end{array}$ & $\begin{array}{l}\mathrm{k}=-0.021 \text { to }-1.82 \\
\text { (method = lab anaerobic } \\
\text { microcosm experiments). }\end{array}$ \\
\hline $\begin{array}{l}\text { Dover Air } \\
\text { Force Base, } \\
\text { Del. }\end{array}$ & PCE & 2 & $\begin{array}{l}\text { Coastal Plain } \\
\text { sediments }\end{array}$ & 1 & .5 & -- & -- & -- & $\begin{array}{l}\Xi=-0.32 \\
\text { (method = Buscheck and } \\
\text { Alcantar, 1995). }\end{array}$ \\
\hline \multirow[t]{2}{*}{$\begin{array}{l}\text { Aberdeen } \\
\text { Proving } \\
\text { Grounds, Md. }\end{array}$} & PCA & 3 & $\begin{array}{l}\text { Peat and clay } \\
\text { wetlands }\end{array}$ & .2 & $<.1$ & .02 & 10 & -- & $\begin{array}{l}\mathrm{k}=-16 \text { to }-115 \\
\text { (method = lab anaerobic } \\
\text { microcosm experiments). }\end{array}$ \\
\hline & $\begin{array}{l}c i s-1,2 \\
\text { DCE }\end{array}$ & & & -- & -- & -- & 6 & -- & $\begin{array}{l}\mathrm{k}=-18 \text { to }-33 \\
\text { (method = aerobic micro- } \\
\text { cosm experiments). }\end{array}$ \\
\hline $\begin{array}{l}\text { St. Josephs, } \\
\text { Mich. }\end{array}$ & TCE & 4 & Glacial sand & .06 & $1-2$ & .001 & 1.7 & $\begin{array}{l}-0.38 \text { to }-1.3 \\
\text { (method }=\text { transect } \\
\text { comparison) }\end{array}$ & $\begin{array}{l}\Xi=-0.602 \\
\text { (method = Buscheck and } \\
\text { Alcantar, 1995). }\end{array}$ \\
\hline
\end{tabular}

\footnotetext{
${ }^{6}$ Imbrigiotta and Ehlke (1999).

${ }^{7}$ Ellis (1996).

${ }^{8}$ Lorah and others (1997).

${ }^{9}$ Wilson and others (1994).

${ }^{10}$ Saleem (1999).
} 


\section{Simulation of Solute Transport of Tetrachloroethylene}

Solute transport of PCE was simulated by use of the computer code MOC3D (Konikow and others, 1996). MOC3D solves the three-dimensional (3-d) solute-transport equation by use of method of characteristics. The transport model is integrated with MODFLOW, a 3-d ground-water-flow model (McDonald and Harbaugh, 1988; Harbaugh and McDonald, 1996a and b). MOC3D uses the velocity fields generated by MODFLOW to solve for the transport of a single solute. Selective runs used the computer codes MODFLOW-96 (Harbaugh and McDonald, 1996a and b), MODFLOW-2000 (Harbaugh and others, 2000), and MF2K-GWT (an upgraded version of MOC3D).

The 3-d solute-transport equation that is solved by MOC3D describes the accumulation or loss of a solute over time from advection, dispersion, fluid sources, retardation, and decay as

$$
\frac{\partial C}{\partial t}+\frac{V_{i}}{R_{f}} \frac{\partial C}{\partial x_{i}}-\frac{1}{\varepsilon R_{f}} \frac{\partial}{\partial x_{i}}\left(\varepsilon D_{i j} \frac{\partial C}{\partial x_{j}}\right)-\frac{\sum\left[W\left(C^{\prime}-C\right)\right]}{\varepsilon R_{f}}+\lambda C=0,
$$

where

$$
\begin{aligned}
C & =\text { concentration, } \\
V & =\text { velocity of water, } \\
R_{f} & =\text { retardation factor (linear sorption), } \\
D & =\text { dispersion tensor, } \\
W & =\text { fluid source rate, } \\
x & =\text { direction along } x \text {-axis, } \\
t & =\text { time, } \\
\lambda & =\text { decay rate, }
\end{aligned}
$$

and

$$
\varepsilon \quad=\text { porosity (also used). }
$$

As shown previously above, equation 2 simulates a single species (for example, PCE) and cannot simulate the degradation of a single species into daughter products. In this study, decay is used to simulate irreversible reaction processes of degradation and volatilization of PCE. Dispersion terms and decay are assumed constant over the area of simulation. Retardation and porosity can vary by model layer.

\section{Construction of Solute-Transport Models}

The finite-difference ground-water-flow model (plate 4), which was constructed for the western half of the MSGD aquifer (Harte and others, 1999) and covers the Savage site, was used as a basis for PCE solute-transport simulations. A detailed description of the flow model is described in Harte and others (1999) and limited description is provided in this report.
The areal extent of the simulated ground-water-flow system is the river-valley aquifer of the western half of the MSGD aquifer. The vertical extent or upper and lower boundaries of the flow model are the water-table surface and bedrock surface, respectively (fig. 6). The water-table surface is a specified recharge boundary. The bedrock surface is a no-flow boundary. Recharge spatially is varied to simulate upland recharge from adjacent hillsides and to simulate ephemeral streams that recharge the aquifer. Perennial streams are simulated with the river package of MODFLOW (McDonald and Harbaugh, 1988; Harbaugh and McDonald, 1996a). All streams are incised partially and are simulated in model layer 1 . Wells are simulated with the well package of MODFLOW. The model grid contains over 33,000 cells in five model layers. All model layers slope parallel to an unstressed (pre-withdrawal) water-table surface and typically span 5 to $20 \mathrm{ft}$ in thickness. In each model layer, hydraulic conductivity is grouped into zones of similar values. Each zone is assigned a constant value of horizontal and vertical hydraulic conductivity. Horizontal hydraulic conductivity is specified directly but vertical is assigned as a ratio of the horizontal value. All layers have a minimum of two zones of hydraulic conductivity. Storage values and porosity are constant within each model layer.

A major consideration in the simulation of solute transport is model-grid size. The solution of solute transport is more sensitive to grid size and variations in grid size than the solution of ground-water flow primarily because numerical dispersion of solute transport and mass-balance computations are affected by variations in grid size. The finite-difference grid varies in size from $50 \mathrm{ft}$ ( $x$-direction) by $25 \mathrm{ft}$ ( $y$-direction) near OU1 to 100 $\mathrm{ft}$ ( $x$-direction) by $200 \mathrm{ft}$ ( $y$-direction) away from the VOC plume (plate 4). Cell size in the $x$-direction crosses model columns from southwest to northeast. Cell size in the $y$-direction crosses model rows from northwest to southeast. A 50 - by $25-\mathrm{ft}$ cell size spans rows 53 to 140 of the model. A subgrid, which is a part of the flow-model grid, is used in MOC3D to solve for solute transport. Two solvers in MOC3D, including the original solver (Konikow and others, 1996), require a constant grid size. Most of the simulations of PCE in this report were performed with a subgrid with cells of uniform size (plate 4). However, an expanded subgrid spanning from row 23 to 140 also was used in selected simulations with a recently developed solver (Heberton and others, 2000).

\section{Solute-Transport Parameters}

The solution of the solute-transport equation 2 requires specification of dispersivity, retardation, decay rates, and porosity. Values of dispersivity, retardation, and decay (irreversible reactions) for the Savage site are discussed in the following subsections. Porosity (total) was specified as a uniform value per model layer; values ranged from 0.3 to 0.35 . 
Dispersivity

Dispersivity is a factor used to describe dispersion (spread) of a solute around the average flow of the solute. Dispersion of a solute is computed from molecular diffusion, the dispersivity of the aquifer, and the velocity of ground water in the equation

$$
D_{i j}=\alpha_{i j m n} \frac{V_{m} V_{n}}{|V|}+D_{m} .
$$

where

$$
\begin{array}{cc}
\alpha_{i j m n} & =\begin{array}{c}
\text { component of the dispersivity ten- } \\
\text { sor }(L), \text { a fourth rank tensor; }
\end{array} \\
V_{m} \text { and } V_{n} \quad=\begin{array}{c}
\text { components of the velocity vector } \\
\text { in the } m \text { and } n \text { directions, }
\end{array} \\
\text { respectively; } \\
|V| \quad=\text { the magnitude of velocity }
\end{array}
$$

and

(Konikow and others, 1996);

$D_{m} \quad=$ effective coefficient of molecular diffusion.

In this report, dispersivity includes mechanical and enhanced (additional) dispersivity from transient flow. No molecular diffusion is simulated. Mechanical dispersivity is controlled by the grain sorting and tortuosity of the aquifer. Field measurements of mechanical dispersivity were not made but assigned on the basis of literature values (Gelhar and others, 1985, 1992). For the observed size of the plume (as measured by the length of the plume from the source area in OU1 to the $10 \mathrm{ppb}$ contour as of 1995), the longitudinal dispersivity can range from 18 to $180 \mathrm{ft}$. The transverse dispersivity is typically 0.1 of the longitudinal dispersivity and the vertical dispersivity is typically 0.01 of the longitudinal dispersivity. These relations between plume length, longitudinal dispersivity, and transverse and vertical dispersivities were used to assign parameter values of dispersivity for the solute-transport simulation of PCE.

Enhanced dispersivity from transient flow is caused by variations in velocity of ground water from a steady-state-flow condition. The combined effect of mechanical dispersivity and enhanced dispersivity leads to apparent dispersivity (Goode and Konikow, 1990). Apparent dispersivity was computed from a study of seasonal variations in ground-water flow by use of advective-transport modeling (data on file at the New Hampshire-Vermont District office, Pembroke, N.H.). The values obtained were incorporated into the dispersivity term to help account for directional variations in flow that are associated with seasonal and short term (less than a week) recharge and discharge conditions. Results showed that the apparent transverse dispersivity can be as much as one-fourth (instead of onetenth) of the apparent longitudinal dispersivity.

\section{Retardation}

Retardation was calculated on the basis of reported values of PCE partitioning between sorbed and dissolved states and carbon content of unconsolidated sediments detected in a test drilling program for OU1 (Camp, Dresser, and McKee, Inc., 1996, tables 2 and 3). The retardation factor can be estimated from the following equation for linear sorption as

$$
R_{f}=1+\left(p_{b} \times K_{d}\right) / n .
$$

$$
\begin{aligned}
& R_{f} \quad=\text { retardation factor; } \\
& p_{b} \quad=\text { bulk dry mass density of the sediments, } \\
& \text { in grams per cubic centimeter; } \\
& n=\text { porosity; }
\end{aligned}
$$

The distribution coefficient $\left(K_{d}\right)$ is determined from the partition coefficient $\left(K_{O c}\right)$ and the mass fraction of unconsolidated sediments that consists of organic carbon $\left(f_{o c}\right)$, as shown in the equation

$$
K_{d}=f_{o c}\left(K_{o c}\right) .
$$

It is assumed in equation 5 that sorption is due only to the amount of organic carbon found on the surfaces of unconsolidated sediments and is not applicable for low values of $f_{o c}$ (less than 0.0001), where sorption may be controlled by inorganic mineral surfaces (Zheng and Bennett, 1995, p. 71).

The $f_{o c}$ for the unconsolidated sediments is 0.00062 (approximately 0.001) as determined from the mean $f_{o c}$ from 20 samples (Camp, Dresser, and McKee, Inc., 1996, tables 2 and 3 ). Ranges of $f_{o c}$ from several studies are listed in Zheng and Bennett (1995, tables 9-5, p. 251). From sites with glaciofluvial and lacustrine deposits, $f_{o c}$ values range from 0.00017 (medium sand) to 0.01 (silty sand). The value from this study (0.00062) is within these reported ranges.

The $K_{o c}$ for PCE as reported by Chiou and others (1979) is $210 \mathrm{~cm}^{3} / \mathrm{g} . K_{o c}$ values greater than $210 \mathrm{~cm}^{3} / \mathrm{g}$ have been reported in the literature, but a value of $210 \mathrm{~cm}^{3} / \mathrm{g}$ was assumed to be representative of conditions in the MSGD aquifer (C.T. Chiou, U.S. Geological Survey, oral commun., 1998). 
The base $K_{d}$ (most likely value) is $0.21 \mathrm{~cm}^{3} / \mathrm{g}$, which is obtained from the relation: $K_{d}=210 \mathrm{~cm}^{3} / \mathrm{g} \times(0.001)=$ $0.21 \mathrm{~cm}^{3} / \mathrm{g}$. Substituting the $K_{d}$ into the retardation equation 4 and assuming $n=0.3$ and $p_{b}=1.86 \mathrm{~g} / \mathrm{cm}^{3}$ (both typical values for materials in the MSGD aquifer); then

$$
R_{f}=1+\left(p_{b} \times K_{d}\right) / n=2.3,
$$

where an $R_{f}$ of 2.3 represents the most likely value of $R_{f}$ for PCE solute transport at the Savage site.

\section{Irreversible Reactions}

Irreversible reactions of PCE, in the form of a first-order decay, are used to simulate processes of chemical degradation, either biotically or abiotically, and volatilization. At the Savage site, limited degradation (equivalent to a large decay half-life of at least 10 years) may occur from aerobic cometabolism or anaerobic biotransformation of PCE to TCE and then to DCE - the anaerobic biotransformation process can produce three isomers of DCE, 1,1-DCE, cis-1,2-DCE, and trans-1,2DCE (Weaver, Wilson, and Kampbell, 1997). Transformation beyond DCE to vinyl chloride, ethane, or ethene has generally not been detected at the Savage site as of 2000. Overall, degradation processes are difficult to quantify because of the transient nature of the plume and lack of data on conservative (nonreactive) tracers to understand trends in contaminant

concentrations. Furthermore, TCE and cis-1,2-DCE are potentially co-contaminants (introduced into the waste stream at the source area) and not derived (degraded) from PCE.

The simplest, most visible indicator of degradation is the relative decrease of parent concentration (PCE) and increase in daughter concentration (TCE and cis-1,2-DCE) from upgradient to downgradient areas of the plume. Observations of parent and daughter concentration ratios from OU1 to downgradient areas in OU2 show small increases from 0.10 to 0.16 in daughter products along the northern part of the plume but negligible changes along the southern part of the plume. The lack of increases in relative concentration of daughter compounds indicates either negligible degradation or similar degradation rates for all three compounds (PCE, TCE, and cis-1,2-DCE).

The apparent-loss coefficient for the VOC plume at the Savage site can be used as an upper limit to degradation rates. An apparent-loss coefficient of -0.06 per year or a half-life of 10.5 years was calculated. With a half-life of 10.5 years, and conservative travel times in the plume of 5-15 years (retarded travel times of 10-30 years), approximately one-fourth of the PCE mass or approximately 450,000 $\mathrm{g}$ (on the basis of 1995 concentrations) could be degraded (maximum degradation rate) before the plume discharges to the river.
Volatilization of PCE occurs from diffusion across the water table. Estimates of volatilization were assumed to be consistent with the reported rates of TCE volatilization at the USGS Toxic Waste Research Site at Picatinny Arsenal, N.J. (Imbrigiotta and Martin, 1996). That study reported a TCE volatilization rate of $0.1 \mathrm{mg} / \mathrm{s}(0.0036 \mathrm{Mg} / \mathrm{yr})$.

\section{Numerical Solvers and Accuracy}

Proper solution of numerical models of flow and transport are important in any simulation. For this study, solution of ground-water flow was done with the preconditioned conjugate-gradient solver (PCG2) (Hill, 1990). The solver calculates iteration parameters internally within the program instead of manually being inputted by the user. For all simulations described in this report, the modified Cholesky method, an option available in PCG2, was used. Head (water-level) residuals were solved to 0.0001 -foot precision.

MODFLOW displays information on volumetric groundwater-flow budgets in two forms, cumulative volume and volumetric rates. The percent discrepancy between inflows and outflows is an indication of numerical accuracy of the solution. The percent discrepancy for all simulations was from 0 to 0.01 percent.

For solutions without simulation of solute transport (simulations of ground-water flow only), model cells were allowed to rewet every 20th iteration if cells went dry in an earlier iteration. A description of the rewetting option of MODFLOW is discussed in McDonald and others (1991). During the steady-state pre-remedial and transient remedial simulations, a total of seven cells went dry, all located along the northwestern border of the MSGD aquifer, west of New Hampshire State Fish Hatchery withdrawal well number 5 (well number 208, fig. 2). These cells remained dry and did not rewet even though the total number of iterations exceeded 20. For solutions with solute transport that is simulated in addition to flow, rewetting is not allowed and, therefore, the cells remain inactive. Because no cells rewetted for flow solutions, no differences in results occur with the rewetting option.

There are three main solution methods for MOC3D. These include (1) an explicit finite-difference method, which is the original solution method documented in Konikow and others (1996); (2) an implicit finite-difference method, called MOCIMP (Kipp and others, 1998); and (3) ELLAM, an implicit solution using an integral formulation of conservation of mass (Heberton and others, 2000). All three solutions use method of characteristics (MOC) to solve for the advection term of the solute-transport equation, but use different methods to solve for the dispersive-diffusive term of the solute-transport equation. The explicit finite-difference method is the most restrictive because stability criteria may limit time increments (discretization) during the solution. The implicit methods are unconditionally stable (MOCIMP and ELLAM). ELLAM allows the inclusion of variable grid sizes within the domain of the solute-transport subgrid. A large subgrid with variable grid sizes was used for 
the pre-remedial simulation, which allowed for the simulation of PCE solute transport toward the two State Fish Hatchery withdrawal wells. The transport subgrid ranged from row 23 to 140 of the flow grid for the ELLAM solution, and row 53 to 140 for the explicit and MOCIMP solutions.

MOC3D displays cumulative chemical budgets for solutetransport simulations. The numerical accuracy of the solution is determined by the mass residual and percent discrepancy relative to the predominant process during the simulation. The mass residual is determined from the difference between the change in mass, or the initial dissolved and sorbed mass minus the final dissolved and sorbed mass, and total mass flux from the individual simulated processes. All simulations had a mass residual less than $30,000 \mathrm{~g}$ or $0.03 \mathrm{Mg}$. The percent discrepancy is determined, depending on the predominant process during the simulation, either as a (1) function of mass inflows, (2) mass outflows, or (3) change in mass stored.

Three types of simulations were analyzed in this report; the historical simulations from 1950 to the early 1990s, the preremedial simulations from 1995 to 1998, and the post-remedial simulations from 1998 to 2000. The historical and post-remedial simulations were run in transient mode with various stress periods. The pre-remedial was run in steady state with only one stress period. For the historical simulation, the percent discrepancy was calculated in relation to mass flux into the aquifer. The percent discrepancies were less than 15 percent. For the preremedial simulation, the percent discrepancy was calculated in relation to initial mass stored. Percent discrepancies were typically less than 1 percent. For the post-remedial simulation, the percent discrepancy was calculated in relation to mass flux out. Percent discrepancies were typically less than 3 percent, but during the early time periods of the simulations, some percent discrepancies exceeded 20 percent. According to Konikow and others (1996):

\begin{abstract}
"Because the solute-transport equation is more difficult to solve than the flow equation, the massbalance error for a solute is often greater than for the fluid. Also, because the particles that represent advection in the method of characteristics are discrete in nature and because the concentrations tracked on particles are translated to the finitedifference nodes for the purpose of computing the mass balance, the mass-balance error will typically show an oscillatory response over time. However, this error is not a cumulative type of error; it is usually largest for the first few time increments and then tends to balance out over time. As long as the oscillations remain within a steady range, not exceeding about +10 percent as a guide, then the error probably does not represent a bias and is not a serious problem."
\end{abstract}

In the post-remedial simulation, the solute budget of the early stress periods (time) had relatively large percent discrepancies exceeding 10 percent but due to the small time increments during those early periods, the relatively large percent discrepancy was not critical to the reliability of the simulation. Generally, the early stress periods had time increments less than 1 month, which constrained the amount of changes in mass. For example, changes in mass during the early periods of the postremedial simulation generally were less than $0.005 \mathrm{Mg}$ or $5 \mathrm{Kg}$.

Various identical runs were made with multiple solvers on an identical simulation of remedial conditions. Results indicate that the implicit solution (MOCIMP) produced the smallest percent discrepancy. After 5-10 years, the MOCIMP solution had a 0.5-percent discrepancy, the explicit solution had a 2-percent discrepancy, and ELLAM solution had 11.5-percent discrepancy. For this reason, the ELLAM solution was not used in the final remedial simulation.

\section{Evaluation of Solute-Transport Models}

Models were calibrated for each of the three simulation periods: (1) the historical evolution of PCE distribution from the first introduction of PCE into the MSGD aquifer (approximately 1960) to the 1990s, (2) a pre-remedial system from 1995 to 1998, and (3) a remedial (post barrier) system from 1998 to 2000. Whenever possible, both PCE concentrations and ground-water heads were used in the calibration if data were available.

\section{Historical Simulation}

A two-dimensional (2-d) transient solute-transport model was constructed to simulate the long-term evolution, from 1950 to the early 1990s, of the distribution of PCE in the overburden. A 2-d solute model was used for this period because it allowed for quick simulation times and provided adequate spatial coverage given the lack of vertical information on the plume during the simulation period. Plume growth is simulated with a starting PCE mass of zero (no PCE in the overburden) at the start of the simulation (time $=0$ ) but a constant rate of PCE input is applied to the OU1 area after the start of the simulation. As part of the calibration process, computed PCE concentrations were compared to the observed PCE concentrations for the year 1989, when the plume distribution was first mapped in detail.

Although PCE concentrations were calibrated against 1989 values, it was necessary to calibrate hydraulic head and flow (river seepage) data against 1994-95 values because flow data were unavailable for 1989.

The 2-d transport model utilizes a 2-d flow model that was simplified from the 3-d flow model constructed by Harte and others (1999). The hydraulic conductivity of the 2-d model was computed from the bulk transmissivity of the 3-d model divided by the saturated thickness of the MSGD aquifer. Within the plume area, the hydraulic conductivity averages about $150 \mathrm{ft} / \mathrm{d}$. Other model-input parameters, such as rates of recharge and head boundaries, were kept the same between the 2-d and 3-d models. A specific yield of 0.23 (Harte and others, 1999) was assigned to the model (a secondary storage coefficient is not simulated in the 2-d model). The river boundary was adjusted in 
the 2-d model from the initial 3-d model because the initial 2-d model results showed higher rates of river seepage than rates in the 3-d model. The difference in amounts of river seepage is caused when a partially penetrating river is simulated in a $2-d$ flow model. To decrease river seepage in the 2-d model to match the 3-d calibrated model, riverbed hydraulic conductance was decreased to half the value specified in the 3-d model.

The simulated long-term flow conditions used in the historical calibration follows flow conditions described and simulated in Harte and Willey (1997). Flow and transport were simulated from as early as 1950 to as late as 1994, and incorporated the variable patterns of ground-water withdrawals in the aquifer (appendix 2) that led to an increased transverse distribution of the VOC plume in the MSGD aquifer. The pattern (amount and distribution) of withdrawals has changed dramatically over the years as withdrawals have increased from the south to the north side of the Souhegan River. A total of 12 stress periods were used to simulate the variable rates of withdrawals in the aquifer.

\section{Ground-Water Flow}

Ground-water-head data are unavailable for the historical calibration. Instead, a simulation of 1994-95 steady-state conditions was used as a calibration check of the 2-d model. A listing of key calibration statistics is given in table 4 for the 2-d model and previously calibrated 3 -d model for the calibrated flow period (1994-95 steady-state conditions). Computed flows and heads are similar to observed flows (river seepage) and heads. The standard mean error between computed heads and observed heads is $-0.41 \mathrm{ft}$ for the $2-\mathrm{d}$ model and $-0.11 \mathrm{ft}$ for the 3-d model. River seepages are also comparable, although outflow for the 2-d model is less than the 3-d model.

Advective transport of ground-water particles (15 total) from three locations in OU1, which were known areas of contaminant entry ways into the aquifer (Camp Dresser and McKee, Inc., 1996), were forward tracked to their final discharge locations in the 2-d and 3-d models for the 1994-95 steady-state simulation. Results from this tracking indicate that the advective transport (path and travel times) of the groundwater particles is similar between the 2-d and 3-d models for the simulated 1994-95 steady-state flow conditions (table 4). The direction of transport corresponds to those shown in Harte and others (1999, fig. 14 , p. 29) and shows that particles from the northernmost input location discharge to the State Fish Hatchery well, and the particles from the two southernmost point locations discharge to the Souhegan River. The average travel times of the 15 particles varied by less than 10 percent. However, the maximum travel times of particles from the 2-d model are approximately half of the times from the 3 - $d$ model. Consequently, the use of the 2-d model in historical calibration will provide an adequate approximation of the average contaminant distribution but may overpredict contaminant transport in some areas of the plume. During calibration, this bias could result in selection of a high retardation factor, so as to slow transport, or a high irreversible reaction rate (decay half-life), so as to induce additional loss of solute.
Table 4. Results of two-dimensional and three-dimensional steady-state models (ground-water-flow budgets, head residuals, travel times from advective transport and river seepage) Savage Municipal Well Superfund site, Milford, N.H.

[All units in cubic feet per second unless noted; subbasin river zones shown in plate $1 ;--$, no data]

\begin{tabular}{|c|c|c|c|}
\hline \multirow[b]{2}{*}{ Parameter } & \multicolumn{2}{|c|}{$\begin{array}{c}\text { Simulated ground-water } \\
\text { budget }\end{array}$} & \multirow{2}{*}{$\begin{array}{c}\text { Observed } \\
\text { measurement } \\
(1988)\end{array}$} \\
\hline & $\begin{array}{c}\text { Two- } \\
\text { dimensional } \\
\text { model }\end{array}$ & $\begin{array}{c}\text { Three- } \\
\text { dimensional } \\
\text { model }\end{array}$ & \\
\hline \multicolumn{4}{|c|}{ Inflow } \\
\hline Recharge & 3.30 & 3.26 & -- \\
\hline $\begin{array}{l}\text { Eastern general-head } \\
\text { boundary }\end{array}$ & .53 & .68 & -- \\
\hline Wells & 0 & 0 & -- \\
\hline River seepage & 3.57 & 3.26 & -- \\
\hline \multicolumn{4}{|c|}{ Outflows } \\
\hline $\begin{array}{l}\text { Eastern general-head } \\
\text { boundary }\end{array}$ & 0.14 & 0.09 & -- \\
\hline Wells & 4.18 & 4.18 & -- \\
\hline River seepage & 3.08 & 3.63 & -- \\
\hline \multicolumn{4}{|c|}{$\begin{array}{l}\text { Ground-water head residuals } \\
\text { (72 wells total) }\end{array}$} \\
\hline $\begin{array}{l}\text { Absolute mean error, } \\
\text { in feet }\end{array}$ & 0.71 & 0.58 & -- \\
\hline $\begin{array}{l}\text { Standard mean error, } \\
\text { in feet }\end{array}$ & -.41 & -.11 & -- \\
\hline \multicolumn{4}{|c|}{ Travel times from ${ }^{1}$ OU1 wells } \\
\hline Mean, in years & 5.22 & 5.73 & -- \\
\hline Maximum, in years & 6.07 & 11.73 & -- \\
\hline Minimum, in years & 4.36 & 2.98 & -- \\
\hline Basin & \multicolumn{3}{|c|}{$\begin{array}{c}\text { Subbasin river seepage } \\
\text { (Subbasins shown on plate 1) }\end{array}$} \\
\hline 2 & 0.11 & 0.28 & -0.18 \\
\hline 3 & .18 & .25 & .05 \\
\hline 4 & 1.3 & 1.42 & 1.58 \\
\hline 5 & -.62 & -.67 & -.27 \\
\hline 6 & 1.31 & 1.21 & -.73 \\
\hline 7 & -.03 & -.03 & -- \\
\hline 8 & -.024 & -.05 & -.31 \\
\hline 9 & -.18 & -.35 & -.47 \\
\hline
\end{tabular}

\footnotetext{
${ }^{11}$ See figure 3 for forward tracking locations corresponding to known contaminant-disposal location.
}

The model-computed historical ground-water-flow budget shows that no appreciable storage depletion occurs in the aquifer from increases in ground-water withdrawals; however, increases in withdrawals are augmented by increases in induced 
river seepage and a reduction in ground-water discharge to the river. Ground-water withdrawals have increased from negligible amounts (circa 1960) to $4.5 \mathrm{ft}^{3} / \mathrm{s}$ in the 1990s. As a result, river seepage (river recharge) increased from 1 to $3.5 \mathrm{ft}^{3} / \mathrm{s}$ and ground-water discharge to rivers decreased from 4.5 to $3 \mathrm{ft}^{3} / \mathrm{s}$. Besides the increased withdrawals, the variations in patterns of withdrawals, which have decreased along the southern part of the plume and increased along the northern part of the plume (Harte and Willey, 1997), have increased the lateral (transverse) dispersion of the plume.

\section{Solute Transport}

The 2-d solute-transport model is simulated within a subgrid of the flow model. The subgrid is from rows 53 to 140 and columns 25 to 170, which corresponds to a uniform grid area ( $25 \mathrm{ft}$ by $50 \mathrm{ft}$ ) of the flow model. Because the boundaries of the subgrid are in the flow model, there is no affect on the computation of ground-water flow. Solute transport out of the subgrid boundaries also is unaffected. Solute transport into the subgrid boundary is assigned a background concentration of $0 \mathrm{ppb}$.

PCE-contaminant loads were input into the model at the three locations in OU1 that match known areas of contaminant entryways into the aquifer, coinciding with the same point locations tracked with ground-water particles. Simulated PCE enters the aquifer with recharge at constant concentrations for the duration of the simulated period. Therefore, PCE input is distributed by recharge alone in the source area, which is an oversimplication because the model does not account for PCE disbursal by density-driven flow. Fortunately for 2-d transport, vertical transport is not simulated. Another oversimplification is the simulation of all PCE input and contamination from one facility (OK Tool) in the aquifer. Inputs of contamination from multiple facilities throughout the southern part of the plume were possible during the simulated time period; therefore, contamination may be underestimated in the transport model along the southern part of the plume. Lastly, input and(or) dissolution of PCE from a separate phase liquid (for example, DNAPL) into a solute in ground water probably occurred at variable rates during the simulation period. Uniform rates were assigned in the model to simplify the analysis.

Solute-transport parameters tested include retardation, which simulates linear-equilibrium sorption; an irreversible reaction term (in the form of first-order decay rate), to simulate processes such as degradation and volatilization; and dispersivity, which simulates the spreading of the solute around the average solute transport. Dispersivity includes a longitudinal and transverse component for the historical 2-d model.

Various rates of PCE source input were applied to the three OU1 locations (fig. 3, known contaminant disposal locations) and computed PCE concentrations were compared to observed PCE concentrations from wells in the OU1 area (table 5) so as to determine appropriate rates of PCE mass input for subsequent simulations. Adjustments of mass input rates had the largest effect on computed concentrations in the OU1 area.
PCE concentrations in OU1 are highly correlated and sensitive to adjustments in source input rates. The rate of applied mass input of PCE in OU1 in relation to the mean concentration of model-computed PCE concentrations at three well locations (HM-1, MI-63, and cluster wells MW-16 A,B,C) in OU1 is shown in figure 9 . The three well sites were selected to provide sufficient transverse coverage at an optimal downgradient distance from the input source (approximately $350 \mathrm{ft}$ ) so as to allow for sufficient spreading of PCE concentrations from the input source. The correlation is extremely strong (coefficient of determination of 0.97) between the input rate and the computed concentration. In contrast, PCE concentrations in OU1 are less sensitive to adjustments in other model parameters. Ranges in the mean computed PCE concentration (17 to 2,874 ppb) from adjustment in input rates far exceeded ranges in mean computed concentration (1,263 to 1,876 ppb) from adjustments in all other model parameters. Because of these conditions, the model is considered well calibrated to mass-input rates.

For the simulations listed in table 5, all chemical and flow parameters, except mass input of PCE, were kept constant. Results show that a constant mass input rate of $1 \mathrm{~g} / \mathrm{min}$ of PCE provided the best match between computed and observed concentrations of PCE from five wells at three locations near the boundary between the OU1 and OU2 areas.

Anecdotal information on the use of PCE, both nationally and locally, was used to constrain simulated time periods. Simulated starting time periods of PCE input ranged from 1950 to 1960. Use of chlorinated organics as solvents in the United States began in the mid 1950s (Cohen and Mercer, 1993). Manufacturing operations in the OK Tool facility (OU1) began in the late 1940s but expanded in the early 1960s (Richard Goehlert U.S. Environmental Protection Agency, Region 1, written commun., 1997). Although active PCE disposal in the aquifer ceased in the mid 1980s, continued dissolution of PCE from a DNAPL or other source, such as residual liquid, has continued as a PCE source to the aquifer until the construction of the barrier wall in 1998 encircled the primary source area.

The simulated dissolved mass of PCE reaches a static level as a result of the development of a quasi steady-state system after 15 to 20 years from the start of PCE input; therefore, the initial starting date did not affect the results of the 1989 comparison. The longitudinal length of the model-computed plume is also insensitive to the start dates tested and shows no increase in the length of the plume as measured to the $10 \mathrm{ppb}$ contour for 1989.

Snapshots of simulated plume evolution through time are shown in figure 10. For this simulation, input starts at 1960 (time $=0$ ). In 5 years, from 1960 to 1965 , the $1,000 \mathrm{ppb}$ contour migrates about 1,000 ft downgradient of the OK Tool facility. During that time, only the Savage well is in operation. In the year 1974, the length of the $1,000 \mathrm{ppb}$ contour is similar to that observed in 1989. From 1965 to 1974, three additional withdrawal wells are in operation (two along the southern part of the plume and one to the north). In 1983, prior to cessation of withdrawals at the Savage well, the plume and the $1,000 \mathrm{ppb}$ contour shifts farther southward from the 1974 distribution. In 1989, the 
Table 5. Summary of mass inputs of tetrachloroethylene (PCE) for simulated historical runs that test the effects of mass loads of PCE on computed concentrations in the OU1 part of the Savage Municipal Well Superfund site, Milford, N.H.

[No., number; HIST, historical model; PCE, tetrachloroethylene; g/min, grams per minute; ppb, parts per billion; Mg, megagrams; negative number means that computed value is less than observed; all solute transport input parameters constant except mass input. Well locations are shown on plate 2]

\begin{tabular}{|c|c|c|c|c|c|c|c|c|c|}
\hline $\begin{array}{l}\text { Model } \\
\text { run No. }\end{array}$ & $\begin{array}{l}\text { Starting } \\
\text { year of } \\
\text { PCE input }\end{array}$ & $\begin{array}{c}\text { Approxi- } \\
\text { mate rate } \\
\text { of mass } \\
\text { input } \\
\text { (g/min) }\end{array}$ & $\begin{array}{c}1989 \\
\text { Computed } \\
\text { sorbed } \\
\text { mass of } \\
\text { PCE, } \\
\text { in } \mathrm{Mg}\end{array}$ & $\begin{array}{c}1989 \\
\text { Computed } \\
\text { dissolved } \\
\text { mass of } \\
\text { PCE, } \\
\text { in } \mathrm{Mg}\end{array}$ & $\begin{array}{c}\text { Difference } \\
\text { between } 1989 \\
\text { computed } \\
\text { dissolved mass } \\
\text { of PCE and } \\
\text { observed (5.7), } \\
\text { in } \mathrm{Mg}\end{array}$ & $\begin{array}{c}1989 \\
\text { Computed mean } \\
\text { concentration of PCE } \\
\text { at wells (MW16, } \\
\text { HM-1, and MI-63) at } \\
\text { downgradient edge } \\
\text { of source area, } \\
\text { in ppb }\end{array}$ & $\begin{array}{c}\text { Difference } \\
\text { between } 1989 \\
\text { computed and } \\
\text { observed mean } \\
(1,330) \text { PCE at } \\
\text { wells MW16, } \\
\text { HM-1, and MI-63, } \\
\text { in ppb }\end{array}$ & $\begin{array}{c}1989 \\
\text { Computed } \\
\text { length of } \\
\text { PCE plume, } \\
\text { in feet } \\
\text { (to } 10 \mathrm{ppb} \text { ) }\end{array}$ & $\begin{array}{c}\text { Difference } \\
\text { between } 1989 \\
\text { computed } \\
\text { and observed } \\
\text { length }(5,667) \\
\text { of PCE plume, } \\
\text { in feet } \\
\text { (to } 10 \mathrm{ppb} \text { ) }\end{array}$ \\
\hline HIST 8 & 1960 & .1 & 1.5 & .5 & -5.6 & 174 & $-1,156$ & 4,583 & $-1,084$ \\
\hline HIST 15 & 1960 & 1 & 10. & 3.3 & -2.4 & 1,250 & -80 & 5,041 & -626 \\
\hline HIST 23 & 1950 & 1 & 8.4 & 2.8 & -2.9 & 1,000 & -330 & 5,041 & -626 \\
\hline HIST 17 & 1960 & 1.7 & 19.7 & 6.5 & .8 & 2,595 & 1,265 & 5,451 & -216 \\
\hline
\end{tabular}

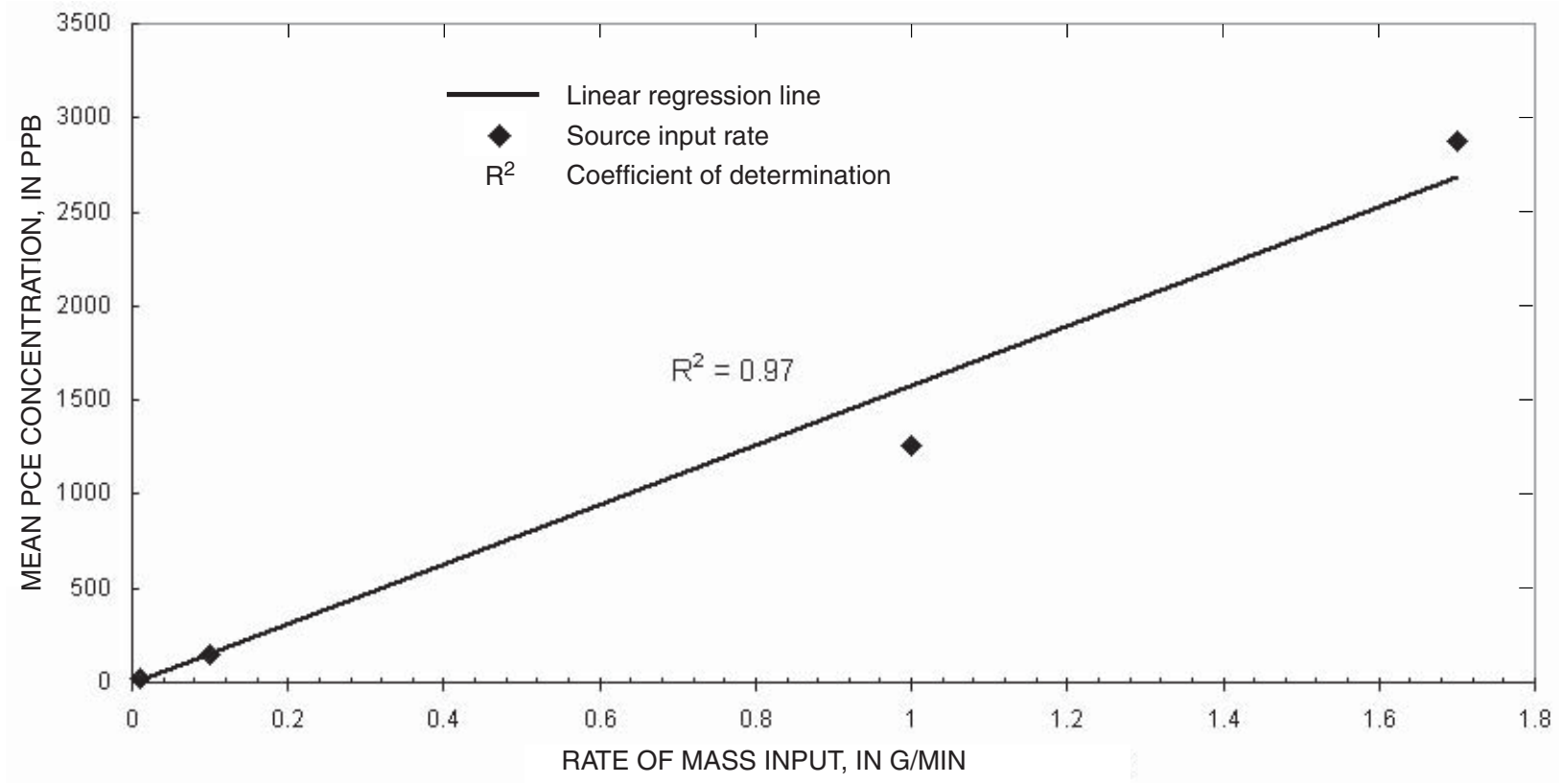

Figure 9. Rate of mass input of tetrachloroethylene (PCE) in OU1 in relation to the mean concentration of model-computed PCE concentrations from three locations in 0U1, Savage Municipal Well Superfund site, Milford, N.H. [Operable unit 1 (OU1), concentration in parts per billion (ppb), and rate of input in grams per minute $(\mathrm{g} / \mathrm{min})$.] 
A.

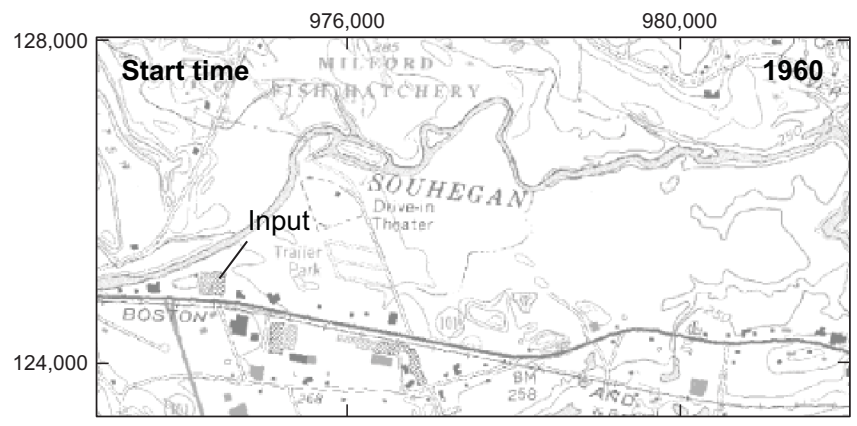

B.

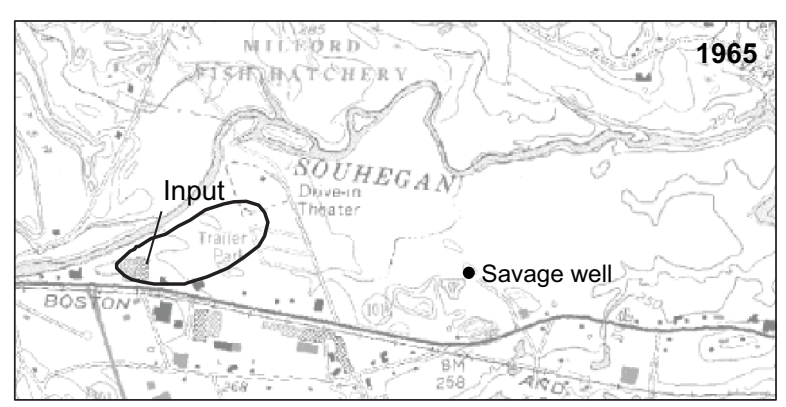

D.

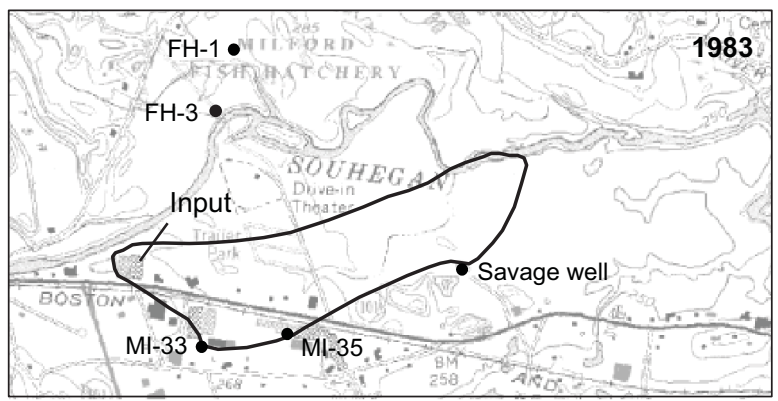

Base from U.S. Geological Survey digital raster graphics (DRG) Milford, N.H. topographic quadrangle, 1:24,000-scale, 1968, photorevised 1985 New Hampshire state plane coordinate system

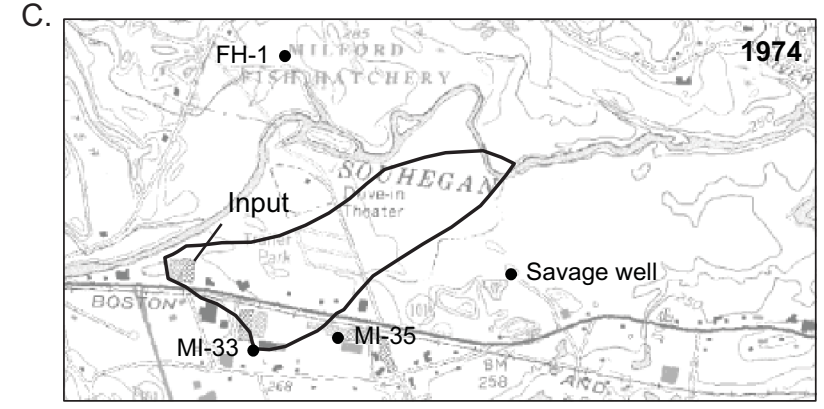

E.

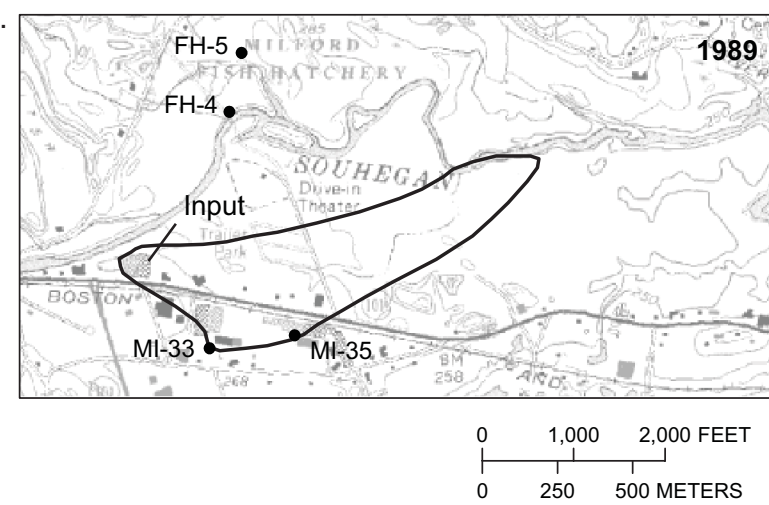

\section{EXPLANATION}

- Contour line showing

PCE concentration of 1,000 parts per billion

$\mathrm{FH}-1$

Active withdrawal well for simulation date shown

Figure 10. Contours of tetrachloroethylene (PCE) concentrations through time from two-dimensional model for (A) starting conditions in 1960, (B) 1965, (C) 1974, (D) 1983, and (E) 1989, Savage Municipal Well Superfund site, Milford, N.H. 
southernmost extent of the 1,000-ppb contour shifts northward as withdrawals decrease along the southern part of the plume, after cessation of withdrawals at the Savage well in 1983, and after a new high capacity ( $800 \mathrm{gal} / \mathrm{min})$ withdrawal well (FH-4) is placed into operation to the north of the plume (fig. 10E).

Calibration of solute-transport parameters of retardation, dispersivity, and irreversible reaction (first-order decay) was done by comparing 1989 observed concentrations to modelcomputed concentrations of PCE. Focus was placed on comparing the simulated longitudinal extent of the PCE distribution to the 1989 observed extent of the PCE distribution. The observed concentrations at cluster wells, which have individual wells grouped together with single, short-screened wells (less than $10 \mathrm{ft}$ ), were averaged to compare to computed concentrations. The observed concentrations at single long-screened wells (more than $20 \mathrm{ft}$ long) were used as is. Observed concentrations from singly located short-screened wells also were used if data from other nearby, more preferable wells were unavailable and the singly located short-screened wells were installed more than $10 \mathrm{ft}$ from the water-table surface (usually $20 \mathrm{ft}$ below land surface).

Model-computed concentration gradients from 1,000 to $100 \mathrm{ppb}$ at the leading edge of the plume are sensitive to the variations tested in retardation ( $R=2$ to 6 ) and reaction (decay half-life of 0 year (no decay can also be expressed as infinity) to 10 years). These concentration gradients are less sensitive to dispersivity (longitudinal values from 54 to $180 \mathrm{ft}$ and transverse from 6 to $18 \mathrm{ft}$ ).

Maps of the 1,000-ppb PCE-concentration contour for five model runs, and the 2-d observed maximum 1,000 ppb contour (HMM Associates, Inc., 1991) show that a retardation of 2.5 produces the best fit between modeled concentrations and observed concentrations (fig. 11). Simulations were examined using the same mass input rates and starting time but with varying values of retardation, irreversible reaction rates (decay halflife), and dispersivities. Simulations of PCE concentrations with a retardation of 4 all show a shorter longitudinal length of the 1,000 ppb contour than the observed average or maximum contours. Simulations using a retardation of 2.5 best match the observed distribution. The increase of dispersivity from 54 to $180 \mathrm{ft}$ has little effect on the $1,000 \mathrm{ppb}$ contour. In contrast, longitudinal-profile plots of concentration through a section of the aquifer (not shown in any figure) show that dispersivity affects the distribution of PCE for values less than $100 \mathrm{ppb}$.

Model-computed concentrations of PCE, from model cells coinciding with the location of an observed well(s) with available PCE data, were compared to observed concentrations. A total of 46 values were compared, and showed that the best match occurred with a low retardation $(R=2.5)$, dispersivities of 54 for the longitudinal and 12 for the transverse, and low irreversible reaction rate (half-life of 20 years and above). The standard mean errors for the two best simulations were $442 \mathrm{ppb}$ (half-life of 20 years) and 634 ppb (no decay half-life), respectively. The absolute mean errors were 867 ppb (half-life of
20 years) and $988 \mathrm{ppb}$ (no decay half-life). The root-mean of squared residuals (RMS) was 1,566 ppb ((half-life of 20 years) and 1,712 ppb (no decay half-life).

The solute-transport budget (dissolved and sorbed mass for the simulation with a half-life of 20 years) for 1988 shows that $0.02 \mathrm{Mg}$ of PCE discharges out of the subgrid area along the northern part of the plume, $0.55 \mathrm{Mg}$ discharges to wells (industrial wells MI-33, MI-35 along the southern part of the plume, fig. 10E), $0.36 \mathrm{Mg}$ discharges to the river, and $0.44 \mathrm{Mg}$ is lost by volatilization and degradation. For 1989, $0.03 \mathrm{Mg}$ of PCE discharges out of the subgrid area on the northern part of the plume, $0.32 \mathrm{Mg}$ discharges to withdrawal wells (industrial wells MI-33, MI-35 along the southern part of the plume), $0.46 \mathrm{Mg}$ discharges to the river, and $0.56 \mathrm{Mg}$ is lost by volatilization (1 percent of $0.56 \mathrm{Mg}$ lost by irreversible reaction) and degradation ( 99 percent of the $0.56 \mathrm{Mg}$ lost is by irreversible reaction). Therefore, from year to year, the solute budget will vary depending on the patterns and rates of withdrawals and probably from other stresses such as recharge and river seepage.

\section{Pre-remedial Simulation}

The pre-remedial simulation used the 3-d, steady-stateflow model described in Harte and others (1999) with the exceptions described here. The pre-remedial calibration period was from May 1995 to December 1998, when construction of the barrier wall was completed in OU1. Hydrologic conditions during the pre-remedial period were similar to, but slightly different than, the 1994-95 conditions described in Harte and others (1999).

Ground-water withdrawals varied slightly between 199598, and withdrawals increased from 1994 to 1995 rates. In 1994-95, ground-water withdrawals included the two State Fish Hatchery wells (combined withdrawal rate of $3.58 \mathrm{ft}^{3} / \mathrm{s}$ ), industrial well MI-88 $\left(0.38 \mathrm{ft}^{3} / \mathrm{s}\right)$, and a private fish hatchery $\left(0.22 \mathrm{ft}^{3} / \mathrm{s}\right)$. In 1996 , withdrawals increased at the two State Fish Hatchery wells to $4.19 \mathrm{ft}^{3} / \mathrm{s}$, stayed the same at the industrial well MI-88, and were terminated at the private fish hatchery. The location of withdrawal wells is shown in figure $2 \mathrm{~b}$ except for well MI-88, which is next to well MI-33 and supersedes this well.

The pre-remedial period was simulated as a steady-stateflow condition; storage changes in the aquifer are assumed negligible and were not simulated, and stress rates were effectively constant for the period. The assumption of steady-state conditions appears reasonable because the long-term observation well MI-18 (fig. 1) had a small $0.68 \mathrm{ft}$ drop in ground-water levels during the simulated period from May 1995 to December 1998 - less than a 20 percent difference in the total fluctuation of this well. Model-assigned recharge rates were kept constant at 1994 rates. Model-assigned withdrawals were kept at constant rates of $4.19 \mathrm{ft}^{3} / \mathrm{s}$ from the two State Fish Hatchery wells, $0.38 \mathrm{ft}^{3} / \mathrm{s}$ at MI- 88 , and $0.11 \mathrm{ft}^{3} / \mathrm{s}$ at the private fish hatchery well. 


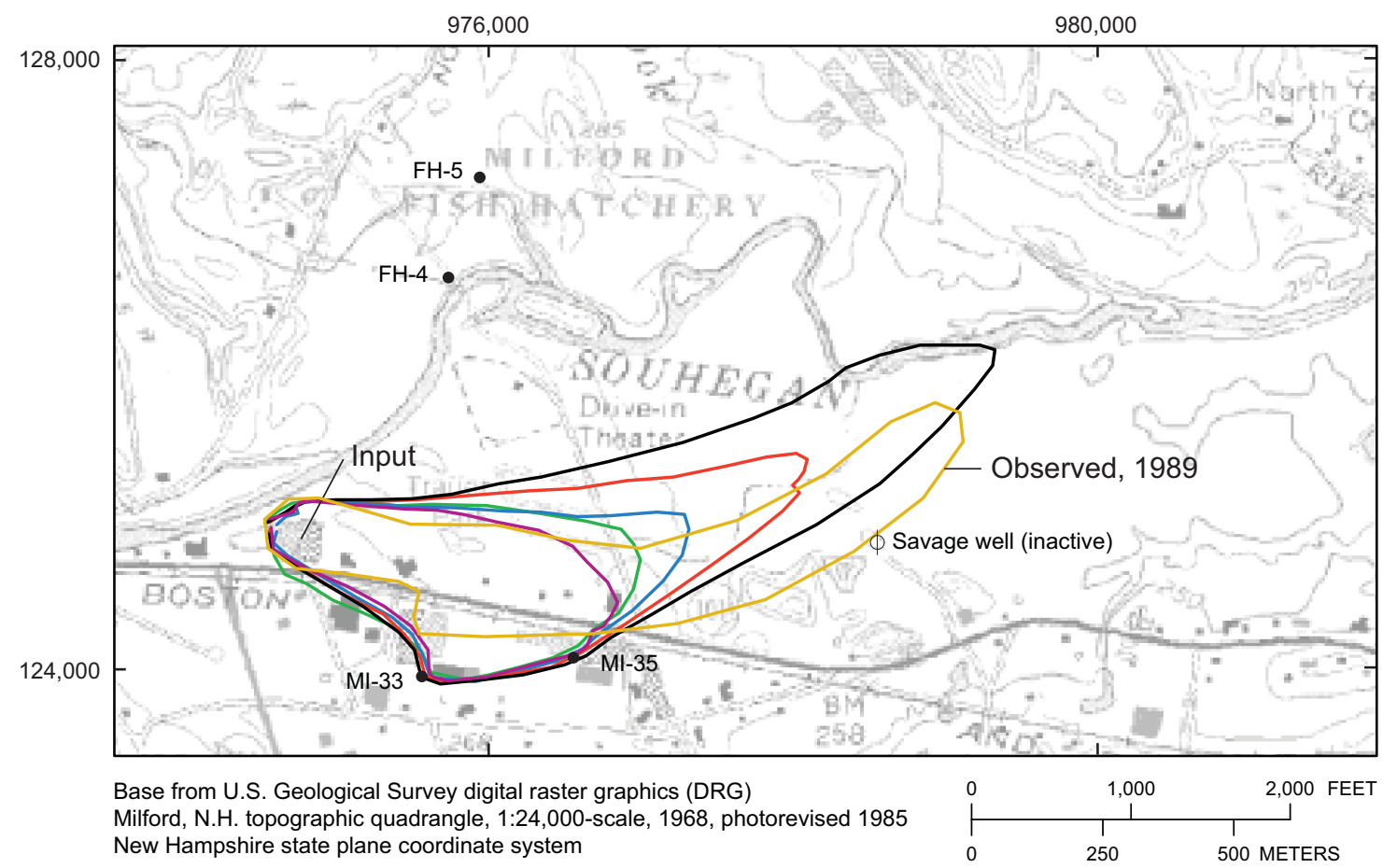

EXPLANATION

Model parameters

\begin{tabular}{|c|c|c|}
\hline $\mathrm{R}$ & Decay half- & DL/DT \\
\hline 4 & 10 & $60 / 6$ \\
\hline 4 & 20 & $54 / 12$ \\
\hline 4 & 20 & $180 / 18$ \\
\hline 2.5 & 20 & $54 / 12$ \\
\hline 2.5 & 0 & $54 / 12$ \\
\hline
\end{tabular}

Figure 11. Contours of 1,000 parts per billion (ppb) tetrachloroethylene (PCE) concentrations from observation and multiple simulations using the two-dimensional model, 1989, Savage Municipal Well Superfund site, Milford, N.H. ( $R$, retardation; $\mathrm{DL} / \mathrm{DT}$, longitudinal and transverse dispersivity.)

\section{Ground-Water Flow}

To improve the model calibration of ground-water flow and solute transport, additional boring logs and hydraulic conductivity tests from pumped wells were analyzed and modifications were made to the 3-d flow model (Harte and others, 1999). Zones of hydraulic conductivity of the aquifer were adjusted as part of the model modification, which included the following changes:

1. Extending the high hydraulic conductivity zone in layer 5 westward on the basis of borings in OU1,
2. Extending the high horizontal hydraulic conductivity of layers 2 and 3 at the State Fish Hatchery area southward by $100 \mathrm{ft}$ to incorporate the withdrawal well located closest to the Souhegan River (FH-4, fig. 2), and

3. Incorporating additional spatial variability of vertical hydraulic conductivity at and within model hydraulic conductivity zones (vertical hydraulic conductivities were initially set at a 1:1 ratio with horizontal hydraulic conductivities in the northwestern area in layers 1 and 2 by the State Fish Hatchery and by cobble zone in layer 1; elsewhere it was set at a 1:4 ratio under base values. 
During the course of model calibration for the pre-remedial and remedial models, alternative hydraulic conductivity features were tested. These features included:

4. Decreasing horizontal hydraulic conductivity in the central part of the plume in layer 2 from 250 to $86 \mathrm{ft} / \mathrm{d}$,

5. Testing the effects of varying horizontal hydraulic conductivity for layer 5 by a factor of 3 (from 5 to $60 \mathrm{ft} / \mathrm{d}$ (base values) to 15 to $180 \mathrm{ft} / \mathrm{d}$ ), and

6. Decreasing ratios of vertical to horizontal hydraulic conductivities from 1:4 to 1:8 in selected areas and layers of the model.

The test of alternative hydraulic conductivities (numbers 4-6) resulted in small changes in model-computed head for the 1995-98 steady-state simulation, which indicate the model is insensitive to these modifications for computation of head. Volumetric flow, advective transport, and solute transport are sensitive to the alternative hydraulic conductivities (numbers 4-6) tested. The computed ground-water-flow budget shows a small decrease in river seepage (about $0.4 \mathrm{ft}^{3} / \mathrm{s}$ ) with a decrease in horizontal hydraulic conductivity for layer 2 representing the upper part of the MSGD aquifer. In contrast, the flow budget is unchanged with an increase in horizontal hydraulic conductivity for layer 5 representing the lower part of the MSGD aquifer. Advective and solute-transport calibration showed that calibration improved with the inclusion in the model of the alternative hydraulic conductivities listed in numbers 4 and 6 . Based on the advective-transport analysis and solute-transport calibration, model results from simulations including these alternative values are presented in the following paragraphs.

Model-computed heads from the steady-state simulation of 1995-98 were compared to observed heads from December 1998 at 52 wells (all in the OU2 area) to evaluate model fit. Observed wells were selected for comparison only in the OU2 area because barrier-wall construction in OU1 disrupted heads locally. The standard mean error is $0.81 \mathrm{ft}$ and the absolute mean error is $0.93 \mathrm{ft}$, which indicate an overall positive bias (computed heads exceed observed heads). December 1998 heads are slightly less than average heads for the May 1995 to December 1998 period, as indicated by data from the long-term (1960 to current) water-level observation well MI-18. In December 1998, the head at well MI-18 was $255.4 \mathrm{ft}$ and the average heads for water years 1997 and 1998 were 255.9 and 255.96, respectively. The head at MI-18 in December 1998 $(255.4 \mathrm{ft})$ also was lower than the head $(255.88 \mathrm{ft})$ from 1994 to 95. Therefore, the apparent positive bias of head residuals for the December 1998 comparison may be a result of the observed December 1998 data set being slightly low for the simulated period. Nevertheless, the December 1998 data set allows for a semi-quantitative check against model accuracy for this simulation period, and is the only extensive water-level data set for the pre-remedial simulated period.

Head residuals of December 1998 from model layer 3 in the OU2 area are shown in figure 12. Head residuals for the other model layers follow a similar pattern. Computed heads exceed observed heads along the southern OU2 area east of withdrawal well MI-88. Conversely, computed heads are less than observed heads in the eastern part of the OU2 area. One potential cause of relatively high residuals compared to other areas along the southern area of OU2 may be due to unaccounted for variations in hydraulic conductivity and(or) patterns of recharge.

Model-computed heads from model layer 3 (representing the middle part of the MSGD aquifer) are shown in figure 13 for the steady-state simulation of 1995-98. Heads decrease from $264 \mathrm{ft}$ at OU1 to $242 \mathrm{ft}$ at the eastern edge of the model layer. A cone of depression is visible at the State Fish Hatchery withdrawal wells. Withdrawals here cause a divergence in flow between ground-water discharge to these wells and discharge to the Souhegan River or Purgatory Brook to the east. Withdrawals at well MI-88 cause the $260 \mathrm{ft}$ contour to bend to the west.

The model-computed ground-water-flow budget for 199598 shows that ground-water withdrawals are $3.96 \mathrm{ft}^{3} / \mathrm{s}$, river seepage into the aquifer is $3.49 \mathrm{ft}^{3} / \mathrm{s}$ and ground-water discharge to the river is $3.16 \mathrm{ft}^{3} / \mathrm{s}$ (a net loss of $0.33 \mathrm{ft}^{3} / \mathrm{s}$ ). A net inflow of $0.48 \mathrm{ft}^{3} / \mathrm{s}$ is computed at the eastern boundary of the aquifer. Flow in the aquifer occurs predominantly within the upper to middle aquifer. The model-computed budget calculates 90 percent of the flow occurs within model layers 1 through 3 .

\section{Apparent Age of Ground Water}

Conventional physical methods, such as measurement of hydraulic heads and estimation of hydraulic properties, have limitations for defining ground-water flow. The solution of the ground-water-flow equation is non-unique because physical methods cannot determine recharge rates and effects of boundary conditions on flow. Environmental isotopes (natural isotopes and anthropogenic tracers) can be used to constrain the solution of the ground-water-flow equation and provide information on flow rates when used in conjunction with physical methods described earlier.

Ground-water samples from five wells in OU1 (B95-3, B95-6, B95-8, MW-16B, and MW-16C; appendix 1, plate 2) were collected in May 1997, and samples were analyzed for tritium/helium (anthropogenic tracer) concentrations to determine the age of sampled waters. Determination of the apparent age of ground water using tritium $\left({ }^{3} \mathrm{H}\right)$ in combination with its decay product tritogenic helium $\left({ }^{3} \mathrm{He}\right)$ is referred to as the tritiumhelium isotope-dating method. High concentrations of tritium were introduced into the atmosphere from fusion-bomb testing in the 1950s and 1960s with a peak concentration in 1963. Samples also were analyzed for chlorofluorocarbons (compounds produced as a refrigerant); however, interference of contaminated waters from the solvent plume inhibited accurate age dating by this method.

Sampling methods for these environmental isotopes were similar to those described in Harte and others (2001, p. 20) for bladder-pump samples, with the exception of the specific bottle type used for each type of isotope. The bladder pump was placed at the midpoint of the well screens. Water was evacuated 


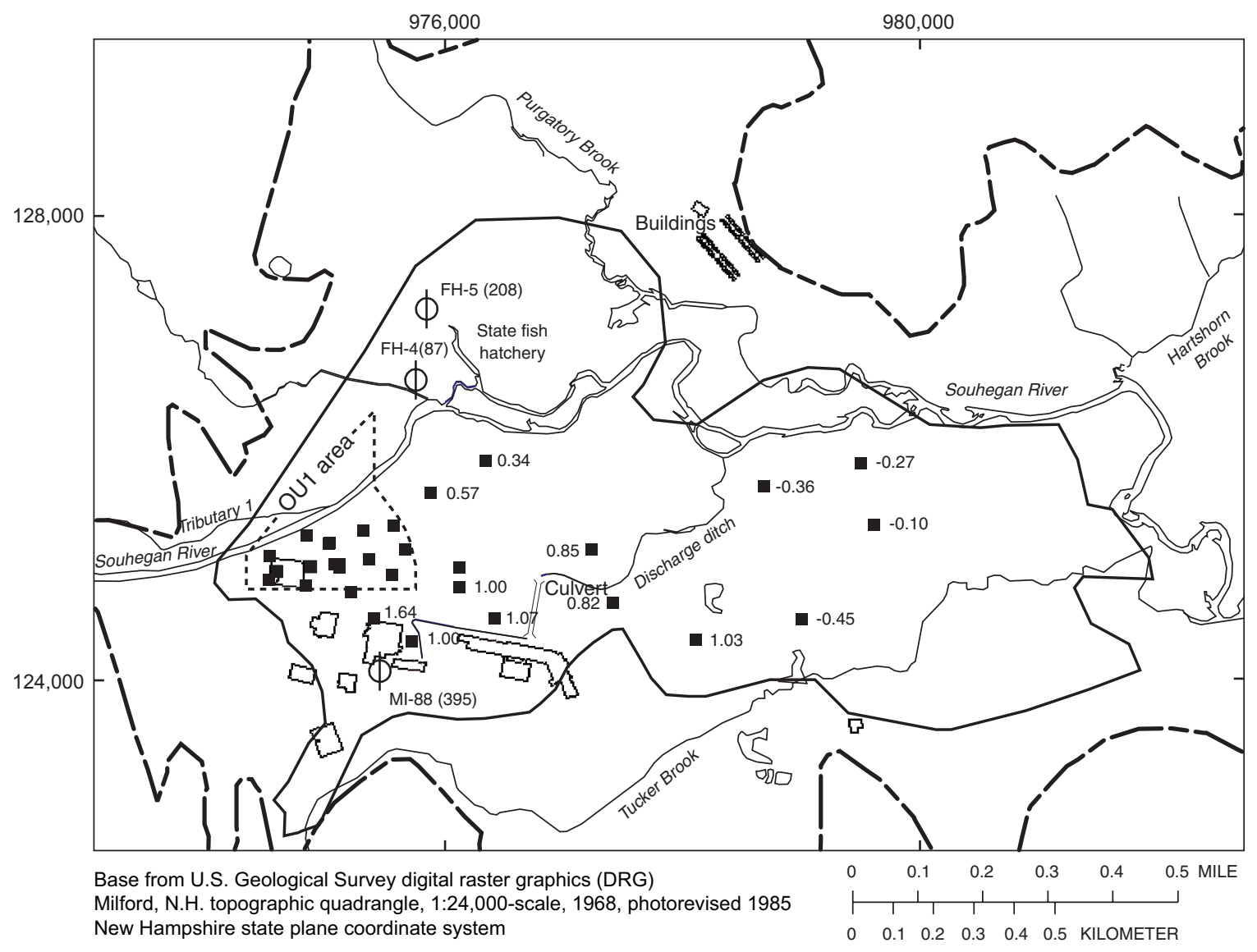

EXPLANATION

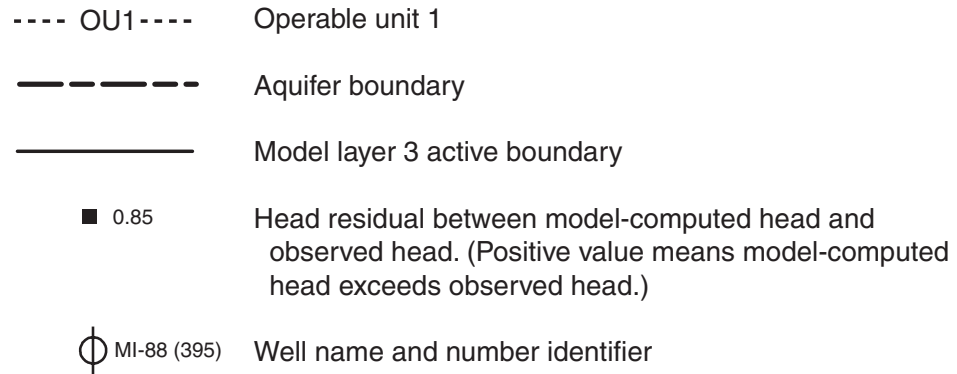

Figure 12. Head residuals (differences) between model-computed heads from steady-state simulation of 1995-98 conditions and observed heads from December 1998 for model layer 3, Milford-Souhegan glacial-drift aquifer, Savage Municipal Well Superfund site, Milford, N.H. 


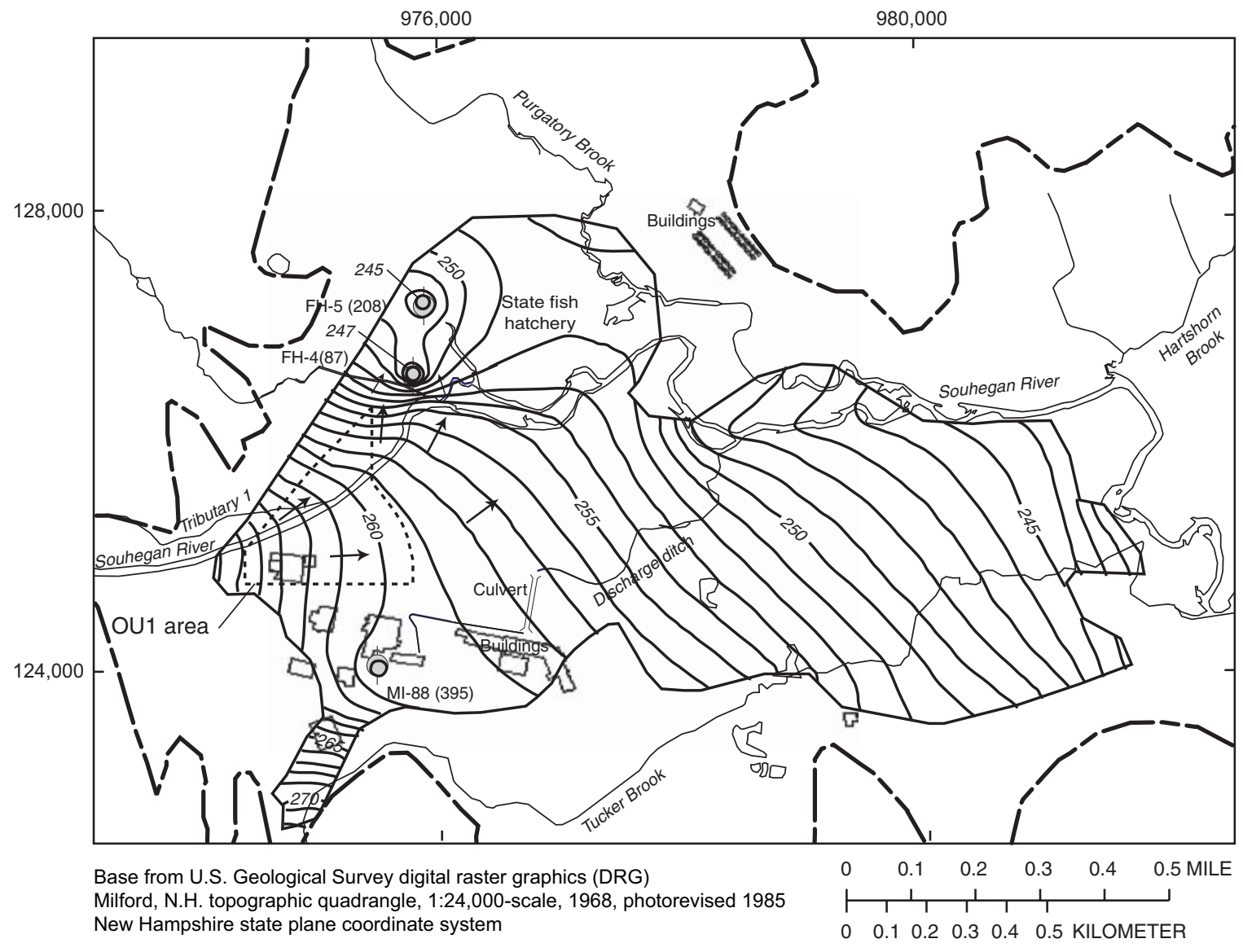

EXPLANATION

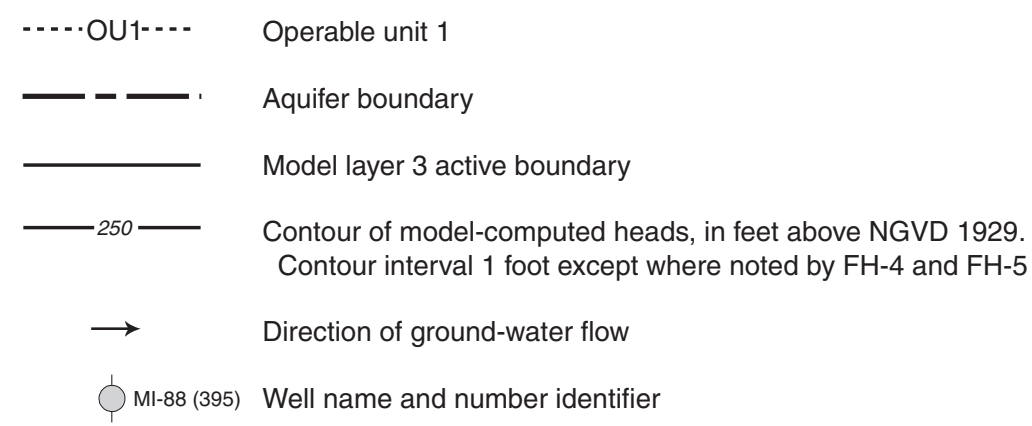

Figure 13. Contours of model-computed heads from steady-state simulation of 1995-98 conditions for model layer 3 , Milford-Souhegan glacial-drift aquifer, Savage Municipal Well Superfund site, Milford, N.H. 
at rates of generally $1 \mathrm{~L} / \mathrm{min}$ to prevent drawdown in the sampled wells. Water-quality field parameters (specific conductance, $\mathrm{pH}$, dissolved oxygen, and water temperature) were monitored for stability to help ensure a static source of water to the well. A minimum of one wellbore volume of water was evacuated prior to collecting environmental-isotope samples. Samples for tritium/helium were collected in a copper tube isolated from the atmosphere. Tritium/helium concentrations and apparent ages were analyzed according to methods described by Schlosser and others (1988).

The apparent ages of ground water that are derived from the tritium/helium concentration; the decay half-life of tritium; and the accuracy of measurement, in years, since the sampled water recharged the ground-water system are provided in table 6 . Ages ranged from 1 to 6 years. The oldest dated waters were from MW-16C and the youngest from B95-6. The accuracy of dated waters is approximately a third of a year. Concentrations of ${ }^{3} \mathrm{H}$ ranged from 8.5 (B95-8) to 10.1 (MW-16C) tritium units (TU). Concentrations of ${ }^{3} \mathrm{He}$ ranged from 0.51 (B95-6) to 3.96 (MW-16C) TU. Concentrations of helium-4 $\left({ }^{4} \mathrm{He}\right)$, which is derived from sources other than radiogenic decay of ${ }^{3} \mathrm{H}$, ranged from $5.28 \times 10^{-8} \mathrm{ccSTPg}^{-1}$ (B95-6) to $8.65 \times 10^{-8} \mathrm{ccSTPg}^{-1}$ (B95-3). Helium-4 is composed partly of terrigenic helium that is derived from degassing of the mantle (bedrock). The percent of terrigenic helium is high (35.2) at B95-3 and (18.9) B95-8 (table 6) and is probably caused by the water samples from these wells being taken near the bedrock surface and by the absence of a thick (10 ft or greater) till layer that would restrict gas movement from the bedrock.

Information on well screen, sample intake position of the bladder pump, sample-intake layer, and the corresponding model layer(s) of the well screen (well-screen layer) are listed in table 6. Most screens span more than one model layer (except B95-8), whereas the sample intake is a discrete point within a model layer. This information is important to understand potential sources of water, flow rates, and ages.

\section{Comparison with Model-Computed Ground-Water Ages}

Model-computed advective transport and time-of-travel were compared to apparent ground-water ages estimated by environmental isotopes. Computed ages were determined by backward tracking particles from the model cell where the well is located to their initial entry into the saturated ground-waterflow system; typically this represents the water-table surface or river cell. Particles were tracked with MODPATH (Pollock, 1994), which uses an advective-transport algorithm and ground-water flow computed from MODFLOW. Dispersion facilitates mixing of waters and increases the variation in tracked ages but is not included in the transport algorithm and model computation of age. Sixty-four particles were tracked from one cell (the cell containing the well). The number of cells (or layers) tracked depended on the well-screen length.

Model simulations were of steady-state conditions typical of the 1995-98 period. Hydrologic conditions in the OU1 area are assumed to be fairly constant from 1997 (when samples were collected) back to 1988 . All apparent ages generally fall into this time span. The ranges of apparent ages, generally greater than 1 year and less than 9 years, indicate that a steadystate model simulation can adequately approximate flow conditions because (1) the long-term variations (those affected by climatic and ground-water recharge changes and(or) major withdrawal changes in the aquifer) would be negligible for the OU1 area during this 1- to 9-year time span, and (2) short-term transients (those affected by seasonal variations) would be small for periods greater than 1 year.

Two sets of model-computed ages are provided in appendix 4. Mean ground-water ages are calculated from the computation of particles placed in (1) specific model layers that corresponded to the sample-intake layer, and (2) from model layers that corresponded to the entire screen interval. Particles tracked from the screen interval typically cover two model layers; therefore, the reported computed age is the mean age of 128 particles (64 per layer). In contrast, particles tracked from the sample intake cover only one model layer and the reported computed age is the mean age of 64 particles. The two sets of mean ages are used to evaluate the potential effect of vertical flow in the well during sampling. Vertical flow during sampling would induce waters to be derived from potentially the entire screen length rather than a specific intake depth.

The mean model-computed age from the discrete sample intake layer is older than the mean age from the screen layer(s) at wells B95-3 and B95-6, is the same age for well B95-8 (because the well is screened in only one layer), and is younger for wells MW-16B and MW-16C (appendix 4). The relation of mean ages computed for the sample intake layer and that of the screen layer is based on the differences in assigned horizontal hydraulic conductivity per model layer. For example, the horizontal hydraulic conductivity of the sample intake layer is less than the total screen layer(s) horizontal hydraulic conductivity at wells B95-3 and B95-6. Therefore, the computed mean age of the sample intake layer is older than the computed mean age of the entire screen layer because the screen layer incorporates a layer above that has a high horizontal hydraulic conductivity. Conversely, at wells MW-16B and MW-16C, the horizontal hydraulic conductivity of the entire screen layer(s) is less than the horizontal hydraulic conductivity of the sample intake layer and, as a result, the computed mean age for the sample intake layer is younger than the computed mean age for the entire screen layer.

An example of the vertical distribution of model-computed ages for individual particles, the mean particle age per layer, and the apparent ages is shown in figure 14 for two wells: B95-3 and B95-6. The vertical profile of individual particle ages is curvilinear at well B95-3 but shows an abrupt increase at well B95-6 (fig. 14). This abrupt increase corresponds to a large decrease (more than one-order of magnitude) in horizontal hydraulic conductivity from layer 2 to 3 . At well B95-3, the difference in horizontal hydraulic conductivity from layers 3 to 4 is less than a multiple of 3 , and, thus, the profile is fairly smooth. 
Table 6. Information on wells sampled in May 1997 for tritium-helium isotope and tritium-helium concentrations, Milford-Souhegan glacial-drift aquifer in the OU1 part of the Savage Municipal Well Superfund site, Milford, N.H.

[All wells installed in glacial-drift aquifer; Apparent age in years since water particle entered the ground-water system; ${ }^{3} \mathrm{H}$, tritium; TU, tritium units; ccSTPg ${ }^{-1}$, cubic centimeters per gram at standard temperature and pressure; ${ }^{3} \mathrm{He}$, Helium- $3 ;{ }^{4} \mathrm{He}$, Helium-4; >, greater than]

\begin{tabular}{|c|c|c|c|c|c|c|c|c|c|c|c|c|c|}
\hline \multicolumn{5}{|c|}{ Well information } & \multicolumn{2}{|c|}{ Model layers } & \multicolumn{7}{|c|}{ Isotope information } \\
\hline Well & $\begin{array}{l}\text { Top of well } \\
\text { screen } \\
\text { below land } \\
\text { surface, } \\
\text { in feet }\end{array}$ & $\begin{array}{l}\text { Bottom of } \\
\text { well screen } \\
\text { below land } \\
\text { surface, } \\
\text { in feet }\end{array}$ & $\begin{array}{l}\text { Depth to } \\
\text { bedrock } \\
\text { below land } \\
\text { surface, } \\
\text { in feet }\end{array}$ & $\begin{array}{l}\text { Depth to till } \\
\text { below land } \\
\text { surface, } \\
\text { in feet }\end{array}$ & $\begin{array}{l}\text { Layer of } \\
\text { sample } \\
\text { intake }\end{array}$ & $\begin{array}{l}\text { Layers of } \\
\text { screen } \\
\text { interval }\end{array}$ & $\begin{array}{l}\text { Apparent age, } \\
\text { in years from } \\
\text { titium/helium } \\
\text { analysis } \\
\text { (May 1997) }\end{array}$ & $\begin{array}{c}\text { Accuracy, } \\
\text { in years of } \\
\text { tritium/ } \\
\text { helium }\end{array}$ & $\begin{array}{l}\text { Tritium } \\
{\left[{ }^{3} \mathrm{H}\right], \mathrm{TU}}\end{array}$ & $\begin{array}{c}\text { Accuracy of } \\
\text { tritium, } 1 \\
\text { standard } \\
\text { deviation TU }\end{array}$ & ${ }^{3} \mathrm{He}, \mathrm{TU}$ & $\begin{array}{l}{ }^{4} \mathrm{He} \text {, in } \\
\text { ccSTPg-1 }\end{array}$ & $\begin{array}{c}\text { Terrigenic } \\
{ }^{4} \mathrm{He} \text {, in } \\
\text { percent }\end{array}$ \\
\hline B95-3 & 61.5 & 71.5 & 86.0 & Not detected & 4 & $3-4$ & 2.69 & 0.33 & 9.48 & 0.19 & 1.53 & $8.65 \mathrm{E}-08$ & 35.20 \\
\hline B95-6 & 41.5 & 51.5 & $>62$ & 50.0 & 3 & $2-3$ & .92 & .33 & 9.70 & .19 & .51 & $5.28 \mathrm{E}-08$ & .00 \\
\hline B95-8 & 72.0 & 82.0 & 88.0 & 85.0 & 4 & 4 & 4.90 & .34 & 8.50 & .19 & 2.68 & $6.97 \mathrm{E}-08$ & 18.90 \\
\hline MW-16B & 39.6 & 49.6 & 87.5 & 84.0 & 2 & $2-3$ & 2.37 & .30 & 9.40 & .20 & 1.32 & $6.23 \mathrm{E}-08$ & .60 \\
\hline MW-16C & 73.2 & 83.2 & 87.5 & 84.0 & 4 & $4-5$ & 5.94 & .30 & 10.10 & .20 & 3.96 & $5.96 \mathrm{E}-08$ & 10.90 \\
\hline
\end{tabular}


A.

B95-6

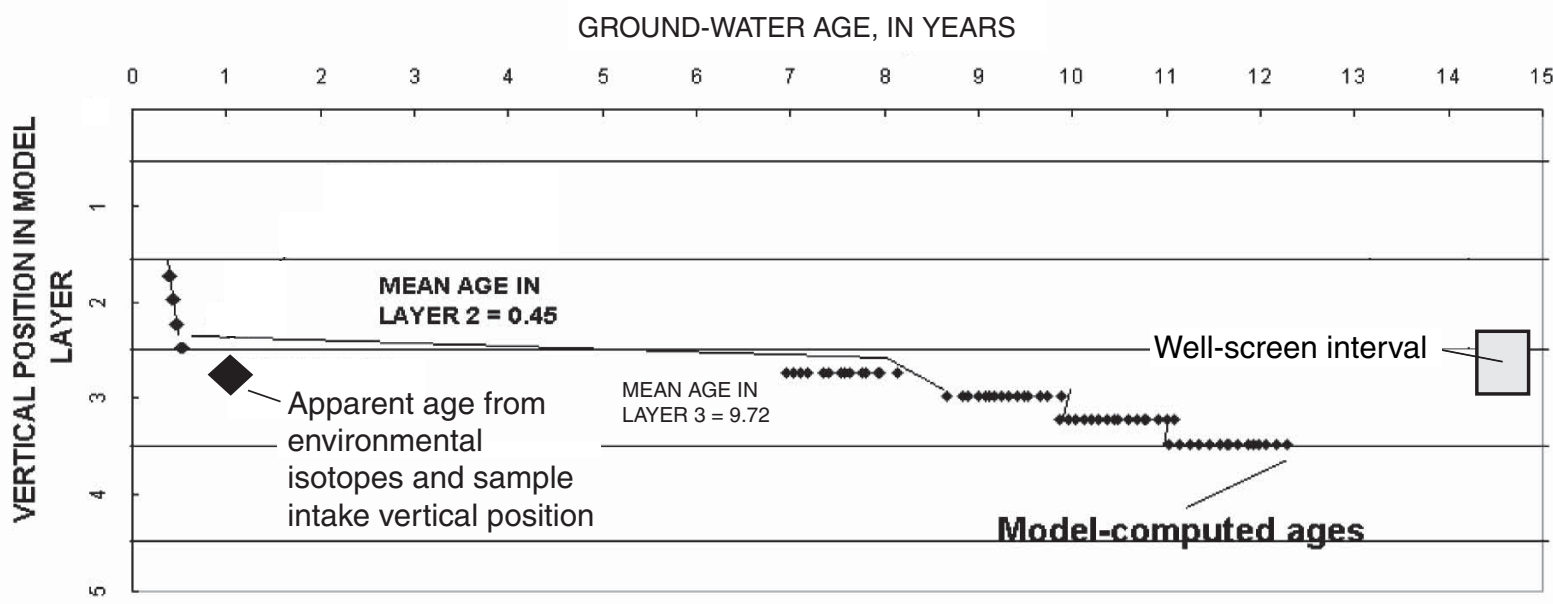

B. B95-3

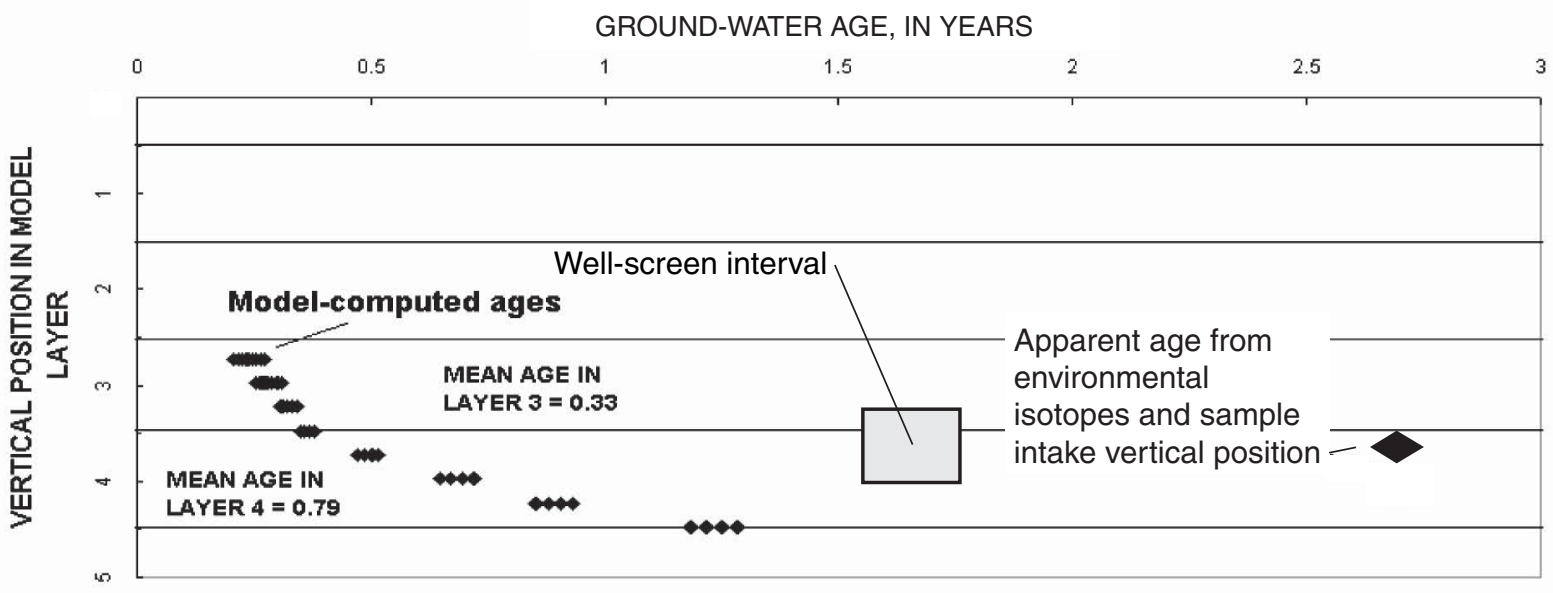

Figure 14. Comparison of model-computed ages in relation to apparent ages for (A) wells B95-6 and (B) B95-3 showing discrete ages of individual particles and mean age per model layer from simulation of 1995-98 steady-state conditions and apparent age from tritium-helium concentrations in May 1997 samples, Milford-Souhegan glacial-drift aquifer, in the OU1 part of the Savage Municipal Well Superfund site, Milford, N.H.

A statistical summary of model-computed ages from six model simulations is included in appendix 4 . The statistical summary includes the mean value of the tracked particle ages and the minimum and maximum ages. The simulations were used to analyze the effects of alternative horizontal hydraulic conductivities in layers 2 and 5 and vertical anisotropy in selected model layers (a summary of assigned model input is given in appendix 3). Porosity also was varied in layers 2 and 4 for one simulation (appendix 4). Computed mean ages are older for simulations with the porosity set at 0.35 for layers 2 and 4 because the porosity term in the advective-transport tracking algorithm is used in the denominator to calculate a groundwater velocity.

At wells B95-6, B95-8, and MW-16C, the difference between minimum and maximum ground-water ages of discrete particles is large and the range brackets the apparent age of samples from these wells (appendix 4). Thus, modifications to model input were not needed to improve calibration for hydraulic characteristics affecting these wells. Model-input modifications were necessary to help match computed ages with apparent ages for wells MW-16B and B95-3, where discrete particle ages did not bracket apparent ages. 
The pre-remedial calibration analysis of particle ages indicates that a decrease of horizontal hydraulic conductivity from $200 \mathrm{ft} / \mathrm{d}$ to $86 \mathrm{ft} / \mathrm{d}$ in layer 2 improves the match between modelcomputed and apparent ages. Age matching also is improved if vertical anisotropy is reduced in selected model layers. The final calibrated-model (run 125, appendixes 3 and 4) results show that computed mean ages from the screen interval and sample-intake layer bracket the apparent age at well MW-16C, are close to the apparent age at well MW-16B, are older at B95-6, and younger by about 25 percent at well B95-8, and 50 percent at well B95-3. At well B95-3, the difference between computed mean age and apparent age is large and attributed to a localized fine-grained layer that is not adequately approximated in the model. Although the computed mean ages (1.16 years for the screen interval and 1.66 years for the sample-intake layer) are less at B95-3 than the apparent age (2.69 years), some individual particle ages approach the apparent age.

\section{Solute Transport}

The solute transport of PCE was solved for the pre-remedial simulation with the ELLAM solver (Heberton and others, 2000), which allows for the use of a grid with nonuniform cell sizes in transport solutions. The use of this solver allowed the transport domain (subgrid) to be extended north to row 23 from row 53 (plate 4) and, therefore, include transport to the State Fish Hatchery wells. All five model layers are simulated.

Final values for the solute-transport parameters used for the pre-remedial simulation included a retardation of 2 in layers 1,3 , and 5 and 2.5 in layers 2 and 4. Longitudinal and transverse dispersivities were 54 and $12 \mathrm{ft}$, respectively. Vertical dispersivity was 0.1 of the transverse or $1.2 \mathrm{ft}$ or 0.02 of the longitudinal value of $54 \mathrm{ft}$. Gelhar and others (1992), in their study of field-scale dispersivities, show ranges of longitudinal dispersivity from 15 to $1,500 \mathrm{ft}$, horizontal transverse dispersivity from 3 to $150 \mathrm{ft}$, and vertical dispersivity from 0.001 to $1.0 \mathrm{ft}$ for a plume the size of that at the Savage site.

Degradation was not simulated in the pre-remedial calibration, unlike the historical calibration period, for three reasons. First, the historical calibration showed small degradation rates (half-life of about 20 years) that would have a minimal effect during the 1995-98 calibration. The pre-remedial model calibration would be relatively insensitive to this factor because less than 10 percent of the plume could be degraded in a 3.5 -year period ( 50 percent in a 20 -year period). Second, the 1995-98 field data show no accumulation of secondary daughter products in the OU2 area, and concentrations of TCE and cis-1,2-DCE are consistently about one-tenth that of PCE concentrations. Lastly, concentrations of compounds such as vinyl chloride, ethane, or ethene, which would indicate complete degradation of PCE in the plume, are generally below detection levels. Low levels indicate the degradation cycle in the Savage site plume is incomplete.

Volatilization across the water-table surface was simulated by assigning a small irreversible reaction rate (decay rate) of
$6.0 \mathrm{e}^{-13}$ to $6.0 \mathrm{e}^{-11}$, which is equivalent to a half-life ranging from 36,600 to 360 years. Rates of volatilization were not measured for this study but taken from findings from studies of a VOC plume at the USGS Toxic Waste Study Site at Picatinny Arsenal in New Jersey.

The initial starting mass of PCE from June 1995 was input into the solute-transport model (figs. 6 and 7). A detailed description of the plume and the interpolation process used to generate the initial PCE mass is discussed in the "Description and Trends of the Savage Site Volatile Organic Compound Plume" section of this report. The total sorbed and dissolved starting mass is estimated to be $4.57 \mathrm{Mg}$; the dissolved starting mass is $2.06 \mathrm{Mg}$. The total mass (sorbed and dissolved) is a function of the assigned values of retardation per model layer.

No growth of the PCE mass is assumed to occur during the simulated period. This assumption is not fully valid because some additional mass of PCE enters the dissolved phase from dissolution of the DNAPL that is present in the OU1 area. Because the model does not explicitly simulate this condition, some error is introduced into the simulation. Therefore, modelcomputed PCE concentrations are only compared to measured concentrations at the OU2 wells, which are all about 1,500 ft east of the contaminant source in OU1.

Results from the calibrated simulation (model run r125, appendix 3) show that model-computed PCE concentrations are comparable to the observed PCE concentrations in most areas of OU2. The summary statistics of computed PCE to observed PCE for OU2 wells (46 wells) for December 1998 indicate that the standard mean error is $27 \mathrm{ppb}$, the absolute mean error is $121 \mathrm{ppb}$, and the root-mean square error (RMSE) is $229 \mathrm{ppb}$. A plot of computed and observed PCE concentrations is shown in figure 15. Results beyond one standard deviation are labeled. Wells with a positive bias (computed concentrations exceed observed concentrations), ranked in descending difference, include MW-11B, MW-11A, MW-101B, MW-10B, MW-10A, MI-8, and MW-101A. Wells with a negative bias (computed concentrations are less than observed concentrations), ranked in descending difference, include MW-20B, MW-13A, and MW$101 \mathrm{C}$.

Wells MW-11A and B are on the northern flank of the plume (plate 1) and indicate a tendency of the model to overpredict concentrations in this area. Well MW-20B is in the southern part of the plume and a comparison of computed to observed PCE concentrations indicates a tendency of the model to underpredict concentrations at this location. The differences between computed and observed PCE at MW-10 and MW-101 clusters can be attributed to the model overmixing PCE vertically and underpredicting the vertical stratification of PCE. When integrated over the full thickness of the aquifer (from a 2-d horizontal perspective), the computed PCE concentrations at MW-10 and MW-101 clusters are comparable to observed concentrations.

The solute-transport budget for the pre-remedial simulation period shows that most of the PCE mass is being discharged to the river at a rate of $0.32 \mathrm{Mg} / \mathrm{yr}$, or 97 percent of the total loss of PCE mass. No active remedial wells were operating 


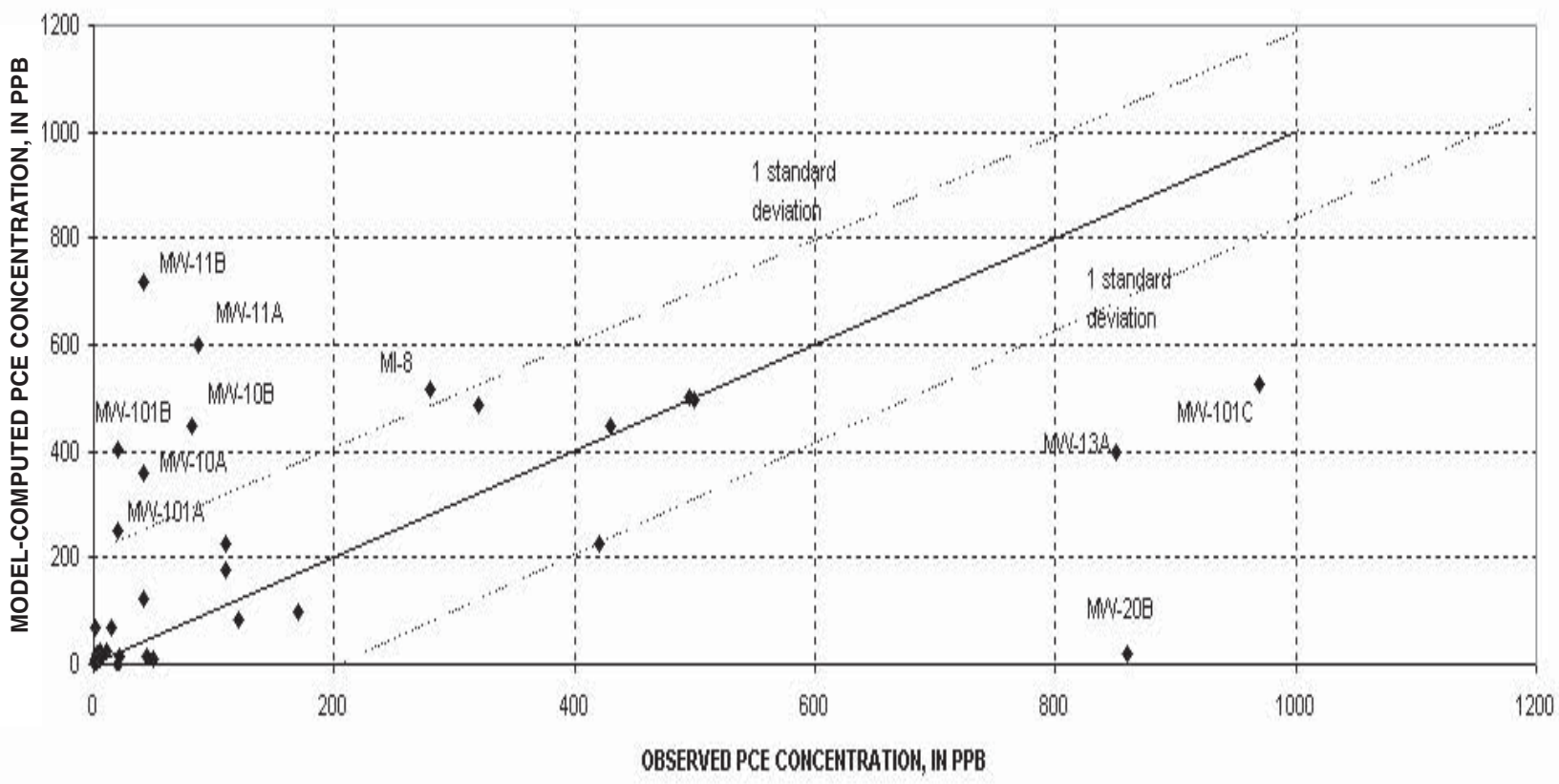

Figure 15. Comparison of model-computed and observed tetrachloroethylene (PCE) concentrations, December 1998, in the OU1 part of the Savage Municipal Well Superfund site, Milford, N.H. (Concentration in parts per billion [ppb]. Well locations shown on plate 1.)

during the pre-remedial period but some PCE mass

$(0.01 \mathrm{Mg} / \mathrm{yr})$ is captured by withdrawals at the State Fish Hatchery wells (FH-4 and FH-5, fig. 2). Maximum model-computed PCE concentrations at FH-4 were 7 ppb and at FH-5 were $14 \mathrm{ppb}$. Observed concentrations of PCE were $3 \mathrm{ppb}$ at FH-4 and non-detectable (less than $2 \mathrm{ppb}$ ) at FH-5. Thus, the model slightly overpredicts PCE transport to the FH-5 well, and underpredicts to the FH-4 well. Loss of PCE mass from irreversible reactions (to simulate volatilization) is small $(0.00075 \mathrm{Mg} / \mathrm{yr})$. Negligible amounts of PCE mass are being transported beyond the subgrid boundary because the subgrid boundary was extended north to row 23 (two rows north of FH-5 well) from row 53 (plate 4 ) for the pre-remedial simulations.

The model-computed PCE mass decrease (sorbed and dissolved) is about $0.32 \mathrm{Mg} / \mathrm{yr}$ for the pre-remedial simulation. An independent calculation of PCE-mass decrease from 1995 to 1998 , on the basis of trends in observed PCE concentrations, indicates that about $0.25 \mathrm{Mg}$ of PCE is lost per year. These estimates are comparable, considering that the observed data could be affected by some mass input of PCE from dissolution of DNAPLs, which would decrease the rate of decline in observed PCE mass.

\section{Remedial Simulation}

The remedial calibration was examined with the 3-d flow model that was used in the pre-remedial calibration, with modifications as discussed in the following paragraphs. Aquiferstorage properties were incorporated into the remedial model to simulate transient ground-water-flow conditions resulting from variable rates of recharge, storage, and withdrawals that occurred during the remedial calibration period. The model for the remedial calibration also includes hydraulic and solutetransport parameters that approximate features caused by the incorporation of the barrier wall and the remedial extraction and injection wells.

The remedial calibration period was from December 1998, which coincides with the completion of the barrier wall in OU1, to October 1999. This period was characterized by large decreases in PCE concentrations outside of the barrier wall in OU1 as a result of source containment (Harte and others, 2001). Hydrologic conditions from December 1998 to September 1999 were marked by slightly below average ground-water levels (Brayton and Harte, 2001). In September 1999, a large storm producing over $9 \mathrm{in}$. of rain caused large increases in water levels (Brayton and Harte, 2001). 
Withdrawals were fairly constant for the nonremedial wells during this remediation period and were approximately $4.58 \mathrm{ft}^{3} / \mathrm{s}$, about $0.4 \mathrm{ft}^{3} / \mathrm{s}$ greater than the pre-remedial rates as a result of increases in 1999 at the State Fish Hatchery well FH-4 closest to the river (fig. 2, plate 1). Withdrawals began sporadically for remedial wells (both extraction and injection) in OU1 during April 1999, but remained fairly constant from May 1999 to October 1999. Information on rates of remedial operation, as reported in May 1999, is given in table 7. A net extraction of $9.6 \mathrm{gal} / \mathrm{min}$ of water from inside the barrier was discharged outside the barrier through the recharge gallery (table 7, fig. 3).

The estimated average recharge rate from infiltration of precipitation inside the barrier is $1.75 \mathrm{gal} / \mathrm{min}$ (Brayton and Harte, 2001). Brayton and Harte (2001) showed that recharge rates inside the barrier area decreased by as much a half from pre-construction periods because of the addition of a semiconical, land-surface cap during barrier-wall construction.

The ground-water budget for inside the barrier wall is summarized as follows:

Net extraction $=$ direct recharge + bedrock upflow + net storage change + inflow/outflow net flux through the barrier wall,
$9.6 \mathrm{gal} / \mathrm{min}=1.75 \mathrm{gal} / \mathrm{min}+7.4 \mathrm{gal} / \mathrm{min}+$ net storage change +

netinflow/outflow through the barrier wall,

and

$0.45 \mathrm{gal} / \mathrm{min}=$ net storage change + netinflow/outflow through the barrier wall.

The transient remedial model solves for the right-hand side of equation 9. The residual ground-water budget during periods of net extraction inside the barrier (the $9.6 \mathrm{gal} / \mathrm{min}$ net extraction rate minus the estimated recharge rate of $1.75 \mathrm{gal} / \mathrm{min}$ ) is $7.85 \mathrm{gal} / \mathrm{min}$ and consists of upflow from the bedrock, a net change in aquifer storage, and net inflow/outflow of groundwater flow through or under (between the bottom of the barrier and the underlying bedrock) the barrier wall. The principal source of ground water inside the barrier wall during remedial operations is probably upflow of ground water from the bedrock.

Upflow from the bedrock is qualitatively identifiable as measured from vertical-head gradients at cluster wells inside the wall (data on file at the New Hampshire-Vermont District office, Pembroke, N.H.). The direction of vertical-head gradi-

Table 7. Rates of extraction and injection for remedial wells in OU1 as reported in May 1999, Savage Municipal Well Superfund site, Milford, N.H.

[No., number; gal/min, gallons per minute; $\mathrm{ft}^{3} / \mathrm{s}$, cubic feet per second; to convert gal $/ \mathrm{min}$ to $\mathrm{ft}^{3} / \mathrm{s}$, multiply by $0.00223 ;--$, no data]

\begin{tabular}{|c|c|c|c|c|c|}
\hline Well name & $\begin{array}{l}\text { Well No. used } \\
\text { in this report } \\
\text { (plate 2) }\end{array}$ & $\begin{array}{l}\text { Location with } \\
\text { respect to } \\
\text { barrier wall in } \\
\text { OU1 }\end{array}$ & $\begin{array}{l}\text { Rate of extraction } \\
\text { or injection, } \\
\text { in gal/min } \\
\text { (negative indicates } \\
\text { injection) }\end{array}$ & $\begin{array}{l}\text { Rate of } \\
\text { extraction or } \\
\text { injection, } \\
\text { in } \mathrm{ft}^{3} / \mathrm{s}\end{array}$ & Comments \\
\hline IW-1 & 567 & Inside & 10.0 & 0.02 & \\
\hline IW-2 & 568 & Inside & 9.0 & .02 & \\
\hline RW-1 & 569 & Inside & -4.7 & -.01 & \\
\hline RW-2 & 570 & Inside & -4.68 & -.01 & \\
\hline SVE-1-6 & $574-579$ & Inside & 0 & 0 & $\begin{array}{l}\text { Soil vapor extraction wells No. } 1-6 \text {; } \\
\text { not simulated in model. }\end{array}$ \\
\hline SP-1-2 & $572-573$ & Inside & 0 & 0 & $\begin{array}{l}\text { Sparging wells No. } 1-2 ; \text { not simulated } \\
\text { in model. }\end{array}$ \\
\hline EW-1 & 565 & Outside & 25.0 & .056 & \\
\hline EW-2 & 566 & Outside & 24.8 & .055 & \\
\hline Recharge gallery & -- & Outside & -59.4 & -.13 & \\
\hline RW-3 & 571 & Outside & 0 & 0 & \\
\hline
\end{tabular}


Before extraction, primarily downward vertical-head gradients are present from the overburden to bedrock. During extraction, upward vertical-head gradients are present from the bedrock to the overburden on the downgradient side of the inside wall area. Water levels in bedrock inside the barrier decreased during net extraction, indicating a hydraulic connection between the overburden and bedrock. To simulate upflow from the bedrock, a series of injection wells were added to the model at the base of the overburden because the bedrock is not simulated in the model. A total rate of $7.4 \mathrm{gal} / \mathrm{min}$ was used based on calculations of ground-water flow budget. The relatively large amount of bedrock upflow inside the barrier has consequences for remediation by reducing the operating time of the SVE wells, and consequently, the mass of PCE removed.

Overburden storage changes are assumed to contribute less to the net water extracted inside the barrier than upflow from the bedrock. From the last week of May to the last week of June in 1999, precipitation was less than 0.2 in., resulting in negligible recharge to the overburden inside the barrier, yet ground-water levels at well B95-9 (inside the barrier) decreased by only $0.8 \mathrm{ft}$. The total contribution from storage for this period is estimated to be less than $1.2 \mathrm{gal} / \mathrm{min}$. The change in storage was computed by multiplying the area inside the wall $\left(2,230,272 \mathrm{ft}^{2}\right)$ by the effective ground-water level decrease of $0.8 \mathrm{ft}$ (measured at well B95-9), and using an estimated specific yield of 0.23 (Harte and others, 1999).

The amount of inflow and outflow either through or under the barrier is also considered a small part of the water budget for the interior wall area. An analysis of ground-water levels preand post-barrier construction shows that ground-water levels inside the barrier are poorly correlated with water levels outside the barrier; suggesting large amounts of inflow/outflow through or under the barrier are unlikely.

The remedial simulation is subdivided into seven stress periods of different lengths of time that correspond to periods with unique stresses. Within each stress period, rates of recharge and withdrawals are constant. Rates of recharge, however, varied between the modeled stress periods to approximate ground-water-flow conditions for the remedial calibration period. The relative percent difference in recharge rates were spatially maintained and rates inside the barrier were 50 percent of rates outside the barrier. Recharge rates were varied based on seasonal trends in recharge efficiency or the percentage of direct precipitation that recharges the aquifer as discussed in Harte and others (1999). Recharge efficiency is high (as much as 90 percent of precipitation recharges the aquifer) during periods of negligible evapotranspiration. Recharge efficiency is low (as little as 25 percent of precipitation recharges the aquifer) during periods of high evapotranspiration in the summer. The average steady-state recharge rate used in the historical and preremedial models was about $26.2 \mathrm{in} / \mathrm{yr}$ or $2.18 \mathrm{in} / \mathrm{mo}$. The monthly recharge rates assigned to the remedial model from December 1998 to August 1999 ranged from a low of $0.63 \mathrm{in} / \mathrm{mo}$ in July 1999 to a high of $2.18 \mathrm{in} / \mathrm{mo}$ in April 1999. In September 1999, $6.9 \mathrm{in} / \mathrm{mo}$ of recharge was assigned because of a large amount of precipitation (over 9 in.).
The MODFLOW Horizontal-Flow Barrier Package (HFB) (Hsieh and Freckleton, 1993) is used to simulate the barrier for the remedial simulation. The wall was set at a hydraulic conductivity value of $5.0 \mathrm{e}^{-08} \mathrm{~cm} / \mathrm{s}$ or $1.64 \mathrm{e}^{-09} \mathrm{ft} / \mathrm{s}$ based on reported permeability tests of the barrier slurry (Peter J. Borowiec, Camp, Dresser, and McKee, Inc., written commun., 1998). The barrier-wall thickness is $3 \mathrm{ft}$ and extends from above the water table to the bedrock or till surface. The ARGUS MODFLOW GUI (Winston, 2000) was used to assign barrier-wall hydraulic properties to model cells for the remedial simulations.

Starting conditions utilized a steady-state head solution for May 1999. May 1999 heads are an adequate approximation of average annual heads for water year 1999. A steady-state solution of heads from December 1998 was not used for initial conditions because the wall was just installed and extraction wells were not operating inside the barrier. A steady-state solution under these conditions would produce artificially high heads inside the wall. Instead, a steady-state solution for May 1999 conditions, including operation of interior-wall extraction wells, was used for initial heads.

\section{Ground-Water Flow}

The evaluation and calibration of ground-water flow for the remedial period included the comparison of transient model-computed heads to observed heads over time. Data sets used for the comparison included manual water-level measurements from May 1999, August 1999, and September 1999; and continuous measurements from selected continuously monitored water-level wells.

Head residuals are generally small (standard mean error of less than $1 \mathrm{ft}$ ) between the model-computed and observed heads for May 1999, but residuals are greater in some areas. Summary statistics of head residuals from 115 observation wells in OU1 and OU2 indicate computed heads are, on average, slightly greater than observed heads (the standard mean error is $0.36 \mathrm{ft}$ and the absolute mean error is $0.92 \mathrm{ft}$ ). The pattern of head residuals in the OU2 area for the remedial simulation is similar to that shown in figure 11 for the pre-remedial simulation. Head residuals are less for OU2 wells than for OU1 wells, with a standard mean error of $0.03 \mathrm{ft}$ and $0.68 \mathrm{ft}$, respectively, and an absolute mean error of $0.88 \mathrm{ft}$ and $0.98 \mathrm{ft}$, respectively. Head residuals are greatest for the area inside the interior barrier within OU1 (a standard mean error of $2.33 \mathrm{ft}$ and an absolute mean error of $2.33 \mathrm{ft}$ ) and indicate a slow response to simulated extraction at wells IW1 and IW2 that started in May 1999. However, comparison of computed and observed heads for well B95-9 (located inside the barrier) shows that head residuals decrease from a high of $2.42 \mathrm{ft}$ in May 1999 to less than $0.20 \mathrm{ft}$ in August 1999.

Trends in model-computed heads compare favorably to trends in observed heads. An example is provided in figure 16 for observation well PW-1D, which is about $20 \mathrm{ft}$ from well EW1 (fig. 3). The decrease in computed and observed heads is about $0.5 \mathrm{ft}$ from early May 1999 to late June 1999 because of extraction at EW1 (extraction rate of $25 \mathrm{gal} / \mathrm{min}$ ) and EW2 


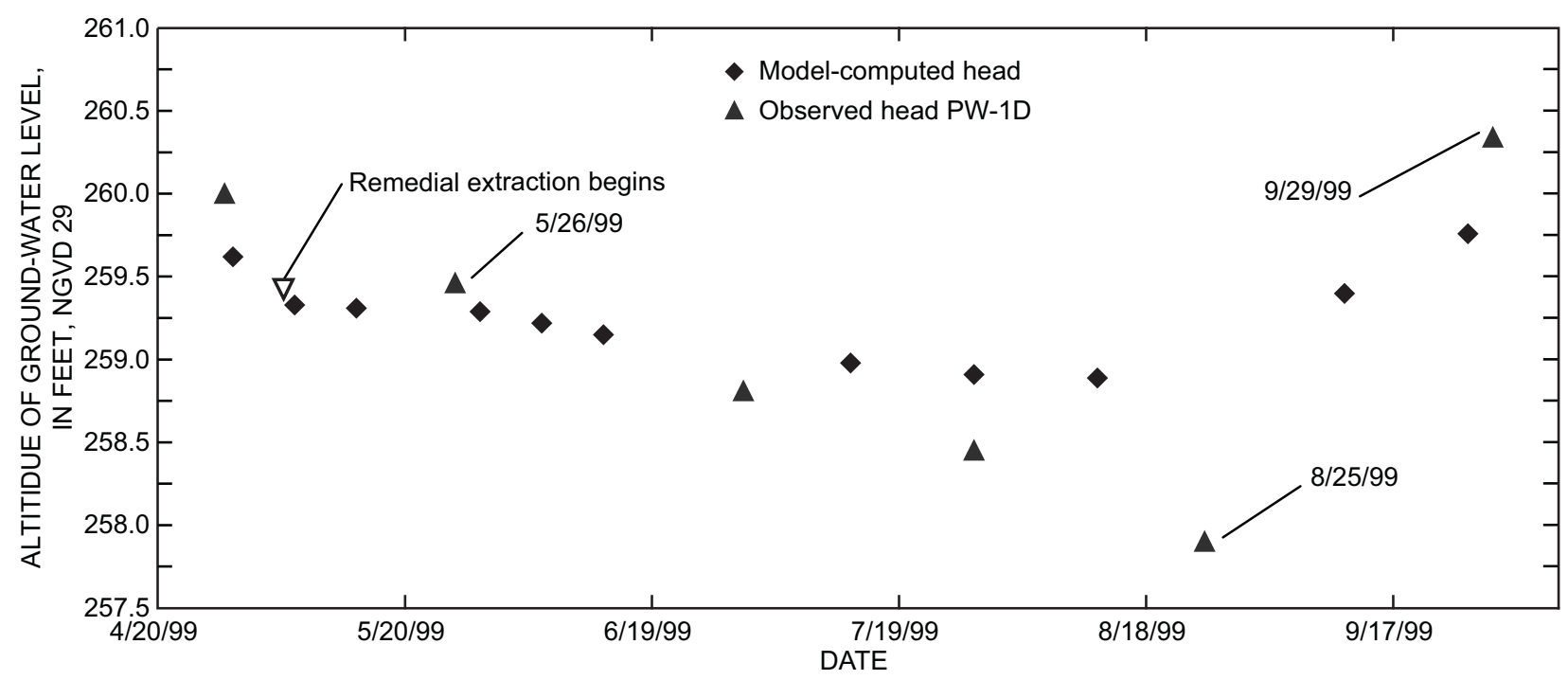

Figure 16. Model-computed and observed heads from April to September 1999 for well PW-1D, Milford-Souhegan glacial-drift aquifer, in the OU1 part of the Savage Municipal Well Superfund site, Milford, N.H.

(similar rate of extraction). Computed heads exceed observed heads by about $1 \mathrm{ft}$ in late August 1999 (fig. 16). A likely reason why computed head decreases were underpredicted in late August 1999 is that the simulation may overestimate recharge from river leakage. This overestimation is because river-stage values were not adjusted during the remedial simulation period and model river-stage values were assigned average stage values. Conversely, computed head rises are less than observed head rises in late September of 1999 after 9 in. of precipitation fell and river stage increased.

A map of model-computed heads for August 1999 shows the tendency of the model to overpredict heads by about $1 \mathrm{ft}$ (see point values in figure 17). However, computed flow patterns correctly reproduce observed flow patterns and show an inward gradient (from outside the barrier to inside the barrier) on the downgradient side of the barrier. On the outside, upgradient side of the barrier, the steep head gradients (caused by the river) tend to insure inward gradients into the barrier for both the computed and observed heads. On the outside, downgradient side of the barrier, the extraction of ground water at wells EW1 and EW2 causes slight curvature of heads toward these wells (see model contours in figure 17). Inside the barrier, extraction at wells IW1 and IW2 causes a uniform decrease of heads and the barrier appears to be effectively encapsulating the flow system as indicated by the flat hydraulic gradient inside the barrier and the absence of circular cones of depression for the two interior extraction wells (IW1 and IW2, fig. 17).

A map of model-computed heads for September 1999

(fig. 18) compares favorably to observed head values (see point values in fig. 18) except for the inside of the barrier where computed heads are lower than observed heads. As a result, computed flow patterns incorrectly reproduce observed flow patterns and the model shows an inward gradient on the downgradient side of the barrier. Possible reasons for the model underpredicting rises in interior heads is that the numerical time discretization is too coarse to adequately simulate the high recharge in this month, or that the simulation underestimates recharge inside the barrier during the September high-recharge event (model-assigned recharge rates were spatially varied; rates inside the barrier were half of the rates outside the barrier).

The computed ground-water-flow budget for August and September 1999 shows that over this time frame large variations in rates of storage, river leakage, and recharge can occur in the aquifer and that these rates can vary appreciably from steady-state rates. The flow budget for the 2 months is shown in figure 19. During August 1999, a low recharge period $\left(1.37 \mathrm{ft}^{3} / \mathrm{s}\right)$, the simulated source of ground water is derived primarily from river seepage $\left(5.25 \mathrm{ft}^{3} / \mathrm{s}\right)$ and small amounts from storage $\left(0.28 \mathrm{ft}^{3} / \mathrm{s}\right)$. Ground-water discharge to the river is relatively low $\left(2.85 \mathrm{ft}^{3} / \mathrm{s}\right)$, yielding a net loss of river seepage of $2.4 \mathrm{ft}^{3} / \mathrm{s}$. During September 1999, a high recharge period $\left(10.09 \mathrm{ft}^{3} / \mathrm{s}\right)$, river seepage into the aquifer decreases to $3.87 \mathrm{ft}^{3} / \mathrm{s}$ and large amounts of ground water goes into storage $\left(5.28 \mathrm{ft}^{3} / \mathrm{s}\right)$. Ground-water discharge to the river increases to $4.40 \mathrm{ft}^{3} / \mathrm{s}$, yielding a net gain of river seepage of $0.53 \mathrm{ft}^{3} / \mathrm{s}$ for September. In contrast, the computed ground-water-flow budget for the steady-state pre-remedial simulation shows a net river seepage loss of $0.32 \mathrm{ft}^{3} / \mathrm{s}$. 


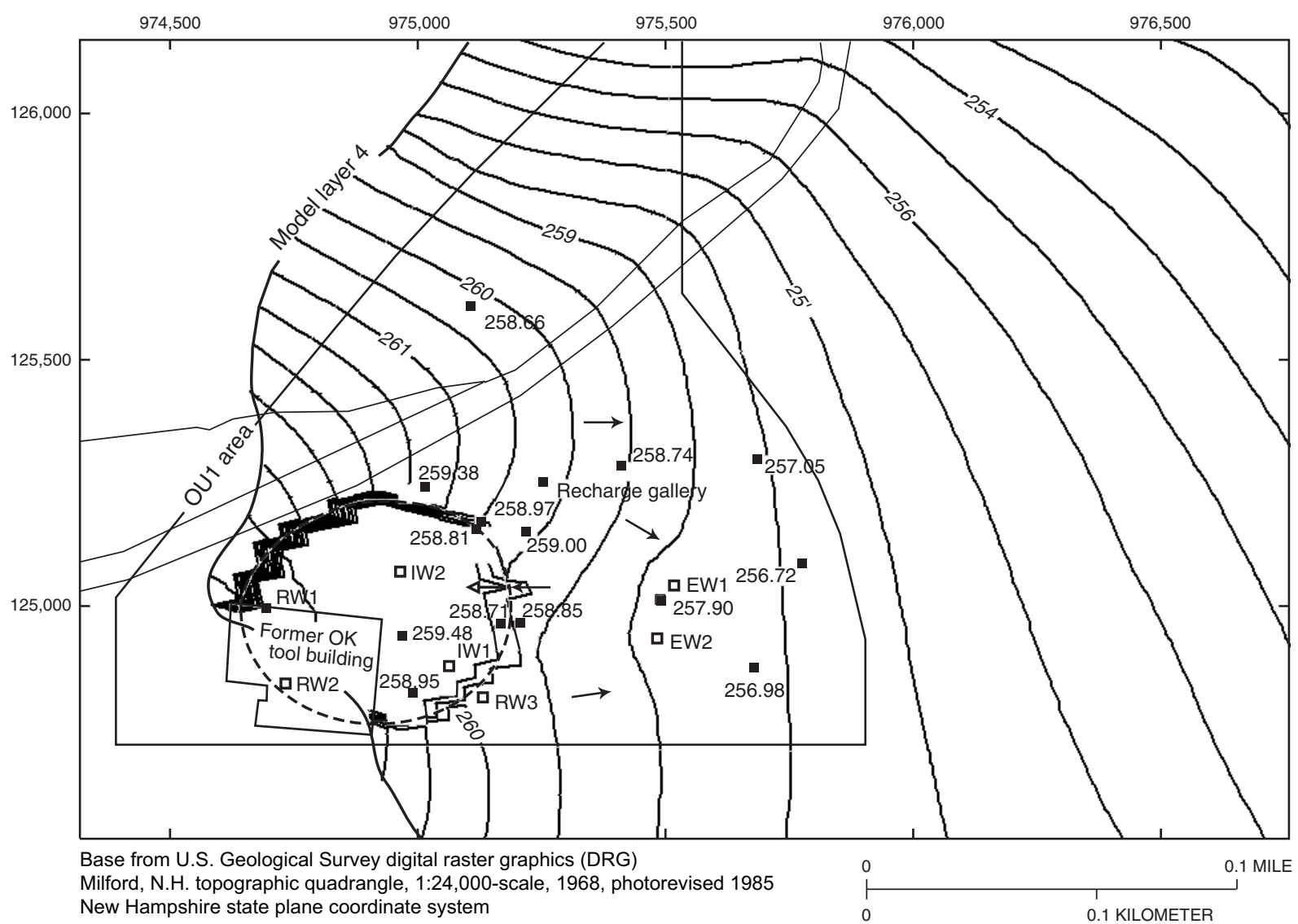

EXPLANATION

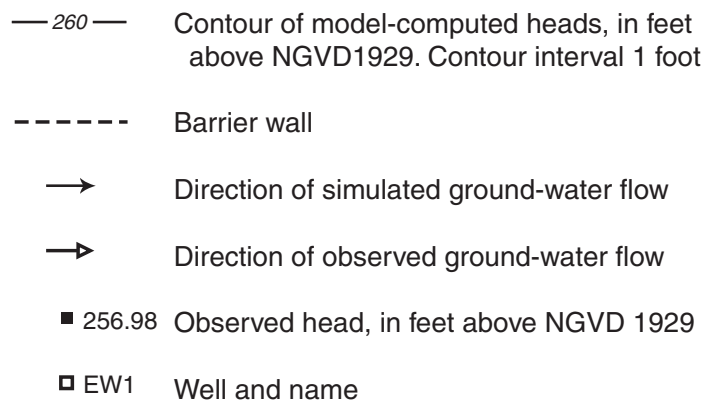

Figure 17. Contours of model-computed heads from remedial simulation and observed heads, August 1999, for model layer 4, Milford-Souhegan glacial-drift aquifer, in the OU1 part of the Savage Municipal Well Superfund site, Milford, N.H. 


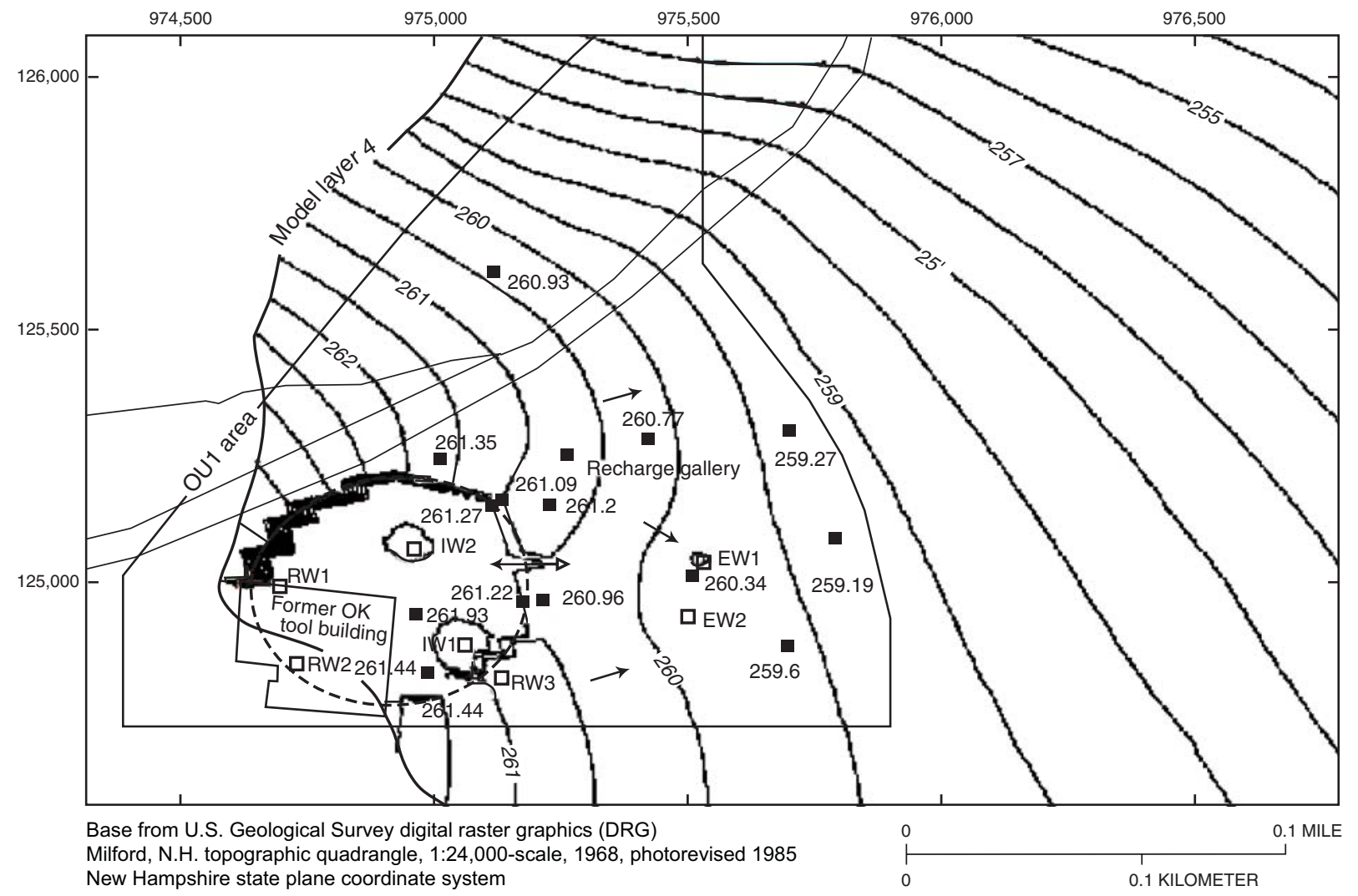

EXPLANATION

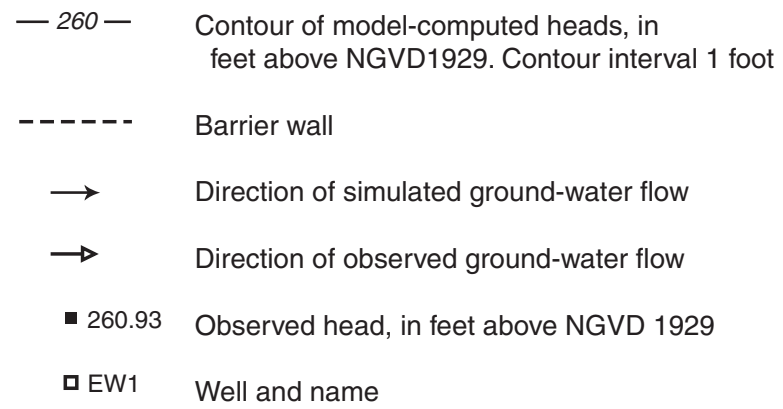

Figure 18. Contours of model-computed heads from remedial simulation and observed heads, September 1999, for model layer 4, Milford-Souhegan glacial-drift aquifer, in the OU1 part of the Savage Municipal Well Superfund site, Milford, N.H. 
A.

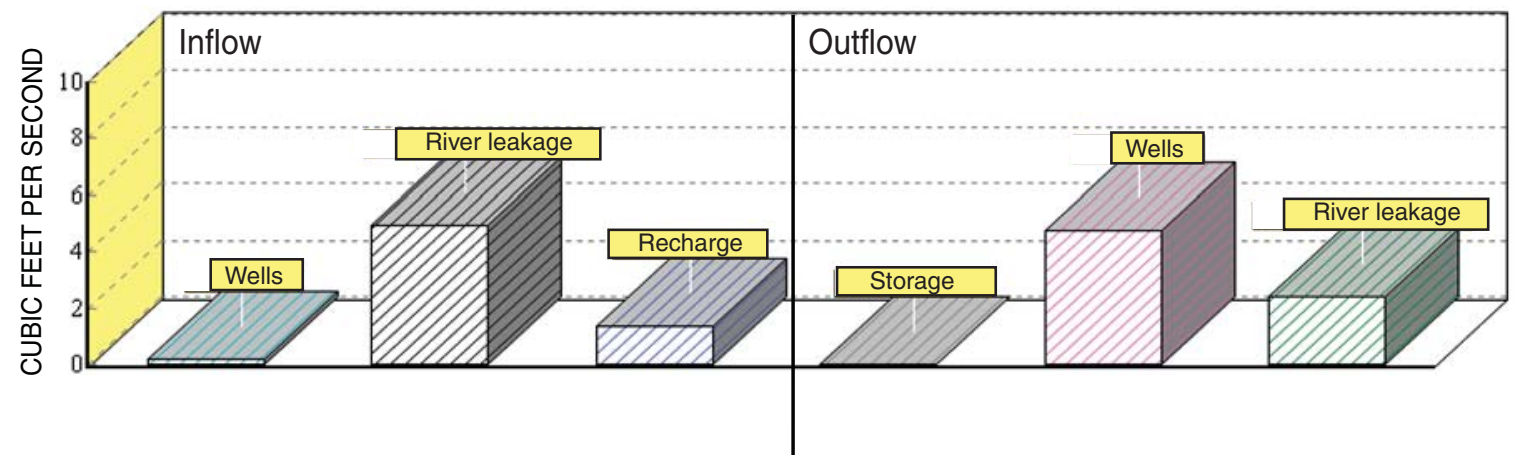

B.

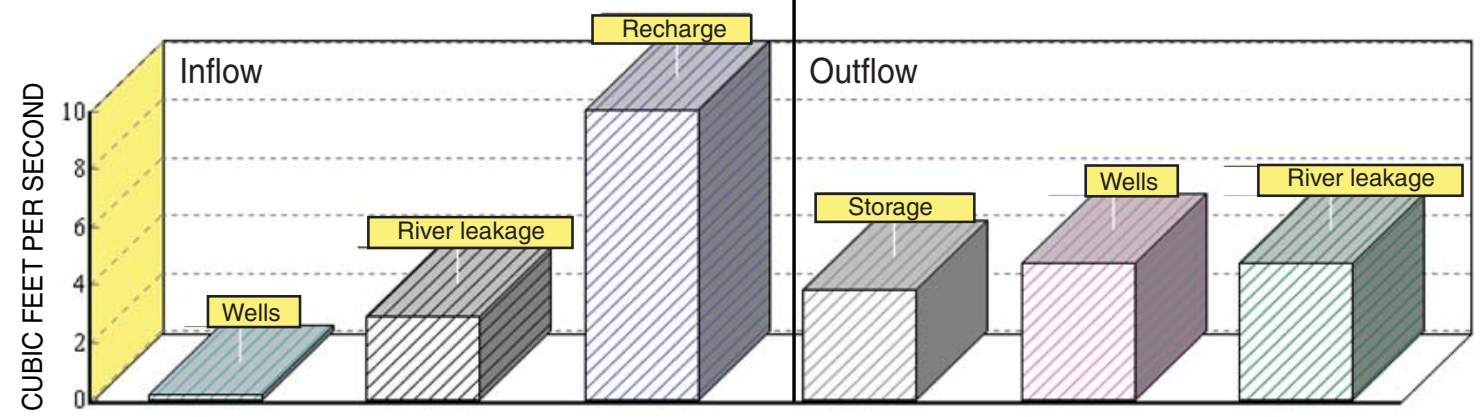

Figure 19. Simulated ground-water-flow budget for (A) August 1999 and for (B) September 1999, Milford-Souhegan glacialdrift aquifer, Savage Municipal Well Superfund site, Milford, N.H. [Storage out means an increase of storage into the aquifer.]

\section{Solute Transport}

The three-dimensional solute-transport remedial model is simulated in a subgrid of the flow model that spans from rows 53 to 140 and columns 25 to 170 , corresponding to a uniform grid area $(25 \mathrm{ft}$ by $50 \mathrm{ft})$ of the flow model. All five model layers are simulated.

The initial PCE concentrations were determined by adjusting the 1995 PCE concentrations for layers 1-5 on the basis of changes in coincident-sampled wells between 1995 and 1998 . This method was chosen because 1995 conditions included the most detailed profiling of PCE concentrations in the overburden. Changes in PCE concentrations of commonly sampled wells between 1995 and 1998 were compared to compute PCE ratios at wells and produce spatially variable ratios of concentrations of PCE. Finally, the spatially variable ratios and the starting 1995 PCE concentrations were multiplied to obtain the starting 1998 conditions. The bulk change from 1995 to 1998 (December) in the estimated dissolved mass is 2.1 to $1.2 \mathrm{Mg}$. The bulk change in sorbed mass is 3.4 to $1.5 \mathrm{Mg}$; assuming a retardation of 2 (layers $1,3,5$ ) and 2.5 (layers 2 and 4). There is no additional source of contaminant simulated for the remedial conditions other than the starting initial (1998) PCE concentrations.

The model simplifies various flow and transport processes inside the barrier. Vapor wells, which are inside the barrier and were operating sporadically during the remedial simulation period, cannot be simulated with this model. This omission introduces an error in estimating the rate of PCE mass removal (clean up) by underpredicting clean-up rates because attenuation from the vapor phase is not simulated. In contrast, a separate immiscible source also is not simulated inside the barrier. This omission produces the opposite effect by overpredicting PCE mass removal (clean-up) rates inside the barrier. To a certain extent, the effects of omitting vapor wells and input sources in the model offset the computed PCE concentrations.

The initial values for the solute-transport parameters used for the remedial similation period were obtained from the preremedial solute-transport simulations. A retardation of 2 to 2.5 was set for model layers $1,3,5$, and 2 and 4, respectively. Parts 
of layers 2 and 4 contain intervals of fine sand and would have slower flow and transport compared to the other layers. Longitudinal and transverse dispersivities were set at 54 and $12 \mathrm{ft}$, respectively. Vertical dispersivity was set at $0.1(1.2 \mathrm{ft})$ of the transverse dispersivity ( $12 \mathrm{ft}$ ) or 0.02 of the longitudinal dispersivity (54 ft). Degradation was not simulated; however, as in the pre-remedial simulation model, volatilization was simulated. Testing of alternate hydraulic conductivities, dispersivities, and retardation in remedial simulations indicated that the values obtained from the pre-remedial calibration produced the best calibration.

Model-computed concentrations of PCE were compared to observed PCE concentrations from wells in the OU1 and OU2 areas for the remedial calibration period (December 1998 to September 1999). Statistics are listed for differences between computed and observed PCE (residuals), and the relative concentration of PCE (PCE concentration at time $x$ (referenced time) divided by the initial PCE concentration) (table 8). Use of a variety of statistical measurements, such as relative concentration, helps characterize model performance. For example, measurements of differences (residuals) identify areas of the model with either large relative differences (standard mean error) or large absolute differences (absolute mean error). The use of relative concentrations as a statistical measure identifies areas of the model where computed trends (PCE changes) disagree with observed trends. Trends in PCE concentrations were analyzed further by plotting computed and observed PCE concentrations for the remedial calibration period.

Model-computed and observed PCE concentrations are spatially divided into two areas for comparison: OU1 and OU2. In OU1, comparisons are subdivided into wells inside and outside the barrier. The steep concentration gradients inside the barrier make the computed and observed concentration comparisons difficult; therefore, such comparisons were not made. Wells that are excluded from the analysis because they are inside the barrier include B95-8, B95-9, PW-10, PW-5, and PW-6 clusters (plate 2).

Several other factors discussed previously also complicate the comparison of computed and observed PCE concentrations. The high degree of vertical variation of PCE in some areas of the aquifer create a difficulty when comparing concentrations between a 20 -ft-thick cell and the 10-ft-long screened well. In OU1, some (approximately 8 wells) deep wells are hybrid wells (screened in both the overburden and bedrock) and, therefore, the reliability of the observed PCE concentration in representing the PCE concentration of the overburden is uncertain.

Model-computed PCE concentrations are generally greater than observed PCE concentrations for September 1999 in OU1. The standard mean error is $232 \mathrm{ppb}$ and the absolute mean error is $330 \mathrm{ppb}$ at 17 OU1 wells outside the barrier (table 8). PCE residual concentrations for the upper and middle model layers (layers 1-3 of the model) are generally satisfactory (PCE residuals less than $100 \mathrm{ppb}$ or differences between computed and observed PCE less than 50 percent). Computed PCE concentrations for the lowest model layers (4 and 5) compare poorly at several wells (B95-15, PW-13M, and PW-14M) but satisfactory at other wells.
A comparison of relative concentrations of PCE indicates that decreases in observed concentrations exceeded those of model-computed concentrations (table 8 ). The median relative concentrations are 0.59 and 0.81 for the observed and computed, respectively. The comparison is slightly skewed because three shallow wells (PW-12S, PW-13S, and MW-16A) with relatively low initial concentrations had computed concentrations that increased by several factors ( 2 to 9 times the initial concentrations), thereby affecting the summary statistics of mean and median computations of relative concentrations. If the three shallow wells are excluded, computed and observed PCE decreases are comparable. A likely cause of the overestimation in computed concentrations in shallow wells is a localized overestimation of vertical hydraulic conductivity or vertical dispersivity in the shallow model layers (1 and 2).

Graphs of model-computed concentrations of PCE were generated and values compared to observed PCE concentrations for selected, geographically distributed wells in OU1 (figs. 2021). Concentrations of TCE, cis-1,2-DCE, TCE, and cis-1,2DCE were included to ensure that secondary contaminants, which potentially are formed from the degradation of PCE, are not being accumulated in the overburden. Accumulation of TCE and cis-1,2-DCE concentrations would indicate that a sequential simulation of contaminants is needed in the model. At most overburden wells, observed data show no accumulation of TCE or cis-1,2-DCE.

The similarity of time trends between computed and observed PCE concentrations is satisfactory at most wells. At well B95-13 (fig. 20a), near extraction wells EW-1 and EW-2, decreases in computed PCE closely match observed PCE concentrations. Secondary contaminants, TCE and cis-1,2-DCE, show similar downward trends as PCE and indicate that these contaminants are not accumulating. At well PW-13M (fig. 20b), at the OU1-OU2 boundary (fig. 3), computed PCE concentrations exceed those of observed PCE concentrations but trends are similar. At well PW-14M (fig. 21a), at the OU1-OU2 boundary, computed PCE concentrations exceeded observed PCE concentrations but both concentrations had similar downward trends; the computed relative PCE concentration is 1.0 and the observed relative PCE concentration is 0.88 . A high relative concentration indicates a small decrease in PCE concentrations from December 1998 to September 1999. At well MW-16B (fig. 21), also at the OU1-OU2 boundary, computed PCE concentrations increase slightly but observed PCE concentrations remain static.

Differences in model-computed and observed PCE concentrations are evenly distributed around zero for the 19 OU2 area wells (table 9). The standard mean error is $-12 \mathrm{ppb}$, which indicates that the model computes, on average, similar PCE concentrations to those observed in the field. The absolute mean error is $200 \mathrm{ppb}$. The largest difference is at well MW-20B (-574 ppb). At wells MW-13A and MW-101C, differences are also large, but are likely caused by differences in vertical distribution of PCE. Computed PCE concentrations are lower (-520 ppb) than observed at shallow cluster well MW-13A, but higher (444 ppb) than observed at deep cluster well MW13B and the overall difference at this location is small (-76 ppb). 
Table 8. Differences between model-computed tetrachloroethylene (PCE) concentrations and observed PCE concentrations for September 1999 in 0U1, Savage Municipal Well Superfund Site, Milford, N.H.

[All concentrations are in parts per billion (ppb); negative difference means observed PCE greater than model-computed PCE; wells ranked by observed PCE concentration, September 1999; --, no data; C = PCE from September 1999; Co = PCE from December 1998. Well locations are shown on plate 2.]

\begin{tabular}{|c|c|c|c|c|c|c|c|c|c|c|c|c|}
\hline \multirow[b]{3}{*}{$\begin{array}{l}\text { Well } \\
\text { name }\end{array}$} & \multirow[b]{3}{*}{$\begin{array}{c}\text { Well } \\
\text { number }\end{array}$} & \multirow[b]{3}{*}{$\begin{array}{l}\text { Easting, } \\
\text { State Planar } \\
\text { in feet }\end{array}$} & \multirow[b]{3}{*}{$\begin{array}{l}\text { Northing, } \\
\text { State Planar } \\
\text { in feet }\end{array}$} & \multirow[b]{3}{*}{$\begin{array}{c}\text { Model } \\
\text { layer }\end{array}$} & \multicolumn{4}{|c|}{ Concentration of PCE } & \multicolumn{3}{|c|}{ Relative PCE change in concentration } & \multirow[b]{3}{*}{ Comments } \\
\hline & & & & & \multicolumn{2}{|c|}{ Observed } & \multirow{2}{*}{$\begin{array}{c}\begin{array}{c}\text { Model- } \\
\text { computed }\end{array} \\
\begin{array}{c}\text { Septem- } \\
\text { ber } \\
1999\end{array}\end{array}$} & \multirow[b]{2}{*}{$\begin{array}{c}\text { Differ- } \\
\text { ence for } \\
\text { Septem- } \\
\text { ber } 1999\end{array}$} & \multicolumn{3}{|c|}{ C/Co } & \\
\hline & & & & & $\begin{array}{l}\text { Decem- } \\
\text { ber } \\
1998\end{array}$ & $\begin{array}{c}\text { Septem- } \\
\text { ber } \\
1999\end{array}$ & & & $\begin{array}{c}\text { Model } \\
\text { computed }\end{array}$ & Observed & $\begin{array}{c}\text { Difference } \\
\text { between model- } \\
\text { computed and } \\
\text { observed }\end{array}$ & \\
\hline PW-12S & 555 & 975432.0 & 125281.0 & 2 & 10 & 21 & 58 & 37 & 4.49 & 2.10 & 2.39 & \multirow{5}{*}{ Observed PCE from October 1999.} \\
\hline PW-13S & 559 & 975682.0 & 125294.0 & 2 & 94 & 41 & 109 & 68 & 9.51 & .44 & 9.08 & \\
\hline MW-16A & 233 & 975671.2 & 124863.1 & 1 & 60 & 58 & 376 & 318 & 2.44 & .99 & 1.45 & \\
\hline B95-15 & 409 & 975254.0 & 125149.4 & 5 & 410 & 82 & 496 & 414 & .65 & .20 & .45 & \\
\hline PW-13M & 560 & 975682.1 & 125294.1 & 4 & 560 & 120 & 615 & 495 & .48 & .21 & .26 & \\
\hline MW-16B & 321 & 975671.0 & 124868.6 & 3 & 310 & 320 & 421 & 101 & 2.58 & 1.03 & 1.55 & \multirow{5}{*}{ Observed PCE from October 1999.} \\
\hline PW12D & 557 & 975432.2 & 125281.2 & 5 & 700 & 380 & 589 & 209 & .62 & .54 & .07 & \\
\hline PW12M & 556 & 975437.2 & 125255.7 & 4 & 700 & 410 & 292 & -118 & .31 & .58 & -.28 & \\
\hline PW2S & 532 & 975245.0 & 124965.0 & 2 & 1,400 & 530 & 1,087 & 557 & .75 & .38 & .37 & \\
\hline PW-14S & 562 & 975765.0 & 125085.0 & 2 & 950 & 640 & 1,050 & 410 & 1.14 & .67 & .46 & \\
\hline B95-13 & 408 & 975490.6 & 125002.0 & 4 & 2,000 & 690 & 1,236 & 546 & .52 & .35 & .17 & \multirow{7}{*}{ Observed PCE from October 1999.} \\
\hline MW-16C & 344 & 975678.1 & 124877.1 & 4 & 1,500 & 860 & 671 & -189 & .63 & .57 & .06 & \\
\hline PW2M & 533 & 975245.1 & 124965.1 & 3 & 1,600 & 950 & 962 & 12 & .62 & .59 & .03 & \\
\hline PW2D & 534 & 975245.2 & 124965.2 & 5 & 1,700 & 1,000 & 1,613 & 613 & 1.00 & .59 & .41 & \\
\hline PW-14M & 563 & 975765.1 & 125085.1 & 4 & 1,250 & 1,100 & 2,041 & 941 & .99 & .88 & .11 & \\
\hline PW-13D & 561 & 975682.2 & 125294.2 & 5 & 1,100 & 1,000 & 1,055 & 55 & .81 & .91 & -.28 & \\
\hline \multirow[t]{4}{*}{ PW-14D } & 564 & 975765.2 & 125085.2 & 5 & 1,750 & 2,700 & 2,179 & -521 & 1.06 & 1.54 & -.49 & \\
\hline & & & & & & & $\begin{array}{r}\text { Stan- } \\
\text { dard } \\
\text { Mean } \\
\text { Error }\end{array}$ & 232 & 1.68 & 0.74 & 0.93 & \\
\hline & & & & & & & $\begin{array}{r}\text { Absolute } \\
\text { Mean } \\
\text { Error }\end{array}$ & 330 & -- & -- & -- & \\
\hline & & & & & & & Median & 209 & 0.81 & 0.59 & 0.26 & \\
\hline
\end{tabular}


A.

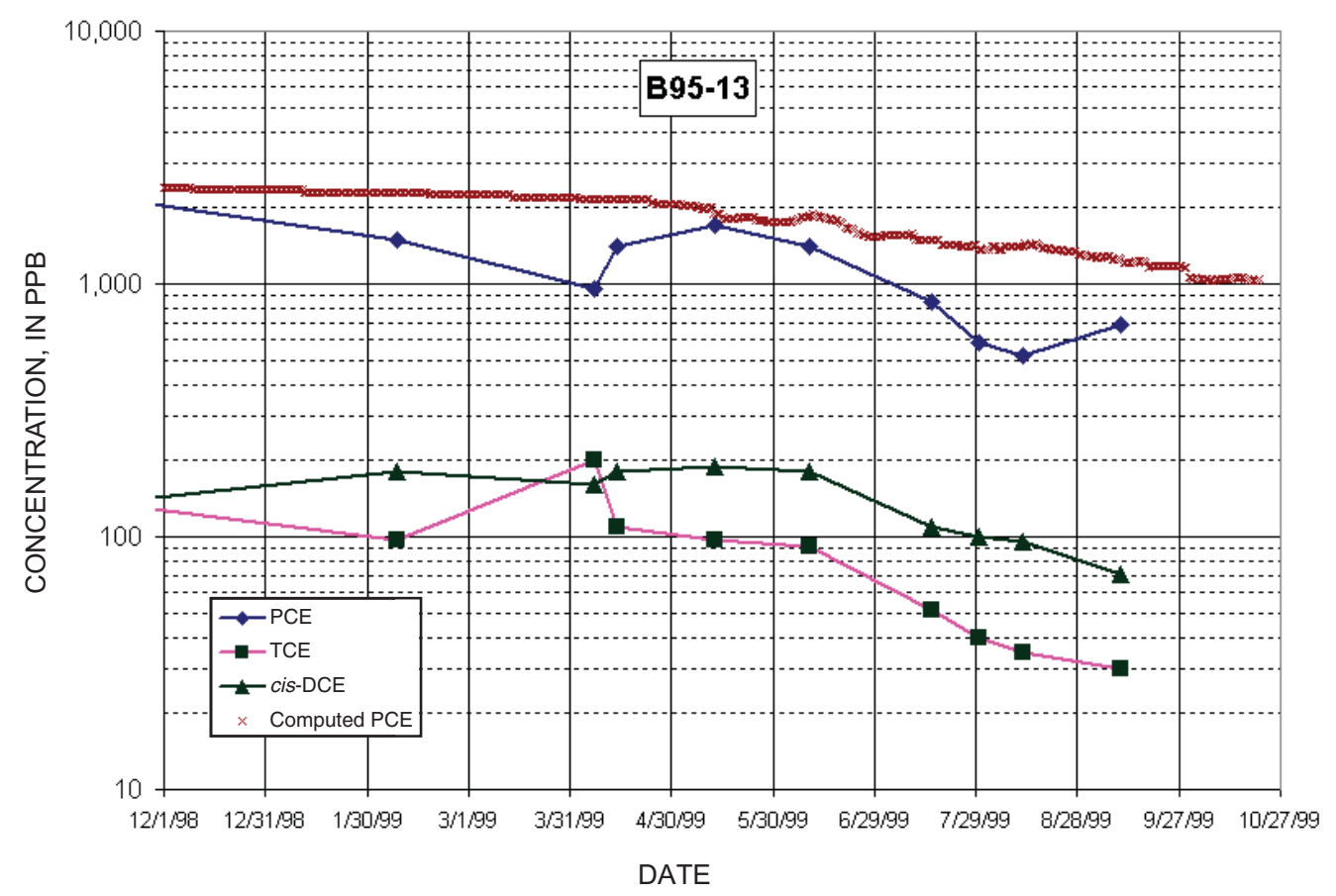

B.

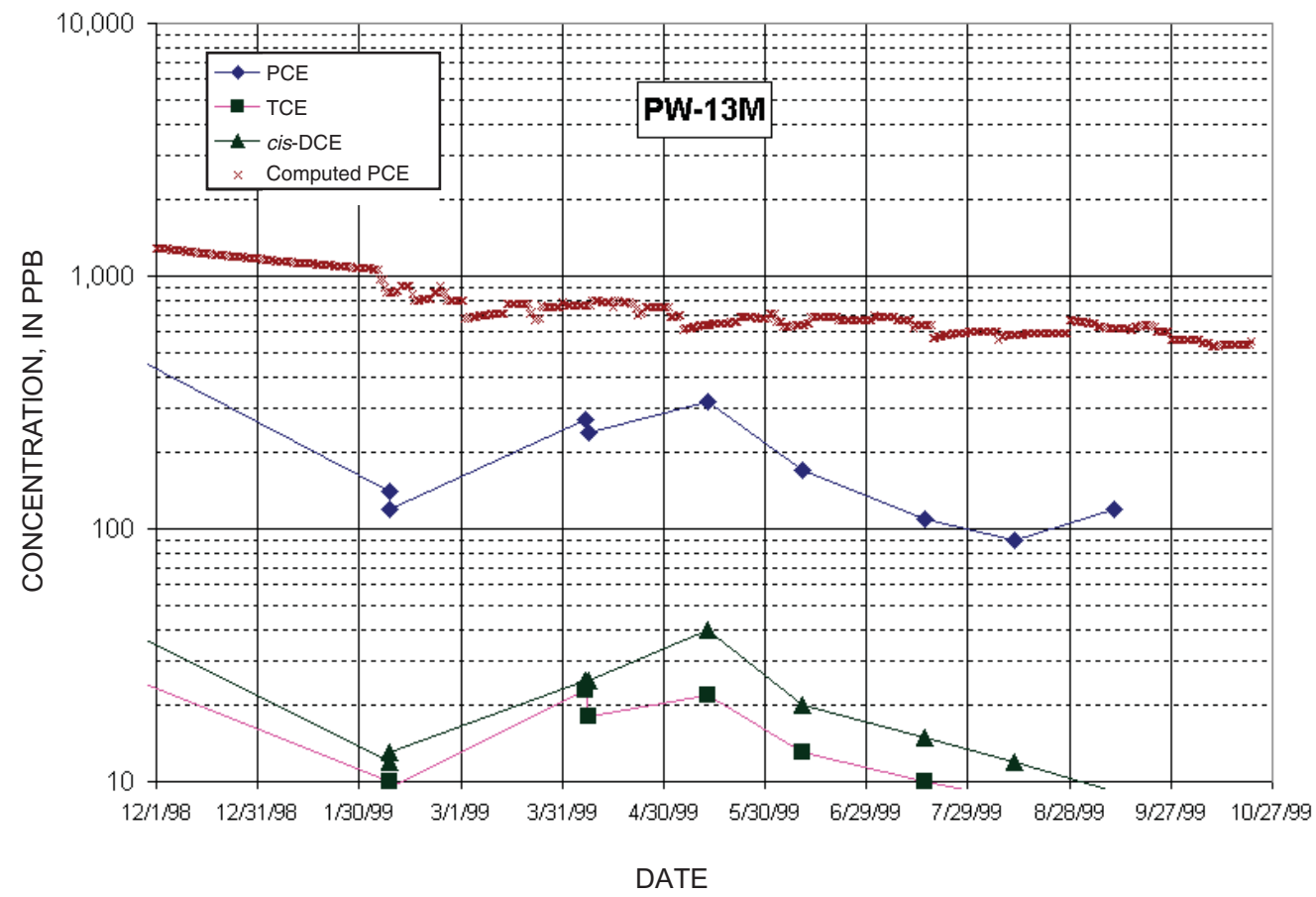

Figure 20. Model-computed tetrachloroethylene (PCE) concentrations and observed concentrations for PCE, trichloroethylene (TCE), and cis-1,2-dichloroethylene (cis-DCE) for wells (A) B95-13, and (B) PW-13M in the OU1 part of the Savage Municipal Well Superfund site, Milford, N.H. (Concentrations in parts per billion ( $\mathrm{ppb})$ and well locations shown on figure 3.) 
A.

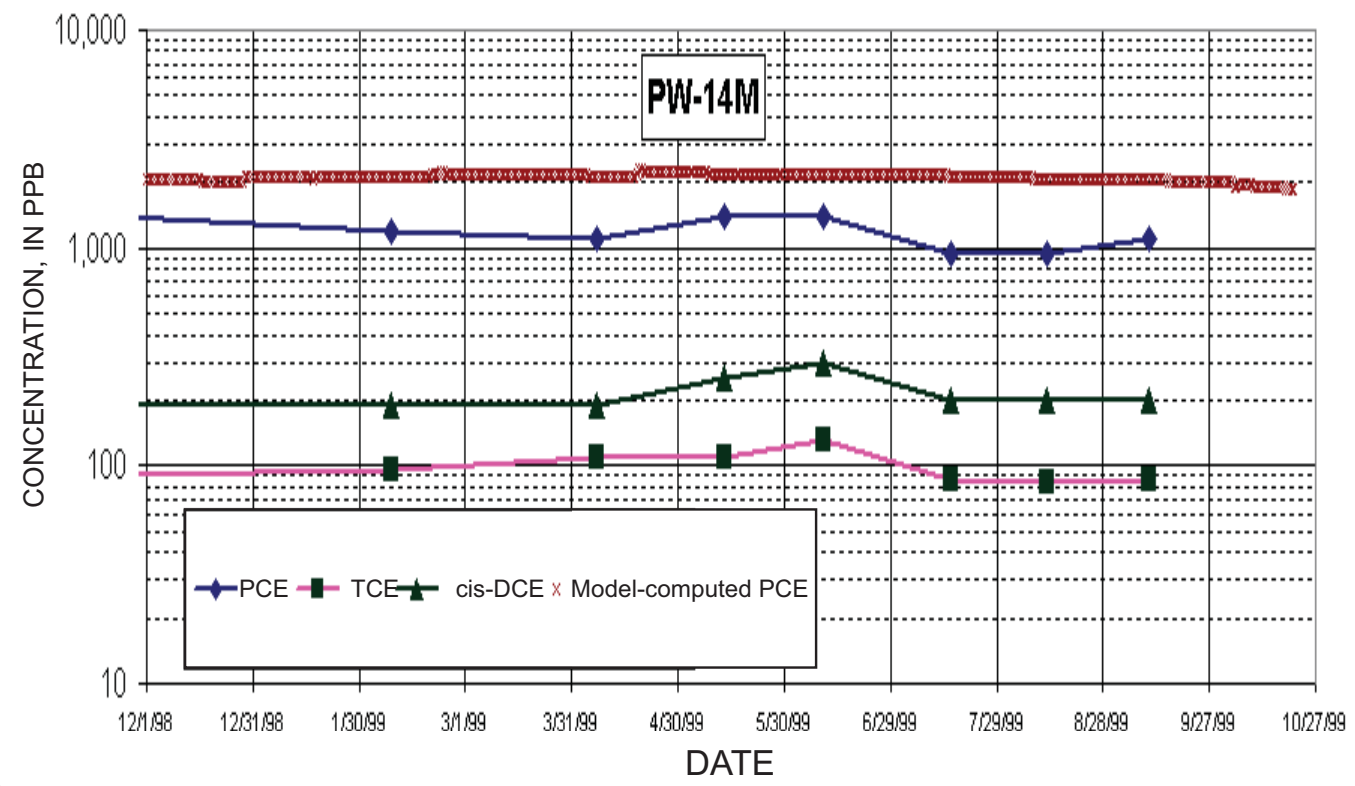

B.

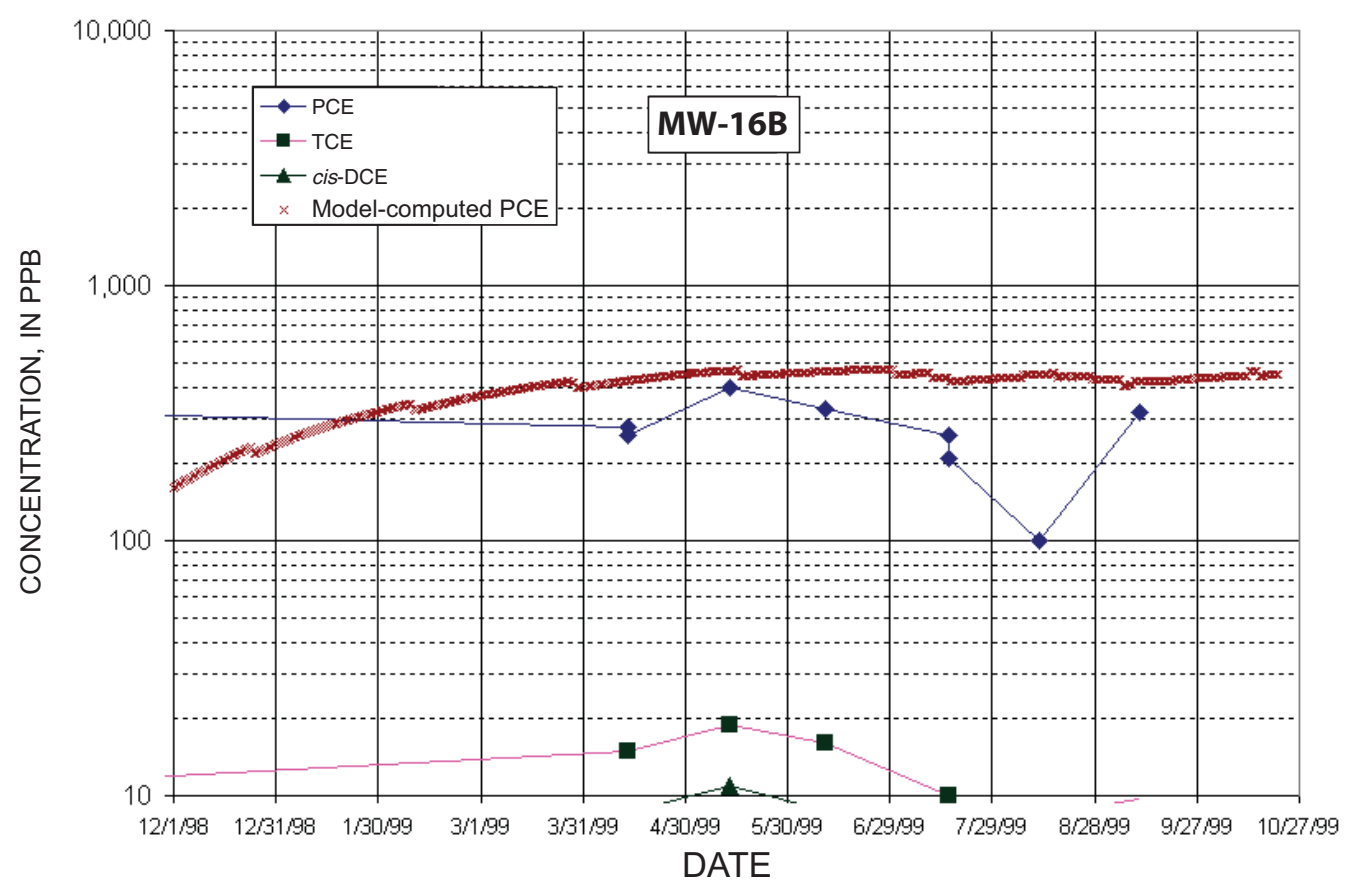

Figure 21. Model-computed tetrachloroethylene (PCE) concentrations and observed concentrations for PCE, trichloroethylene (TCE), and cis-1,2-dichloroethylene (cis-DCE) for wells (A) PW-14M, and (B) MW-16B in the OU1 part of the Savage Municipal Well Superfund site, Milford, N.H. (Concentrations in parts per billion (ppb) and well locations shown on figure 3.) 
Table 9. Differences between model-computed tetrachloroethylene (PCE) concentrations and observed PCE concentrations for September 1999 in OU2, Savage Municipal Well Superfund Site, Milford, N.H.

[All concentrations are in parts per billion (ppb); negative difference means observed PCE greater than model-computed PCE; wells ranked by observed PCE concentration, September 1999; --, no data; C = PCE from September 1999; Co = PCE from December 1998. Well locations are shown on plate 2.]

\begin{tabular}{|c|c|c|c|c|c|c|c|c|c|c|c|c|}
\hline \multirow[b]{3}{*}{ Well name } & \multirow[b]{3}{*}{$\begin{array}{c}\text { Well } \\
\text { number }\end{array}$} & \multirow[b]{3}{*}{$\begin{array}{l}\text { Easting, } \\
\text { State Planar } \\
\text { in feet }\end{array}$} & \multirow[b]{3}{*}{$\begin{array}{l}\text { Northing, } \\
\text { State Planar } \\
\text { in feet }\end{array}$} & \multirow[b]{3}{*}{$\begin{array}{l}\text { Model } \\
\text { layer }\end{array}$} & \multicolumn{4}{|c|}{ Concentration of PCE } & \multicolumn{3}{|c|}{ Relative PCE change in concentration } & \multirow[b]{3}{*}{ Comments } \\
\hline & & & & & \multicolumn{2}{|c|}{ Observed } & \multirow{2}{*}{$\begin{array}{c}\begin{array}{c}\text { Model- } \\
\text { computed }\end{array} \\
\begin{array}{c}\text { September } \\
1999\end{array}\end{array}$} & \multirow[b]{2}{*}{$\begin{array}{c}\text { Difference for } \\
\text { September } \\
1999\end{array}$} & \multicolumn{3}{|c|}{ C/Co } & \\
\hline & & & & & $\begin{array}{l}\text { December } \\
1998\end{array}$ & $\begin{array}{c}\text { September } \\
1999\end{array}$ & & & $\begin{array}{c}\text { Model } \\
\text { computed }\end{array}$ & Observed & $\begin{array}{l}\text { Difference between } \\
\text { model-computed } \\
\text { and observed }\end{array}$ & \\
\hline MW-101A & 580 & 975981.9 & 125600.9 & 1 & 20 & 1 & 61 & 60 & 4.03 & 0.04 & 3.99 & \multirow{19}{*}{$\begin{array}{l}\text { Initial model-computed } \\
\text { PCE equal to zero. }\end{array}$} \\
\hline MW20A & 264 & 977472.9 & 124629.1 & 2 & 11 & 9 & 128 & 119 & 11.09 & .82 & 10.27 & \\
\hline MW-101B & 581 & 975984.5 & 125594.2 & 3 & 20 & 10 & 317 & 307 & 27.95 & .50 & 27.45 & \\
\hline MW9C & 217 & 976503.3 & 124473.6 & 5 & 21 & 18 & 44 & 26 & .81 & .86 & -.04 & \\
\hline MW21C & 330 & 979001.5 & 124474.0 & 3 & 20 & 18 & 0 & -18 & -- & -- & -- & \\
\hline MW9B & 352 & 976503.6 & 124479.1 & 3 & 44 & 34 & 18 & -16 & 1.22 & .77 & .45 & \\
\hline MW9A & 351 & 976502.9 & 124485.8 & 2 & 50 & 37 & 16 & -21 & .75 & .74 & .01 & \\
\hline MW11B & 319 & 976435.2 & 125885.3 & 4 & 41 & 39 & 233 & 194 & 6.34 & .95 & 5.39 & \\
\hline MW11A & 318 & 976433.3 & 125888.7 & 2 & 87 & 67 & 155 & 88 & 1.13 & .77 & .36 & \\
\hline MW10A & 316 & 976221.5 & 124928.6 & 2 & 42 & 70 & 135 & 65 & 2.13 & 1.67 & .46 & \\
\hline MW10B & 317 & 976218.5 & 124928.4 & 3 & 82 & 85 & 200 & 115 & 1.94 & 1.04 & .91 & \\
\hline MW14B & 341 & 978696.6 & 125651.1 & 3 & 500 & 240 & 497 & 257 & .92 & .48 & .44 & \\
\hline MI-8 & 22 & 976549.9 & 125251.5 & 1 & 280 & 260 & 371 & 111 & -- & .93 & -- & \\
\hline MW13B & 221 & 977300.6 & 125081.1 & 3 & 430 & 370 & 814 & 444 & 1.50 & .86 & .64 & \\
\hline MW14A & 349 & 978695.9 & 125654.9 & 2 & 495 & 520 & 283 & -237 & .70 & 1.05 & -.35 & \\
\hline MW10C & 218 & 976215.0 & 124930.6 & 5 & 320 & 570 & 340 & -230 & .89 & 1.78 & -.90 & \\
\hline MW20B & 328 & 977476.1 & 124622.3 & 3 & 860 & 700 & 126 & -574 & .10 & .81 & -.71 & \\
\hline MW13A & 308 & 977298.8 & 125084.8 & 2 & 850 & 1,100 & 580 & -520 & .55 & 1.29 & -.75 & \\
\hline \multirow[t]{4}{*}{ MW-101C } & 582 & 975985.1 & 125588.7 & 5 & 970 & 1,200 & 796 & -404 & 1.48 & 1.24 & .25 & \\
\hline & & & & & & & $\begin{array}{r}\text { Standard } \\
\text { Mean Error }\end{array}$ & -12 & 3.74 & 0.92 & 2.82 & \\
\hline & & & & & & & $\begin{array}{r}\text { Absolute } \\
\text { Mean Error }\end{array}$ & 200 & -- & -- & -- & \\
\hline & & & & & & & Median & 60 & 1.22 & 0.86 & 0.44 & \\
\hline
\end{tabular}


At the MW-101 cluster, the overall difference also is small (-37 ppb), but computed PCE concentrations are higher than observed concentrations for the shallow cluster wells (MW-101A, difference of $60 \mathrm{ppb}$; and MW-101B, difference of $307 \mathrm{ppb}$ ) and lower than observed for the deep well (MW-101C, difference of $-404 \mathrm{ppb}$ ).

Relative PCE changes for OU2 wells show that at some wells model-computed PCE concentrations increased and observed PCE concentrations decreased. The median computed relative concentration is 1.22 but the median observed relative concentration is 0.86 . Large relative changes in computed concentrations occurred at MW-11B (6.34) and MW-101B (27.95) and result from vertically overmixing PCE concentrations in the model simulation.

Graphs of model-computed PCE were generated and compared to observed PCE concentrations for selected, geographically distributed wells in the OU2 area (figs. 22-23). These graphs also include plots of observed concentrations of TCE and total DCE or cis-1,2-DCE (concentrations of total DCE and cis-1,2-DCE are similar at the Savage site). At almost all overburden wells, observed data show no accumulation of TCE, and cis-1,2-DCE or total DCE.

Model-computed PCE trends compare favorably (similar trends) with observed PCE trends at wells MW-101C (along northern part of the plume) and MW-14A (at the leading edge of the plume; fig. 23). At wells MW-11B and MW-20B, computed PCE concentrations compare poorly (dissimilar trends) with observed PCE concentrations (fig. 22). Although computed PCE increases by an order of magnitude at MW-11B, along the northern edge of the plume, observed PCE concentrations show no apparent trend. At MW-20B, along the southern edge of the plume, computed PCE concentrations decrease by an order of magnitude, and observed concentrations decrease much less.

The effects of specifying a high retardation in model simulation were tested to evaluate if an improved fit could be obtained at MW-20B and the MW-11 cluster. Increasing retardation (globally) to a value of 6 (from 2 to 2.5) had a negligible effect at these locations; indicating that factors other than retardation may be the cause for the large residual concentrations. At the MW-11 cluster, relatively large increases in observed PCE concentrations (by a factor of 10) have been measured in the bedrock (MW-11R), indicating the possibility of PCE transport from the overburden to the bedrock, which is not simulated in the model. At MW-20B, it appears that the initial starting mass assigned to the model is less than the actual PCE mass in the field and(or) other sources of PCE may be present near the southern part of the plume that would contribute to the slow decrease in observed concentrations at MW-20B. Differences between computed and observed PCE concentrations also could be caused by small inaccuracies in the simulated flowpaths near MW-20B because the well is along the southern edge of the plume, where large concentration gradients are present.
The solute-transport budget for the remedial period indicates that the remedial extraction wells in OU1 capture a decreasing amount of PCE mass over time as the amount of remaining PCE mass (residual mass) in OU1 also decreases. The simulated PCE mass captured by the OU1 extraction wells decreases from a rate of $0.25 \mathrm{Mg} / \mathrm{yr}$ in May 1999 (the beginning of operation) to $0.16 \mathrm{Mg} / \mathrm{yr}$ in September 1999 . The variation in mass of PCE discharging to the Souhegan River is primarily a function of transient hydrologic conditions rather than a decreasing residual PCE mass. The simulated rate of PCE mass discharged to rivers varied little from May 1999 (a rate of $0.26 \mathrm{Mg} / \mathrm{yr}$ ) to August 1999 (a rate of $0.24 \mathrm{Mg} / \mathrm{yr}$ ), when the applied recharge ranged from 0.63 to $2.18 \mathrm{in} / \mathrm{mo}$. In September 1999 , PCE mass discharge increased to a rate of $0.33 \mathrm{Mg} / \mathrm{yr}$ as a result of increased recharge to the aquifer (a recharge rate of $6.9 \mathrm{in} / \mathrm{mo}$ ) that accelerated transport and discharge of PCE at the leading edge of the plume where it discharges to the Souhegan River. PCE mass being attenuated from volatilization ranged from a rate of $6.4 \times 10^{-4} \mathrm{Mg} / \mathrm{yr}$ in May 1999 to $5.9 \times 10^{-4} \mathrm{Mg} / \mathrm{yr}$ in September 1999. PCE mass discharging past the subgrid boundary ranged from $0.210 \mathrm{Mg} / \mathrm{yr}$ in May 1999 to $0.20 \mathrm{Mg} / \mathrm{yr}$ in August 1999. In September 1999, PCE mass discharging past the subgrid boundary increased to a rate of $0.25 \mathrm{Mg} / \mathrm{yr}$ as a result of increased recharge to the aquifer and accelerated transport of PCE.

The alternative hydraulic conductivities tested in the model resulted in small changes to the solute-transport budget. Increasing horizontal hydraulic conductivities in layer 5 by a factor of 3 resulted in slightly less mass (about 1 percent change) being captured by OU1 extraction wells and more mass discharging to the river. Conversely, decreasing horizontal hydraulic conductivities in layer 2 had the opposite effect.

The alternative hydraulic conductivities tested in the model resulted in increased PCE residuals for layer 5 but decreased residuals for layer 2 . Increasing horizontal hydraulic conductivities in layer 5 by a factor of 3 resulted in the model overpredicting decreases in PCE concentrations. The model sensitivity to the alternate hydraulic conductivities were spatially dependent. Wells at the OU1/OU2 boundary were sensitive to the hydraulic conductivities tested, but wells closet to the barrier were less sensitive because of (1) the slow velocity zone that is created by the downgradient shadow of the barrier, and (2) a tendency of the model to overestimate solute transport across the barrier.

Testing of variations in retardation showed that modelcomputed PCE concentrations are less sensitive to variations in retardation than hydraulic conductivity. The ratio of relative concentrations (current/initial) at wells along the OU1/OU2 boundary changed by 5 percent (a factor of only 0.05 ) when a retardation value of 6 was assigned instead of the baseline value of 2-2.5. In contrast, tested variations in hydraulic conductivity resulted in a 20-percent (a factor of 0.20) change in relative concentrations for the same wells. 
A.

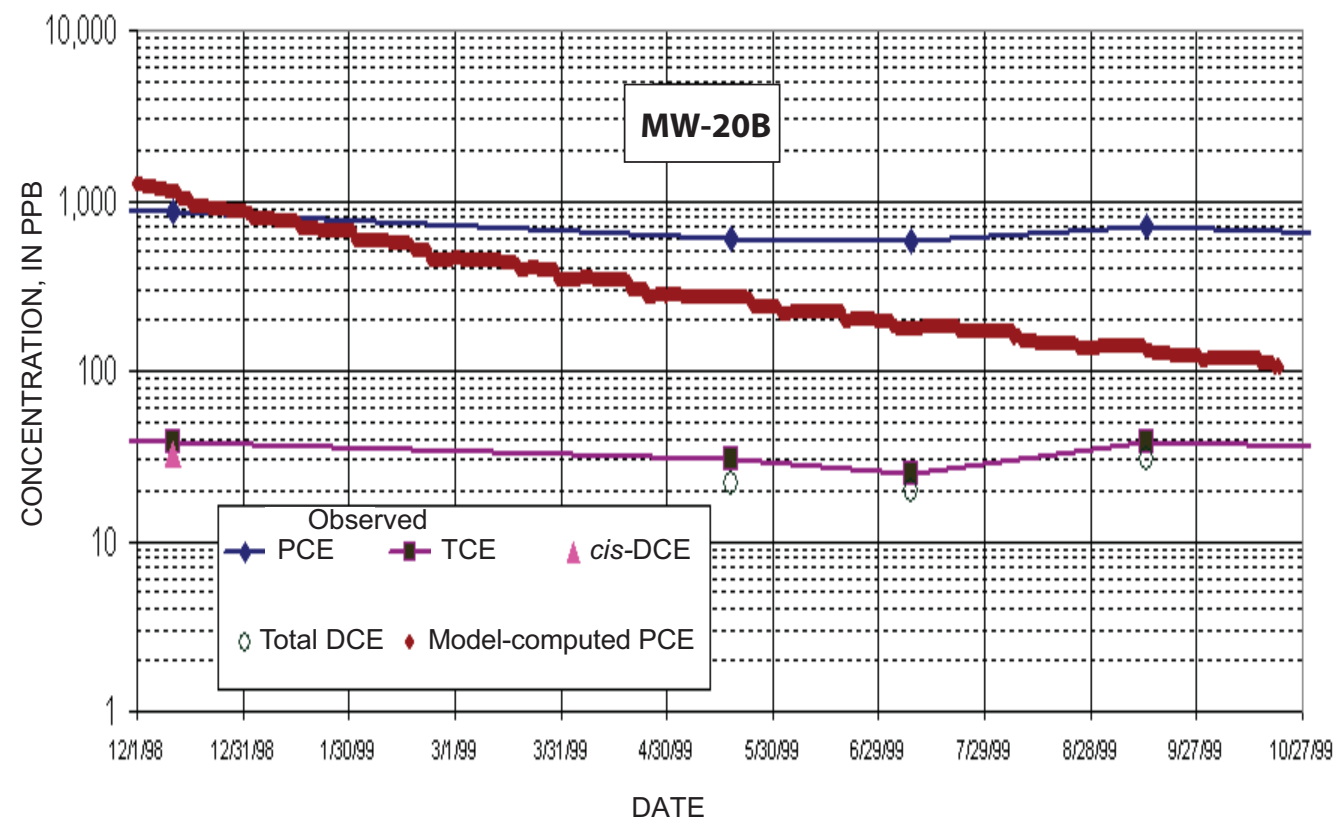

B.

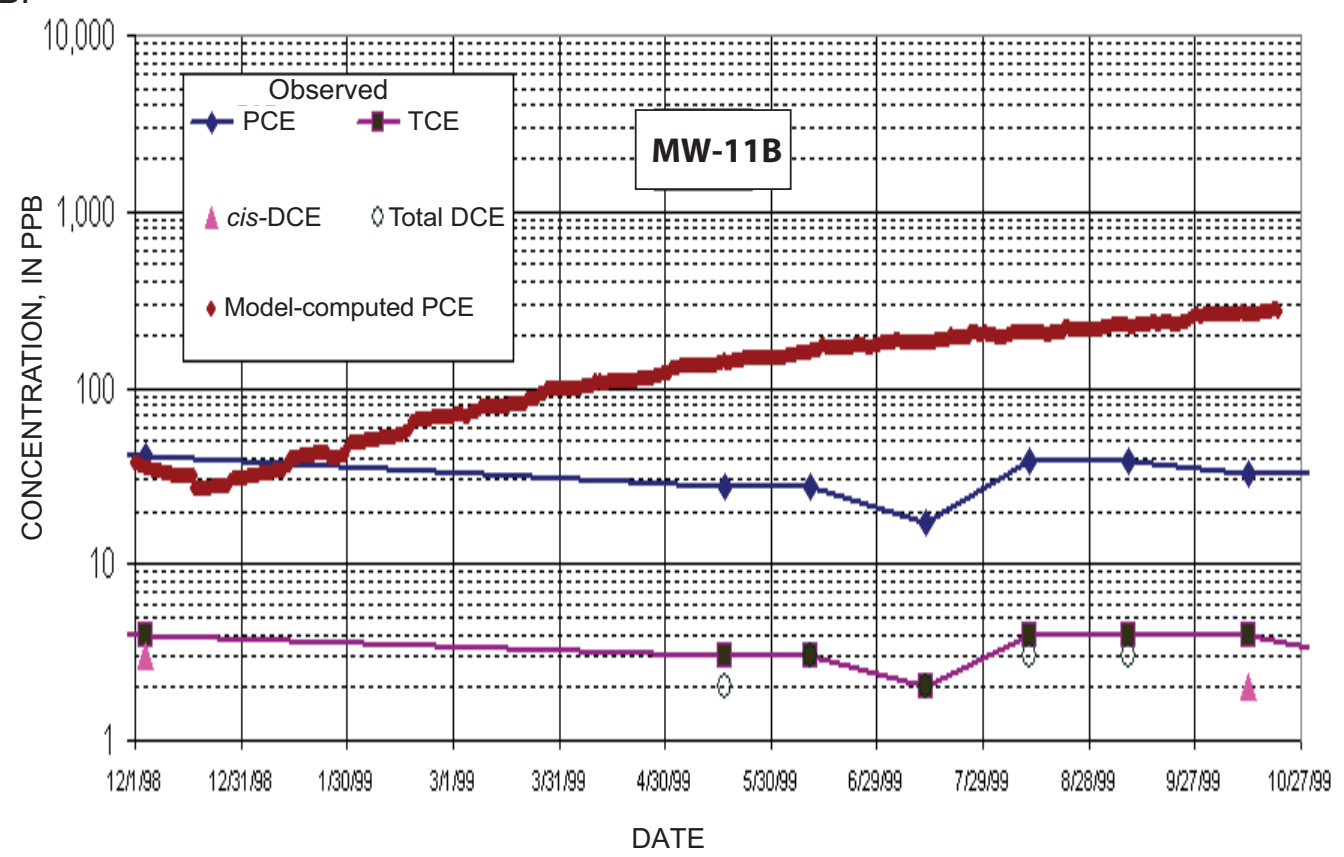

Figure 22. Model-computed tetrachloroethylene (PCE) concentrations and observed concentrations for PCE, trichloroethylene (TCE), and cis-1,2-dichloroethylene (cis-DCE) for wells (A) MW-20B, and (B) MW-11B in the OU2 part of the Savage Municipal Well Superfund site, Milford, N.H. (Concentrations in parts per billion (ppb) and well locations shown on figure 3.) 


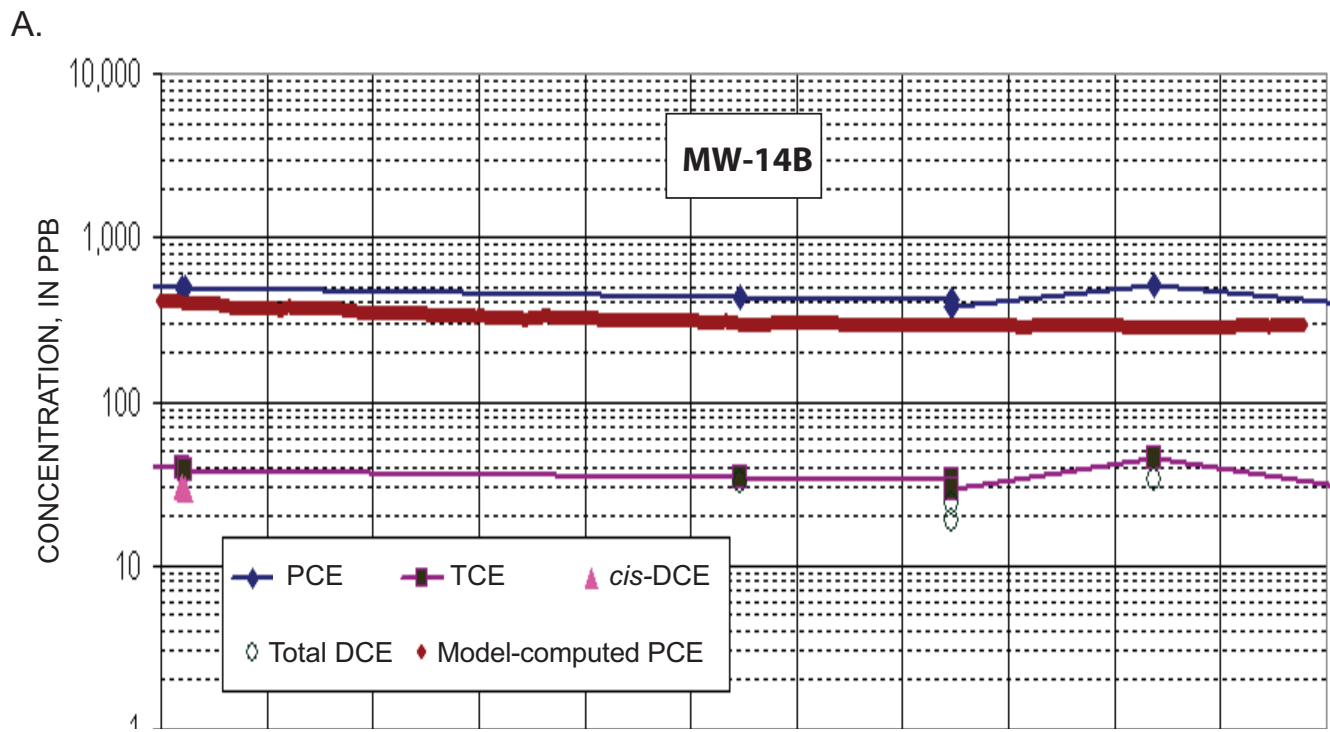

DATE

B.

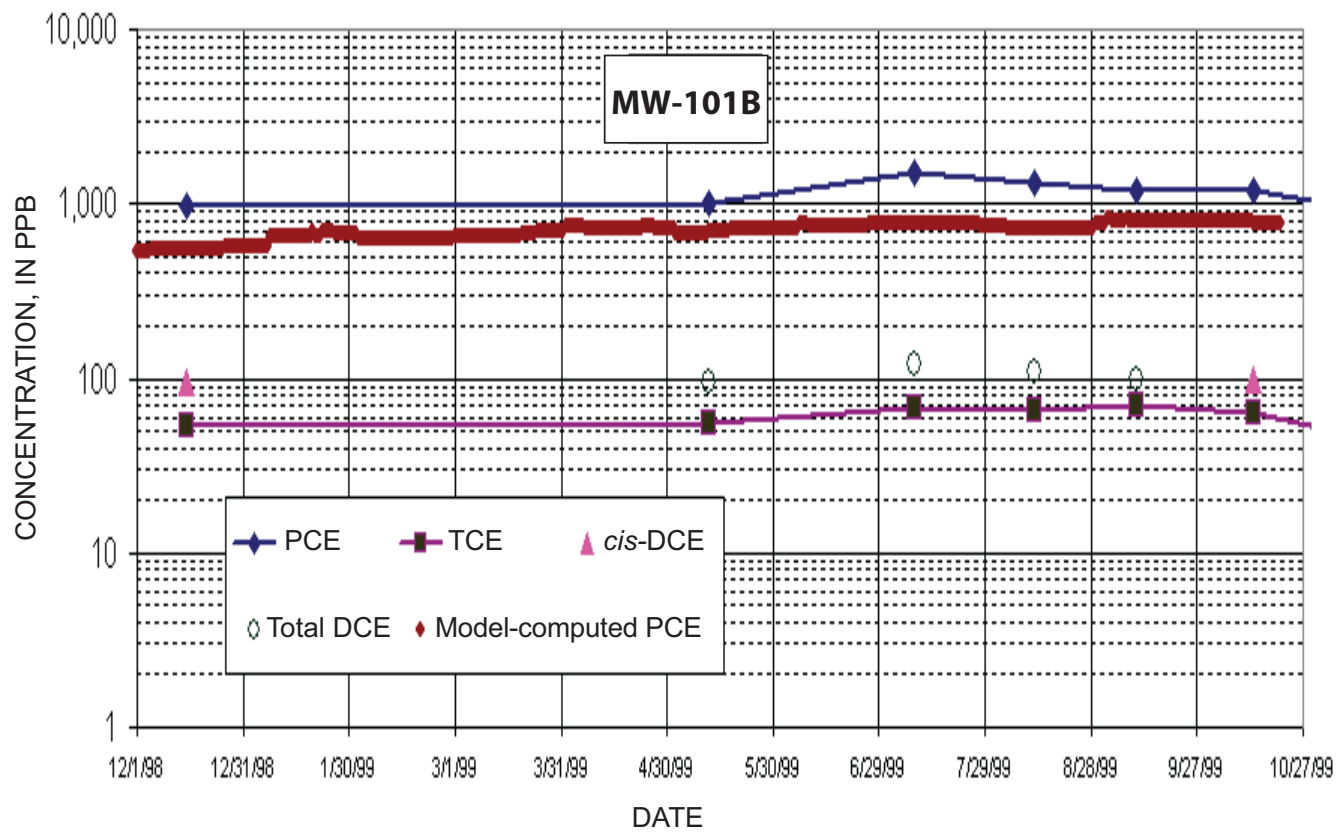

Figure 23. Model-computed tetrachloroethylene (PCE) concentrations and observed concentrations for PCE, trichloroethylene (TCE), and cis-1,2-dichloroethylene (cis-DCE) for wells (A) MW-14A, and (B) MW$101 \mathrm{C}$ in the OU2 part of the Savage Municipal Well Superfund site, Milford, N.H. (Concentrations in parts per billion (ppb) and well locations shown on figure 3.) 


\section{Analysis of Extended Time Period}

The calibrated remedial model was used in a simulation of an extended time period beyond September 1999 (the end of the remedial calibration period) to compare computed PCE concentrations against observed PCE concentrations from 2000. This check helped to assess the performance of the calibrated model. Computed PCE concentrations were compared to concentrations from two sampling dates in 2000, and included wells in the OU1 (May) and OU2 (June) areas.

Differences between model-computed and observed PCE concentrations for 23 OU1 wells in May 2000 are provided in table 10. Wells are tabulated in order of ascending observed concentration. Statistics listed include standard mean error, absolute mean error, and the relative concentrations of PCE (PCE concentration at time $x$ (referenced time) divided by the initial PCE concentration).

For the extended time period, model-computed PCE concentrations generally exceed observed PCE concentrations. The standard mean error is $228 \mathrm{ppb}$ (on average, computed concentrations are greater than observed concentrations) and the absolute mean error is $323 \mathrm{ppb}$. All but three wells have computed concentrations that exceed observed concentrations.

Differences in PCE concentrations are large (greater than $+500 \mathrm{ppb}$ ) at seven wells-PW-14M, PW-14D, PW-2S, PW2M, PW-2D, PW-1D, and B95-13. Most of these wells are installed in the deep part of the overburden (layers 4 and 5) where PCE concentrations are the highest. Three wells are close to the barrier (PW-2S, PW-2M, PW-2D, fig. 3). Well PW-2S is the only shallow well with a large residual error. The observed relative concentration at $\mathrm{PW}-2 \mathrm{~S}$ decreased to 0.02 and the model-computed relative concentration decreased to 0.51 . Because this well is directly outside and downgradient of the barrier, this large discrepancy indicates that the model is either overestimating PCE transport through the barrier and(or) underestimating the rate of flushing by relatively "clean" water on the outside of the barrier.

The PW-13 and PW-14 clusters are important observation wells because they are at the downgradient edge of OU1 (fig. 3) and measure the amount of solute transport of PCE to OU2. The relative computed PCE concentrations show slightly more of a decrease at wells PW-13D (0.67) and PW-14D (1.02) than the relative observed PCE concentrations (PW-13D (1.0) and PW14D (1.54)).

Differences in model-computed and observed PCE concentrations for 34 extended plume area (OU2) wells in June 2000 are provided in table 11 . The standard mean error is $-19 \mathrm{ppb}$ and indicates that observed concentrations slightly exceed computed concentrations. The absolute mean error is $158 \mathrm{ppb}$. The median difference is $-3 \mathrm{ppb}$.

Although there are large differences between modelcomputed and observed PCE concentrations at some wells, PCE trends match at many wells. For example, at well MW-101C, the observed concentration is $546 \mathrm{ppb}$ higher than the computed concentration (table 11). However, the change in PCE is similar between computed (1.41) and observed (1.34) relative concentration. The similarity in computed and observed trends at other wells is evident by the agreement in median relative PCE concentrations (computed 1.1; and observed 0.9). Nevertheless, there are some wells where the PCE trends do not match, such as wells MW-10C, MW-13B, and MW-14B. At two (MW-101C and MW-14B) of the three wells, observed concentrations in June 2000 exceeded those in December 1998. These increases may be the result of short-term variations in concentrations or long-term trends not adequately represented in the simulation.

Computed and observed decreases in PCE concentrations over time were analyzed to help assess model fit at the boundary between OU1 and OU2, a key area of the plume. Changes in PCE concentrations in this area are indicative of changes in rates of PCE mass entering OU2. PCE decreases were tabulated as a relative concentration, which is computed from the ratio of the concentration of PCE at time $x$ (referenced time) over the initial concentration of PCE in December 1998. As a gross measure of decreasing concentrations, the average decrease over time was computed from the average of the individual relative concentrations of these wells for each sampling date. The observed average relative concentration was computed from the individual relative concentrations of wells at the OU1/OU2 boundary-PW-13, PW-14, and MW-16 clusters. The computed average relative concentration was computed from the individual relative concentrations of model cells corresponding to these wells.

In general, decreases in model-computed PCE concentrations compare favorably with observed decreases at the OU1/ OU2 boundary. For May 2000, the average relative concentrations were 0.74 (computed) and 0.71 (observed). For September 1999, the average relative concentrations were 0.94 (computed) and 0.90 (observed). Therefore, the trends in computed and observed concentrations are being maintained over time.

The overall decrease in PCE concentrations at the OU1/ OU2 boundary, as measured at well clusters PW-13, PW-14, and MW-16, also was investigated by Harte and others (2001). The following exponential equation 10 (Harte and others, 2001, p. 44) described the decreases from remedial activities for observed PCE concentration as

$$
C / C_{o}=1.06 e^{0.43 t}
$$

where

and

$$
\begin{aligned}
& t=\text { years, } \\
& C=\text { observed current PCE concentration at } \\
& C_{o}=\text { observed initial }(\text { December 1998) } \mathrm{PCE}
\end{aligned}
$$


Table 10. Differences between model-computed tetrachloroethylene (PCE) concentrations and observed PCE concentrations for May 2000 in OU1, Savage Municipal Well Superfund Site, Milford, N.H.

[All concentrations are in parts per billion (ppb); negative difference means observed PCE greater than model-computed PCE; wells ranked by observed PCE concentration, May 2000; --, no data; C = PCE from May 2000; Co = PCE from December 1998. Well locations are shown on plate 2.]

\begin{tabular}{|c|c|c|c|c|c|c|c|c|c|c|c|}
\hline \multirow[b]{3}{*}{$\begin{array}{l}\text { Well } \\
\text { name }\end{array}$} & \multirow[b]{3}{*}{$\begin{array}{c}\text { Well } \\
\text { number }\end{array}$} & \multirow[b]{3}{*}{$\begin{array}{l}\text { Easting, State } \\
\text { Planar in feet }\end{array}$} & \multirow[b]{3}{*}{$\begin{array}{c}\text { Northing, State } \\
\text { Planar in feet }\end{array}$} & \multirow[b]{3}{*}{ Model layer } & \multicolumn{4}{|c|}{ Concentration of PCE } & \multirow{2}{*}{\multicolumn{3}{|c|}{$\begin{array}{c}\text { Relative PCE change in concentration } \\
\text { C/Co }\end{array}$}} \\
\hline & & & & & \multicolumn{2}{|c|}{ Observed } & \multirow{2}{*}{$\begin{array}{c}\begin{array}{c}\text { Model- } \\
\text { computed }\end{array} \\
\text { May } 2000\end{array}$} & \multirow[b]{2}{*}{$\begin{array}{l}\text { Difference for } \\
\text { May } 2000\end{array}$} & & & \\
\hline & & & & & December 1998 & May 2000 & & & $\begin{array}{c}\text { Model } \\
\text { computed }\end{array}$ & Observed & $\begin{array}{c}\text { Difference between model } \\
\text { computed and observed }\end{array}$ \\
\hline PW-3S & 536 & 975059.0 & 125239.0 & 2 & 2 & 2 & 35 & 33 & 0.57 & 1.00 & -0.43 \\
\hline B95-12 & 407 & 975343.8 & 124724.7 & 3 & 2 & 2 & 70 & 68 & 29.30 & 1.00 & 28.30 \\
\hline PW-3D & 537 & 975059.1 & 125239.1 & 5 & 2 & 2 & 50 & 48 & -- & 1.00 & -- \\
\hline PW-12S & 555 & 975432.0 & 125281.0 & 2 & 10 & 2 & 53 & 51 & 4.10 & .21 & 3.89 \\
\hline B95-15 & 409 & 975254.0 & 125149.4 & 5 & 410 & 12 & 399 & 387 & .53 & .03 & .50 \\
\hline PW2S & 532 & 975245.0 & 124965.0 & 2 & 1,400 & 27 & 738 & 711 & .51 & .02 & .49 \\
\hline MW-16A & 233 & 975671.2 & 124863.1 & 1 & 60 & 38 & 260 & 222 & 1.68 & .63 & 1.05 \\
\hline PW12M & 556 & 975437.2 & 125255.7 & 4 & 700 & 41 & 190 & 149 & .20 & .06 & .14 \\
\hline MW-16B & 321 & 975671.0 & 124868.6 & 3 & 310 & 51 & 384 & 333 & 2.35 & .16 & 2.19 \\
\hline PW-13M & 560 & 975682.1 & 125294.1 & 4 & 560 & 71 & 370 & 299 & .29 & .13 & .16 \\
\hline PW-13S & 559 & 975682.0 & 125294.0 & 2 & 94 & 89 & 124 & 35 & 10.78 & .95 & 9.83 \\
\hline B95-13 & 408 & 975490.6 & 125002.0 & 4 & 2,000 & 100 & 612 & 512 & .26 & .05 & .21 \\
\hline PW12D & 557 & 975432.2 & 125281.2 & 5 & 700 & 190 & 392 & 202 & .41 & .27 & .14 \\
\hline PW2M & 533 & 975245.1 & 124965.1 & 3 & 1,600 & 210 & 814 & 604 & .52 & .13 & .39 \\
\hline PW-14S & 562 & 975765.0 & 125085.0 & 2 & 950 & 230 & 640 & 410 & .69 & .24 & .45 \\
\hline PW-1D & 531 & 975507.1 & 125011.0 & 5 & 2,400 & 320 & 1,012 & 692 & .42 & .13 & .29 \\
\hline MW-16C & 344 & 975678.1 & 124877.1 & 4 & 1,500 & 380 & 525 & 145 & .50 & .25 & .24 \\
\hline MI-32 & 46 & 975247.2 & 124933.7 & 3 & 700 & 435 & 590 & 155 & .46 & .62 & -.16 \\
\hline PW-1S & 530 & 975498.5 & 125008.0 & 2 & 3,000 & 540 & 264 & -276 & .12 & .18 & -.06 \\
\hline PW-14M & 563 & 975765.1 & 125085.1 & 4 & 1,250 & 730 & 1,414 & 684 & .69 & .58 & .10 \\
\hline PW2D & 534 & 975245.2 & 124965.2 & 5 & 1,700 & 1,000 & 1,603 & 603 & .99 & .59 & .41 \\
\hline PW-13D & 561 & 975682.2 & 125294.2 & 5 & 1,100 & 1,100 & 874 & -226 & .67 & 1.00 & -.33 \\
\hline \multirow[t]{4}{*}{ PW-14D } & 564 & 975765.2 & 125085.2 & 5 & 1,750 & 2,700 & 2,107 & -593 & 1.02 & 1.54 & -.52 \\
\hline & & & & & & & $\begin{array}{r}\text { Standard } \\
\text { Mean Error }\end{array}$ & 228 & 2.6 & 0.5 & 2.1 \\
\hline & & & & & & & $\begin{array}{r}\text { Absolute } \\
\text { Mean Error }\end{array}$ & 323 & -- & -- & -- \\
\hline & & & & & & & Median & 202 & 0.5 & 0.3 & 0.3 \\
\hline
\end{tabular}


Table 11. Differences between model-computed tetrachloroethylene (PCE) concentrations and observed PCE concentrations for June 2000 in 0 2, Savage Municipal Well Superfund Site, Milford, N.H.

[All concentrations are in parts per billion (ppb); negative difference means observed PCE greater than model-computed PCE; wells ranked by observed PCE concentration, May 2000; --, no data; C = PCE from June 2000; Co = PCE from December 1998; u means non-detect. Well locations shown on plate 2.]

\begin{tabular}{|c|c|c|c|c|c|c|c|c|c|c|c|}
\hline \multirow[b]{3}{*}{ Well name } & \multirow[b]{3}{*}{$\begin{array}{c}\text { Well } \\
\text { number }\end{array}$} & \multirow[b]{3}{*}{$\begin{array}{l}\text { Easting, State } \\
\text { Planar in feet }\end{array}$} & \multirow[b]{3}{*}{$\begin{array}{c}\text { Northing, State } \\
\text { Planar in feet }\end{array}$} & \multirow[b]{3}{*}{ Model layer } & \multicolumn{4}{|c|}{ Concentration of PCE } & \multirow{2}{*}{\multicolumn{3}{|c|}{$\begin{array}{c}\text { Relative PCE change in concentration } \\
\text { C/Co }\end{array}$}} \\
\hline & & & & & \multicolumn{2}{|c|}{ Observed } & \multirow{2}{*}{\begin{tabular}{|c|} 
Model-computed \\
June 2000 \\
\end{tabular}} & \multirow[b]{2}{*}{$\begin{array}{l}\text { Difference for } \\
\text { June } 2000\end{array}$} & & & \\
\hline & & & & & December 1998 & June 2000 & & & $\begin{array}{c}\text { Model } \\
\text { computed }\end{array}$ & Observed & $\begin{array}{l}\text { Difference between model- } \\
\text { computed and observed }\end{array}$ \\
\hline MW32A & 296 & 981366.6 & 125490.0 & 1 & 1 & 0.4 & 0 & 0 & -- & -- & -- \\
\hline MI-4 & 165 & 978596.4 & 124892.5 & 3 & -- & .8 & 0 & -1 & -- & -- & -- \\
\hline MW34 & 281 & 979987.0 & 126490.7 & 1 & 2 & u1 & 8 & -- & -- & -- & -- \\
\hline MW22A & 293 & 981102.3 & 126204.0 & 2 & 3 & $\mathrm{u} 1$ & 7 & -- & -- & -- & -- \\
\hline MW22B & 294 & 981098.7 & 126201.3 & 3 & 2 & u1 & 0 & -- & -- & -- & -- \\
\hline MW32B & 297 & 981369.8 & 125487.1 & 2 & 1 & u1 & 0 & -- & -- & -- & -- \\
\hline FH-10 & & 975988.3 & 127199.9 & 3 & -- & u1 & 23 & -- & -- & -- & -- \\
\hline MW-19A & 326 & 977289.2 & 124123.2 & 2 & -- & u2 & 1 & -- & -- & -- & -- \\
\hline FH-14 & & 975867.0 & 126592.8 & 2 & -- & u2 & 23 & -- & -- & -- & -- \\
\hline MW-101A & 580 & 975981.9 & 125600.9 & 1 & 20 & 3 & 85 & 82 & 5.61 & 0.15 & 5.46 \\
\hline MI-11 & 24 & 979580.1 & 125310.7 & 3 & 4 & 6 & 13 & 7 & 5.32 & 1.50 & 3.82 \\
\hline MW20A & 264 & 977472.9 & 124629.1 & 2 & 11 & 8 & 53 & 45 & 4.62 & .73 & 3.90 \\
\hline MW-101B & 581 & 975984.5 & 125594.2 & 3 & 20 & 10 & 298 & 288 & 26.24 & .50 & 25.74 \\
\hline MW21C & 330 & 979001.5 & 124474.0 & 3 & 20 & 18 & 0 & -18 & -- & .90 & -- \\
\hline MW9C & 217 & 976503.3 & 124473.6 & 5 & 21 & 21 & 27 & 6 & .51 & 1.00 & -.49 \\
\hline MW11B & 319 & 976435.2 & 125885.3 & 3 & 41 & 29 & 486 & 457 & 13.24 & .71 & 12.54 \\
\hline MW9A & 351 & 976502.9 & 124485.8 & 2 & 50 & 30 & 12 & -18 & .54 & .60 & -.06 \\
\hline MW9B & 352 & 976503.6 & 124479.1 & 3 & 44 & 30 & 14 & -16 & .96 & .68 & .28 \\
\hline MW11A & 318 & 976433.3 & 125888.7 & 2 & 87 & 37 & 279 & 242 & 2.03 & .43 & 1.61 \\
\hline MW10A & 316 & 976221.5 & 124928.6 & 2 & 42 & 44 & 125 & 81 & 1.96 & 1.05 & .92 \\
\hline MW24A & 255 & 977644.9 & 126373.3 & 2 & 110 & 51 & 71 & 20 & .19 & .46 & -.27 \\
\hline MI-7 & 21 & 978642.4 & 125263.6 & 1 & 110 & 120 & 117 & -3 & 22.89 & 1.09 & 21.80 \\
\hline MW24B & 333 & 977649.7 & 126372.3 & 2 & 420 & 130 & 71 & -59 & .19 & .31 & -.12 \\
\hline FH-27 & 89 & 978957.5 & 126176.8 & 3 & 120 & 140 & 102 & -38 & .21 & 1.17 & -.95 \\
\hline MW10B & 317 & 976218.5 & 124928.4 & 3 & 82 & 140 & 172 & 32 & 1.67 & 1.71 & -.04 \\
\hline
\end{tabular}


Table 11. Differences between model-computed tetrachloroethylene (PCE) concentrations and observed PCE concentrations for June 2000 in 0 2, Savage Municipal Well Superfund Site, Milford, N.H.-Continued

[All concentrations are in parts per billion (ppb); negative difference means observed PCE greater than model-computed PCE; wells ranked by observed PCE concentration, May 2000; --, no data; C = PCE from June 2000; Co = PCE from December 1998; u means non-detect. Well locations shown on plate 2.]

\begin{tabular}{|c|c|c|c|c|c|c|c|c|c|c|c|}
\hline \multirow[b]{3}{*}{ Well name } & \multirow[b]{3}{*}{$\begin{array}{c}\text { Well } \\
\text { number }\end{array}$} & \multirow[b]{3}{*}{$\begin{array}{l}\text { Easting, State } \\
\text { Planar in feet }\end{array}$} & \multirow[b]{3}{*}{$\begin{array}{c}\text { Northing, State } \\
\text { Planar in feet }\end{array}$} & \multirow[b]{3}{*}{ Model layer } & \multicolumn{4}{|c|}{ Concentration of PCE } & \multirow{2}{*}{\multicolumn{3}{|c|}{$\begin{array}{c}\text { Relative PCE change in concentration } \\
\text { C/Co }\end{array}$}} \\
\hline & & & & & \multicolumn{2}{|c|}{ Observed } & \multirow{2}{*}{\begin{tabular}{|c|} 
Model-computed \\
June 2000
\end{tabular}} & \multirow[b]{2}{*}{$\begin{array}{l}\text { Difference for } \\
\text { June } 2000\end{array}$} & & & \\
\hline & & & & & December 1998 & June 2000 & & & $\begin{array}{c}\text { Model } \\
\text { computed }\end{array}$ & Observed & $\begin{array}{l}\text { Difference between model- } \\
\text { computed and observed }\end{array}$ \\
\hline MI-12 & 25 & 979476.4 & 125858.7 & 3 & 170 & 160 & 82 & -78 & 0.48 & 0.94 & -0.46 \\
\hline MI-8 & 22 & 976549.9 & 125251.5 & 1 & 280 & 180 & 359 & 179 & 1.25 & .64 & .61 \\
\hline MW14A & 349 & 978695.9 & 125654.9 & 2 & 495 & 410 & 292 & -118 & .72 & .83 & -.11 \\
\hline MW20B & 328 & 977476.1 & 124622.3 & 3 & 860 & 590 & 46 & -544 & .04 & .69 & -.65 \\
\hline MW14B & 341 & 978696.6 & 125651.1 & 3 & 500 & 630 & 404 & -226 & .75 & 1.26 & -.51 \\
\hline MW10C & 218 & 976215.0 & 124930.6 & 5 & 320 & 680 & 274 & -407 & .71 & 2.13 & -1.41 \\
\hline MW13B & 221 & 977300.6 & 125081.1 & 3 & 430 & 280 & 710 & 430 & 1.31 & 1.88 & -.57 \\
\hline MW13A & 308 & 977298.8 & 125084.8 & 2 & 850 & 810 & 500 & -310 & .47 & .95 & -.48 \\
\hline \multirow[t]{4}{*}{ MW-101C } & 582 & 975985.1 & 125588.7 & 5 & 970 & 1,300 & 755 & -546 & 1.41 & 1.34 & .07 \\
\hline & & & & & & & $\begin{array}{r}\text { Standard Mean } \\
\text { Error }\end{array}$ & -19 & 3.89 & 0.90 & 2.99 \\
\hline & & & & & & & $\begin{array}{r}\text { Absolute Mean } \\
\text { Error }\end{array}$ & 158 & -- & -- & -- \\
\hline & & & & & & & Median & -1 & 1.10 & 0.83 & 0.01 \\
\hline
\end{tabular}


Subsequent sampling rounds and additional PCE data from these same wells have yielded an updated rate constant of -0.26 . This revised-rate constant is approximately double that of the observed pre-remedial rate constant of -0.13 .

Computed decreases of PCE concentration from corresponding model cells at the OU1/OU2 boundary produced a similar rate constant. Exponential equation 11 describes decreases for model-computed PCE concentration as

$$
C m / C m_{o}=e^{-0.21 t}
$$

where

$$
\begin{aligned}
t & =\text { years, } \\
C m & =\text { model-computed current PCE concentra- } \\
& \text { tion at time } t
\end{aligned}
$$

and

$$
\begin{gathered}
C m_{o}=\text { model-computed initial }(\text { December 1998) } \\
\text { PCE concentration } .
\end{gathered}
$$

The similar rate constant values indicate comparable decreases in PCE concentrations are projected for computed and observed PCE concentrations. For example, the observed PCE trend at $t=10$ years is 0.08 of the initial concentration and the computed PCE trend is 0.12 .

\section{Enhancements to the Remedial Model}

Simulation results from the remedial period indicate that the model-computed PCE concentrations outside and near the eastern side of the barrier (downgradient of the valley-wide flow system) generally exceeded observed PCE concentrations. In contrast, PCE concentrations in the field show steep concentration gradients across the low-permeability barrier because of the containment of PCE mass, the slow transport of PCE across the barrier wall, and flushing of the PCE plume outside the barrier by relatively "clean" (low PCE concentration) water. Results of computed PCE solute transport across barriers in generalized hypothetical scenarios identified that MOC3D was overestimating dispersive transport across barriers (Konikow and others, 2001). A revision to the MOC3D code was written to more accurately simulate dispersive transport across low-permeability barriers when simulating low-permeability features with the HFB Package of MODFLOW. The revision, called the concentration with HFB Package (CHFB; Hornberger and others, 2002), allows for unique values of dispersivity, which are independent of aquifer dispersivities, to be assigned to the barrier itself.

An enhancement to the remedial model was done by incorporating use of the CHFB Package into the simulation of the remedial calibration period. A unique value of dispersivity was assigned to the barrier to improve the simulation of PCE solute transport across the barrier. A barrier dispersivity value of 0.1 of the aquifer dispersivity was used assuming that the hydraulic properties of the barrier are many orders of magnitude less than the MSGD aquifer. All other model parameters for the new simulation (run 101i, appendix 3) were kept similar to the calibrated model (model run 126, appendix 3).

PCE concentrations were recomputed using the enhanced remedial model (with use of the CHFB Package) and checked against OU1 observed PCE concentrations for September 1999 and May 2000. Model-computed concentrations are slightly less than the concentrations from the simulation without the use of the CHFB Package and indicate that the original model overestimated the dispersive transport of PCE across the barrier. The standard mean error for the enhanced model is $214 \mathrm{ppb}$ using computed and observed PCE concentrations for September 1999 at 17 OU1 wells outside the barrier (table 12). In comparison, the standard mean error was $232 \mathrm{ppb}$ for the original model (table 8). The largest improvement between simulations was for well B95-15, at which computed PCE concentration decreased from 496 to $421 \mathrm{ppb}$; compared to the observed PCE concentration of $82 \mathrm{ppb}$. For May 2000, the differences between simulations in computed PCE concentrations from wells affected by transport across the barrier are greater than for September 1999. At well B95-15, computed PCE concentrations for May 2000 at well B95-15 decreased from 399 ppb (without use of the CHFB Package, table 10) to $267 \mathrm{ppb}$ (with use of the CHFB Package, not shown in any table).

Model-computed decreases in PCE concentrations over time, corresponding to model cells for well clusters PW-13, PW-14, and MW-16 (fig. 3) at the OU1/OU2 boundary, decreased further with use of the CHFB Package. The revised rate constant that describes computed decreases at the OU1/ OU2 boundary is -0.23 with the use of CHFB and -0.21 (equation 11) without use of CHFB. The computed PCE decrease at $t=10$ years is 0.10 of the initial concentration with use of CHFB and 0.12 without use of CHFB. The observed decrease was 0.08 of the initial concentration. Because computed PCE concentrations at the OU1/OU2 boundary are affected by differences in transport across the barrier (as determined with the use of the CHFB Package in the enhanced model), simulated extraction of wells EW-1 and EW-2 (fig. 3) does not capture all of the PCE transport across the barrier.

The improved simulation of PCE mass transport across the barrier should improve long-term (greater than 5 years) predictions of aquifer remediation. Model computations beyond 5 years show a greater difference between simulations with the CHFB Package than without the CHFB Package (not shown in report).

During the $1 \frac{1}{2}$ years of remedial operations, PCE concentrations have decreased appreciably (50 percent) outside the barrier in OU1. Model-computed PCE concentrations for layer 3 (middle layer) for December 1998 and May 2000 are shown in figure 24. Concentrations exceeding 1,000 ppb outside the barrier in OU1 are limited to the area near the PW-14 cluster (fig. 24b), whereas concentrations are still above 2,000 ppb inside the barrier. 
Table 12. Differences between model-computed tetrachloroethylene (PCE) concentrations and observed PCE concentrations for September 1999 in OU1, Savage Municipal Well Superfund Site, Milford, N.H.

[All concentrations are in parts per billion (ppb); negative difference means observed PCE greater than model-computed PCE; wells ranked by observed PCE concentration, May 2000; --, no data; C = PCE from September 1999; Co = PCE from December 1998. Well locations shown on plate 2.]

\begin{tabular}{|c|c|c|c|c|c|c|c|c|c|c|c|c|}
\hline \multirow[b]{3}{*}{$\begin{array}{l}\text { Well } \\
\text { name }\end{array}$} & \multirow[b]{3}{*}{$\begin{array}{c}\text { Well } \\
\text { number }\end{array}$} & \multirow[b]{3}{*}{$\begin{array}{l}\text { Easting, } \\
\text { State Planar } \\
\text { in feet }\end{array}$} & \multirow[b]{3}{*}{$\begin{array}{l}\text { Northing, } \\
\text { State Planar } \\
\text { in feet }\end{array}$} & \multirow[b]{3}{*}{$\begin{array}{c}\text { Model } \\
\text { layer }\end{array}$} & \multicolumn{4}{|c|}{ Concentration of PCE } & \multicolumn{3}{|c|}{ Relative PCE change in concentration } & \multirow[b]{3}{*}{ Comments } \\
\hline & & & & & \multicolumn{2}{|c|}{ Observed } & \multirow{2}{*}{$\begin{array}{c}\begin{array}{c}\text { Model- } \\
\text { computed }\end{array} \\
\begin{array}{c}\text { September } \\
1999\end{array}\end{array}$} & \multirow[b]{2}{*}{$\begin{array}{c}\text { Difference } \\
\text { for } \\
\text { September } \\
1999\end{array}$} & \multicolumn{3}{|c|}{$\mathrm{C} / \mathrm{Co}_{0}$} & \\
\hline & & & & & $\begin{array}{c}\text { December } \\
1998\end{array}$ & $\begin{array}{c}\text { September } \\
1999\end{array}$ & & & $\begin{array}{c}\text { Model } \\
\text { computed }\end{array}$ & Observed & $\begin{array}{c}\text { Difference } \\
\text { between model- } \\
\text { computed and } \\
\text { observed }\end{array}$ & \\
\hline PW-12S & 555 & 975432.0 & 125281.0 & 2 & 10 & 21 & 37 & 16 & 2.82 & 2.10 & 0.72 & \multirow{5}{*}{$\begin{array}{l}\text { Observed PCE from } \\
\text { October } 1999 .\end{array}$} \\
\hline PW-13S & 559 & 975682.0 & 125294.0 & 2 & 94 & 41 & 103 & 62 & 8.67 & .44 & 8.24 & \\
\hline MW-16A & 233 & 975671.2 & 124863.1 & 1 & 60 & 58 & 354 & 296 & 2.27 & .99 & 1.28 & \\
\hline B95-15 & 409 & 975254.0 & 125149.4 & 5 & 410 & 82 & 421 & 339 & .55 & .20 & .35 & \\
\hline PW-13M & 560 & 975682.1 & 125294.1 & 4 & 560 & 120 & 647 & 527 & .50 & .21 & .29 & \\
\hline MW-16B & 321 & 975671.0 & 124868.6 & 3 & 310 & 320 & 410 & 90 & 2.48 & 1.03 & 1.45 & \multirow{5}{*}{$\begin{array}{l}\text { Observed PCE from } \\
\text { October } 1999 .\end{array}$} \\
\hline PW12D & 557 & 975432.2 & 125281.2 & 5 & 700 & 380 & 558 & 178 & .58 & .54 & .04 & \\
\hline PW12M & 556 & 975437.2 & 125255.7 & 4 & 700 & 410 & 239 & -171 & .25 & .58 & -.28 & \\
\hline PW2S & 532 & 975245.0 & 124965.0 & 2 & 1,400 & 530 & 1,105 & 575 & .76 & .38 & .38 & \\
\hline PW-14S & 562 & 975765.0 & 125085.0 & 2 & 950 & 640 & 1,010 & 370 & 1.09 & .67 & .42 & \\
\hline B95-13 & 408 & 975490.6 & 125002.0 & 4 & 2,000 & 690 & 1,261 & 571 & .53 & .35 & .18 & \\
\hline MW-16C & 344 & 975678.1 & 124877.1 & 4 & 1,500 & 860 & 692 & -168 & .65 & .57 & .08 & \\
\hline PW2M & 533 & 975245.1 & 124965.1 & 3 & 1,600 & 950 & 942 & -8 & .62 & .59 & .02 & \\
\hline PW2D & 534 & 975245.2 & 124965.2 & 5 & 1,700 & 1,000 & 1,617 & 617 & 1.00 & .59 & .41 & \\
\hline PW-14M & 563 & 975765.1 & 125085.1 & 4 & 1,250 & 1,100 & 1,964 & 864 & .95 & .88 & .07 & \\
\hline PW-13D & 561 & 975682.2 & 125294.2 & 5 & 1,100 & 1,000 & 1,058 & 58 & .82 & .91 & -.28 & $\begin{array}{l}\text { Observed PCE from } \\
\text { October } 1999 .\end{array}$ \\
\hline \multirow[t]{4}{*}{ PW-14D } & 564 & 975765.2 & 125085.2 & 5 & 1,750 & 2,700 & 2,114 & -586 & 1.02 & 1.54 & -.52 & \\
\hline & & & & & & & $\begin{array}{r}\text { Standard } \\
\text { Mean } \\
\text { Error }\end{array}$ & 214 & 1.50 & 0.74 & 0.76 & \\
\hline & & & & & & & $\begin{array}{r}\text { Absolute } \\
\text { Mean } \\
\text { Error }\end{array}$ & 324 & -- & -- & -- & \\
\hline & & & & & & & Median & 178 & 0.82 & 0.59 & 0.29 & \\
\hline
\end{tabular}


A.

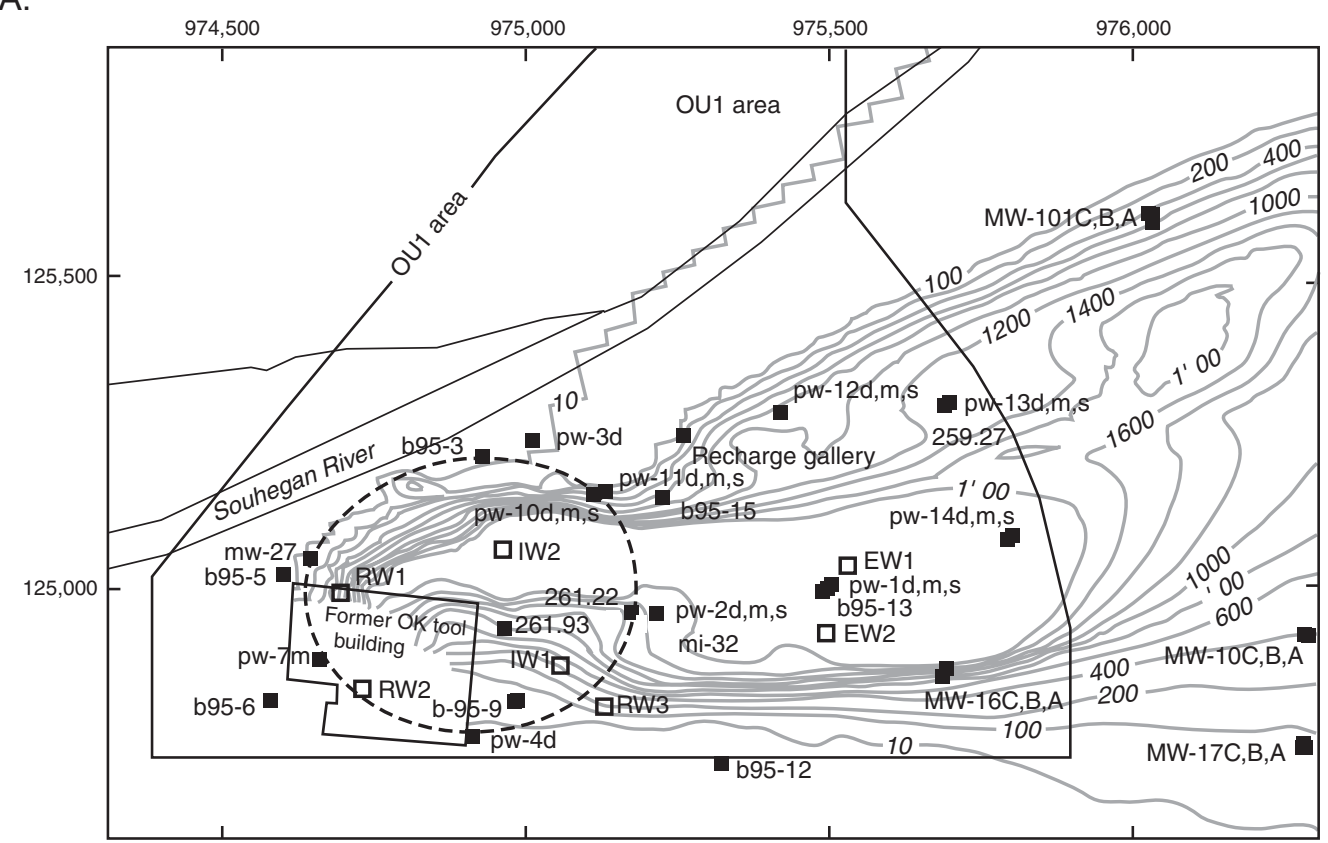

B.

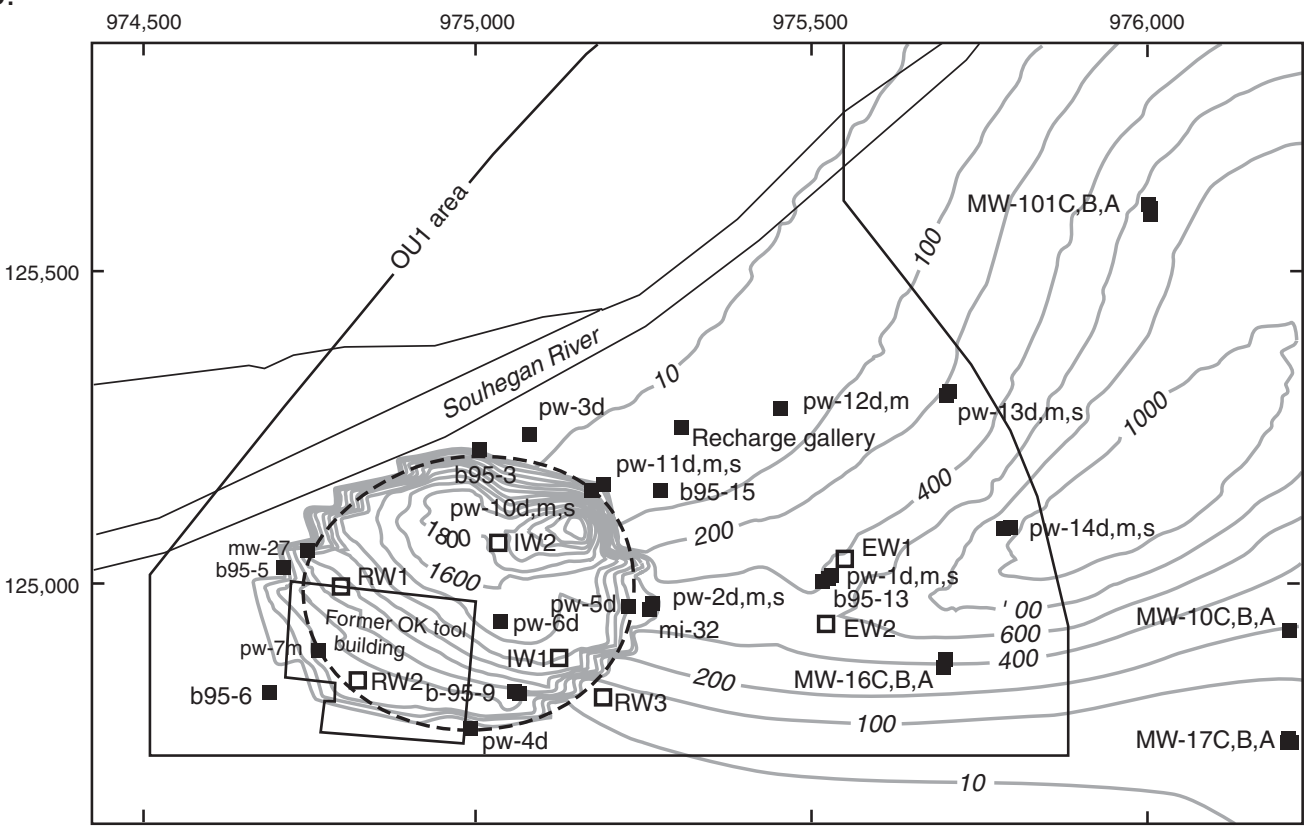

Base from U.S. Geological Survey digital raster graphics (DRG)

Milford, N.H. topographic quadrangle, 1:24,000-scale, 1968, photorevised 1985

New Hampshire state plane coordinate system

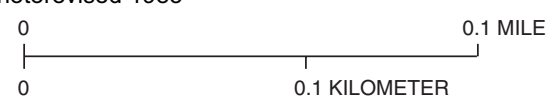

EXPLANATION
$-200-\quad \begin{gathered}\text { Contour of model-computed PCE concentration, in parts per billion. } \\ \text { Contour interval variable }\end{gathered}$
$\begin{gathered}\text { Barrier wall } \\ \text { EWW1 }\end{gathered}$
$\begin{aligned} & \text { Well name; letters denote multiple wells and relative depth } \\ & \text { (d or C, deep; } m \text { or B, medium; s or A, shallow) }\end{aligned}$

Figure 24. Model-computed tetrachloroethylene (PCE) concentrations for layer 3 for (A) December 1998, and for (B) May 2000 in the OU1 part of the Savage Municipal Well Superfund site, Milford, N.H. 


\section{Calibration of Final Solute-Transport Model}

The enhanced remedial model with use of the CHFB Package provides the best fit to observed field conditions. Trends in computed PCE concentrations generally match observed PCE concentrations; however, various deficiencies were noted and included a tendency of the model to vertically mix PCE concentrations to a greater extent than found in observed vertical distributions of PCE. This mixing indicates some reduction in vertical anisotropy or vertical dispersivity may be warranted.

Estimates of PCE mass along the southern edge of the plume of OU2 indicate that the starting mass was underestimated or that unknown sources of PCE exist. PCE solute transport along the northern edge of the plume in OU2 is overestimated. Observed PCE concentrations increased in the bedrock at this location, indicating some solute transport of PCE to the bedrock may occur that is not simulated in the model.

\section{Summary and Conclusions}

The U.S. Geological Survey (USGS), in cooperation with the New Hampshire Department of Environmental Services (NHDES) and the U.S. Environmental Protection Agency (USEPA), Region 1, is studying the solute transport of volatile organic compounds (VOCs), specifically tetracholoroethylene (PCE), in contaminated ground waters of the unconsolidated sediments at the Savage Municipal Well Superfund site (Savage site). The Savage site, named after the former municipal watersupply well for the town of Milford, is underlain by a large $0.5-\mathrm{mi}^{2}$ plume of VOCs. The plume is logistically divided into two areas called Operable Unit No. 1 (OU1), which contains the primary source area, and Operable Unit No. 2 (OU2), which is defined as the extended plume area.

Two-dimensional and three-dimensional finite-difference solute-transport models of the unconsolidated sediments were constructed to help evaluate solute-transport processes, assess the effectiveness of remedial activities in OU1, and to help design remedial strategies for OU2. The solute-transport models simulate PCE concentrations and model results were compared to observed concentrations of PCE. Simulations included historical calibrations of the distribution of PCE from its initial input (circa 1960) into the subsurface until the 1990s, a preremedial calibration from 1995-98, and a remedial (post-barrier wall) calibration from 1998-99. Model results also were checked against observed PCE concentrations from May and June 2000.

The VOC plume at the Savage site is dominated by advective transport because of the relatively high hydraulic conductivity of the Milford-Souhegan glacial-drift (MSGD) aquifer. The MSGD aquifer contains an upper cobble zone in OU1, sand and gravel units, some fine sands, and a basal till layer. The plume also extends into the underlying bedrock. The primary VOC is PCE. Secondary VOCs include tricholoroethylene (TCE) and cis-1,2-dichloroethylene (cis-1,2-DCE); both compounds are present at about 0.1 to 0.001 of the concentration of
PCE. TCE and cis-1,2-DCE also can be degradation products of PCE. Because of a lack of electron donors, namely carbon, degradation of PCE appears to be spatially limited and at low rates (degradation half lives greater than 10 years). Therefore, appreciable downgradient increases in TCE and cis-1,2-DCE, relative to PCE, have not been observed. The estimated dissolved mass of PCE has decreased from approximately $3.0 \mathrm{Mg}$ in 1989 to $2.2 \mathrm{Mg}$ in 1995 and $1.2 \mathrm{Mg}$ in 1998 . The cause of the decrease in the dissolved PCE mass is believed to be a decrease in mass input from a Dense Non-Aqueous Phase Liquid (DNAPL) source, because PCE concentration decreases observed at wells near the source were similar to decreases at wells farther removed.

In the fall of 1998, a remedial system was installed by NHDES and USEPA at the site of a former tool manufacturing facility (the OK Tool facility). This part of the Savage site, called OU1, had PCE concentrations in excess of 100,000 ppb in 1995, indicating a likely DNAPL source. The OU1 remedial system includes a low-permeability barrier wall that encircles the highest concentrations of PCE, and a series of injection and extraction wells. The barrier primarily sits atop bedrock and penetrates the full thickness of the sand and gravel, and, in some places, the full thickness of the underlying basal till.

A numerical solute-transport-model code called MOC3D was used to simulate solute transport of PCE. The solute-transport model solves the three-dimensional solute-transport equation by use of the method of characteristics and is integrated with MODFLOW, which is used to generate ground-water velocity fields. The three-dimensional solute-transport equation describes the change in concentration of solute over time as a function of advection, dispersion, retardation, sources, and irreversible reaction. Simulated transport parameters included contaminant mass input (for the historical calibration period only), dispersivity, retardation (linear), and irreversible reaction rate (exponential decay). A previously published ground-waterflow model of the plume area was used as input to the solutetransport model.

The historical calibration (1960-94) used a simplified twodimensional model to simulate the evolution of the distribution of PCE. PCE mass input was simulated by specifying a dissolved input of PCE at model cells near suspected DNAPL locations in OU1. Results of this calibration indicate that the modelcomputed length of the plume is controlled by the model-retardation parameter. Values of retardation greater than 3 caused the longitudinal length of the computed plume to be too short compared to the observed plume. PCE transport rates of about $0.5 \mathrm{ft} / \mathrm{d}$ were required to reproduce the observed plume length (about $1 \mathrm{mi}$ ). A retardation of 2 produced a reasonable comparison between computed and observed PCE concentrations. Testing of different initial PCE input times showed little difference between starting in 1950 (the earliest potential start of PCE contamination in the aquifer) and starting in 1960. In either case, the plume reaches a quasi steady-state distribution in about 20 years. Although not simulated in the pre-remedial and remedial calibration periods, mass input of PCE was estimated at a rate of $1 \mathrm{~g} / \mathrm{min}$ from a DNAPL source in the OU1 area. 
The pre-remedial calibration period (1995-98) used a three-dimensional model and focused on calibrating to observed PCE concentrations at wells in OU2. The model is vertically discretized into five model layers to represent stratigraphic trends in the MSGD aquifer. A starting dissolved PCE mass of $2.06 \mathrm{Mg}$ (4.57 Mg total (sorbed and dissolved mass)) was specified. No additional mass input of PCE was specified. The model also was calibrated for advective transport by comparing computed advective ground-water ages to apparent ages of water samples collected from wells in the OU1 area. Sample water ages were determined by analyses of tritium-helium concentrations. A decrease in horizontal and vertical hydraulic conductivity in model layer 2 (shallow aquifer) helped reduce differences and improve model fit between computed groundwater ages and apparent ground-water ages from tritium-helium concentrations.

Model results from the final pre-remedial calibration had a residual standard mean error of $27 \mathrm{ppb}$ from 46 wells distributed throughout OU2 and screened in each of the five model layers. Spatial biases were observed. The computed PCE concentrations were greater than observed PCE concentrations along the northern part of the plume. PCE concentration increases in a bedrock well along the northern flank indicate that some PCE transport to the north may be entering the bedrock, which is not simulated in the model. In contrast, computed PCE concentrations were less than observed concentrations along the southern part of the plume. This difference is likely the result of an underestimation of the initial PCE mass in this area or an unaccounted source of PCE because testing of high retardation values did little to reduce residuals. Differences also could be caused by small inaccuracies in the simulated flowpaths because large-concentration gradients occur along the southern part of the plume. The computed rate of PCE mass decrease for OU1 and OU2 is about $0.32 \mathrm{Mg} / \mathrm{yr}$ under pre-remedial conditions. Most of this decrease is attained through discharge of PCE solute to the Souhegan River.

The remedial calibration period (1998-99) used a threedimensional model that focused on observed PCE concentrations in wells in OU1. The initial starting mass of dissolved PCE was $1.2 \mathrm{Mg}$. No additional mass input was specified. An additional goal of the remedial calibration was to reproduce groundwater-head (water-level) patterns caused by the addition of the barrier wall in OU1 and operation of remedial wells, and to reproduce PCE concentrations in the exterior barrier area of OU1. The addition of the barrier wall and operation of remedial wells caused flow patterns in OU1 to change. Furthermore, the flow system was highly affected by transient processes (variations in temporal rates of recharge) in the aquifer in OU1.

An objective of the remedial operation in OU1 is to maintain inward hydraulic head gradients across the barrier so as to prevent outward migration of PCE. Variations in rates of recharge, however, caused observed head gradients over the short term (days) to change from inward to outward across the barrier even though remedial wells were operating. In general, the model-computed heads reproduced observed heads except for September 1999, when the computed heads inside the barrier did not rise sufficiently to cause an outward head gradient, as observed in the field. The inadequacy of the model to reproduce this observed pattern may be caused by a too coarse numerical time discretization or an underestimation of recharge inside the barrier.

Model-computed PCE concentrations for the remedial calibration generally were higher than observed. The standard mean error, computed for September 1999 using 17 wells in OU1 outside the barrier wall, was $232 \mathrm{ppb}$, indicating a positive residual bias. September 1999 was 9 months after the barrier wall was installed and 4 months after the start-up of remedial wells. Computed concentrations near the barrier did not reproduce the steep concentration gradient (high PCE concentrations inside the barrier and low PCE concentrations outside the barrier) observed in the field. A post audit of model performance compared computed and observed PCE concentrations for May 2000. Results indicated that residuals increased near the barrier. Application of an enhancement to the numerical model called the Concentration with the Horizontal-Flow Barrier (CHFB) Package, however, resulted in computed concentration gradients that were steeper than those computed without the use of the CHFB Package. The steep observed concentration gradients are an excellent indicator that the barrier is preventing outward transport of PCE.

The overall decrease of PCE concentrations at the OU1/ OU2 boundary, as measured at wells at the downgradient edge of OU1, were compared to computed decreases to evaluate the capacity of the model to reproduce observed trends in an important area of the plume. A first-order exponential equation was fit to the observed and computed trends in PCE. The observed exponential rate constant was -0.26 and the computed rate constant was -0.23 . Results indicate that model-computed decreases in PCE concentration were comparable to the observed.

The rate of computed PCE mass decrease for OU1 and OU2 is about $0.50 \mathrm{Mg} / \mathrm{yr}$ under remedial conditions. This rate is approximately twice that of the pre-remedial conditions. The remedial wells in OU1 account for about a half of the total PCE mass decrease per year as of 1999-2000, and discharge of PCE solute to the Souhegan River accounts for the other half.

The final solute-transport parameters used in the model contained a retardation factor of 2 for model layers 1, 3, and 5; and 2.5 for layers 2 and 4 that contain some fine sand layers. Dispersivity was set at $54 \mathrm{ft}$ in the longitudinal and $12 \mathrm{ft}$ in the transverse. A vertical dispersivity of $1.2 \mathrm{ft}$ was used; however, this rate could be lowered and may help with further calibration efforts. Volatilization was simulated in the model for remedial conditions at an exponential decay rate of $6.0 \mathrm{e}^{-12}$ per year.

\section{Acknowledgments}

The author wishes to thank Thomas Andrews of the New Hampshire Department of Environmental Services (NHDES), Richard Goehlert, site remedial project manager of the U.S. Environmental Protection Agency (USEPA), Region 1, and Richard Willey, lead hydrogeologist, USEPA, Region 1, for their cooperation and support. Because of the collaborative nature of the study, the author also wishes to thank the private companies and individuals who work at the Superfund site for their cooperation. 


\section{Selected References}

Brayton, M.J., and Harte, P.T., 2001, Results of a monitoring program of continuous water levels, specific conductance, and water temperature at the OK Tool facility of the Savage Municipal Well Superfund site, Milford, New Hampshire: U.S. Geological Survey Open-File Report 01-338, 50 p.

Buscheck, T.E., and Alcantar, C.M., 1995, Regression techniques and analytical solutes to demonstrate intrinsic bioremediation, in Proceedings of the 1995 Battele International Conference on in-situ and on site bioreclamation, April 1995.

Camp, Dresser, and McKee, Federal Programs Corporation, 1995, Final report of vertical contaminant profiling, Savage Municipal Supply Well, Superfund site-OU1, Milford, New Hampshire: Boston, Mass., Camp, Dresser, and McKee, Inc., Federal Programs Corporation, November 1995, 5 chaps., 5 apps.

Camp, Dresser, and McKee, Inc., 1996, Conceptual remedial design report for OK tool source area, Savage Municipal Supply Well, Superfund site-OU1, Milford, New Hampshire: Cambridge, Mass., Camp, Dresser, and McKee, Inc., March 1996, v. 1, 5 chaps.

Chapelle, F.H., 1993, Ground-water microbiology and geochemistry: John Wiley and Sons, Inc., N.Y., 424 p.

Chiou, C.T., Peters, L.J., and Freed, V.H., 1979, A physical concept of soil-water equilibria for nonionic organic compounds: Science, v. 206, p. 831-832.

Coakley, M.F., Keirstead, Chandlee, Brown, R.O., and Hilgendorf, G.S., 1997, Water Resources Data New Hampshire and Vermont Water Year 1996: U.S. Geological Survey Water-Data Report NH-VT-96-1, 189 p.

Cohen, R.M., and Mercer, J.W., 1993, DNAPL Site Evaluation: Boca Raton, Fla., CRC Press, Inc., variously paginated.

Ellis, D.E., 1996, Remediation technology development forum intrinsic remediation project at Dover Air Force Base, Delaware, in Symposium on natural attenuation of chlorinated organics in groundwater: U.S. Environmental Protection Agency 540/R-96/509, p. 95-99.

Environmental Science and Engineering, Inc., 1995, Results of vertical profiling program Savage Municipal Supply Well Superfund site: Amherst, N.H., Environmental Science and Engineering, Inc., 3 chaps.

Environmental Science and Engineering, Inc., 1997, Final results of vertical profiling program Savage Municipal Supply Well Superfund site: Amherst, N.H., Environmental Science and Engineering, Inc., February 1997, 25 p.

Environmental Systems Research Institute, Inc. (ESRI), 1994, Network analysis: Redlands, Calif., 208 p.

Freeze, R.A., and Cherry, J.A., 1979, Groundwater: Englewood Cliffs, N.J., Prentice-Hall, 604 p.

Gelhar, L.W., Montogluo, A., Welty, C., Rehfeldt, K.E., 1985, A review of field-scale physical solute-transport processes in saturated and unsaturated porous media: Electric Power Research Institute Report no. EA-4190.
Gelhar, L.W., Welty, Claire, and Rehfeldt, K.R., 1992, A critical review of data on field-scale dispersion in aquifers: Water-Resources Research, v. 28, no. 7, p. 1995-1974.

Goode, D.J., and Konikow, L.F., 1990, Apparent dispersion in transient groundwater flow: Water Resources Research, v. 26, no. 10, p. 2339-2351.

Harbaugh, A.W., and McDonald, M.G., 1996a, User's documentation for MODFLOW-96, an update to the U.S. Geological Survey modular finite-difference ground-water flow model: U.S. Geological Survey Open-File Report 96-485, $56 \mathrm{p}$.

Harbaugh, A.W., and McDonald, M.G., 1996b, Programmer's documentation for MODFLOW-96, an update to the U.S. Geological Survey modular finite-difference ground-water flow model: U.S. Geological Survey Open-File Report 96486, 220 p.

Harbaugh, A.W., Banta, E.R., Hill, M.C., and McDonald, M.G., 2000, MODFLOW-2000, The U.S. Geological Survey modular ground-water model-User guide to modularization concepts and the ground-water flow process: U.S. Geological Survey Open-File Report 00-92, 121 p.

Harte, P.T., Brayton, M.J., Ives, Wayne, Perkins, Sharon, and Brown, Carroll, 2001, Testing and application of water-diffusion samplers to identify temporal trends in volatile-organic compounds: U.S. Geological Survey Open-File Report 00196, $91 \mathrm{p}$.

Harte, P.T., Flynn, R.J., and Mack, T.J., 1999, Construction and calibration of numerical ground-water flow models of the Milford-Souhegan glacial-drift aquifer, Milford, New Hampshire: U.S. Geological Survey Open-File Report 99-462, $76 \mathrm{p}$.

Harte, P.T., Flynn, R.J., Kiah, R.G., Severance, Timothy, Coakley, M.F., 1997, Information on hydrologic and physical properties of water to assess transient hydrology of the Milford-Souhegan glacial-drift aquifer, Milford, New Hampshire: U.S. Geological Survey Open-File Report 97-414, $96 \mathrm{p}$.

Harte, P.T., and Mack, T.J., 1992, Geohydrology of, and simulation of, ground-water flow in the Milford-Souhegan glacial-drift aquifer, Milford, New Hampshire: U.S. Geological Survey Water-Resources Investigations Report 91-4177, $90 \mathrm{p}$.

Harte, P.T., and Willey, R.E., 1997, Effects of historical withdrawals on advective transport of contaminated ground waters in a glacial-drift aquifer, Milford, New Hampshire: U.S. Geological Survey Fact Sheet FS 162-97, 6 p.

Heberton, C.I., Russell, T.F., Konikow, L.F., and Hornberger, G.Z., 2000, A three-dimensional finite-volume eulerianlagrangian localized adjoint method (ellam) for solute-transport modeling: U.S. Geological Survey Water-Resources Investigations Report 00-4087, 63 p.

Hill, M.C., 1990, Preconditioned-Conjugate-Gradient 2 (PCG2), a computer program for solving ground-water flow equations: U.S. Geological Survey Water-Resources Investigations Report 90-4048, 43 p. 
Hornberger, G.Z., Konikow, L.F., and Harte, P.T., 2002, Simulating solute transport across horizontal-flow barriers using the MODFLOW Ground-Water Transport Process: U.S. Geological Survey Open-File Report 02-52, 28 p.

HMM Associates, Inc., 1989, Draft remedial investigation, Savage well site, Milford, New Hampshire: Concord, Mass., no. $2176 \mathrm{HAZ} / 2880,218 \mathrm{p}$.

HMM Associates, Inc., 1991, Remedial investigation, Savage well site, Milford, New Hampshire: Concord, Mass., no. $2176 \mathrm{HAZ} / 4814,800 \mathrm{p}$.

Imbrigiotta, T.E., and Ehlke, T.A., 1999, Relative importance of natural attenuation processes in a trichloroethene plume and comparison to pump-and-treat remediation at Picatinny Arsenal, New Jersey, in Morganwalp, D.W., and Buxton, H.T., eds., U.S. Geological Survey Toxic Substances Hydrology Program-Proceedings of the technical meeting, Charleston, S.C., March 8-12, 1999: U.S. Geological Survey Water-Resources Investigations Report 99-4018C, p. 615624.

Imbrigiotta, T.E., and Martin, Mary, 1996, Overview of research activities on the transport and fate of chlorinated solvents in ground water at Picatinny Arsenal, New Jersey, 1991-93, in Morganwalp, D.W., and Aronson, D.A., eds. U.S. Geological Survey Toxic Substances Hydrology Program-Proceedings of the Technical Meeting, Colorado Springs, Colo., September 20-24, 1993: p. 290-305.

Kipp, K.L., Jr., Konikow, L.F., and Hornberger, G.Z., 1998, An implicit dispersive transport algorithm for the U.S. Geological Survey MOC3D solute-transport model: U.S. Geological Survey Water-Resources Investigations Report 98-4234, $54 \mathrm{p}$.

Konikow, L.F., Goode, D.J., and Honberger, G.Z., 1996, A three-dimensional method of characteristics solute-transport model (MOC3D): U.S. Geological Survey Water-Resources Investigations Report 96-4267, 87 p.

Konikow, L.F., Harte, P.T., and Honberger, G.Z., 2001, Simulating solute transport across horizontal-flow barriers in MODFLOW 2001 and Other Modeling Odysseys, September 11-14, 2001, Golden, Colo., Proceedings: v. 2, p. 510516.

Koteff, Carl, 1970, Surficial geologic map of the Milford quadrangle, Hillsborough County, New Hampshire: U.S. Geological Survey Geologic Quadrangle Map GQ-881, scale $1: 62,500$.

Lorah, M.M., Olsen, L.D., Smith, B.L., Johnson, M.A., and Fleck, W.B., 1997, Natural attenuation of chlorinated volatile organic compounds in a freshwater tidal wetland, Aberdeen Proving Ground, Maryland: U.S. Geological Survey WaterResources Investigations Report 97-4171, 95 p.

Lyons, J.B., Bothner, W.A., Moench, R.H., and Thompson, J.B., 1997, Bedrock geologic map of New Hampshire: U.S. Geological Survey State Geologic Map, 2 sheets, scale $1: 250,000$ and 1:500,000.
Mabey, W.R., Smith, J.H., Podoll, R.T., Johnson, H.L., Mill, T., Chou, T.W., Gates, J., Partridge, I.W., Jaber, H., and Vandenberg, D., 1982, Aquatic fate process data for organic priority pollutants: U.S. Environmental Protection Agency, EPA 440/4-81-014, 434 p.

McCarty, P.L., 1994, An overview of anaerobic transformation of chlorinated solvents, in Proceedings of the symposium on natural attenuation of groundwater: U.S. Environmental Protection Agency 600/R-94/162, p. 116-119.

McDonald, M.G., and Harbaugh, A.W., 1988, A modular threedimensional finite-difference ground-water flow model: U.S. Geological Survey Techniques of Water-Resources Investigations, book 6, chap. A1, $586 \mathrm{p}$.

McDonald, M.G., Harbaugh, A.W., Orr, B.R., and Ackerman, D.J., 1991, A method of converting no-flow cells to variablehead cells for the U.S. Geological Survey modular finite-difference ground-water flow model: U.S. Geological Survey Open-File Report 91-536, 95 p.

Pollock, D.W., 1994, User's guide for MODPATH/MODPATH-PLOT, Version 3: A particle tracking post-processing package for MODFLOW the U.S. Geological Survey finite-difference ground-water flow model: U.S. Geological Survey Open-File Report 94-464, 220 p.

QST Environmental, Inc., 1997, Draft remedial design investigation report: Nashua, N.H., variously paginated.

Weaver, J.W., Wilson, J.T., and Kampbell, D.H., 1997, Extraction of degradation rate constants from the St. Joseph, Michigan, in Proceedings of the symposium on natural attenuation of chlorinated organics in ground water: U.S. Environmental Protection Agency 540/R-97/504, p. 71-75.

Wilson, J.T., Kampbell, D.H., and Weaver, J.W., 1996, Environmental chemistry and the kinectics of biotransformation of chlorinated organic compounds in groundwater, in Proceedings of the symposium on natural attenuation of chlorinated organics in groundwater: U.S. Environmental Protection Agency 540/R-96/509, p. 133-136.

Wilson, J.T., Weaver, J.W., and Kampbell, D.H., 1994, Intrinsic bioremediation of TCE in ground water at an NPL site in St. Joseph, Michigan, in Proceedings of the symposium on natural attenuation of groundwater: U.S. Environmental Protection Agency 600/R-94/162, p. 116-119.

Winston, R.B., 2000, Graphical user interface for MODFLOW, Version 4: U.S. Geological Survey Open-File Report 00$315,27 \mathrm{p}$.

Saleem, Z.A., 1999, Anaerobic biodegradation rates of organic chemicals in groundwater: A summary of field and laboratory studies: U.S. Environmental Protection Agency Draft, table 2-1.

Schlosser, P., Stute, M., Dorr, H., Sonntag C., and Munnich, K.O., 1988, Tritium/3He dating of shallow groundwater: Earth and Planetary Science Letters, v. 89, p. 353-362.

Zheng, Chunmiao, and Bennett, G.D., 1995, Applied contaminant transport modeling: New York, Van Nostrand Reinhold, $440 \mathrm{p}$. 



\section{Appendix 1}

Information on wells and vertical profile points, Savage Municipal Well Superfund site, Milford, N.H. 
Appendix 1. Information on wells and vertical profile points, Savage Municipal Well Superfund site, Milford, N.H.

[All units in feet; horizontal datum based on 2,000-foot grid New Hampshire State Planar coordinate system North American Datum 1983; vertical datum based on feet above NGVD 1929; depth in feet below land surface; well name descriptions on page ix; some wells not shown on plate 1; -- no data; wells sorted by easting location; Description of measurement point: TSC = top of steel casing; TPVC = top of polyvinyl chloride pipe; shelter = top of shelter floor; SG = staff gage; SG2 = second staff gage; SG3 = third staff gage; SG4 = fourth staff gage; TCONC = top of concrete; RIM = rim of manhole cover; BOLT HEAD = top of bolt; WELLCVR = well cover; TINRSC = top of inner steel casing; AHPUMP = air line reading at pump; top rebar = top of rebar pipe; usgs disc = top of usgs disc; VENT = vent hole at pump]

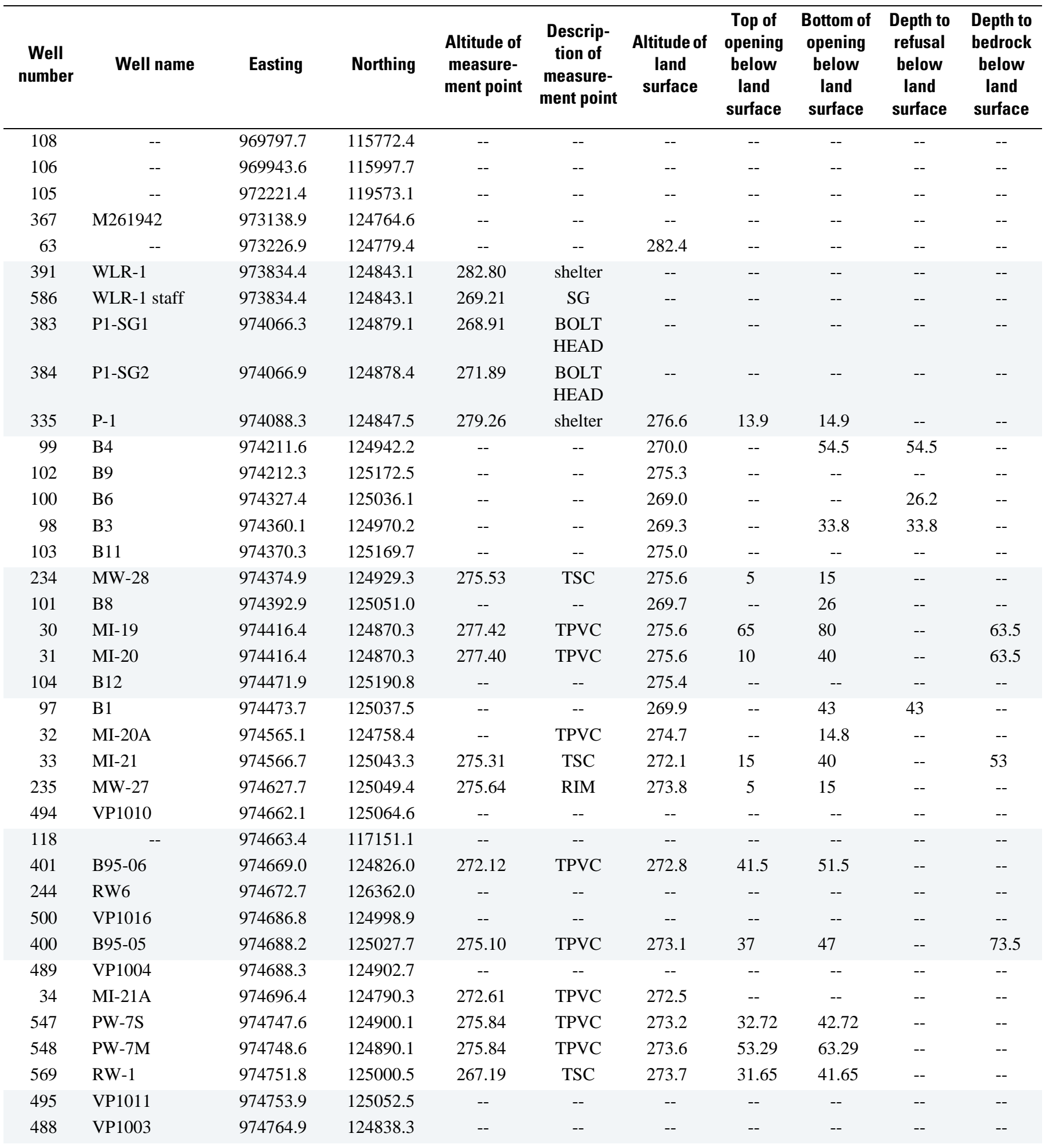


Appendix 1. Information on wells and vertical profile points, Savage Municipal Well Superfund site, Milford, N.H.—Continued

[All units in feet; horizontal datum based on 2,000-foot grid New Hampshire State Planar coordinate system North American Datum 1983; vertical datum based on feet above NGVD 1929; depth in feet below land surface; well name descriptions on page ix; some wells not shown on plate 1; -- no data; wells sorted by easting location; Description of measurement point: $\mathrm{TSC}=$ top of steel casing; $\mathrm{TPVC}=$ top of polyvinyl chloride pipe; shelter $=$ top of shelter floor; $\mathrm{SG}=$ staff gage; SG2 = second staff gage; SG3 = third staff gage; SG4 = fourth staff gage; TCONC = top of concrete; RIM = rim of manhole cover; BOLT HEAD = top of bolt; WELLCVR = well cover; TINRSC $=$ top of inner steel casing; AHPUMP = air line reading at pump; top rebar $=$ top of rebar pipe; usgs disc $=$ top of usgs disc; VENT $=$ vent hole at pump]

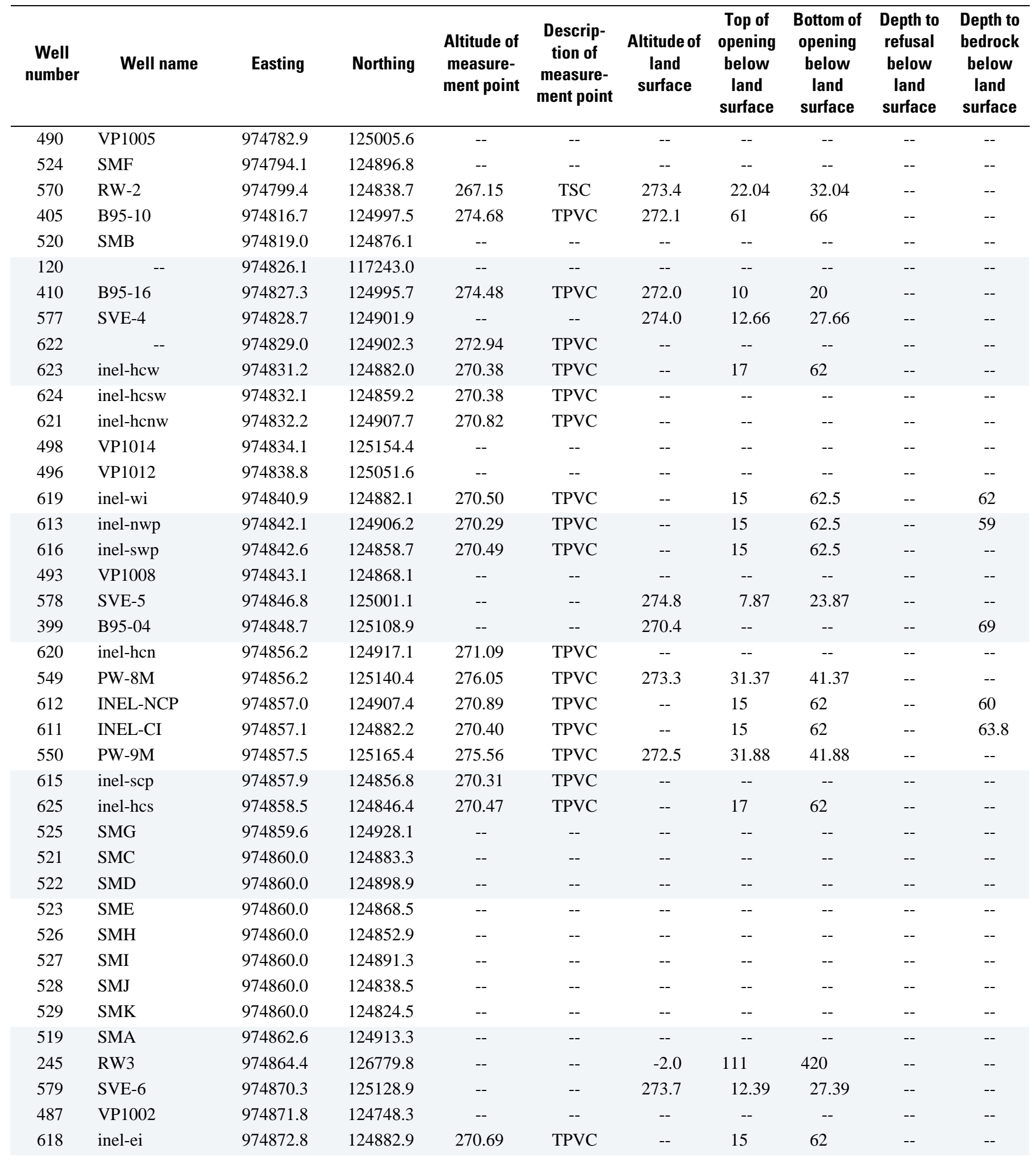


Appendix 1. Information on wells and vertical profile points, Savage Municipal Well Superfund site, Milford, N.H.-Continued

[All units in feet; horizontal datum based on 2,000-foot grid New Hampshire State Planar coordinate system North American Datum 1983; vertical datum based on feet above NGVD 1929; depth in feet below land surface; well name descriptions on page ix; some wells not shown on plate 1; -- no data; wells sorted by easting location; Description of measurement point: $\mathrm{TSC}=$ top of steel casing; $\mathrm{TPVC}=$ top of polyvinyl chloride pipe; shelter $=$ top of shelter floor; $\mathrm{SG}=$ staff gage; SG2 = second staff gage; SG3 = third staff gage; SG4 = fourth staff gage; TCONC = top of concrete; RIM = rim of manhole cover; BOLT HEAD = top of bolt; WELLCVR = well cover; TINRSC $=$ top of inner steel casing; AHPUMP = air line reading at pump; top rebar = top of rebar pipe; usgs disc $=$ top of usgs disc; VENT $=$ vent hole at pump]

\begin{tabular}{|c|c|c|c|c|c|c|c|c|c|c|}
\hline $\begin{array}{c}\text { Well } \\
\text { number }\end{array}$ & Well name & Easting & Northing & $\begin{array}{l}\text { Altitude of } \\
\text { measure- } \\
\text { ment point }\end{array}$ & $\begin{array}{l}\text { Descrip- } \\
\text { tion of } \\
\text { measure- } \\
\text { ment point }\end{array}$ & $\begin{array}{c}\text { Altitude of } \\
\text { land } \\
\text { surface }\end{array}$ & $\begin{array}{c}\text { Top of } \\
\text { opening } \\
\text { below } \\
\text { land } \\
\text { surface }\end{array}$ & $\begin{array}{l}\text { Bottom of } \\
\text { opening } \\
\text { below } \\
\text { land } \\
\text { surface }\end{array}$ & $\begin{array}{l}\text { Depth to } \\
\text { refusal } \\
\text { below } \\
\text { land } \\
\text { surface }\end{array}$ & $\begin{array}{c}\text { Depth to } \\
\text { bedrock } \\
\text { below } \\
\text { land } \\
\text { surface }\end{array}$ \\
\hline 614 & inel-nep & 974873.1 & 124906.4 & 271.16 & TPVC & -- & 15 & 62.5 & -- & 59 \\
\hline 617 & inel-sep & 974873.6 & 124858.0 & 270.78 & TPVC & -- & -- & -- & -- & -- \\
\hline 626 & inel-hcse & 974883.5 & 124858.0 & 270.31 & TPVC & -- & -- & -- & -- & -- \\
\hline 572 & SP-1 & 974885.1 & 124935.8 & 266.58 & TSC & 274.5 & 60.66 & 65.66 & -- & 66.8 \\
\hline 50 & MI-36 & 974900.8 & 123429.2 & 270.51 & TPVC & 269.9 & -- & 12.5 & -- & -- \\
\hline 573 & SP-2 & 974910.9 & 125063.9 & 266.57 & TSC & 275.3 & 59.71 & 64.71 & -- & -- \\
\hline 491 & VP1006 & 974922.8 & 124990.3 & -- & -- & -- & -- & -- & -- & -- \\
\hline 309 & MW-1B & 974926.7 & 122718.3 & 281.38 & TPVC & 279.5 & 35.4 & 45.4 & -- & -- \\
\hline 574 & SVE-1 & 974927.1 & 124888.1 & -- & -- & 275.0 & 8.37 & 23.36 & -- & -- \\
\hline 307 & MW-1A & 974929.8 & 122712.2 & 281.26 & TPVC & 279.7 & 5 & 17 & -- & -- \\
\hline 575 & SVE-2 & 974946.5 & 124988.0 & -- & -- & 276.3 & 9.41 & 24.41 & -- & -- \\
\hline 497 & VP1013 & 974958.5 & 125128.4 & -- & -- & -- & -- & -- & -- & -- \\
\hline 43 & MI-28 & 974962.8 & 124603.6 & 271.85 & TPVC & 270.3 & 35 & 55 & 56 & -- \\
\hline 539 & PW-4D & 974963.8 & 124756.7 & 274.49 & TOC & 272.0 & 62 & 72 & -- & 70 \\
\hline 576 & SVE-3 & 974966.9 & 125106.6 & -- & -- & 273.4 & 12.34 & 27.34 & -- & -- \\
\hline 543 & PW-6S & 975004.8 & 124942.1 & 279.12 & TOC & 276.7 & 23.63 & 33.63 & -- & -- \\
\hline 544 & PW-6M & 975005.4 & 124932.2 & 279.10 & TPVC & 276.4 & 40.39 & 50.39 & -- & -- \\
\hline 545 & PW-6D & 975014.3 & 124943.8 & 279.01 & TOC & 277.0 & 87.6 & 97.6 & -- & 94 \\
\hline 546 & PW-6R & 975015.9 & 124934.2 & 278.58 & TOC & 276.3 & 101.04 & 111.04 & -- & 95 \\
\hline 501 & VP2001 & 975032.6 & 125199.6 & -- & -- & -- & -- & -- & -- & -- \\
\hline 403 & B95-08 & 975035.4 & 124825.8 & 276.26 & TPVC & 270.1 & 72 & 82 & -- & 88 \\
\hline 385 & P2-SG1 & 975037.3 & 125304.6 & 262.62 & $\begin{array}{l}\text { BOLT } \\
\text { HEAD }\end{array}$ & -- & -- & -- & -- & -- \\
\hline 568 & IW-2 & 975037.8 & 125068.4 & 268.44 & TSC & 277.0 & 67.8 & 87.8 & -- & -- \\
\hline 404 & B95-09 & 975039.8 & 124825.6 & 273.07 & TPVC & 270.3 & 10 & 20 & -- & -- \\
\hline 386 & P2-SG2 & 975040.9 & 125298.9 & 260.11 & SG2 & -- & -- & -- & -- & -- \\
\hline 387 & P2-SG3 & 975043.9 & 125294.6 & 260.11 & SG3 & -- & -- & -- & -- & -- \\
\hline 388 & P2-SG4 & 975045.6 & 125284.0 & 260.11 & SG4 & -- & -- & -- & -- & -- \\
\hline
\end{tabular}


Appendix 1. Information on wells and vertical profile points, Savage Municipal Well Superfund site, Milford, N.H.-Continued

[All units in feet; horizontal datum based on 2,000-foot grid New Hampshire State Planar coordinate system North American Datum 1983; vertical datum based on feet above NGVD 1929; depth in feet below land surface; well name descriptions on page ix; some wells not shown on plate 1; -- no data; wells sorted by easting location; Description of measurement point: $\mathrm{TSC}=$ top of steel casing; $\mathrm{TPVC}=$ top of polyvinyl chloride pipe; shelter $=$ top of shelter floor; $\mathrm{SG}=$ staff gage; SG2 = second staff gage; SG3 = third staff gage; SG4 = fourth staff gage; TCONC = top of concrete; RIM = rim of manhole cover; BOLT HEAD = top of bolt; WELLCVR = well cover; TINRSC $=$ top of inner steel casing; AHPUMP = air line reading at pump; top rebar $=$ top of rebar pipe; usgs disc $=$ top of usgs disc; VENT $=$ vent hole at pump]

\begin{tabular}{|c|c|c|c|c|c|c|c|c|c|c|}
\hline $\begin{array}{c}\text { Well } \\
\text { number }\end{array}$ & Well name & Easting & Northing & $\begin{array}{l}\text { Altitude of } \\
\text { measure- } \\
\text { ment point }\end{array}$ & $\begin{array}{l}\text { Descrip- } \\
\text { tion of } \\
\text { measure- } \\
\text { ment point }\end{array}$ & $\begin{array}{l}\text { Altitude of } \\
\text { land } \\
\text { surface }\end{array}$ & $\begin{array}{l}\text { Top of } \\
\text { opening } \\
\text { below } \\
\text { land } \\
\text { surface }\end{array}$ & $\begin{array}{l}\text { Bottom of } \\
\text { opening } \\
\text { below } \\
\text { land } \\
\text { surface }\end{array}$ & $\begin{array}{l}\text { Depth to } \\
\text { refusal } \\
\text { below } \\
\text { land } \\
\text { surface }\end{array}$ & $\begin{array}{c}\text { Depth to } \\
\text { bedrock } \\
\text { below } \\
\text { land } \\
\text { surface }\end{array}$ \\
\hline 38 & MI-24 & 975050.2 & 124966.3 & 272.63 & TPVC & 269.8 & 10 & 85 & -- & 96 \\
\hline 503 & VP2003 & 975053.1 & 125046.1 & -- & -- & -- & -- & -- & -- & -- \\
\hline 35 & MI-22 & 975053.7 & 125123.5 & 278.75 & TPVC & 269.1 & 99 & 114 & -- & 94 \\
\hline 37 & MI-23 & 975053.7 & 125123.5 & 278.75 & TPVC & 269.1 & 10 & 75 & -- & 94 \\
\hline 506 & VP2006 & 975054.5 & 125003.6 & -- & -- & -- & -- & -- & -- & -- \\
\hline 502 & VP2002 & 975054.8 & 125116.5 & -- & -- & -- & -- & -- & -- & -- \\
\hline 537 & PW-3D & 975056.3 & 125240.1 & 272.38 & TPVC & 269.8 & 84.85 & 94.85 & & 94.5 \\
\hline 419 & A08 & 975081.1 & 124581.5 & -- & -- & -- & -- & -- & -- & -- \\
\hline 505 & VP2005 & 975088.4 & 124827.3 & -- & -- & -- & -- & -- & -- & -- \\
\hline 40 & MI-25 & 975089.2 & 124821.7 & 272.18 & TPVC & 269.3 & 101.8 & 111 & -- & 105 \\
\hline 41 & MI-26 & 975089.2 & 124821.7 & 271.31 & TPVC & 269.3 & 8 & 88 & -- & 105 \\
\hline 39 & MI-24A & 975092.1 & 124891.9 & -- & -- & 272.0 & -- & 14 & -- & -- \\
\hline 336 & P-2 & 975100.9 & 125281.9 & 271.79 & shelter & 268.6 & 17 & 18 & -- & -- \\
\hline 567 & IW-1 & 975105.4 & 124871.1 & 269.91 & TSC & 272.4 & 73.75 & 103.75 & & 103.75 \\
\hline 52 & MI-38 & 975116.9 & 123948.1 & -- & -- & 270.0 & -- & -- & -- & -- \\
\hline 397 & B95-02 & 975120.7 & 125077.4 & -- & -- & 269.7 & -- & -- & -- & 99.8 \\
\hline 551 & PW-10M & 975142.3 & 125124.8 & 276.47 & TPVC & 274.0 & 50.15 & 60.15 & -- & -- \\
\hline 122 & WW-125 & 975152.7 & 129134.8 & -- & -- & 269.0 & -- & -- & -- & -- \\
\hline 571 & RW-3 & 975168.5 & 124805.8 & 268.79 & TSC & 270.0 & 18.45 & 28.45 & -- & -- \\
\hline 226 & MW-25 & 975168.9 & 123046.5 & 273.12 & TPVC & 270.5 & 4 & 12 & -- & -- \\
\hline 554 & PW-11D & 975172.4 & 125172.1 & 272.62 & TOC & 269.7 & 93.11 & 103.11 & -- & 101 \\
\hline 396 & B95-01 & 975177.4 & 124917.1 & -- & -- & 269.8 & -- & -- & -- & 107 \\
\hline 553 & PW-11M & 975180.9 & 125167.0 & 272.45 & TOC & 269.9 & 46.4 & 56.4 & -- & -- \\
\hline 509 & VP3002 & 975183.2 & 125171.2 & -- & -- & -- & -- & -- & -- & -- \\
\hline 512 & VP3005 & 975197.6 & 124894.6 & -- & -- & -- & -- & -- & -- & -- \\
\hline 540 & PW-5M & 975198.9 & 124963.3 & 275.88 & TPVC & 273.0 & 52.4 & 62.4 & -- & -- \\
\hline 225 & MW-26 & 975206.2 & 123141.4 & 271.11 & TPVC & 268.7 & 3 & 13 & -- & -- \\
\hline 541 & PW-5D & 975206.8 & 124969.2 & 275.13 & TPVC & 272.5 & 97.83 & 107.83 & -- & 106.5 \\
\hline 542 & PW-5R & 975206.9 & 124959.1 & 275.31 & TPVC & 272.5 & 122.76 & 132.76 & -- & 106 \\
\hline 510 & VP3003 & 975217.8 & 125071.9 & -- & -- & -- & -- & -- & -- & -- \\
\hline
\end{tabular}


Appendix 1. Information on wells and vertical profile points, Savage Municipal Well Superfund site, Milford, N.H.-Continued

[All units in feet; horizontal datum based on 2,000-foot grid New Hampshire State Planar coordinate system North American Datum 1983; vertical datum based on feet above NGVD 1929; depth in feet below land surface; well name descriptions on page ix; some wells not shown on plate 1; -- no data; wells sorted by easting location; Description of measurement point: $\mathrm{TSC}=$ top of steel casing; $\mathrm{TPVC}=$ top of polyvinyl chloride pipe; shelter = top of shelter floor; SG = staff gage; SG2 = second staff gage; SG3 = third staff gage; SG4 = fourth staff gage; TCONC = top of concrete; RIM = rim of manhole cover; BOLT HEAD = top of bolt; WELLCVR = well cover; TINRSC = top of inner steel casing; AHPUMP = air line reading at pump; top rebar = top of rebar pipe; usgs disc = top of usgs disc; VENT = vent hole at pump]

\begin{tabular}{|c|c|c|c|c|c|c|c|c|c|c|}
\hline $\begin{array}{c}\text { Well } \\
\text { number }\end{array}$ & Well name & Easting & Northing & $\begin{array}{l}\text { Altitude of } \\
\text { measure- } \\
\text { ment point }\end{array}$ & $\begin{array}{l}\text { Descrip- } \\
\text { tion of } \\
\text { measure- } \\
\text { ment point }\end{array}$ & $\begin{array}{c}\text { Altitude of } \\
\text { land } \\
\text { surface }\end{array}$ & $\begin{array}{l}\text { Top of } \\
\text { opening } \\
\text { below } \\
\text { land } \\
\text { surface }\end{array}$ & $\begin{array}{l}\text { Bottom of } \\
\text { opening } \\
\text { below } \\
\text { land } \\
\text { surface }\end{array}$ & $\begin{array}{l}\text { Depth to } \\
\text { refusal } \\
\text { below } \\
\text { land } \\
\text { surface }\end{array}$ & $\begin{array}{c}\text { Depth to } \\
\text { bedrock } \\
\text { below } \\
\text { land } \\
\text { surface }\end{array}$ \\
\hline 366 & MW-30 & 975228.8 & 125893.3 & 267.96 & $\mathrm{TSC}$ & -- & -- & -- & -- & -- \\
\hline 511 & VP3004 & 975233.4 & 124979.3 & -- & -- & -- & -- & -- & -- & -- \\
\hline 46 & MI-32 & 975247.2 & 124933.7 & 273.88 & shelter & 270.2 & 30 & 75 & -- & 95 \\
\hline 57 & MOW-63 & 975248.2 & 125062.1 & -- & -- & 270.0 & 53 & 62 & 65 & -- \\
\hline 409 & B95-15 & 975254.0 & 125149.4 & 268.23 & $\mathrm{TSC}$ & 269.6 & 85 & 95 & -- & 96.5 \\
\hline 535 & PW-2R & 975254.7 & 124973.6 & 273.27 & TPVC & 268.9 & 113.93 & 133.93 & -- & 102 \\
\hline 534 & PW-2D & 975255.1 & 124963.5 & 273.34 & TPVC & 269.7 & 96.17 & 106.17 & -- & 102 \\
\hline 532 & PW-2S & 975264.3 & 124962.1 & 271.04 & TPVC & 268.5 & 19.62 & 29.62 & -- & -- \\
\hline 533 & PW-2M & 975264.5 & 124972.7 & 270.54 & TPVC & 268.4 & 49.83 & 59.83 & -- & -- \\
\hline 418 & A07 & 975266.9 & 124527.1 & -- & -- & -- & -- & -- & -- & -- \\
\hline 191 & MOA-38 & 975295.4 & 125590.6 & -- & -- & 270.0 & -- & -- & 14 & -- \\
\hline 51 & MI-37 & 975299.5 & 123330.9 & 272.60 & TPVC & 270.4 & -- & 12.5 & -- & -- \\
\hline 347 & MW-4R & 975299.9 & 123581.5 & 268.47 & TSC & 266.4 & 64 & 98 & -- & 45 \\
\hline 212 & MW-4B & 975303.5 & 123583.8 & 268.59 & TPVC & 266.7 & 45.8 & 55.8 & -- & 43.2 \\
\hline 171 & MI-29 & 975306.9 & 123808.1 & 269.93 & TPVC & 268.5 & 31.5 & 51.5 & 51.5 & -- \\
\hline 312 & MW-4A & 975307.9 & 123586.4 & 268.34 & TPVC & 266.5 & 19.7 & 29.7 & -- & -- \\
\hline 513 & VP3006 & 975313.6 & 124781.6 & -- & -- & -- & -- & -- & -- & -- \\
\hline 407 & B95-12 & 975343.8 & 124724.7 & 272.32 & $\mathrm{TSC}$ & 269.5 & 55 & 60 & -- & 76 \\
\hline 66 & -- & 975354.0 & 124548.9 & -- & -- & 270.0 & -- & -- & -- & -- \\
\hline 299 & HM-1 & 975363.0 & 125252.3 & 269.05 & $\mathrm{TSC}$ & 269.2 & 3 & 83 & -- & -- \\
\hline 514 & VP4001 & 975384.6 & 125246.0 & -- & -- & -- & -- & -- & -- & -- \\
\hline 247 & RW1 & 975397.4 & 127471.0 & -- & -- & -2.0 & 59 & 340 & -- & -- \\
\hline 417 & A06 & 975407.3 & 124511.0 & -- & -- & -- & -- & -- & -- & -- \\
\hline 340 & SP-10 & 975407.8 & 126569.5 & 263.92 & -- & 262.4 & 1 & 6 & -- & -- \\
\hline 213 & MW-5B & 975408.3 & 123982.6 & 269.61 & TPVC & 267.6 & 50.4 & 60.4 & -- & 61.35 \\
\hline 313 & MW-5A & 975414.6 & 123981.8 & 269.71 & TPVC & 267.6 & 28 & 38 & -- & -- \\
\hline 248 & RW2 & 975425.1 & 127514.8 & -- & -- & -- & -- & -- & -- & -- \\
\hline 555 & PW-12S & 975427.3 & 125256.4 & 267.75 & TOC & 265.7 & 18.1 & 28.1 & -- & -- \\
\hline 557 & PW-12D & 975427.9 & 125266.2 & 267.68 & TOC & 265.7 & 87 & 97 & -- & -- \\
\hline 556 & PW-12M & 975437.2 & 125255.7 & 268.06 & TOC & 265.8 & 57.8 & 68 & -- & -- \\
\hline 558 & PW-12R & 975437.6 & 125267.4 & 267.78 & TOC & 265.7 & 113.9 & 134 & -- & 100 \\
\hline 408 & B95-13 & 975490.6 & 125002.0 & 266.35 & $\mathrm{TSC}$ & 267.0 & 60 & 65 & -- & 90.5 \\
\hline 249 & Cassarino & 975491.4 & 127480.1 & -- & -- & 267.9 & -- & 12.5 & -- & -- \\
\hline 566 & EW-2 & 975492.9 & 124936.3 & 265.81 & $\mathrm{TSC}$ & 267.1 & 51.22 & 81.22 & -- & 81.5 \\
\hline 530 & PW-1S & 975498.5 & 125008.0 & 266.91 & TOC & 267.0 & 26.02 & 36.02 & -- & \\
\hline 531 & PW-1D & 975507.1 & 125011.0 & 266.76 & TOC & 266.9 & 84.48 & 94.48 & -- & 94 \\
\hline 214 & MW-6B & 975521.2 & 124486.8 & 268.95 & TPVC & 267.1 & 56.8 & 66.8 & -- & 69.4 \\
\hline 348 & MW-6A & 975521.4 & 124481.8 & 269.11 & TPVC & 267.0 & 8 & 20 & -- & -- \\
\hline 565 & EW-1 & 975535.2 & 125046.1 & 265.09 & TSC & 266.9 & 63.55 & 93.55 & -- & -- \\
\hline 416 & A05 & 975549.3 & 124477.4 & -- & -- & -- & -- & -- & -- & -- \\
\hline
\end{tabular}


Appendix 1. Information on wells and vertical profile points, Savage Municipal Well Superfund site, Milford, N.H.-Continued

[All units in feet; horizontal datum based on 2,000-foot grid New Hampshire State Planar coordinate system North American Datum 1983; vertical datum based on feet above NGVD 1929; depth in feet below land surface; well name descriptions on page ix; some wells not shown on plate 1; -- no data; wells sorted by easting location; Description of measurement point: $\mathrm{TSC}=$ top of steel casing; $\mathrm{TPVC}=$ top of polyvinyl chloride pipe; shelter $=$ top of shelter floor; $\mathrm{SG}=$ staff gage; SG2 = second staff gage; SG3 = third staff gage; SG4 = fourth staff gage; TCONC = top of concrete; RIM = rim of manhole cover; BOLT HEAD = top of bolt; WELLCVR = well cover; TINRSC $=$ top of inner steel casing; AHPUMP = air line reading at pump; top rebar $=$ top of rebar pipe; usgs disc $=$ top of usgs disc; VENT $=$ vent hole at pump]

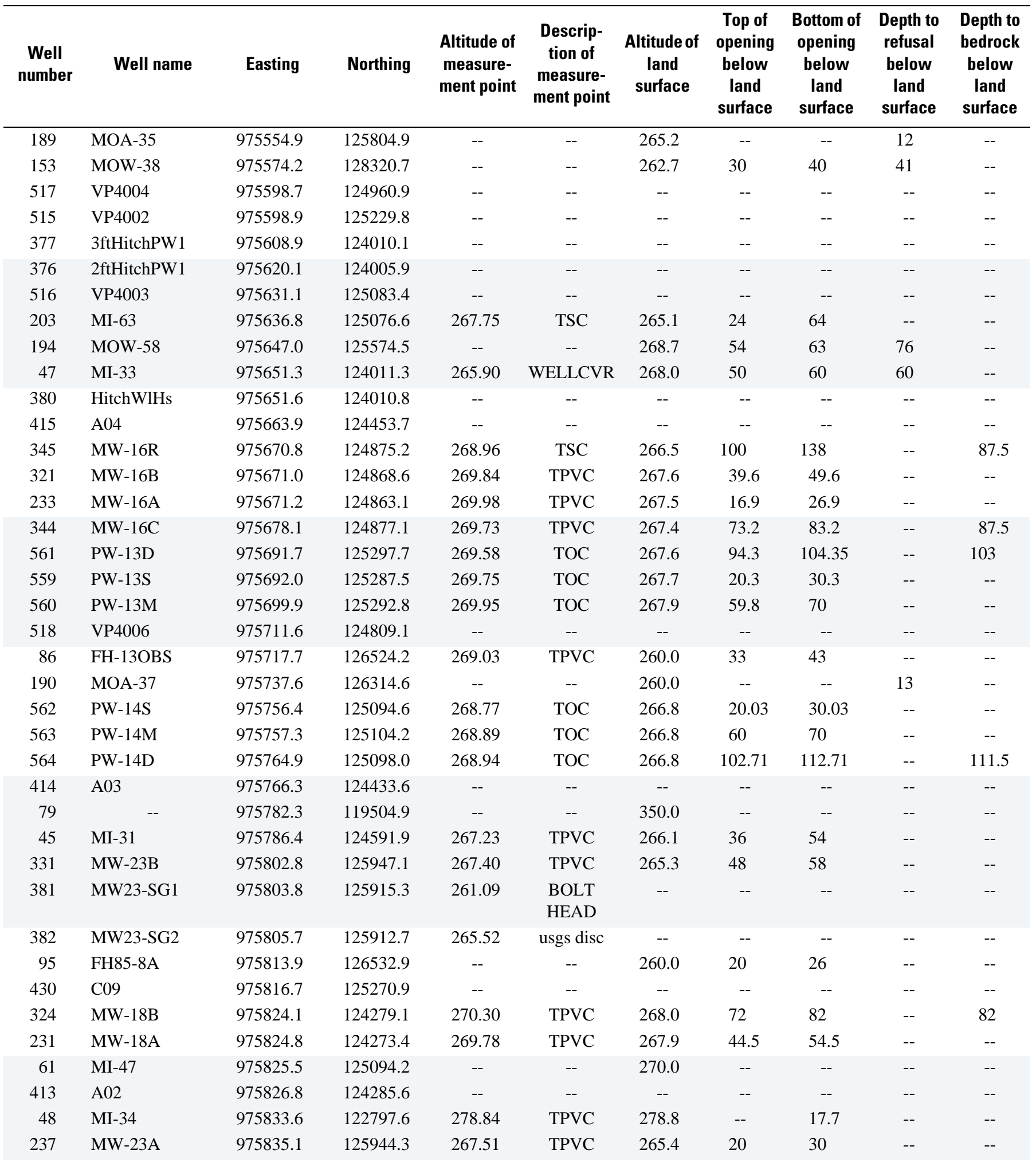


Appendix 1. Information on wells and vertical profile points, Savage Municipal Well Superfund site, Milford, N.H.-Continued

[All units in feet; horizontal datum based on 2,000-foot grid New Hampshire State Planar coordinate system North American Datum 1983; vertical datum based on feet above NGVD 1929; depth in feet below land surface; well name descriptions on page ix; some wells not shown on plate 1; -- no data; wells sorted by easting location; Description of measurement point: $\mathrm{TSC}=$ top of steel casing; $\mathrm{TPVC}=$ top of polyvinyl chloride pipe; shelter = top of shelter floor; SG = staff gage; SG2 = second staff gage; SG3 = third staff gage; SG4 = fourth staff gage; TCONC = top of concrete; RIM = rim of manhole cover; BOLT HEAD = top of bolt; WELLCVR = well cover; TINRSC = top of inner steel casing; AHPUMP = air line reading at pump; top rebar = top of rebar pipe; usgs disc = top of usgs disc; VENT = vent hole at pump]

\begin{tabular}{|c|c|c|c|c|c|c|c|c|c|c|}
\hline $\begin{array}{c}\text { Well } \\
\text { number }\end{array}$ & Well name & Easting & Northing & $\begin{array}{l}\text { Altitude of } \\
\text { measure- } \\
\text { ment point }\end{array}$ & $\begin{array}{l}\text { Descrip- } \\
\text { tion of } \\
\text { measure- } \\
\text { ment point }\end{array}$ & $\begin{array}{c}\text { Altitude of } \\
\text { land } \\
\text { surface }\end{array}$ & $\begin{array}{l}\text { Top of } \\
\text { opening } \\
\text { below } \\
\text { land } \\
\text { surface }\end{array}$ & $\begin{array}{l}\text { Bottom of } \\
\text { opening } \\
\text { below } \\
\text { land } \\
\text { surface }\end{array}$ & $\begin{array}{l}\text { Depth to } \\
\text { refusal } \\
\text { below } \\
\text { land } \\
\text { surface }\end{array}$ & $\begin{array}{c}\text { Depth to } \\
\text { bedrock } \\
\text { below } \\
\text { land } \\
\text { surface }\end{array}$ \\
\hline 188 & MOA-25 & 975839.7 & 125937.0 & -- & -- & 262.0 & 50 & 60 & 72 & -- \\
\hline 332 & MW-23C & 975840.8 & 125954.0 & 267.34 & TPVC & 265.3 & 84.3 & 94.3 & -- & 106 \\
\hline 412 & A01 & 975851.3 & 124173.6 & -- & -- & -- & -- & -- & -- & -- \\
\hline 87 & FH-14 & 975867.0 & 126592.8 & 263.53 & VENT & 262.2 & 32 & 42 & -- & -- \\
\hline 44 & MI-30 & 975877.3 & 124347.0 & 269.35 & TPVC & 265.7 & 27 & 72 & 75 & -- \\
\hline 59 & MI-45 & 975909.3 & 125772.4 & -- & -- & 264.9 & -- & -- & -- & -- \\
\hline 228 & MW-3 & 975915.6 & 123237.1 & 270.54 & TPVC & 268.7 & 11.5 & 21.5 & -- & 21.5 \\
\hline 80 & -- & 975917.3 & 119166.0 & -- & -- & -- & -- & -- & -- & -- \\
\hline 431 & C10 & 975918.7 & 125457.1 & -- & -- & -- & -- & -- & -- & -- \\
\hline 429 & C08 & 975946.1 & 125071.3 & -- & -- & -- & -- & -- & -- & -- \\
\hline 432 & $\mathrm{C} 11$ & 975949.1 & 125669.0 & -- & -- & -- & -- & -- & -- & -- \\
\hline 60 & MI-46 & 975970.8 & 125598.0 & -- & -- & 267.3 & -- & -- & -- & -- \\
\hline 580 & MW-101A & 975981.9 & 125600.9 & 266.55 & TPVC & -- & 9 & 19 & -- & -- \\
\hline 581 & MW-101B & 975984.5 & 125594.2 & 266.33 & TPVC & -- & 45 & 55 & -- & -- \\
\hline 582 & MW-101C & 975985.1 & 125588.7 & 265.73 & TSC & -- & 93 & 103 & 102.9 & 102.9 \\
\hline 422 & B04 & 975987.0 & 124364.6 & -- & -- & -- & -- & -- & -- & -- \\
\hline 208 & FH-10(PUMP) & 975988.3 & 127199.9 & 267.89 & TINRSC & 268.0 & 50 & 65 & -- & -- \\
\hline 301 & FH-11 & 975989.9 & 127199.8 & 268.08 & TSC & 267.4 & -- & 62 & -- & -- \\
\hline 240 & FH-10(OBS) & 975991.4 & 127198.4 & 268.01 & $\mathrm{TSC}$ & 267.3 & 58 & 63 & -- & -- \\
\hline 242 & FH-9 & 975997.3 & 127233.1 & 269.83 & $\mathrm{TSC}$ & 268.3 & -- & 52 & -- & -- \\
\hline 84 & \#226inSurv & 975999.6 & 127234.7 & 262.51 & $\mathrm{TSC}$ & 261.7 & 51 & 66 & -- & 60 \\
\hline 428 & $\mathrm{C} 07$ & 976004.9 & 124868.5 & -- & -- & -- & -- & -- & -- & -- \\
\hline 421 & B03 & 976012.1 & 124285.5 & -- & -- & -- & -- & -- & -- & -- \\
\hline 442 & D11 & 976033.8 & 126246.6 & -- & -- & -- & -- & -- & -- & -- \\
\hline 420 & B02 & 976040.8 & 124216.3 & -- & -- & -- & -- & -- & -- & -- \\
\hline 68 & -- & 976054.9 & 124695.2 & -- & -- & 267.9 & -- & -- & -- & -- \\
\hline 589 & SB-02 & 976069.8 & 125390.7 & -- & -- & 266.0 & -- & -- & 104. & -- \\
\hline 64 & -- & 976086.6 & 124426.6 & -- & -- & 265.3 & -- & -- & -- & -- \\
\hline 427 & C06 & 976100.7 & 124649.9 & -- & -- & -- & -- & -- & -- & -- \\
\hline 69 & -- & 976146.7 & 124676.0 & -- & -- & 266.3 & -- & -- & -- & -- \\
\hline 588 & SB-01 & 976165.9 & 125868.3 & -- & -- & 263.4 & -- & -- & 94.5 & -- \\
\hline 426 & $\mathrm{C} 05$ & 976169.6 & 124514.3 & -- & -- & -- & -- & -- & -- & -- \\
\hline 425 & $\mathrm{C} 03$ & 976190.0 & 124344.9 & -- & -- & -- & -- & -- & -- & -- \\
\hline 322 & MW-17B & 976212.0 & 124755.5 & 265.67 & TPVC & 264.6 & 52.4 & 62.4 & -- & -- \\
\hline 323 & MW-17C & 976212.8 & 124757.9 & 265.27 & TPVC & 264.7 & 85 & 95 & -- & 99.3 \\
\hline 218 & MW-10C & 976215.0 & 124930.6 & 264.74 & TPVC & 262.8 & 81.5 & 91.5 & -- & 91.6 \\
\hline 258 & MW-17A & 976216.5 & 124754.0 & 265.66 & TPVC & 264.4 & 19.8 & 29.8 & -- & -- \\
\hline 317 & MW-10B & 976218.5 & 124928.4 & 263.55 & TPVC & 262.2 & 44 & 54 & -- & -- \\
\hline 316 & MW-10A & 976221.5 & 124928.6 & 263.77 & TPVC & 262.2 & 19 & 29 & -- & -- \\
\hline 424 & $\mathrm{C} 02$ & 976230.6 & 124189.2 & -- & -- & -- & -- & -- & -- & -- \\
\hline
\end{tabular}


Appendix 1. Information on wells and vertical profile points, Savage Municipal Well Superfund site, Milford, N.H.-Continued

[All units in feet; horizontal datum based on 2,000-foot grid New Hampshire State Planar coordinate system North American Datum 1983; vertical datum based on feet above NGVD 1929; depth in feet below land surface; well name descriptions on page ix; some wells not shown on plate 1; -- no data; wells sorted by easting location; Description of measurement point: $\mathrm{TSC}=$ top of steel casing; $\mathrm{TPVC}=$ top of polyvinyl chloride pipe; shelter $=$ top of shelter floor; $\mathrm{SG}=$ staff gage; SG2 = second staff gage; SG3 = third staff gage; SG4 = fourth staff gage; TCONC = top of concrete; RIM = rim of manhole cover; BOLT HEAD = top of bolt; WELLCVR = well cover; TINRSC $=$ top of inner steel casing; AHPUMP = air line reading at pump; top rebar $=$ top of rebar pipe; usgs disc $=$ top of usgs disc; VENT $=$ vent hole at pump]

\begin{tabular}{|c|c|c|c|c|c|c|c|c|c|c|}
\hline $\begin{array}{c}\text { Well } \\
\text { number }\end{array}$ & Well name & Easting & Northing & $\begin{array}{l}\text { Altitude of } \\
\text { measure- } \\
\text { ment point }\end{array}$ & $\begin{array}{l}\text { Descrip- } \\
\text { tion of } \\
\text { measure- } \\
\text { ment point }\end{array}$ & $\begin{array}{l}\text { Altitude of } \\
\text { land } \\
\text { surface }\end{array}$ & $\begin{array}{l}\text { Top of } \\
\text { opening } \\
\text { below } \\
\text { land } \\
\text { surface }\end{array}$ & $\begin{array}{l}\text { Bottom of } \\
\text { opening } \\
\text { below } \\
\text { land } \\
\text { surface }\end{array}$ & $\begin{array}{l}\text { Depth to } \\
\text { refusal } \\
\text { below } \\
\text { land } \\
\text { surface }\end{array}$ & $\begin{array}{c}\text { Depth to } \\
\text { bedrock } \\
\text { below } \\
\text { land } \\
\text { surface }\end{array}$ \\
\hline 26 & MI-15 & 976242.8 & 123624.9 & 265.17 & TSC & 264.7 & -- & -- & -- & -- \\
\hline 169 & MI-9 & 976255.7 & 125936.0 & 265.05 & TCONC & 263.8 & -- & -- & -- & -- \\
\hline 215 & MW-7B & 976263.3 & 123908.4 & 264.29 & TPVC & 262.5 & 45.6 & 55.6 & -- & 58.6 \\
\hline 314 & MW-7A & 976267.6 & 123912.6 & 264.40 & TPVC & 262.3 & 3.2 & 13.2 & -- & -- \\
\hline 71 & -- & 976275.6 & 124553.6 & -- & -- & 264.0 & -- & -- & -- & -- \\
\hline 339 & SP-9 & 976276.6 & 126593.0 & 261.16 & -- & 259.4 & 1.5 & 6.5 & -- & -- \\
\hline 70 & -- & 976282.6 & 124669.8 & -- & -- & 264.1 & -- & -- & -- & -- \\
\hline 318 & MW-11A & 976433.3 & 125888.7 & 262.78 & TPVC & 260.9 & 20.5 & 30.5 & -- & -- \\
\hline 219 & MW-11R & 976435.0 & 125881.6 & 262.47 & TINRSC & 261.0 & 70 & 100.5 & -- & 65 \\
\hline 319 & MW-11B & 976435.2 & 125885.3 & 262.83 & TPVC & 261.0 & 52.3 & 64.3 & -- & 65 \\
\hline 590 & SB-03 & 976500.1 & 124641.6 & -- & -- & 262.5 & -- & -- & 90.5 & -- \\
\hline 351 & MW-9A & 976502.9 & 124485.8 & 267.76 & TPVC & 266.1 & 30.7 & 40.7 & -- & -- \\
\hline 217 & MW-9C & 976503.3 & 124473.6 & 268.09 & TPVC & 266.3 & 79 & 90 & -- & 94 \\
\hline 352 & MW-9B & 976503.6 & 124479.1 & 267.87 & TPVC & 266.1 & 58.2 & 68.2 & -- & -- \\
\hline 121 & -- & 976507.9 & 117660.4 & -- & -- & -- & -- & -- & -- & -- \\
\hline 591 & SB-04 & 976509.5 & 125564.3 & -- & -- & 262.6 & -- & -- & 63. & -- \\
\hline 315 & MW-8A & 976511.8 & 124151.8 & 263.91 & TPVC & 262.0 & 4.5 & 16.5 & -- & -- \\
\hline 443 & D21 & 976616.5 & 125429.2 & -- & -- & -- & -- & -- & -- & -- \\
\hline 154 & MOW-32 & 976679.8 & 124466.7 & -- & -- & 261.8 & 6 & 16 & 20 & -- \\
\hline 439 & D07 & 976690.2 & 125251.6 & -- & -- & -- & -- & -- & -- & -- \\
\hline 202 & MOW-19 & 976722.5 & 125725.6 & -- & -- & 260.8 & -- & -- & -- & -- \\
\hline 438 & D06 & 976751.4 & 125088.4 & -- & -- & -- & -- & -- & -- & -- \\
\hline 592 & SB-05(MW-102) & 976774.8 & 125063.3 & -- & -- & 259.7 & -- & -- & 73. & -- \\
\hline 252 & SP-6 & 976792.4 & 126621.2 & 261.05 & TPVC & 260.0 & 3 & 8 & -- & -- \\
\hline 27 & MI-16 & 976813.6 & 123543.9 & -- & -- & 269.1 & -- & -- & -- & -- \\
\hline 437 & D05 & 976816.8 & 124924.6 & -- & -- & -- & -- & -- & -- & -- \\
\hline 195 & MOW-64 & 976832.4 & 126380.5 & -- & -- & 260.0 & 41 & 49 & 76 & -- \\
\hline 111 & -- & 976843.4 & 115878.6 & -- & -- & -- & -- & -- & -- & -- \\
\hline 369 & FHwoods & 976854.1 & 127069.3 & 266.46 & TSC & 266.1 & -- & -- & -- & -- \\
\hline 593 & SB-06 & 976863.6 & 124649.0 & -- & -- & 262.1 & -- & -- & 83. & -- \\
\hline
\end{tabular}


Appendix 1. Information on wells and vertical profile points, Savage Municipal Well Superfund site, Milford, N.H.-Continued

[All units in feet; horizontal datum based on 2,000-foot grid New Hampshire State Planar coordinate system North American Datum 1983; vertical datum based on feet above NGVD 1929; depth in feet below land surface; well name descriptions on page ix; some wells not shown on plate 1; -- no data; wells sorted by easting location; Description of measurement point: $\mathrm{TSC}=$ top of steel casing; $\mathrm{TPVC}=$ top of polyvinyl chloride pipe; shelter $=$ top of shelter floor; $\mathrm{SG}=$ staff gage; SG2 = second staff gage; SG3 = third staff gage; SG4 = fourth staff gage; TCONC = top of concrete; RIM = rim of manhole cover; BOLT HEAD = top of bolt; WELLCVR = well cover; TINRSC $=$ top of inner steel casing; AHPUMP $=$ air line reading at pump; top rebar $=$ top of rebar pipe; usgs disc $=$ top of usgs disc; VENT $=$ vent hole at pump]

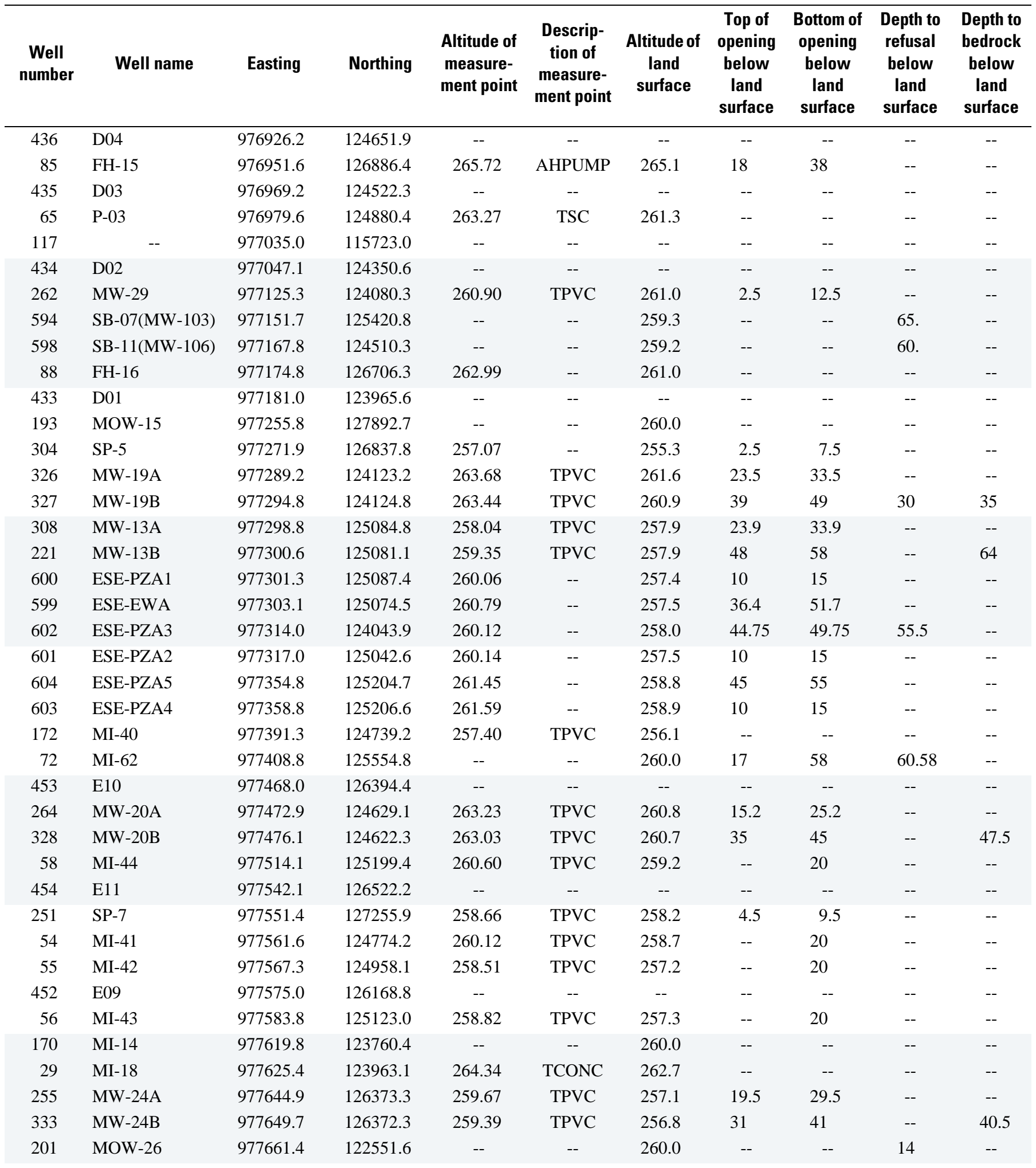


Appendix 1. Information on wells and vertical profile points, Savage Municipal Well Superfund site, Milford, N.H.—Continued

[All units in feet; horizontal datum based on 2,000-foot grid New Hampshire State Planar coordinate system North American Datum 1983; vertical datum based on feet above NGVD 1929; depth in feet below land surface; well name descriptions on page ix; some wells not shown on plate 1; -- no data; wells sorted by easting location; Description of measurement point: $\mathrm{TSC}=$ top of steel casing; $\mathrm{TPVC}=$ top of polyvinyl chloride pipe; shelter $=$ top of shelter floor; $\mathrm{SG}=$ staff gage; SG2 = second staff gage; SG3 = third staff gage; SG4 = fourth staff gage; TCONC = top of concrete; RIM = rim of manhole cover; BOLT HEAD = top of bolt; WELLCVR = well cover; TINRSC $=$ top of inner steel casing; AHPUMP $=$ air line reading at pump; top rebar $=$ top of rebar pipe; usgs disc $=$ top of usgs disc; VENT = vent hole at pump]

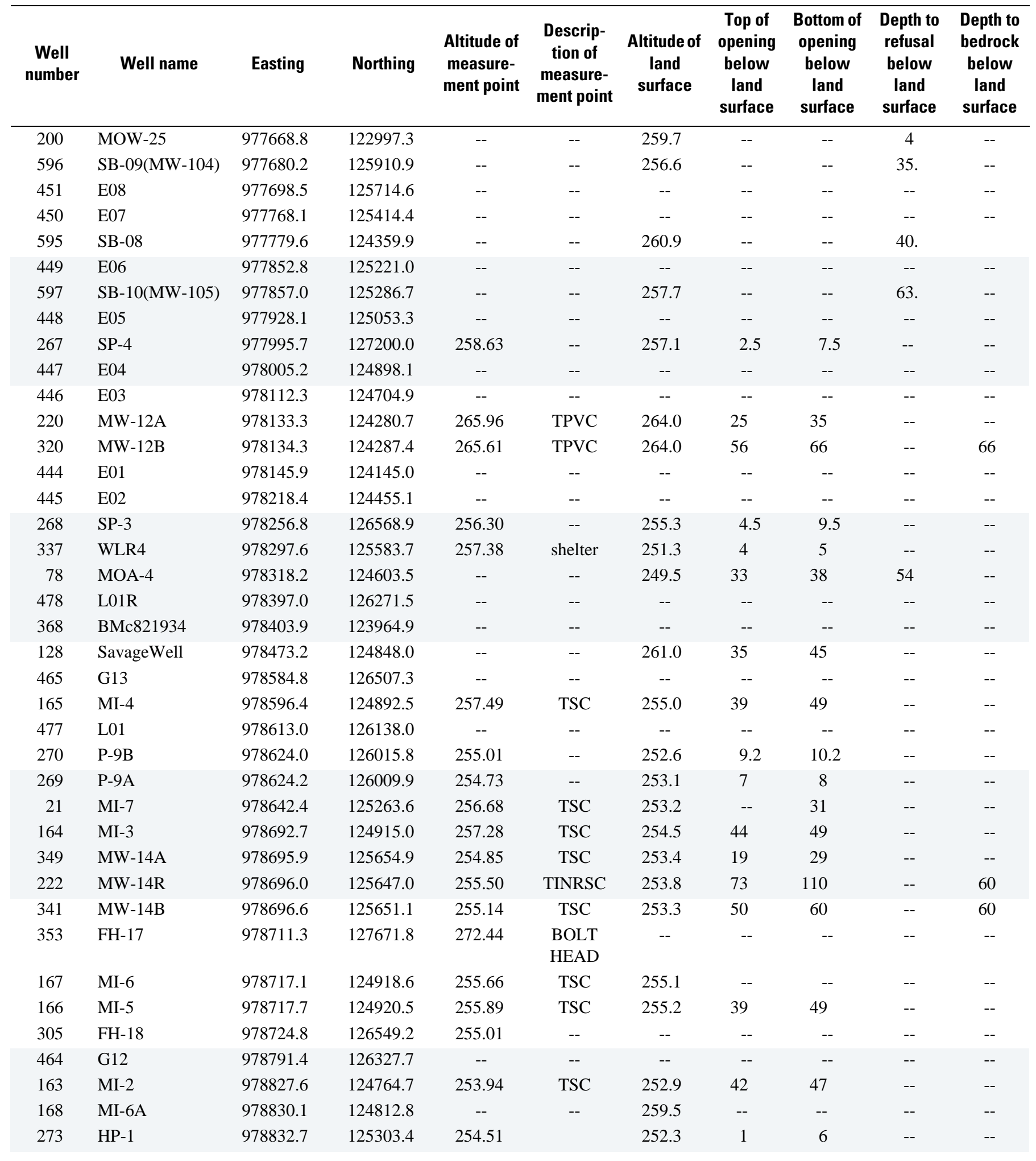


Appendix 1. Information on wells and vertical profile points, Savage Municipal Well Superfund site, Milford, N.H.-Continued

[All units in feet; horizontal datum based on 2,000-foot grid New Hampshire State Planar coordinate system North American Datum 1983; vertical datum based on feet above NGVD 1929; depth in feet below land surface; well name descriptions on page ix; some wells not shown on plate 1; -- no data; wells sorted by easting location; Description of measurement point: $\mathrm{TSC}=$ top of steel casing; $\mathrm{TPVC}=$ top of polyvinyl chloride pipe; shelter $=$ top of shelter floor; $\mathrm{SG}=$ staff gage; SG2 = second staff gage; SG3 = third staff gage; SG4 = fourth staff gage; TCONC = top of concrete; RIM = rim of manhole cover; BOLT HEAD = top of bolt; WELLCVR = well cover; TINRSC $=$ top of inner steel casing; AHPUMP $=$ air line reading at pump; top rebar $=$ top of rebar pipe; usgs disc $=$ top of usgs disc; VENT $=$ vent hole at pump]

\begin{tabular}{|c|c|c|c|c|c|c|c|c|c|c|}
\hline $\begin{array}{c}\text { Well } \\
\text { number }\end{array}$ & Well name & Easting & Northing & $\begin{array}{l}\text { Altitude of } \\
\text { measure- } \\
\text { ment point }\end{array}$ & $\begin{array}{l}\text { Descrip- } \\
\text { tion of } \\
\text { measure- } \\
\text { ment point }\end{array}$ & $\begin{array}{l}\text { Altitude of } \\
\text { land } \\
\text { surface }\end{array}$ & $\begin{array}{c}\text { Top of } \\
\text { opening } \\
\text { below } \\
\text { land } \\
\text { surface }\end{array}$ & $\begin{array}{l}\text { Bottom of } \\
\text { opening } \\
\text { below } \\
\text { land } \\
\text { surface }\end{array}$ & $\begin{array}{l}\text { Depth to } \\
\text { refusal } \\
\text { below } \\
\text { land } \\
\text { surface }\end{array}$ & $\begin{array}{c}\text { Depth to } \\
\text { bedrock } \\
\text { below } \\
\text { land } \\
\text { surface }\end{array}$ \\
\hline 302 & FH-19 & 978898.8 & 126408.4 & 256.17 & TSC & -- & -- & -- & -- & -- \\
\hline 375 & nearFH19 & 978900.7 & 126413.0 & -- & -- & -- & -- & -- & -- & -- \\
\hline 90 & FH-22 & 978953.0 & 126400.0 & 255.10 & TPVC & 253.1 & 24 & 29 & -- & -- \\
\hline 271 & P-15 & 978953.7 & 126170.9 & 252.08 & TPVC & 251.4 & 7 & 8 & -- & -- \\
\hline 463 & G11 & 978953.7 & 126217.3 & -- & -- & -- & -- & -- & -- & -- \\
\hline 89 & FH-27 & 978957.5 & 126176.8 & 251.45 & TPVC & 251.3 & 36 & 41 & -- & -- \\
\hline 334 & MW-31 & 978979.1 & 126191.9 & 251.87 & TSC & 250.1 & 60 & 273 & -- & 49 \\
\hline 329 & MW-21B & 979001.2 & 124469.8 & 261.77 & TPVC & 259.3 & 20 & 30 & -- & -- \\
\hline 278 & MW-21A & 979001.3 & 124463.6 & 261.27 & TPVC & 259.2 & 3.8 & 13.8 & -- & -- \\
\hline 330 & MW-21C & 979001.5 & 124474.0 & 261.34 & TPVC & 259.4 & 44.1 & 54.1 & -- & 63.75 \\
\hline 93 & FH-23 & 979002.6 & 126401.5 & 253.70 & TPVC & 252.0 & 22 & 25 & -- & -- \\
\hline 74 & MOW-35 & 979010.1 & 124641.8 & -- & -- & 260.0 & -- & -- & 59 & -- \\
\hline 91 & FH-24 & 979035.9 & 126403.9 & 253.27 & TPVC & 251.6 & 24 & 29 & -- & -- \\
\hline 466 & H02 & 979042.0 & 126437.2 & -- & -- & -- & -- & -- & -- & -- \\
\hline 306 & MW-33 & 979070.9 & 126468.1 & 254.52 & TSC & 251.8 & 41.5 & 51.5 & -- & 52.5 \\
\hline 609 & ESE-PZB4 & 979201.8 & 126071.2 & 256.21 & -- & 254.3 & 45 & 50 & -- & -- \\
\hline 606 & ESE-PZB1 & 979246.9 & 126084.3 & 256.72 & -- & 254.3 & 12 & 17 & -- & -- \\
\hline 607 & ESE-PZB2 & 979248.4 & 126086.4 & 256.98 & -- & 254.3 & 50 & 55 & -- & -- \\
\hline 605 & ESE-EWB & 979262.3 & 126082.9 & 256.10 & -- & 254.0 & 38.9 & 56 & -- & -- \\
\hline 479 & L02 & 979290.6 & 126300.6 & -- & -- & -- & -- & -- & -- & -- \\
\hline 275 & HP-3 & 979343.9 & 125403.5 & 253.53 & -- & 251.1 & 1.5 & 6.5 & -- & -- \\
\hline 461 & G09 & 979440.9 & 125972.7 & -- & -- & -- & -- & -- & -- & -- \\
\hline 610 & ESE-PZB5 & 979442.6 & 125971.7 & 253.81 & -- & 251.7 & 10 & 15 & -- & -- \\
\hline 276 & $\mathrm{P}-10$ & 979466.8 & 125859.0 & 252.70 & -- & 250.4 & 7.5 & 8.5 & -- & -- \\
\hline 460 & G08 & 979474.7 & 125812.3 & -- & -- & -- & -- & -- & -- & -- \\
\hline 459 & G07 & 979475.0 & 125626.0 & -- & -- & -- & -- & -- & -- & -- \\
\hline 25 & MI-12 & 979476.4 & 125858.7 & 253.26 & TSC & 251.5 & 43 & 49 & 50 & -- \\
\hline
\end{tabular}


Appendix 1. Information on wells and vertical profile points, Savage Municipal Well Superfund site, Milford, N.H.—Continued

[All units in feet; horizontal datum based on 2,000-foot grid New Hampshire State Planar coordinate system North American Datum 1983; vertical datum based on feet above NGVD 1929; depth in feet below land surface; well name descriptions on page ix; some wells not shown on plate 1; -- no data; wells sorted by easting location; Description of measurement point: $\mathrm{TSC}=$ top of steel casing; $\mathrm{TPVC}=$ top of polyvinyl chloride pipe; shelter $=$ top of shelter floor; $\mathrm{SG}=$ staff gage; SG2 = second staff gage; SG3 = third staff gage; SG4 = fourth staff gage; TCONC = top of concrete; RIM = rim of manhole cover; BOLT HEAD = top of bolt; WELLCVR = well cover; TINRSC $=$ top of inner steel casing; AHPUMP = air line reading at pump; top rebar $=$ top of rebar pipe; usgs disc $=$ top of usgs disc; VENT = vent hole at pump]

\begin{tabular}{|c|c|c|c|c|c|c|c|c|c|c|}
\hline $\begin{array}{c}\text { Well } \\
\text { number }\end{array}$ & Well name & Easting & Northing & $\begin{array}{l}\text { Altitude of } \\
\text { measure- } \\
\text { ment point }\end{array}$ & $\begin{array}{l}\text { Descrip- } \\
\text { tion of } \\
\text { measure- } \\
\text { ment point }\end{array}$ & $\begin{array}{l}\text { Altitude of } \\
\text { land } \\
\text { surface }\end{array}$ & $\begin{array}{l}\text { Top of } \\
\text { opening } \\
\text { below } \\
\text { land } \\
\text { surface }\end{array}$ & $\begin{array}{c}\text { Bottom of } \\
\text { opening } \\
\text { below } \\
\text { land } \\
\text { surface }\end{array}$ & $\begin{array}{l}\text { Depth to } \\
\text { refusal } \\
\text { below } \\
\text { land } \\
\text { surface }\end{array}$ & $\begin{array}{c}\text { Depth to } \\
\text { bedrock } \\
\text { below } \\
\text { land } \\
\text { surface }\end{array}$ \\
\hline 480 & L03 & 979520.8 & 126351.7 & -- & -- & -- & -- & -- & -- & -- \\
\hline 24 & MI-11 & 979580.1 & 125310.7 & 254.52 & TSC & 252.1 & 40 & 56 & 63 & -- \\
\hline 458 & G06 & 979635.0 & 125491.7 & -- & -- & -- & -- & -- & -- & -- \\
\hline 23 & MI-10 & 979677.4 & 124853.9 & 255.12 & TPVC & 252.2 & 44 & 47 & -- & 58.5 \\
\hline 277 & P-11 & 979689.2 & 126100.9 & 254.54 & -- & 252.5 & 7.5 & 8.5 & -- & -- \\
\hline 481 & L04 & 979734.1 & 126310.9 & -- & -- & -- & -- & -- & -- & -- \\
\hline 457 & G05 & 979735.0 & 125352.0 & -- & -- & -- & -- & -- & -- & -- \\
\hline 67 & -- & 979957.1 & 124233.7 & -- & -- & 250.0 & -- & -- & -- & -- \\
\hline 280 & P-16 & 979986.6 & 126500.0 & 260.43 & TPVC & 258.3 & 12 & 13 & -- & -- \\
\hline 281 & MW-34 & 979987.0 & 126490.7 & 260.91 & TPVC & 258.5 & 9.5 & 19.5 & -- & 20.5 \\
\hline 14 & RFW-1 & 980111.6 & 123484.1 & -- & -- & 255.7 & 8 & 28 & 28 & -- \\
\hline 283 & P-17B & 980124.1 & 126110.1 & 253.66 & -- & 252.6 & 12 & 13 & -- & -- \\
\hline 282 & P-17A & 980125.1 & 126109.1 & 252.54 & -- & 250.6 & 8 & 9 & -- & -- \\
\hline 17 & RFW-4 & 980142.7 & 124069.5 & 252.15 & -- & 251.6 & 6 & 16 & 16 & -- \\
\hline 18 & PA-1 & 980332.1 & 123667.2 & -- & -- & 255.1 & -- & 8.7 & -- & -- \\
\hline 19 & PA-2 & 980334.7 & 123737.3 & -- & -- & 254.9 & -- & 8.7 & -- & -- \\
\hline 361 & P-12 & 980380.2 & 125709.4 & 252.03 & -- & 252.0 & 9 & 10 & -- & -- \\
\hline 585 & WLR-5 rebar & 980644.9 & 126283.6 & 245.24 & top rebar & -- & -- & -- & -- & -- \\
\hline 285 & SPZ-2 & 980666.6 & 126449.9 & 252.23 & TPVC & 250.2 & 3.5 & 8.5 & -- & -- \\
\hline 475 & K04 & 980675.5 & 126332.7 & -- & -- & -- & -- & -- & -- & -- \\
\hline 468 & $\mathrm{~J} 03$ & 980935.1 & 124692.0 & -- & -- & -- & -- & -- & -- & -- \\
\hline 467 & $\mathrm{~J} 02$ & 980936.7 & 124496.2 & -- & -- & -- & -- & -- & -- & -- \\
\hline 476 & K06 & 981000.1 & 126333.8 & -- & -- & -- & -- & -- & -- & -- \\
\hline 288 & FH-28 & 981031.7 & 126543.6 & 248.85 & TSC & 248.1 & -- & 23 & -- & -- \\
\hline 290 & SP-18 & 981032.5 & 126481.6 & 250.17 & -- & 248.2 & 4.5 & 7.5 & -- & -- \\
\hline 289 & FH-29 & 981063.3 & 126519.2 & 250.07 & TSC & 247.8 & -- & 33.9 & -- & -- \\
\hline 294 & MW-22B & 981098.7 & 126201.3 & 252.77 & TPVC & 250.1 & 33.5 & 43.5 & -- & 47 \\
\hline 293 & MW-22A & 981102.3 & 126204.0 & 252.52 & TPVC & 250.2 & 13.8 & 23.8 & -- & -- \\
\hline 292 & FH-30 & 981104.8 & 126341.0 & 250.69 & TSC & 248.3 & -- & 23 & -- & -- \\
\hline 287 & RW9 & 981114.8 & 127599.2 & 271.45 & -- & 270.4 & -- & 22 & -- & -- \\
\hline
\end{tabular}


Appendix 1. Information on wells and vertical profile points, Savage Municipal Well Superfund site, Milford, N.H.-Continued

[All units in feet; horizontal datum based on 2,000-foot grid New Hampshire State Planar coordinate system North American Datum 1983; vertical datum based on feet above NGVD 1929; depth in feet below land surface; well name descriptions on page ix; some wells not shown on plate 1; -- no data; wells sorted by easting location; Description of measurement point: $\mathrm{TSC}=$ top of steel casing; $\mathrm{TPVC}=$ top of polyvinyl chloride pipe; shelter $=$ top of shelter floor; $\mathrm{SG}=$ staff gage; SG2 = second staff gage; SG3 = third staff gage; SG4 = fourth staff gage; TCONC = top of concrete; RIM = rim of manhole cover; BOLT HEAD = top of bolt; WELLCVR = well cover; TINRSC $=$ top of inner steel casing; AHPUMP = air line reading at pump; top rebar $=$ top of rebar pipe; usgs disc $=$ top of usgs disc; VENT $=$ vent hole at pump]

\begin{tabular}{|c|c|c|c|c|c|c|c|c|c|c|}
\hline $\begin{array}{c}\text { Well } \\
\text { number }\end{array}$ & Well name & Easting & Northing & $\begin{array}{l}\text { Altitude of } \\
\text { measure- } \\
\text { ment point }\end{array}$ & $\begin{array}{l}\text { Descrip- } \\
\text { tion of } \\
\text { measure- } \\
\text { ment point }\end{array}$ & $\begin{array}{l}\text { Altitude of } \\
\text { land } \\
\text { surface }\end{array}$ & $\begin{array}{l}\text { Top of } \\
\text { opening } \\
\text { below } \\
\text { land } \\
\text { surface }\end{array}$ & $\begin{array}{l}\text { Bottom of } \\
\text { opening } \\
\text { below } \\
\text { land } \\
\text { surface }\end{array}$ & $\begin{array}{l}\text { Depth to } \\
\text { refusal } \\
\text { below } \\
\text { land } \\
\text { surface }\end{array}$ & $\begin{array}{c}\text { Depth to } \\
\text { bedrock } \\
\text { below } \\
\text { land } \\
\text { surface }\end{array}$ \\
\hline 360 & -- & 981136.4 & 126667.9 & 251.03 & TSC & 247.1 & -- & 34.5 & -- & -- \\
\hline 359 & FH-? & 981138.8 & 126516.3 & 249.86 & TSC & 248.5 & -- & 24.8 & -- & -- \\
\hline 354 & PFHprodWell & 981195.6 & 126601.6 & 251.68 & -- & 249.2 & 30 & 40 & -- & -- \\
\hline 356 & -- & 981217.3 & 126573.6 & 250.05 & -- & 247.4 & -- & -- & -- & -- \\
\hline 357 & -- & 981218.6 & 126572.1 & 249.97 & -- & 247.4 & -- & -- & -- & -- \\
\hline 473 & J08 & 981224.7 & 125972.8 & -- & -- & -- & -- & -- & -- & -- \\
\hline 471 & J06 & 981367.5 & 125313.4 & -- & -- & -- & -- & -- & -- & -- \\
\hline 297 & MW-32B & 981369.8 & 125487.1 & 251.23 & TPVC & 248.3 & 31.8 & 41.8 & -- & 43.5 \\
\hline 470 & J05 & 981370.2 & 125136.7 & -- & -- & -- & -- & -- & -- & -- \\
\hline 469 & J04 & 981371.5 & 124939.3 & -- & -- & -- & -- & -- & -- & -- \\
\hline 174 & H11-71 & 981478.2 & 125561.4 & -- & -- & 241.6 & 25 & 35 & -- & 39 \\
\hline 175 & H9-71 & 981665.1 & 126217.4 & -- & -- & 250.8 & 20 & 25 & -- & 28.5 \\
\hline 180 & H5-71 & 981751.4 & 126415.0 & -- & -- & 250.5 & 23 & 28 & -- & 31 \\
\hline 295 & P-13 & 981806.6 & 126346.1 & 250.84 & -- & 248.3 & 7.5 & 8.5 & -- & -- \\
\hline 179 & H10-71 & 981819.4 & 126331.6 & -- & -- & 250.9 & 18 & 28 & -- & 34 \\
\hline 485 & P02 & 981887.1 & 125105.9 & -- & -- & -- & -- & -- & -- & -- \\
\hline 342 & MW-15B & 982001.4 & 125914.5 & 258.61 & TPVC & 257.0 & 29.4 & 36.4 & -- & 27.5 \\
\hline 223 & MW-15A & 982006.4 & 125915.3 & 258.53 & TPVC & 256.8 & 12.5 & 27.5 & -- & -- \\
\hline 83 & -- & 982062.2 & 125393.9 & -- & -- & 240.9 & -- & -- & -- & -- \\
\hline 82 & -- & 982214.8 & 125347.6 & -- & -- & 240.0 & -- & -- & -- & 23 \\
\hline 107 & -- & 982412.5 & 131350.5 & -- & -- & 349.2 & -- & -- & -- & -- \\
\hline 109 & -- & 982510.9 & 130710.2 & -- & -- & 349.3 & -- & -- & -- & -- \\
\hline 123 & GW-01S & 982781.1 & 127851.5 & -- & -- & 256.1 & 6 & 16 & -- & -- \\
\hline 124 & GW-01D & 982862.3 & 127876.4 & -- & -- & 256.5 & 60 & 70 & -- & 56 \\
\hline 197 & MOW-66 & 982904.6 & 124297.2 & -- & -- & 252.8 & 27 & 33 & 37 & -- \\
\hline 125 & GW-01M & 982953.4 & 127904.3 & -- & -- & 256.7 & 30 & 40 & -- & -- \\
\hline 198 & MOW-67 & 983164.5 & 124318.2 & -- & -- & 249.8 & 37 & 43 & 45 & -- \\
\hline 155 & GW-02S & 983400.8 & 127487.9 & -- & -- & 255.1 & 6 & 16 & -- & -- \\
\hline
\end{tabular}


Appendix 1. Information on wells and vertical profile points, Savage Municipal Well Superfund site, Milford, N.H.-Continued

[All units in feet; horizontal datum based on 2,000-foot grid New Hampshire State Planar coordinate system North American Datum 1983; vertical datum based on feet above NGVD 1929; depth in feet below land surface; well name descriptions on page ix; some wells not shown on plate 1; -- no data; wells sorted by easting location; Description of measurement point: $\mathrm{TSC}=$ top of steel casing; $\mathrm{TPVC}=$ top of polyvinyl chloride pipe; shelter $=$ top of shelter floor; $\mathrm{SG}=$ staff gage; SG2 = second staff gage; SG3 = third staff gage; SG4 = fourth staff gage; TCONC = top of concrete; RIM = rim of manhole cover; BOLT HEAD = top of bolt; WELLCVR = well cover; TINRSC $=$ top of inner steel casing; AHPUMP $=$ air line reading at pump; top rebar $=$ top of rebar pipe; usgs disc $=$ top of usgs disc; VENT $=$ vent hole at pump]

\begin{tabular}{|c|c|c|c|c|c|c|c|c|c|c|}
\hline $\begin{array}{c}\text { Well } \\
\text { number }\end{array}$ & Well name & Easting & Northing & $\begin{array}{l}\text { Altitude of } \\
\text { measure- } \\
\text { ment point }\end{array}$ & $\begin{array}{l}\text { Descrip- } \\
\text { tion of } \\
\text { measure- } \\
\text { ment point }\end{array}$ & $\begin{array}{c}\text { Altitude of } \\
\text { land } \\
\text { surface }\end{array}$ & $\begin{array}{l}\text { Top of } \\
\text { opening } \\
\text { below } \\
\text { land } \\
\text { surface }\end{array}$ & $\begin{array}{c}\text { Bottom of } \\
\text { opening } \\
\text { below } \\
\text { land } \\
\text { surface }\end{array}$ & $\begin{array}{l}\text { Depth to } \\
\text { refusal } \\
\text { below } \\
\text { land } \\
\text { surface }\end{array}$ & $\begin{array}{c}\text { Depth to } \\
\text { bedrock } \\
\text { below } \\
\text { land } \\
\text { surface }\end{array}$ \\
\hline 199 & MOW-68 & 983417.4 & 124322.2 & -- & -- & 245.0 & 36 & 42 & 53 & -- \\
\hline 157 & GW-04S & 983770.6 & 127239.5 & -- & -- & 255.6 & 5.4 & 15.4 & -- & -- \\
\hline 158 & GW-05S & 984189.9 & 127055.1 & -- & -- & 264.2 & 7 & 17 & -- & -- \\
\hline 156 & GW-03S & 984191.2 & 126042.6 & -- & -- & 252.4 & 8.4 & 18.4 & -- & -- \\
\hline 204 & MI-13 & 984325.5 & 123765.2 & 251.42 & -- & 249.6 & 12 & 18 & 33 & -- \\
\hline 150 & LW-02S & 984495.9 & 124860.8 & 245.91 & -- & 243.4 & 4 & 14 & -- & -- \\
\hline 148 & LW-01M & 984856.9 & 125418.5 & -- & -- & 265.1 & 42.6 & 52.6 & -- & -- \\
\hline
\end{tabular}





\section{Appendix 2}

Information on historical withdrawals from pre-1960 to December 1988, and simulated stress periods for historical calibration, Savage Municipal Well Superfund site, Milford, N.H. 
Appendix 2. Information on historical withdrawals from pre-1960 to December 1988, and simulated stress periods for historical calibration, Savage Municipal Well Superfund site, Milford, N.H.

$[<$, less than; --, unknown; to convert withdrawals to millions of gallons per day, multiply by 0.646; Table modified from Harte and Willey (1997)]

\begin{tabular}{|c|c|c|c|}
\hline \multirow{2}{*}{$\begin{array}{c}\text { Simulation time } \\
\text { period }\end{array}$} & \multirow{2}{*}{$\begin{array}{c}\text { Total } \\
\text { withdrawals, } \\
\text { in cubic feet } \\
\text { per second }\end{array}$} & \multicolumn{2}{|c|}{ Percent of withdrawals } \\
\hline & & $\begin{array}{l}\text { North of the } \\
\text { Souhegan River }\end{array}$ & $\begin{array}{c}\text { South of the } \\
\text { Souhegan River }\end{array}$ \\
\hline Pre-1960 & $<0.1$ & -- & -- \\
\hline 1960-1964 & .32 & 0 & 100 \\
\hline $1965-1970$ & .88 & 0 & 100 \\
\hline 1971-1973 & 2.21 & 60 & 40 \\
\hline $\begin{array}{l}\text { September } 1974- \\
\text { January } 1976\end{array}$ & 2.30 & 50 & 50 \\
\hline $\begin{array}{l}\text { October } 1976- \\
\text { January } 1983\end{array}$ & 2.82 & 60 & 40 \\
\hline $\begin{array}{l}\text { February } 1983- \\
\text { September } 1986\end{array}$ & 2.16 & 62 & 38 \\
\hline $\begin{array}{l}\text { October } 1986- \\
\text { December } 1987\end{array}$ & 3.16 & 74 & 26 \\
\hline $\begin{array}{l}\text { January } 1988- \\
\text { December } 1988\end{array}$ & 4.38 & 81 & 19 \\
\hline
\end{tabular}

\section{Reference}

Harte, P.T., and Willey, R.E., 1997, Effects of historical withdrawals on advective transport of contaminated ground waters in a glacial-drift aquifer, Milford, New Hampshire: U.S. Geological Survey Fact Sheet FS 162-97, 6 p. 


\section{Appendix 3}

Summary of selected model runs for historical, pre-remedial, and remedial simulations, Savage Municipal Well Superfund site, Milford, N.H. 
$\mathrm{O}=\mathrm{O}$ values similar to that as reported in Harte (1999; see references)

$M=$ values adjusted from that reported in Harte (1999; see references)

AVG = Two dimensional bulk average from three-dimensional model reported in Harte (1999; see references)

$3 \mathrm{~F}=$ Values multiplied by a factor of three

$\mathrm{VR}=$ ratio values vary spatially

$\mathrm{mz}=$ middle zone of layer

$\mathrm{MI}=$ mass input

$\mathrm{IRR}=$ irreversible reaction rate

NS $=$ Not simulated

$\mathrm{TV}=$ Time variable rate during simulation

11 = layer 1

12 = layer 2

13 = layer 3

$14=$ layer 4

$15=$ layer 5

$\mathrm{ft} / \mathrm{d}=$ feet per day

cfs = cubic feet per second

$\mathrm{mFg}=$ millions of grams

$\mathrm{gm} / \mathrm{min}=$ grams per minute

$\mathrm{V}=$ volatilization only simulated

$\mathrm{Dg}+\mathrm{V}=$ degradation and volatilization simulated

$\mathrm{SS}=$ steady state simulation

$\mathrm{SPY}=$ specific yield

$\mathrm{SC}=$ storage coefficient

$\mathrm{K}=$ horizontal hydraulic conductivity

$\mathrm{Kn}=$ horizontal hydraulic conductivity for layer $\mathrm{n},(2,3,4,5$, etc. $)$

$\mathrm{VKn}=$ vertical hydraulic conductivity for layer $\mathrm{n},(2,3,4,5$, etc. $)$

$\mathrm{HA}=$ horizontal anistropy

RIV = river data set

$\mathrm{RCH}=$ recharge

$\mathrm{R}=$ retardation

$\mathrm{D}=$ dispersivity

$\mathrm{CHFB}=$ MODFLOW Ground-Water Transport package to compute Concentrations across Hydraulic Flow Boundaries 


\begin{tabular}{|c|c|c|c|c|c|c|c|c|c|c|c|c|c|c|c|c|c|c|c|c|c|c|c|}
\hline \multirow[t]{2}{*}{ Simulation } & \multirow[t]{2}{*}{$\begin{array}{c}\text { Model run } \\
\text { number }\end{array}$} & \multirow[t]{2}{*}{$\begin{array}{c}\text { Major } \\
\text { parameter } \\
\text { tested } \\
\end{array}$} & \multirow[t]{2}{*}{$\begin{array}{l}\text { Recharge } \\
\text { rate, in cfs }\end{array}$} & \multirow[t]{2}{*}{$\begin{array}{c}\text { Extraction/in } \\
\text { jection } \\
\text { rates, in cfs }\end{array}$} & \multicolumn{5}{|c|}{ Horizontal hydraulic conductivity } & \multicolumn{5}{|c|}{ Vertical hydraulic conductivity as a ratio of horizontal } & \multirow[t]{2}{*}{$\begin{array}{c}\begin{array}{c}\text { Porosity, } \\
\text { ratio }\end{array} \\
\end{array}$} & \multirow[t]{2}{*}{$\begin{array}{c}\begin{array}{c}\text { Storage } \\
\text { properties }\end{array} \\
\end{array}$} & \multirow[t]{2}{*}{\begin{tabular}{|l}
$\begin{array}{r}\text { Retardation, } \\
\text { coefficient }\end{array}$ \\
\end{tabular}} & \multicolumn{3}{|c|}{ Dispersivity, in feet } & \multirow[t]{2}{*}{$\begin{array}{c}\text { Initial PCE } \\
\text { mass, in } \\
\text { mFg }\end{array}$} & \multirow[t]{2}{*}{$\begin{array}{l}\text { Source of } \\
\text { PCE, begin } \\
\text { date in year } \\
\text { and rate of } \\
\text { PCE input, } \\
\text { in gm/min } \\
\end{array}$} & \multirow[t]{2}{*}{$\begin{array}{l}\text { Degradation } \\
\text { volatilizatio } \\
\text { n, decay } \\
\text { function } \\
\end{array}$} \\
\hline & & & & & Layer one & Layer two & Layer three & Layer four & Layer five & Layer one & Layer two & Layer three & Layer four & Layer five & & & & $\begin{array}{c}\text { Longitudi } \\
\text { nal }\end{array}$ & $\begin{array}{c}\text { ransver: } \\
\text { e }\end{array}$ & Vertical & & & \\
\hline \multirow{15}{*}{ 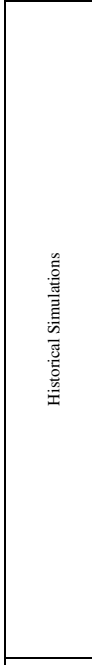 } & 5 & MI & 3.3 & TV & \multicolumn{5}{|c|}{ AVG } & \multicolumn{5}{|c|}{ NS } & 0.3 & 0.23 & 4 & 60 & 6 & NS & 0 & $1960(0.01)$ & $\begin{array}{c}\text { Dg+V;2.2.2- } \\
9\end{array}$ \\
\hline & 8 & MI & 3.3 & TV & \multicolumn{5}{|c|}{ AVG } & \multicolumn{5}{|c|}{ NS } & 0.3 & 0.23 & 4 & 60 & 6 & NS & 0 & $1960(0.1)$ & $\begin{array}{c}\text { DgtV; } ; 2.2 \mathrm{E}- \\
9\end{array}$ \\
\hline & 9 & MI & 3.3 & TV & \multicolumn{5}{|c|}{ AVG } & \multicolumn{5}{|c|}{ NS } & 0.3 & 0.23 & 4 & 60 & 6 & NS & 0 & $1960(1.0)$ & $\begin{array}{c}\text { DgtV; } ; 2.2 \mathrm{E}- \\
9\end{array}$ \\
\hline & 10 & MI & 3.3 & $\mathrm{TV}$ & \multicolumn{5}{|c|}{ AVG } & \multicolumn{5}{|c|}{ NS } & 0.3 & 0.23 & 4 & 60 & 6 & NS & 0 & $1950(1.0)$ & $\begin{array}{c}\text { DgtV+2;2.2E- } \\
9\end{array}$ \\
\hline & $\begin{array}{l}11 \\
12\end{array}$ & $\begin{array}{l}\text { IRR } \\
\text { IRR }\end{array}$ & $\begin{array}{l}3.3 \\
3.3 \\
\end{array}$ & $\begin{array}{l}\text { TV } \\
\text { TV }\end{array}$ & \multicolumn{5}{|c|}{$\begin{array}{l}\mathrm{AVG} \\
\mathrm{AVG} \\
\end{array}$} & & & $\frac{\mathrm{NS}}{\mathrm{NS}}$ & & & $\begin{array}{l}0.3 \\
0.3 \\
\end{array}$ & $\begin{array}{l}0.23 \\
0.23\end{array}$ & $\begin{array}{l}4 \\
0\end{array}$ & $\frac{60}{0}$ & 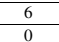 & $\begin{array}{l}\text { NS } \\
\text { NS }\end{array}$ & $\begin{array}{l}0 \\
0\end{array}$ & $\frac{1950(1.0)}{109010}$ & \begin{tabular}{|l|}
0 \\
\end{tabular} \\
\hline & 13 & $\mathrm{R}$ & 3.3 & $\mathrm{TV}$ & & & AVG & & & & & NS & & & 0.3 & 0.23 & 2 & 54 & 12 & NS & 0 & $1960(1.0)$ & $\begin{array}{c}\mathrm{Dg}+\mathrm{V} ; 2.2 \mathrm{E}- \\
9\end{array}$ \\
\hline & 14 & $\mathrm{R}$ & 3.3 & $\mathrm{TV}$ & & & AVG & & & & & NS & & & 0.3 & 0.23 & 2.5 & 54 & 12 & NS & 0 & $1960(0.75)$ & $\begin{array}{c}\text { DgtV; } ; 2.2 \mathrm{E}- \\
9\end{array}$ \\
\hline & 15 & $\mathrm{R}$ & 3.3 & $\mathrm{TV}$ & & & AVG & & & & & NS & & & 0.3 & 0.23 & 4 & 60 & 6 & NS & 0 & $1960(1.0)$ & $\begin{array}{c}\text { DgtV; } ; 2.2 \mathrm{E}- \\
9\end{array}$ \\
\hline & 16 & $\mathrm{~K}, \mathrm{D}, \mathrm{MI}$ & 3.3 & $\mathrm{TV}$ & & & -fold increase o & of AVG & & & & NS & & & 0.3 & 0.23 & 4 & 180 & 18 & NS & 0 & $1960(2.0)$ & $\begin{array}{c}\text { DgtV; } ; 2.2 \mathrm{E}- \\
9\end{array}$ \\
\hline & 17 & MI & 3.3 & $\mathrm{TV}$ & & & AVG & & & & & NS & & & 0.3 & 0.23 & 4 & 180 & 18 & NS & 0 & $1960(1.7)$ & $\begin{array}{c}\mathrm{Dg}+\mathrm{v} ; 2.2 \mathrm{E}- \\
9\end{array}$ \\
\hline & 18 & $\begin{array}{l}\text { IRR } \\
\end{array}$ & 3.3 & $\mathrm{TV}$ & & & AVG & & & & & NS & & & 0.3 & 0.23 & 2.5 & 54 & 12 & NS & 0 & $1960(1.0)$ & 0 \\
\hline & 19 & Best fit & 3.3 & TV & & & AVG & & & & & NS & & & 0.3 & 0.23 & 2.5 & 54 & 12 & NS & 0 & $1960(1.0)$ & $\begin{array}{c}\text { Dg+V;1.IIE- } \\
9\end{array}$ \\
\hline & 21 & $\mathrm{R}$ & 3.3 & TV & & & AVG & & & & & NS & & & 0.3 & 0.23 & 4 & 54 & 12 & NS & 0 & $1960(1.0)$ & $\begin{array}{c}\text { Dg+V;1.1IE- } \\
9\end{array}$ \\
\hline & 22 & D & 3.3 & $\mathrm{TV}$ & & & AVG & & & & & NS & & & 0.3 & 0.23 & 4 & 180 & 18 & NS & 0 & $1960(1.0)$ & $\begin{array}{c}\text { Dg+V;1.1IE- } \\
9\end{array}$ \\
\hline & 23 & MI & 3.3 & TV & & & AVG & & & & & NS & & & 0.3 & 0.23 & 4 & 54 & 12 & NS & 0 & $1950(1.0)$ & $\begin{array}{c}\mathrm{Dg}+\mathrm{V} ; 2.2 \mathrm{E}- \\
9\end{array}$ \\
\hline & R81e & K3 & $\begin{array}{c}\mathrm{O} \text {; rate of } \\
3.25\end{array}$ & $3.96(0)$ & 0 & M & $\mathrm{M}$ & $\mathrm{o}$ & $\mathrm{M} ;+3 \mathrm{~F}$ & $\begin{array}{c}\mathrm{M} ; \mathrm{VR}, 1 \text { to } \\
1 / 4\end{array}$ & $\begin{array}{c}\mathrm{M} ; \mathrm{VR}, 1 \text { to } \\
1 / 4\end{array}$ & $\mathrm{M} ; 1 / 4$ & $\mathrm{M} ; 1 / 4$ & $\mathrm{M} ; 1 / 4$ & \begin{tabular}{|c|}
$0.3 ;$ also \\
tested 0.35 \\
and 14 \\
14 \\
\end{tabular} & ss & & & & Flow on & & & \\
\hline & R84e & $\mathrm{HA}$ & $\begin{array}{c}\text {; rate of } \\
3.25\end{array}$ & $3.96(0)$ & $\mathrm{O} ;+0.75 \mathrm{HA}$ & $\mathrm{M} ;+0.75 \mathrm{H}$ & $\mathrm{A} \mid \mathrm{M} ;+0.75 \mathrm{HA}$ & $\mathrm{O} ;+0.75 \mathrm{HA}$ & $\begin{array}{l}\mathrm{M} ;+3 \mathrm{~F}, \\
0.75 \mathrm{HA}\end{array}$ & $\begin{array}{c}\mathrm{M} ; \mathrm{VR}, 1 \text { to } \\
1 / 4\end{array}$ & $\begin{array}{c}\mathrm{M} ; \mathrm{VR}, 1 \text { to } \\
1 / 4\end{array}$ & $\mathrm{M} ; 1 / 4$ & $\mathrm{M} ; 1 / 4$ & M; $1 / 4$ & 0.3 & ss & & & & Flow on & & & \\
\hline & $\begin{array}{c}\text { r91 (same as } \\
\text { rbw95e) }\end{array}$ & K2 & $\begin{array}{c}\mathrm{O} ; \text { rate of } \\
3.25 \\
\end{array}$ & $3.96(0)$ & o & $\begin{array}{l}\mathrm{M} ;+\mathrm{mz} \text { at } \\
86 \mathrm{ft} / \mathrm{d}\end{array}$ & M & o & $\mathrm{M} ;+3 \mathrm{~F}$ & $\begin{array}{c}\mathrm{M} ; \mathrm{VR}, 1 / 2 \\
\text { to } 1 / 8\end{array}$ & $\begin{array}{c}\mathrm{M} ; \mathrm{VR}, 1 / 2 \\
\text { to } 1 / 8\end{array}$ & $\mathrm{M} ; 1 / 4$ & $\mathrm{M} ; 1 / 4$ & $\mathrm{M} ; 1 / 4$ & \begin{tabular}{|c}
$0.3 ;$ also \\
tested 0.35 \\
for 12 and 14 \\
\end{tabular} & ss & & & & Flow on & & & \\
\hline & $\mathrm{r} 92$ & $\mathrm{VK} 1,2,3$ & $\begin{array}{c}\mathrm{O} \text {; rate of } \\
3.25\end{array}$ & $3.96(0)$ & o & $\begin{array}{l}\mathrm{M} ;+\mathrm{mz} \text { at } \\
86 \mathrm{ft} / \mathrm{d}\end{array}$ & M & o & $\mathrm{M} ;+3 \mathrm{~F}$ & $\begin{array}{c}\mathrm{M} ; \mathrm{VR}, 1 / 5 \\
\text { to } 1 / 20 \\
\end{array}$ & $\begin{array}{c}\text { M; VR, } 1 / 5 \\
\text { to } 1 / 20 \\
\end{array}$ & $\mathrm{M} ; 1 / 4$ & $\mathrm{M} ; 1 / 4$ & M; $1 / 4$ & \begin{tabular}{|c}
$0.3 ;$ also \\
tested 0.35 \\
for 12 and 14 \\
\end{tabular} & ss & & & & Flow on & & & \\
\hline & $\mathrm{r} 93$ & VK1 $1,2,3$ & $\begin{array}{c}\mathrm{O} \text {; rate of } \\
3.25 \\
\end{array}$ & $3.96(0)$ & o & \begin{tabular}{|l}
$\mathrm{M} ;+\mathrm{mz}$ at \\
$86 \mathrm{ft} / \mathrm{d}$
\end{tabular} & M & o & $\mathrm{M} ;+3 \mathrm{~F}$ & $\begin{array}{c}\mathrm{M} ; \mathrm{VR}, 1 / 5 \\
\text { to } 1 / 20 \\
\end{array}$ & $\begin{array}{c}\text { M; VR, } 1 / 5 \\
\text { to } 1 / 20 \\
\end{array}$ & M; $1 / 20$ & M; $1 / 4$ & $\mathrm{M} ; 1 / 4$ & \begin{tabular}{|c}
$0.3 ;$ also \\
tested 0.35 \\
for 12 and 14 \\
\end{tabular} & ss & & & & Flow on & & & \\
\hline 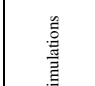 & $\begin{array}{c}\text { r120 (same } \\
\text { as rl100e) }\end{array}$ & BASE & $\begin{array}{c}\mathrm{O} ; \text { rate of } \\
3.25 \\
\end{array}$ & $3.96(0)$ & o & $\begin{array}{l}\mathrm{M} ;+\mathrm{mz} \text { at } \\
86 \mathrm{ft} / \mathrm{d}\end{array}$ & M & o & $\mathrm{M}$ & $\begin{array}{c}\mathrm{M} ; \mathrm{VR}, 1 / 2 \\
\text { to } 1 / 8\end{array}$ & $\begin{array}{c}\mathrm{M} ; \mathrm{VR}, 1 / 2 \\
\text { to } 1 / 8\end{array}$ & $\mathrm{M} ; 1 / 4$ & M; $1 / 4$ & $\mathrm{M} ; 1 / 4$ & \begin{tabular}{|c|c}
$0.3 ;$ a lso \\
tested 0.35 \\
for 12 and 14 \\
\end{tabular} & ss & & & & Flow on & & & \\
\hline 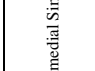 & R85e & $\mathrm{K} 2$ & $\begin{array}{c}\mathrm{O} ; \text { rate of } \\
3.25\end{array}$ & $3.96(0)$ & 0 & $\begin{array}{l}\mathrm{M} ;+\mathrm{mz} \text { at } \\
150 \mathrm{ft} / \mathrm{d}\end{array}$ & M & o & $\mathrm{M} ;+3 \mathrm{~F}$ & \begin{tabular}{|c|}
$\mathrm{M} ; \mathrm{VR}, 1$ to \\
$1 / 4$
\end{tabular} & $\begin{array}{c}\mathrm{M} ; \mathrm{VR}, 1 / 2 \\
\text { to } 1 / 8 \\
\end{array}$ & $\mathrm{M} ; 1 / 4$ & $\mathrm{M} ; 1 / 4$ & $\mathrm{M} ; 1 / 4$ & 0.3 & ss & $\begin{array}{c}\text { 2i in, } 13,15 ; \\
2.5 \text { in } \\
14 \\
14\end{array}$ & 54 & 12 & 1.2 & $4.57 \mathrm{mFg}$ & No & $\mathrm{V} ; 6 \mathrm{e}-13$ \\
\hline 离 & R86e & $\mathrm{HA}, \mathrm{K} 2$ & $\begin{array}{c}\mathrm{O} \text {; rate of } \\
3.25 \\
\end{array}$ & $3.96(0)$ & $\mathrm{O} ;+0.5 \mathrm{HA}$ & $\begin{array}{l}\mathrm{M} ;+\mathrm{mz} \text { at } \\
100 \mathrm{ft} / \mathrm{d}, \\
0.5 \mathrm{HA}\end{array}$ & $\mathrm{M} ;+0.5 \mathrm{HA}$ & $\mathrm{O} ;+0.5 \mathrm{HA}$ & $\begin{array}{l}\mathrm{M} ;+3 \mathrm{~F}, \\
0.5 \mathrm{HA}\end{array}$ & $\begin{array}{c}\mathrm{M} ; \mathrm{VR}, 1 \text { to } \\
1 / 4\end{array}$ & $\begin{array}{c}\mathrm{M} ; \mathrm{VR}, 1 / 2 \\
\text { to } 1 / 8\end{array}$ & $\mathrm{M} ; 1 / 4$ & M; $1 / 4$ & $\mathrm{M} ; 1 / 4$ & 0.3 & ss & $\begin{array}{c}2 \text { in } 11,1,1,15 ; \\
2.5 \text { i } 12 \text { and } \\
14\end{array}$ & 54 & 12 & 1.2 & $4.57 \mathrm{mFg}$ & No & $\mathrm{V} ; 6 \mathrm{e}-12$ \\
\hline & R87e & $R$ & $\begin{array}{c}\mathrm{O} ; \text { rate of } \\
3.25\end{array}$ & $3.96(0)$ & $\mathrm{O} ;+0.5 \mathrm{HA}$ & $\begin{array}{l}\mathrm{M} ;+\mathrm{mz} \text { at } \\
100 \mathrm{ft} / \mathrm{d}, \\
0.5 \mathrm{HA}\end{array}$ & $\mathrm{M} ;+0.5 \mathrm{HA}$ & $0 ;+0.5 \mathrm{HA}$ & $\begin{array}{l}\mathrm{M} ;+3 \mathrm{~F}, \\
0.5 \mathrm{HA}\end{array}$ & $\begin{array}{c}\mathrm{M} ; \mathrm{VR}, 1 \text { to } \\
1 / 4\end{array}$ & $\begin{array}{c}\mathrm{M} ; \mathrm{VR}, 1 / 2 \\
\text { to } 1 / 8\end{array}$ & $\mathrm{M} ; 1 / 4$ & $\mathrm{M} ; 1 / 4$ & $\mathrm{M} ; 1 / 4$ & 0.3 & SS & $\begin{array}{c}\begin{array}{c}2 \text { in } 11,13,15 ; \\
2.5 \text { in } 12,3 \text { in } \\
14\end{array} \\
\end{array}$ & 54 & 12 & 1.2 & $4.57 \mathrm{mFg}$ & No & $\mathrm{V} ; 6 \mathrm{e}-12$ \\
\hline
\end{tabular}




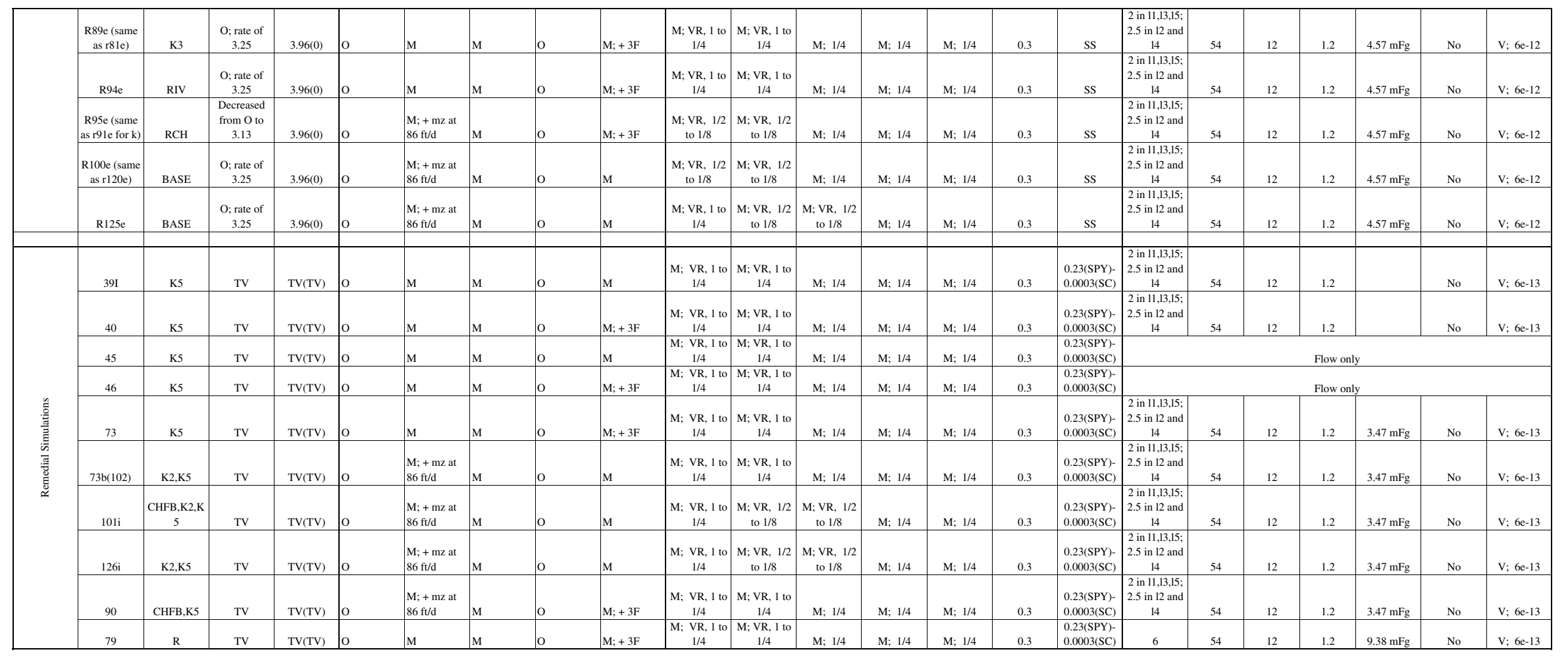




\section{Appendix 4}

a. Summary of model-computed ages from discrete particles backward tracked from screen interval layer(s), steady-state simulation of 1995-98 conditions, Milford-Souhegan glacial-drift aquifer, Milford, N.H.

b. Summary of model-computed ages from discrete particles backward tracked from sample intake layer, steady-state simulation of 1995-98 conditions, Milford-Souhegan glacial-drift aquifer, Milford, N.H. 
[All ages in years since water particle entered the ground-water system; Nonuniform porosity = porosity 0.3 in layers 1,3 , and 5 , and 0.35 in layers 2 and 4 ]

\begin{tabular}{|c|c|c|c|c|c|c|c|c|c|c|c|c|c|c|c|c|c|c|c|c|c|c|}
\hline \multirow{2}{*}{ Well } & \multirow{2}{*}{$\begin{array}{c}\begin{array}{c}\text { Apparent } \\
\text { ages }\end{array} \\
\text {. }\end{array}$} & \multicolumn{3}{|c|}{$\begin{array}{l}\text { Uniform porosity }(0.3) \\
\text { Model run } 81\end{array}$} & \multicolumn{3}{|c|}{$\begin{array}{l}\text { Nonuniform porosity } \\
\text { Model run } 81\end{array}$} & \multicolumn{3}{|c|}{$\begin{array}{l}\text { Nonuniform porosity } \\
\text { Model run } 91\end{array}$} & \multicolumn{3}{|c|}{ 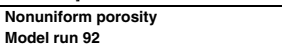 } & \multicolumn{3}{|c|}{$\begin{array}{l}\text { Nonunitiorm porosity } \\
\text { Model run } 93\end{array}$} & \multicolumn{3}{|c|}{$\begin{array}{l}\text { Nonunitorm porosity } \\
\text { Model run } 120\end{array}$} & \multicolumn{3}{|c|}{$\begin{array}{l}\text { Nonunifiorm porosity } \\
\text { Moded run } 125\end{array}$} \\
\hline & & Minimum & Maximum & Mean & Minimum & Maximum & Mean & Minimum & Maximum & Mean & Minimum & Maximum & Mean & Minimum & Maximum & Mean & Minimum & Maximum & Mean & Minimum & Maximum & Mean \\
\hline B95-3 & 2.69 & 0.19 & 1.13 & 0.51 & 0.21 & 1.28 & 0.56 & 0.30 & 1.52 & 0.65 & 0.32 & 1.94 & 0.77 & 0.33 & 1.88 & 0.76 & 1.11 & 1.19 & 1.16 & 1.10 & 1.20 & 1.16 \\
\hline & 0.92 & 0.32 & 12.24 & 5.04 & 0.37 & 12.28 & 5.09 & 0.77 & 12.44 & 5.13 & 0.69 & 12.29 & 4.43 & 0.69 & 12.31 & 5.11 & 1.32 & & & & 1.78 & 1.57 \\
\hline B95-8 & 4.9 & 0.88 & 10.66 & 1.42 & 0.97 & 10.76 & 1.53 & 1.55 & 10.38 & 2.17 & 1.49 & 6.62 & 2.38 & 1.51 & 9.18 & 2.8 & 2.1 & 11.03 & & & 11.48 & 2.99 \\
\hline$N-1 \mid$ & 2.37 & & 1.70 & 1.19 & 0.69 & 1.8 & 1.30 & 0.72 & 2.04 & & 0.71 & 1.9 & 1.4 & 0.7 & 1.9 & & 1.3 & & 2.1 & & 2.72 & 2.14 \\
\hline$M W-16 C$ & 5.94 & 1.69 & 23.41 & 8.16 & 1.81 & 23.73 & 8.44 & 1.71 & 23.44 & 8.48 & 1.71 & 20.35 & 8.30 & 1.70 & 23.86 & 10.23 & 2.32 & 36.90 & 14.19 & 2.33 & 31.61 & 13.19 \\
\hline
\end{tabular}

Appendix 4b. Summary of model-computed ages from discrete particles backward tracked from sample intake layer, steady-state simulation of 1995-98 conditions, Milford-Souhegan Glacial-Drift aquifer, Milford, N.H

[All ages in years since water particle entered the ground-water system; Nonuniform porosity = porosity 0.3 in layers 1,3, and 5 , and 0.35 in layers 2 and 4 ]

\begin{tabular}{|c|c|c|c|c|c|c|c|c|c|c|c|c|c|c|c|c|c|c|c|c|c|c|}
\hline \multirow{2}{*}{ well } & \multirow{2}{*}{$\begin{array}{c}\text { Apparent } \\
\text { ages }\end{array}$} & \multicolumn{3}{|c|}{$\begin{array}{l}\text { Uniform porosity (0.3) } \\
\text { Model run } 81\end{array}$} & \multicolumn{3}{|c|}{$\begin{array}{l}\text { Nonuniform porosity } \\
\text { Model run } 81\end{array}$} & \multicolumn{3}{|c|}{$\begin{array}{l}\text { Nonuniform porosity } \\
\text { Model run } 91\end{array}$} & \multicolumn{3}{|c|}{$\begin{array}{l}\text { Nonuniform porosity } \\
\text { Model run } 92\end{array}$} & \multicolumn{3}{|c|}{$\begin{array}{l}\text { Nonuniform porosity } \\
\text { Model run } 3\end{array}$} & \multicolumn{3}{|c|}{$\begin{array}{l}\text { Nonuniform porosity } \\
\text { Model run } 120\end{array}$} & \multicolumn{3}{|c|}{$\begin{array}{l}\text { Nonuniform porosity } \\
\text { Model run } 125\end{array}$} \\
\hline & & Minimum & Maximum & Mean & Minimum & Maximum & Mean & Minimum & Maximum & Mean & $\begin{array}{l}\text { Minimum } \\
\text { Minum }\end{array}$ & Maximum & Mean & Minimum & Maximum & Mean & Minimum & Maximum & Mean & Minimum & Maximum & Mean \\
\hline 95-3 & 2.69 & 0.44 & 1.13 & 0.74 & 0.47 & 1.28 & 0.83 & 0.50 & 1.52 & 0.92 & 0.58 & 1.94 & 1.13 & 0.58 & 1.88 & 1.13 & 1.26 & 2.36 & 1.68 & 1.25 & 2.32 & 1.66 \\
\hline $395-6$ & 0.92 & 6.91 & 12.24 & 9.68 & 6.96 & 12.28 & 9.72 & 2.55 & 12.44 & 9.23 & 2.04 & 12.29 & 7.87 & 2.05 & 12.31 & 7.90 & 3.04 & 13.59 & 10.19 & 3.26 & 13.62 & 10.31 \\
\hline $395-8$ & 4.9 & 0.88 & 10.66 & 1.42 & 0.97 & 10.76 & 1.53 & 1.55 & 10.38 & 2.17 & 1.49 & 6.62 & 2.38 & 1.51 & 9.18 & & 2.12 & 11.03 & 2.73 & 2.14 & 11.48 & 2.99 \\
\hline & 2.37 & 0.68 & 1.16 & 0.94 & 0.69 & 1.3 & 1.03 & 0.72 & 1.61 & 1.0 & 0.71 & & 1.0 & 0.7 & 1.4 & & 1.3 & & & 1.3 & 2.43 & 1.75 \\
\hline MW-16C & 5.94 & 1.69 & 2.96 & 2.17 & 1.81 & 3.39 & 2.42 & 1.71 & 4.02 & 2.76 & 1.71 & 4.06 & 2.63 & 1.70 & 4.13 & 2.67 & 2.32 & 4.70 & 3.37 & 2.33 & 4.74 & 3.42 \\
\hline
\end{tabular}


Manuscript approved for publication, August 13, 2004.

Prepared by the New Hampshire-Vermont District Publications Unit—Debra H. Foster, Anita Cotton, and Ann Marie Squillacci

For more information concerning the research in this report, contact Brian Mrazik, District Chief

U.S. Geological Survey

361 Commerce Way

Pembroke, NH 03275

Web site: http://nh.water.usgs.gov 